\begin{abstract}
UNIVERSIDADE DE SÃO PAULO
FACULDADE DE FILOSOFIA, LETRAS E CIÊNCIA HUMANAS

DEPARTAMENTO DE LETRAS CLÁSSICAS E VERNÁCULAS

PROGRAMA DE PÓS-GRADUAÇÃO EM LITERATURA BRASILEIRA
\end{abstract}

CLEITON OLIVEIRA DA SILVA

Regionalismo e fragmentação na experiência Barravento

- estudo de assimilações e análise de personagens -

Versão Corrigida

São Paulo

2020 


\title{
Regionalismo e fragmentação na experiência Barravento - estudo de assimilações e análise de personagens -
}

\author{
Versão Corrigida
}

Dissertação de Mestrado apresentada ao Programa de PósGraduação em Literatura Brasileira do Departamento de Letras Clássicas e Vernáculas da Faculdade de Filosofia Letras e Ciências Humanas da Universidade de São Paulo, como parte dos requisitos para obtenção do título de Mestre em Literatura Brasileira.

Orientador: Prof. Dr. Ivan Francisco Marques

São Paulo 
Autorizo a reprodução e divulgação total ou parcial deste trabalho, por qualquer meio convencional ou eletrônico, para fins de estudo e pesquisa, desde que citada a fonte.

Catalogação na Publicação Serviço de Biblioteca e Documentação

Faculdade de Filosofia, Letras e Ciências Humanas da Universidade de São Paulo

Silva, Cleiton Oliveira da
Regionalismo e fragmentação na experiência Barravento: estudo de assimilações e análise de personagens / Cleiton Oliveira da Silva ; orientador Ivan Francisco Marques. - São Paulo, 2020. $164 \mathrm{f}$.

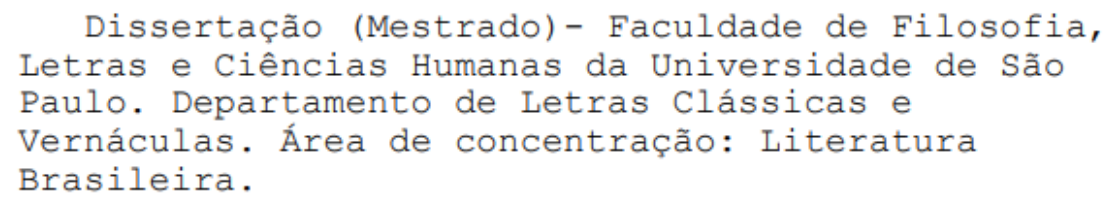

1. cinema brasileiro. 2. literatura brasileira. 3. Glauber Rocha. 4. regionalismo. 5. Barravento. I. Marques, Ivan Francisco, orient. II. Título. 


\section{ENTREGA DO EXEMPLAR CORRIGIDO DA \\ DISSERTACÃO/TESE}

\section{Termo de Ciência e Concordância do (a) orientador (a)}

Nome do (a) aluno (a): Cleiton Oliveira da Silva

Data da defesa: $21 / 09 / 2020$

Nome do Prof. (a) orientador (a): Ivan Francisco Marques

Nos termos da legislação vigente, declaro ESTAR CIENTE do conteúdo deste EXEMPLAR CORRIGIDO elaborado em atenção às sugestões dos membros da comissão Julgadora na sessão de defesa do trabalho, manifestando-me plenamente favorável ao seu encaminhamento e publicação no Portal Digital de Teses da USP.

São Paulo, 18/01/2021

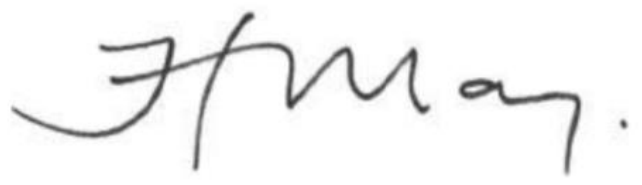


À ancestralidade.

Ao vô Zeca que acendeu a vela de Nossa Senhora das Candeias e foi para o mistério. Ao vô Eduardo e à vó Silvia que foram meus primeiros caboclos a partir.

À vó Emília que está sob o sol.

Aos meus bisavós, Tonho Beca e Ana do Tabuleiro. A sua bença. 


\section{Agradecimentos}

Ao professor Ivan Marques, por sua orientação generosa e suas leituras atentas, não apenas durante o mestrado, mas desde a graduação.

Ao Daniel Zeppo, meu companheiro da vida, que coloca beleza em tudo e viu nascer esta pesquisa antes mesmo de ser uma ideia, e acreditou sobretudo (ouvindo talvez mais vezes do que gostaria "Nanã ke um já sitó, Alodê..." nesses últimos dois anos e meio).

À minha família, que está entre o sol do Piauí e a fuligem de São Bernardo, este trabalho no fundo é sobre eles: pai, mãe, o Binho, a Eva, e o recém-chegado Davi Yuri que "saltou por detrás do Farol".

Aos meus amigos preciosos: Os que estavam no começo de tudo, Flávio "Chiny” que ri tão gostoso, Bia que estava lendo $O$ estrangeiro, Caio que me falou sobre o cinema e "nadamos de braçada", o Carlitos que é o irmão de nariz vermelho.

Lilian Akemi que mudou tudo, mudou tudo para sempre. Pati Anette que partiu nessa aventura comigo desde o tornozelo. Rafa Ireno que também leu a primeira ideia, amigo e parceiro no processo criativo periférico. Lu e Duda no chão de ferro, os pães de queijo, a Sabará de dentro. Fernanda Oliver, que faz nascer a flor no cacto, e Beyoncé, você sabe. Naiara Duarte que deu o toque final com seus pulsos suaves, Carô Gajevic dos chás, Gustavo Táriba dos memes e das broas, Fabi Garcia Coelho, meus xodós. - Fabi, é tudo azul e você sempre esteve lá quando eu cheguei.

"Paulete" Cordeiro que é sereia também, e rainha do mar. Juvêncio "Chuchu" que é Salvador e o primeiro caruru. Isabel, e a fumaça bonita que ela faz ao redor das palavras. Deco que trouxe de volta Orides Fontela, Marcia Fraguas que abriu as cartas ao mundo e leu o mapa astral.

A Ivan Grecov Filho, Exu que destrancou as portas fundamentais, e Aníbal David Salazar Beltrán, Iemanjá e suavidade, por nos terem levado generosamente para o Ilê Afrobrasileiro Lorecy. À Mãe Celina de Xangô e suas ervas poderosas.

À equipe da biblioteca e dos arquivos da Cinemateca Brasileira pelo acolhimento, a assistência. Por dias melhores para a Cinemateca.

Aos professores Ana Paula Pacheco e Ricardo Souza de Carvalho, pelo diálogo e as contribuições valiosas no exame de qualificação. E também aos professores Hélio de Seixas Guimarães e Viviana Bosi. E ao Juca Alves de Aguiar, que está em cada Pedro Nava, saudades sempre. 
Va subiendo la corriente

Con chinchorro y atarraya

La canoa de bareque

Para llegar a la playa

Habla con la luna

(El pescador) Habla con la playa

(El pescador) No tiene fortuna

Solo su atarraya

(“El Pescador", Totó la Momposina)

Sete cores tem o arco íris

Sete cores tem o trono de meu pai

Sete vezes eu quase caí

Mas na oitava eu não caio mais

Exu bebeu

Exu trabalhou

Exu nos deu a mão

Exu nos levantou

("Exu chega", Alessandra Leão / Luiz

Quiguiriçá / Trad. Umbanda) 


\section{Resumo}

Esta pesquisa trata do primeiro longa-metragem de Glauber Rocha, Barravento (1962) à luz das aproximações e distanciamentos que estabelece com dois precursores: a literatura regionalista de Jorge Amado e os documentários pioneiros de Alexandre Robatto Filho sobre a capoeira e a pesca de xaréu no litoral da Bahia. No processo de constituição de sua própria linguagem fílmica, o cineasta estreante tenta estabelecer uma perspectiva crítica da religião e um olhar antiimersivo para a cultura negra, mas produz uma obra rica em contradições internas. No intuito de observar mais em detalhe como essa complexidade de sentidos se projeta na estrutura do filme, propomos em um segundo momento uma análise de cada uma das personagens centrais.

Palavras-chave: Glauber Rocha, cinema brasileiro, regionalismo, cultura negra, Literatura e cinema. 


\begin{abstract}
This research examines Glauber Rocha's first feature film Barravento (1962) in the light of the approximations and distances it establishes with two precursors: Jorge Amado's regional literature, and Alexandre Robatto Filho's pioneering documentaries about capoeira and the xareu fishing on the coast of Bahia. In his own film language constitution process, the debutant filmmaker tries to establish a religion critical perspective and an anti-immersive look at the black culture. However, he produces a work rich in internal contradictions. In order to observe in more detail how this meaning complexity is projected in the film structure, we propose in a second moment an analysis of each of the main characters.
\end{abstract}

Keywords: Glauber Rocha, Brazilian cinema, regionalism, black culture, Literature and cinema. 


\section{Sumário}

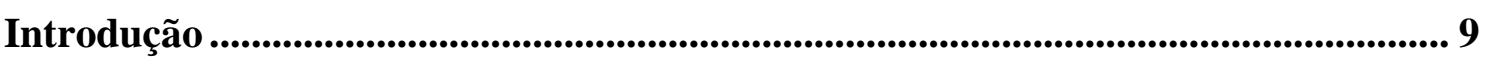

Capítulo 1. Barravento entre seus precursores ..................................................... 13

1.1. Uma fonte literária: Jorge Amado..................................................... 13

1.1.1. Dados do processo Barravento .............................................. 32

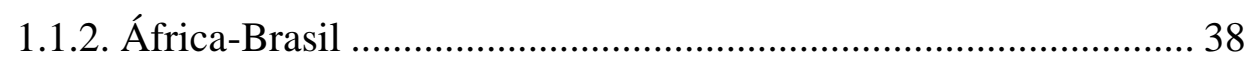

1.2. Uma fonte fílmica: Robatto Filho ...................................................... 44

Capítulo 2. Análise das personagens de Barravento ................................................... 65

2.1. Mestre, os trâmites da autoridade ..................................................... 65

2.2. Firmino, um malandro brechtiano........................................................ 77

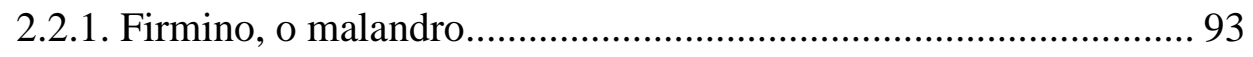

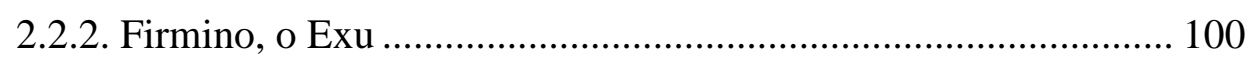

2.3. Aruan, a quebra do coité sagrado..................................................... 110

2.4. Naína e a melancolia dos mestiços ..................................................... 123

2.5. Cota, a imolação da mulher negra................................................... 137

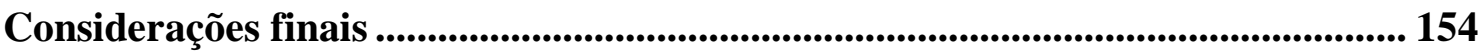

Referências bibliográficas........................................................................................................... 157 


\title{
Introdução
}

\author{
Quem é malandro não dá \\ vidinha boa a ninguém \\ ("Aviso aos navegantes" - \\ Paulo César Pinheiro/ Baden Powell)
}

Farol de Itapuã ao fundo, surge um malandro na bucólica vila de pescadores de xaréu. Firmino (Antonio Pitanga, então Sampaio) se envolveu com contrabando de cargas na cidade e vem buscar refúgio da polícia no seu vilarejo de origem. Ali, os homens do mar têm uma existência cíclica, entre a exaustiva pesca de arrastão e os preceitos do candomblé, sobretudo a reverência rigorosa a Iemanjá, Orixá ligada aos mares, mãe ciumenta de seus protegidos. A divindade é vingativa e furiosa, e o seu desagrado pode ter consequências graves, como o estouro do barravento, uma tempestade violenta que abala as ordens do mundo e indica mudança radical dos destinos.

No que diz respeito à coordenação do trabalho, a liderança fica a cargo do Mestre (Lídio Silva) que negocia o preço do peixe com os intermediários do proprietário das redes. Mas o acordo é extremamente desfavorável para os pescadores, que recebem proporcionalmente muito pouco do que pegam no mar.

Firmino está exultante no retorno, vangloria-se de sua vestimenta civilizada e de seu modo de vida "independente" na cidade mas, ao constatar a miséria de seus conterrâneos, começa a incitá-los ao abandono da fé cega na providência de Iemanjá e à mobilização contra o jugo econômico opressor. No entanto, seu discurso surte pouco efeito, ele não é figura de confiança pois guarda no passado relações conflituosas com seus conterrâneos. Fora expulso após atentar contra o preferido do vilarejo, Aruan (Aldo Teixeira), um jovem ingênuo que, além de estar sob a tutela do Mestre, inspira a admiração de todos por ser o escolhido de Iemanjá.

Mas essa posição privilegiada não é um ponto pacífico para o escolhido. Aruan se ressente do peso do preceito religioso, que lhe impõe a virgindade, e da responsabilidade de carregar a fé dos pescadores a despeito de seus próprios impulsos. Secretamente, ele nutre afetos pela única jovem branca da aldeia, a sorumbática Naína (Lucy de Carvalho), que vive preocupada com seu velho pai e foge das obrigações do candomblé, por receio de fazer o santo. 
No fundo, Aruan acredita no discurso de Firmino sobre a passividade dos homens, e talvez incitaria seus conterrâneos à resistência contra os desmandos externos, não fosse o tirânico conformismo do Mestre.

Assim, Firmino enxerga em Aruan ao mesmo tempo um obstáculo, por ele alicerçar a fé dos pescadores, e um vigor revolucionário adormecido, que poderia liderálos para a luta. Por isso, passa a mobilizar uma série de estratagemas apressados para atingir a sacralidade do jovem virgem: faz um ebó, fura a rede de pesca, e termina por incitar a sua própria amante, Cota (Luiza Maranhão), a seduzi-lo. Cota é, ela também, uma figura malquista na comunidade, devido a sua independência e liberalidade sexual ("eu me viro na hora que bem quero, a carne é minha e quem faz o preço sou eu”). O último dos estratagemas tem sucesso, Aruan perde sua virgindade, o barravento eclode e custa algumas vidas, dentre as quais, a da própria Cota.

No cúmulo da tensão, Aruan e Firmino entram em um último duelo, um jogo de capoeira que termina com a vitória do último e a desmoralização final do ex-predileto. Tendo cumprido sua missão, o malandro-Exu desaparece. Por fim, dessacralizado, sem mais valor diante dos seus, Aruan decide seguir a trilha aberta por Firmino e partir para a cidade, quem sabe consiga um trabalho e possa comprar uma rede, após o quê voltaria para se casar com Naína. A jovem segue o caminho oposto, e termina por fazer o santo, finalmente acatando o sistema de valores da comunidade, até porque deseja em alguma medida purgar o pecado de seu pretendente.

Barravento é o primeiro longa-metragem de Glauber Rocha, desenvolvido a partir de um argumento comprado de Luiz Paulino dos Santos (Um dia na rampa, 1959) quando o primeiro diretor desistiu do projeto em decorrência de conflitos durante a produção. Foi filmado em cerca de cinquenta dias no segundo semestre de 1960, com poucos recursos (3000 dólares, 6000 metros de película), ${ }^{1}$ na praia de Buraquinho, em Itapuã, na Bahia. Apesar da rapidez das filmagens, Glauber hesitou em trabalhar com o material e a montagem só foi feita oito meses depois, quando Nelson Pereira dos Santos se interessou pelos copiões. O filme estreou primeiramente fora do Brasil, no Festival Internacional de Cinema de Karlovy Vary, na antiga Tchecoslováquia, onde recebeu o prêmio Opera Prima.

STAM, Robert. Multiculturalismo tropical, um História Comparativa da raça na cultura e no cinema brasileiros. Trad. Fernando S. Vugman. São Paulo: Edusp, 2008. p.315. 
Trabalhando ativamente na crítica de imprensa até então, Glauber Rocha faz a estreia no cinema de grande circuito consolidando seu nome como um expoente do Cinema Novo, em um período de formação do movimento. A inovação da linguagem fílmica a partir da recusa da fórmula comercial, a abordagem dos temas sociais herdada em grande parte da literatura regionalista dos anos 1930 e, finalmente, a produção com poucos recursos se transformam na força estética do movimento, o que Glauber sintetiza anos mais tarde no manifesto "Uma estética da fome".

O objetivo desta pesquisa é fornecer elementos de análise e compreensão da obra tendo em vista a construção de uma linguagem fílmica inovadora pelo jovem cineasta, mas que dialoga profundamente com seus precursores: a tradição literária regionalista e o cinema documental que vinha sendo feito na Bahia até então. A dissertação se organiza em dois momentos:

No primeiro capítulo, a investigação do diálogo que Barravento abre com duas matrizes: a literatura regionalista litorânea de Jorge Amado e as experiências documentais de Alexandre Robatto Filho. Mais especificamente, as ressonâncias de obras como o romance Mar morto (1936) na composição dos elementos do enredo - o drama, os arquétipos do mundo praieiro, a representação da cultura popular -, mas também como Glauber abre uma perspectiva crítica ao rearranjá-los dentro da linguagem cinematográfica. Procuramos demonstrar também como, de forma análoga, o diretor absorve uma imagética presente nos documentários de pesca e capoeira de Alexandre Robatto Filho para radicalizá-la e colocar em questão o olhar museológico sobre a cultura negra.

O segundo capítulo é dedicado a uma análise detida das personagens do filme. O Mestre, Firmino, Aruan, Naína e Cota são estudados a partir de eventuais modificações que se acumulam nas diferentes versões do roteiro, de como as interações entre eles e os elementos expressivos do filme marcam sua função na evolução da trama, suas ambivalências, as verdades históricas atrás de suas motivações e seu modo de ação, e como, no horizonte das personagens há sempre o espectro da vida urbana, a possiblidade mais ou menos palpável do êxodo.

Para tanto, procuramos acessar os roteiros de Barravento e artigos de jornal que se encontram conservados na Cinemateca Brasileira, transcritos em partes ao longo do trabalho na medida em que uma observação mais detida de certos aspectos se fez necessária. A bibliografia escrita sobre e por Glauber Rocha, mas também sobre Bertolt Brecht, o Cinema Novo, a cultura baiana, o candomblé, a metropolização das cidades 
brasileiras no século XX, fornecem um importante substrato teórico. O método analítico que empregamos para os filmes é fortemente inspirado em Ismail Xavier e nos estudos da sua obra Sertão mar: Glauber Rocha e a estética da fome. ${ }^{2}$ A maneira como o estudioso observa em detalhe a articulação entre enredo, intenção e elementos estruturais do filme foi formadora e baliza todo este trabalho. 


\section{Capítulo 1. Barravento entre seus precursores}

\subsection{Uma fonte literária: Jorge Amado}

Jorge, tenho certeza de que conheço melhor sua obra do que você conhece a minha. Gostaria de um dia lhe prender num cinema, e lhe mostrar encarrilhado Barravento, Terra em transe, Deus e o Diabo, e o Dragão. Tem muito de você, de Zé Lins, de Rosa, de Villa-Lobos e Portinari. Nunca filmei romance seu, nem de ninguém. Mas roubei de vocês as pedras que vocês deixaram de herança para qualquer um: foi da síntese de Eisenstein com Mar morto, de Caymmi com Jorge de Lima, que nasceu Barravento. Você só viu, acho, o copião com o Heron. Deus e o Diabo não existiria sem cangaceiros (sic) e Pedra Bonita, sem Seara. Mas de você eu roubei a estrutura épica, de Brecht e dos artistas revolucionários. ${ }^{3}$

O trecho acima está em uma correspondência de Glauber Rocha enviada em março de 1978 a Jorge Amado. O autor da carta já é um cineasta consagrado nacional e internacionalmente, embora alvo de uma série de controvérsias com o meio intelectual brasileiro no retorno do exílio por conta de ideias políticas - no mínimo polêmicas - que vinha publicando. Aqui, prestes a lançar seu documentário Jorjamado no cinema (1979), passa em revista parte de sua primeira obra à luz de algumas de suas influências literárias e cinematográficas. É também um momento de estreia na literatura enquanto escritor, tendo em vista o lançamento de seu primeiro e único romance, Riverão sussuarana, no mesmo ano.

A presença de Jorge Amado no repertório intelectual de Glauber Rocha remonta aos seus anos de formação. Ainda em 1953, aos 14 anos, ele menciona em correspondência ao seu tio, entre outros assuntos, sua predileção pela literatura nacional regionalista em detrimento dos clássicos estrangeiros, com destaque para a obra de seu

\footnotetext{
ROCHA, Glauber. Cartas ao Mundo (org. Ivana Bentes). São Paulo: Companhia das Letras, 1997, p.634. Neste trecho aparece "cangaceiros" em letra minúscula e sem destaque, mas é provável que Glauber se refira ao último romance de Lins do Rego (1953). Em nota a organizadora explica que o original foi escrito de forma corrida e sem correção, o que justificaria algumas passagens estranhas e, no caso, a ausência de destaque.
} 
conterrâneo: "Li Terras do sem-fim, de Jorge Amado, e achei mais do que 'realista'. A sua linguagem poder-se-ia dizer quase imoral."4

A influência de Jorge Amado se faz sentir ao longo da carreira de Glauber, tanto pela amizade pessoal quanto na forma de uma certa tutoria intelectual de âmbito literário, como atesta a correspondência entre ambos. É importante lembrar que o escritor itabunense e seu círculo de companheiros, dentre os quais Carybé, Verger, Mário Cravo Júnior, Mirabeau Sampaio, Robatto Filho, Dorival Caymmi, entre outros, compõem um grupo de intelectuais sediados na capital baiana que contribui significativamente para a construção de uma imagem arquetípica da Bahia no âmbito da literatura e das artes visuais, sobretudo entre os anos 1930-1950.

Operando em vários campos da arte e do conhecimento, dentre os quais a pintura, a escultura, a etnofotografia, a sociologia, o documentário, a canção e a literatura, esses intelectuais oriundos das classes médias privilegiadas, alguns estrangeiros como Verger, Bastide, Gautherot et Carybé, desentranharam do seio da cultura popular baiana uma série de signos e matérias então pouco dignificadas pela tradição artística brasileira, sobretudo de matriz africana, e transpuseram-nas para o debate cultural e a pesquisa estética modernas.

Glauber Rocha é de uma geração um pouco posterior, mas cresce assimilando esse patrimônio imagético, tendo como catalisador intelectual o evento não pouco significativo de sua frequentação da recém-fundada Universidade de Salvador (1946). ${ }^{5}$ Sob o impulso do crescente espírito urbano-desenvolvimentista da República Populista, a universidade passou a propiciar à nova safra intelectual baiana um contato privilegiado, no meio acadêmico, com a vanguarda artística europeia do pós-guerra. Isso porque um grupo de intelectuais imigrantes, radicados sobretudo no sudeste do Brasil, vem compor os quadros de ensino nas mais diversas áreas a convite do então reitor, Edgard dos Santos.

Nesse grupo estiveram: a arquiteta italiana Lina Bo Bardi, responsável pela concepção do Museu de Arte Moderna; o maestro e compositor austríaco da vanguarda dodecafônica Hans-Joachim Koellreutter, produzindo os Seminários Livres de Música; o filósofo português Agostinho da Silva, fundador do CEAO (Centro de Estudos AfroOrientais); a bailarina polonesa Yanka Rudzka, na direção da Escola de Dança, e alguns

\footnotetext{
$4 \quad$ ROCHA, op. cit., p.79.

5 RISÉRIO, Antonio. Avant-garde na Bahia. São Paulo: Instituto Lina Bo e P.M. Bardi, 1995.
} 
brasileiros de formação internacional, como Eros Martim Gonçalves, que assumiu a Escola de Teatro.

A vanguarda europeia estava profundamente imbuída de uma atenção antropológica, e a Bahia, com a vivacidade de seu substrato cultural afro-brasileiro, insulada por décadas de estagnação econômica, representava uma fonte inesgotável de estudo, inspiração e reformulação estética. É por um espírito ao mesmo tempo neocosmopolita e pesquisador das matrizes culturais brasileiras que se deu, por exemplo, a criação do Centro de Estudos Afro-Orientais atuando no sentido de favorecer o intercâmbio cultural entre Brasil e África.

O experimentalismo vanguardista estava em busca da emanação de novas formas para além dos modelos do epicentro europeu e se inscrevia, mais amplamente, no que o teórico Frederic Jameson ${ }^{6}$ aponta como uma tendência terceiro-mundista da intelectualidade progressista ocidental a partir do processo de descolonização da África e da Revolução Cubana. Em busca de modelos político-culturais no chamado Terceiro Mundo, esses intelectuais abarcavam as experiências de "novas" categorias identitárias de gênero, de etnia, dos colonizados, marginalizados etc.

\footnotetext{
Os anos 60 foram, assim, a época em que todos esses "nativos" tornaram-se seres humanos, e isto tanto interna quanto externamente: aqueles internamente colonizados do Primeiro Mundo - as "minorias", os marginais, e as mulheres - não menos os súditos externos e os "nativos" oficiais desse mundo. ${ }^{7}$
}

Ao que parece, esse ambiente formador propiciou a Glauber Rocha o testemunho da confluência entre a pesquisa estética da vanguarda internacional, no ambiente acadêmico, e a cultura moderna brasileira, em uma perspectiva de assimilação e aprofundamento crítico. No que diz respeito à fonte nacional, a matéria antropológica baiana que desperta o interesse terceiro-mundista da vanguarda constitui, para Glauber e sua geração, um tipo de repertório orgânico que os regionalismos de Jorge Amado, Lins

\footnotetext{
6 JAMESON, Frederic. "Periodizando os anos 1960" in HOLLANDA, Heloísa Buarque de. (org). Pós-modernismo e política. Trad. César Brites e Maria Luiza Borges. Rio de Janeiro: Rocco, 1992.

$7 \quad$ Ibid., p.85.
} 
do Rego e Graciliano Ramos já vinham desenvolvendo com maior ou menor tensão desde os anos 1930.

Assim, estabelece-se no meio intelectual universitário de Salvador uma revitalização da dialética entre as novas estéticas internacionais e a tradição local, o cosmopolitismo da vanguarda e a cultura brasileira. Essa dialética também é alimentada pelo surgimento de intensas dinâmicas sociais nas funções da metrópole terceiromundista, que infla nos anos 1950, reforçando velhas clivagens econômicas que remontam à colonização.

Prova desse encontro é o interesse crítico pela literatura brasileira que Glauber exprime nos anos de formação como escritor e editor em duas revistas acadêmicas: Ângulos e Mapa. Na última, publica em 1957 um vasto estudo intitulado "Romance de José Lins do Rêgo". O ensaio não parece ter sido motivado meramente pela morte do escritor paraibano, que se deu no mesmo ano: Glauber declara no corpo do texto que o trabalho já estava pronto para publicação desde antes.

O jovem crítico acadêmico, sem ter feito ainda sua estreia no cinema, examina longamente o conjunto da obra de Lins do Rego e o coloca, em mais de um momento, em prisma com sua geração de regionalistas:

A terra e o homem, eis as constantes do romance nortista. Em Graciliano Ramos, Jorge Amado e José Lins do Rêgo, apontados pela crítica como a trindade máxima desse romance, encontram-se manifestadas três tendências diversas na captação e interpretação da realidade visada, caminhos que partem de um mesmo tema em direções contrárias, indo desde o aproveitamento e emprego literário da língua, até o domínio do elemento psicológico e documentação social. Realismo, romantismo e lirismo seriam fundamentalmente as características básicas e respectivas dos três romancistas. ${ }^{8}$

Glauber, enquanto crítico de literatura, está atento à maneira como a tríade regionalista recupera certas convenções da linguagem literária - realismo, romantismo e lirismo - para interpretar, cada qual ao seu estilo, uma instância do mundo não-ficcional:

8 ROCHA, Glauber. Mapa, 1957, p.61. apud REBECHI JUNIOR, Arlindo. Glauber Rocha, ensaísta do Brasil. Tese (Doutorado em Literatura Brasileira) - Faculdade de Filosofia, Letras e Ciências Humanas, Universidade de São Paulo, São Paulo, 2011, p.313-314. 
a experiência do homem brasileiro provinciano, enraizado física e psicologicamente em redutos regionais que vão sendo historicamente negligenciados pelo projeto econômico nacional, sobretudo no nordeste.

Em pleno período de expansão massiva da teia urbana e do convívio com o neocosmopolitismo intelectual da vanguarda, o olhar crítico de Glauber Rocha não deixa de se voltar para a literatura que tratou do homem não-urbano. A identificação com o Jorge Amado, Graciliano e Lins do Rego, que remonta aos anos de juventude, atravessa então a fase acadêmica como crítico e chega ao seu primeiro cinema, prova disso é a forte presença do componente regionalista nos longas Barravento e Deus e o diabo na terra do sol.

Chegou Nelson para filmar Vidas secas e recebeu apoio de Juracy. Cineastas como navegantes em busca do Eldorado no sertão ou no mar. Minas de Estética na Bahia. Jorge Amado tinha descoberto veio gordo. Eu era a projeção cinematográfica de Jorge. ${ }^{9}$

Na transposição dos elementos da convenção literária para a convenção fílmica, que ressonâncias Barravento exprime com relação à obra de Jorge Amado? Interessa-nos sondar neste primeiro item que tipo de assimilação crítica do regionalismo está em jogo no primeiro filme de Glauber, tendo em vista uma tensão fundamental: entre a filiação à literatura regionalista de matriz litorânea, que remonta aos anos 1930, e as questões críticas da sua contemporaneidade. Para tanto, procuramos analisar o filme à luz da obra de Jorge Amado que, segundo o próprio diretor, é sintetizada em Barravento: o romance Mar morto.

Mar morto, o quinto livro de Jorge Amado, foi publicado em 1936. Alfredo Bosi, na História concisa da literatura brasileira, atribui esse romance a um segundo momento da obra do autor baiano, quando, após consolidada a apropriação estética do "romance proletário", Amado incide nos "depoimentos líricos, isto é, sentimentais, espraiados em torno de rixas e amores marinhos". ${ }^{10}$

9 ROCHA, Glauber. Revisão crítica do cinema brasileiro. São Paulo: Cosac \& Naify, 2003, p.333.

10 BOSI, Alfredo. História concisa da literatura brasileira. São Paulo: Cultrix, 2006, p.406. 
O enredo se desenvolve no cais da Bahia em torno da vida do pescador Guma, deixado pelo pai, mal afamado, e pela mãe, uma prostituta, aos cuidados do tio saveirista, o velho Francisco. Desde a sua infância, o jovem carismático já demonstra grande vocação para o trabalho no mar e chega a realizar feitos heroicos que despertam a admiração da comunidade. Um desses feitos leva-o a conhecer Lívia, uma jovem da cidade alta que vive com os tios comerciantes. Embora hesite em trazê-la para junto de si, para as agruras da vida no cais, onde as mulheres se tornam jovens viúvas por conta das frequentes mortes de maridos e filhos no mar, Guma cede à paixão e rapta a jovem.

Algum tempo se passa, nasce um filho. Durante uma crise, a miséria grassa no cais e o pescador se vê obrigado a trabalhar no contrabando de tecidos comandado por comerciantes turcos, a despeito de seus próprios princípios morais e da preocupação de sua esposa. Uma greve eclode e os estivadores e saveiristas conseguem o aumento dos seus ordenados, estabilizando a crise. Mas pouco depois, Guma acaba morrendo afogado durante um último contrabando, não sem antes salvar heroicamente a tripulação de seu saveiro. A despeito das expectativas, Lívia decide não voltar para a cidade alta e se converter definitivamente à vida do cais, à frente do barco deixado pelo seu marido.

Essa trama está organizada em três blocos de extensão assimétrica:

a) "Iemanjá, Dona dos mares e dos saveiros", que abre e fecha em torno do nascimento e consolidação dos amores de Guma e Lívia. Nesse trecho são apresentadas as personagens centrais a partir de um flashback que reconstitui a vida do protagonista, da sua infância à maturidade sexual. A história de Guma é um retrato trágico-lírico da vida dos saveiristas no cais da Bahia, com uma ênfase nas suas relações com o sagrado, na devoção a Iemanjá.

b) "O Paquete Voador" é um bloco bastante heterogêneo: envolve desde episódios mais melodramáticos, como a dupla infidelidade de Guma com relação a Lívia e seu melhor amigo, Rufino, até episódios sinistros, de tragédia no mar, como um naufrágio nas imediações do cais que vitimou crianças e adultos. Por um lado, há uma crise de consciência pessoal do protagonista, por outro, o ciclo incontornável da catástrofe que ronda a vida coletiva no mar. A ênfase fica sendo a presença da morte e a miséria como ameaças constantes, em contraste com o signo de vida que é o nascimento do filho. Ao fim desse bloco, contudo, o protagonista morre afogado.

c) "Mar morto", que explica o título do livro, acompanha a transformação final de Lívia, que após um luto quase impassível se transforma em uma mulher 
do mar, o que se configura aos olhos dos saveiristas em uma cena épica onde a jovem é vista como a própria encarnação de Iemanjá.

Apesar de o romance de Jorge Amado possuir um enredo complexo com uma maior profusão de personagens, há uma série de semelhanças na estrutura dramática de Barravento e Mar morto que vão desde o aproveitamento de certos tipos sociais até a função de alguns personagens no estabelecimento das relações intradiegéticas.

Em linhas gerais, no centro de ambas as narrativas está a figura do jovem carismático, algo ingênuo, benquisto em seu meio social. Tanto Guma quanto Aruan são responsáveis por feitos memoráveis instigados por princípios morais e respeito a uma espécie de código comum de honra da comunidade. Despertando a reverência de seus pares, Guma enfrenta uma tempestade para salvar um navio à deriva. Aruan, quando a rede dos pescadores é recolhida, passa a noite no mar em uma jangada para provar que é filho de Iemanjá.

Em torno desses protagonistas há um triângulo amoroso que opõe, segundo um certo lugar-comum da cultura brasileira, a castidade e o amor subserviente da mulher branco-mestiça (Naína-Lívia) ao amor libertino e imoral da mulher negra (CotaEsmeralda). A realização do segundo conduz, irremediavelmente, à catástrofe que é literal e cósmica, com a morte violenta da mulher negra, que deve "pagar o preço" por suas ações imorais, e a ascensão espiritual da mulher branca.

Assim, no polo da malícia, a Esmeralda de Jorge Amado, inculpada por ter seduzido o melhor amigo de seu amante, Rufino, morre assassinada por ele próprio, e é jogada ao mar para ser devorada por tubarões; em Barravento, por sua vez, Cota enlouquece e morre afogada na sinistra Lagoa de Abaeté após ter sido peça-chave no plano de seu amante Firmino, sem que ninguém lamente seu destino. No polo da castidade, a Lívia de Mar morto cumpre seu luto e se converte à vida marítima, em cena final de grande dramaticidade onde é contemplada pelos marítimos como a própria Iemanjá, à frente do barco de seu falecido amante. Em Barravento, Naína aceita fazer o santo e fecha o ciclo trágico da sua descendência, com a promessa de poder purgar também Aruan, por conseguinte, passa a integrar legitimamente o sistema de valores do vilarejo.

Ambas as narrativas estão estruturalmente alicerçadas na representação de núcleos sociais negros que vivenciam positivamente sua cultura e religiosidade. Entretanto, se por um lado rompem com certos pressupostos do "decorativo" e do 
"pitoresco" comumente atribuídos a essa cultura por um discurso preconceituoso e dominante, por outro, resvalam eventualmente em um sistema de arquétipos comuns, conservador de outra forma: o complexo da representação da sexualidade na mulher branca e na mulher negra. Lívia e Naína, ainda que hesitem em aderir ao modelo de cultura local, terminam incluídas de maneira exultante; o mesmo sistema é expulsivo para Esmeralda e Cota que estavam organicamente ligadas a ele, mas que agiam com independência moral e liberdade sexual.

Outro dado da filiação de Barravento a Mar morto, ou mais amplamente à ficção regionalista, é a tendência a um certo ensaísmo social, isto é, o aproveitamento de tipos populares para denunciar mazelas econômicas e condições de exploração, com diferenças evidentes no seu nível de tensão e importância estrutural para o enredo. Nas duas obras, um dos meios pelos quais a crítica social penetra o enredo é o discurso de certas personagens

Por exemplo, no romance de Jorge Amado conhecemos apenas duas figuras letradas no cais: Dona Dulce e Doutor Rodrigo, uma professora de ensino primário e um médico, poeta nas horas vagas, ambos oriundos da classe média da cidade alta de Salvador. Eles abdicam (compelidos pela decadência familiar, no caso de Dona Dulce) de suas possibilidades de conforto material na cidade alta para se devotar à comunidade pobre do cais da Bahia. Agem como observadores externos e politicamente conscientes, mas, de certa forma, paternalistas e resignados. Observe-se a cena a seguir, que se desenrola no cortejo do casamento de Guma e Lívia:

No fim do cortejo, D. Dulce conversava com Dr. Rodrigo. Vinham de braço dado como noivos, mas ela já estava um pouco curva e via com dificuldade, apesar dos óculos. Ele pitava o cachimbo.

- Mundinho morreu... - disse ele.

- Pobre da mãe...

- Eu fiz tudo. Mas não havia possibilidade de salvá-lo aqui. Falta de higiene, de toda espécie de recurso...

- Ele esteve na escola. Era um bom aluno. Iria longe... De qualquer maneira, não havia de demorar lá. Essa gente não pode, doutor. Precisam dos filhos para ajudar a ganhar o pão. Muitos deles são inteligentes que faz gosto... Guma mesmo...

- Há muitos anos que a senhora está aqui, não é, D. Dulce?

Ela corou um pouco e respondeu: 
- Faz muito tempo, sim. É muito triste...

Dr. Rodrigo ficou sem saber se ela se referia à sua própria história ou à vida do cais. Ela ia curva e a chuva prateava seu cabelo.

- Por vezes eu fico pensando... Já podia sair daqui, arranjar uma cadeira melhor... Mas tenho pena dessa gente que gosta tanto de mim. No entanto eu não sei o que dizer a eles...

[...]

Então D. Dulce disse:

- Não é mais um milagre do Céu que eu espero. Já roguei muito aos santos e assim mesmo os homens e as crianças morreram. Mas eu tenho fé, sim. Tenho fé, Rodrigo, nesses homens. Uma coisa me diz que eles é que farão o milagre...

Dr. Rodrigo olhou para D. Dulce. Os olhos da professora eram bondosos e sorriam. O médico pensou nos seus versos fracassados, na sua ciência fracassada. [...] Dr. Rodrigo disse:

- Que milagre, Dulce? Que milagre?

Ela estava transfigurada, parecia uma santa. Os olhos doces corriam para o mar. Uma criança veio e ela descansou a mão descarnada na sua cabeça:

- Um milagre, sim.

A criança ia agora com eles na noite úmida que se aproximava. Dulce continuou a falar:

- Você nunca imaginou esse mar cheio de saveiros limpos, com marítimos bem alimentados, ganhando o que merecem, as esposas com o futuro garantido, os filhos na escola não durante seis meses, mas todo o tempo depois indo aqueles que têm vocação para as Faculdades? Já pensou em postos de salvamento nos rios, na boca da barra? Às vezes eu imagino o cais assim... ${ }^{11}$

O diálogo que se encena, embora trate da questão social, é permeado por um campo semântico de mistificação cristã, que começa na evocação da "fé”, passando pelo uso reiterado da palavra "milagre" e ganha materialidade na verdadeira transfiguração de Dona Dulce ao final. Se no princípio da cena o narrador a apresenta como uma velha recurvada e melancólica, logo adiante, ao falar sobre a possiblidade de mudança das

11 AMADO, Jorge. Mar morto. Rio de Janeiro: Record, 63 a ed., 1990, p.119-121. 
condições de vida do cais, Dona Dulce vai assumindo uma feição messiânica - a criança ao seu lado reforça essa imagem beatífica.

Diante dessa transfiguração, o Doutor se faz humilde, pensa no fracasso de sua ciência e de seu beletrismo. No âmbito da miséria coletiva do cais, o discurso da fé cristã, veiculado pela velha senhora oriunda das classes médias, parece sobrepujar o racionalismo do materialista, que é sorumbático e conformista: "Talvez só D. Dulce soubesse que ele fazia poemas sobre o mar, porque ele achava a sua poesia fraca demais para o motivo." 12

Momentos antes, o médico pergunta retoricamente se Dona Dulce estava há muito tempo no cais, ao que ela responde afirmativamente: "Sim. É muito triste". Segundo o narrador, Dr. Rodrigo fica sem saber se ela se refere ao cais ou a si mesma. Por aí depreendemos que a vida da velha professora se confunde com o cotidiano do cais, o que poderíamos definir em termos de tempo e de condição como: é antigo e é triste. Isso significa que a consciência da necessidade de mudança social em Dona Dulce é uma presença pacífica no meio da miséria, não açula os saveiristas, não incute neles algum desejo de ação, é interna e externa ao mesmo tempo - ela está lá mas suas ideias não produzem efeito porque estão condicionadas pelo mesmo fatalismo mistificante dos próprios canoeiros. Há um pacifismo em sua derrota, e um conformismo em sua paz beatificada.

De uma força política mais consequente na trama social do cais é a evocação da história de uma figura verídica, o Besouro Mangangá (1895-1924), na segunda metade do primeiro bloco. Após um episódio de fuga, quando tenta despistar a polícia ao salvar um colega ferido de uma rixa em Cachoeira, Guma aporta em Santo Amaro. Em um momento de introspecção, evoca a figura mítica do capoeirista Besouro nativo daquela cidade, símbolo estimado pelos homens do cais: "Besouro correu naquelas ruas, ali derramou sangue, esfaqueou, atirou, lutou capoeira, cantou sambas." ${ }^{13}$ No imaginário de Guma, o capoeirista se destaca positivamente como um rebelde contra a violência das forças de ordem e das oligarquias opressoras, resquícios tardios das estruturas coloniais, pelas quais foi violentamente atraiçoado.

No episódio, há uma busca de referência moral no mártir do passado. Guma está diante do dilema de casar-se ou não, engajar ou não o destino de Lívia na fatalidade

\begin{tabular}{ll}
\hline 12 & Ibid., p.94. \\
13 & Ibid., p.99.
\end{tabular}


irreversível da vida no cais. E há também, claro, uma tentativa de alinhamento entre o heroísmo de Besouro e o mais recente feito do jovem saveirista, que resgata um amigo perseguido por ter morto um jovem de família prestigiosa. Há uma oscilação da consciência do protagonista entre viver o amor romântico e seguir o rastro solitário do herói popular, mas sabemos que a decisão final recai sobre a realização do amor idealizado. Mais uma vez, a força de inspiração revolucionária não demove a subjetividade romântica.

Alguma mudança no vigor do elemento político ocorre em meados do segundo bloco do romance, quando a figura de Chico Tristeza volta ao cais. Este sim, integrante legítimo do povo do cais, desaparecera anos antes ao se engajar em um navio internacional de grande porte. Por conta dessa experiência "cosmopolita" conheceu a realidade social de diferentes países e evoca a condição colonial africana, com um episódio de resistência de um homem negro, Bagé, aos maus tratos físicos de um colono francês. Sua chegada é acompanhada com atenção pelos conterrâneos, especialmente por Guma que, segundo o narrador, sempre desejou se aventurar nos navios de grande curso:

- Lá pras bandas da África onde eu tive, meu povo, vida de negro é pior que vida de cachorro. Tive nas terras dos negros que agora são dos Franceses. Ali negro não vale nada, negro é só escravo de branco, apanha de chicote. E ali é terra deles...

- Calcule se não fosse...

Chico Tristeza olhou o aparteador:

- Nas terras deles eles não vale nada. Só vale branco, branco é tudo, pode tudo. Os negros trabalha no cais, carrega, descarrega navio. Anda tudo depressa que nem rato de bordo, com os sacos nas costas. Se um não anda depressa, o branco manda o chicote que é mesmo uma beleza. Os outros ouviam mudos. Um negro tremia de raiva. [...]

Guma se despediu dele com saudade. Ficara dentro dele a história do negro Bagé. É assim aos poucos que o milagre de D. Dulce vai se realizando. ${ }^{14}$

Mas o "discurso exemplar” de Chico Tristeza só vai ter alguma implicação social perto do desenlace do romance quando, no auge da crise econômica do cais, eclode a

14 Ibid., p.168-169 
greve dos estivadores. É um breve momento de síntese e articulação entre as consciências conformadas dos letrados (Doutor Rodrigo, D. Dulce) e as consciências inconformadas porém desmobilizadas do povo marítimo (Guma e os canoeiros).

[...] Mas foi quando rebentou a greve dos estivadores. Os mestres de saveiro e grande parte dos canoeiros fizeram causa comum com os homens da estiva. Os estivadores venceram, as tabelas para transporte em saveiro e canoa também aumentaram. Mas houve perseguições e um estivador de nome Armando teve de fugir e foi no saveiro de Guma, que saía naquela noite já levando carga pela nova tabela. E na noite estrelada o estivador lhe contou muita coisa. Para Guma não era de noite, era a madrugada que surgia.

Dr. Rodrigo prestou grande assistência aos estivadores. Depois de tudo acabado fez um poema, em que terminava dizendo que o milagre que D. Dulce tanto esperava tinha começado a se realizar. ${ }^{15}$

O desenlace da questão social se dá muito rápido do ponto de vista do enredo: a crise comercial, a greve e sua resolução, uma possível formação da consciência política em Guma. Em algumas linhas a pressão econômica cede, o cais retoma a prosperidade sem maior alarde para, esse sim, o grand finale romântico que é a morte trágica de Guma e a ascensão espiritual de Lívia. Em suma, o subtexto sobre o potencial revolucionário do reduto popular paira nos discursos de alguns indivíduos e do narrador, ora sincretizado a uma mitificação cristã, ora anedótico, e tendendo sempre a ceder espaço ao drama amoroso, sem dar sinais efetivos de assimilação pela psicologia das personagens. Assim, a questão social de Mar morto fica sendo um dado acessório acentuando o colorido dramático da vida marítima, e não um elemento estruturante da narrativa.

Barravento, tendo herdado da literatura regionalista a confluência entre a ficção e o documentalismo social, agencia os mecanismos formais em torno do eixo político com ênfases muito distintas das de Mar morto. Conforme vimos, a matriz narrativa é similar: o drama praieiro, os amores marítimos, o trabalho com meios de produção primários e as mazelas sociais, os costumes e a fé candomblezeira das populações negras do litoral da Bahia. O rol dos tipos sociais se restringe, entretanto, na medida em que a 
ação se desloca para a província, sem a mesma variedade de funções e ofícios do cais urbano.

Tendo em vista a própria definição de Glauber do estilo literário regionalista que citamos acima, a matriz comum se evidencia também na incorporação de convenções poéticas ao projetar a relação entre o homem e a terra local (ou o mar) criando momentos alegóricos como no quadro a seguir:

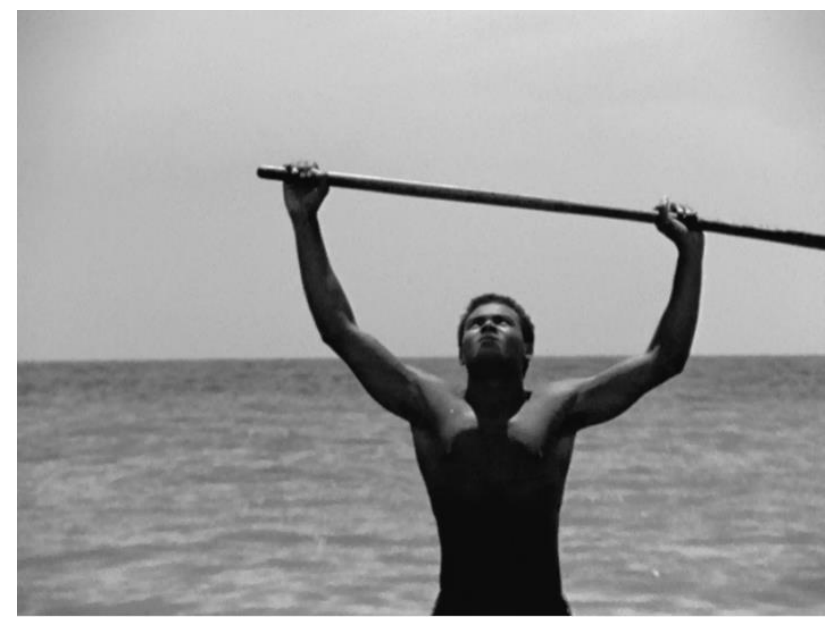

João Luiz Vieira em um testemunho oral chama a atenção para a carga simbólica deste quadro. ${ }^{16}$ Nele, Aruan, voltando triunfante da noite passada no mar, ergue o remo para o céu e contempla o infinito. $\mathrm{O}$ enquadramento suspende e dignifica seu corpo em perfeito equilíbrio com o meio marinho. $\mathrm{O}$ jovem se transforma em uma alegoria épica do homem do mar que se aparenta ao saveirista amadiano na sua consciência íntima do espaço físico que é ao mesmo tempo cósmico.

Apesar desses momentos poéticos, há em Barravento uma tentativa de criar instâncias de distanciamento do objeto ficcional, evitando uma adesão completa à idealização do drama praieiro. Teoricamente, isso permitiria desmistificar o exotismo da narrativa literária e criar uma tensão crítica que dá ênfase à questão social. Mas de que forma esse mecanismo poderia se apresentar?

Ambas as obras, romance e filme, se iniciam com um tipo de "discurso prévio de intenções" que preconfiguram um tipo de narrador e sua relação com a matéria ficcional. No caso de Mar morto, esse narrador anuncia:

16 VIEIRA, João Luiz. in depoimento no DVD 2 de Barravento. Direção: Glauber Rocha. Bahia: Iglu Filmes, 1961. 2 DVD (80 min.) 
Agora eu quero contar as histórias da beira do cais da Bahia. Os velhos marinheiros que remendam velas, os mestres de saveiros, os pretos tatuados, os malandros, sabem essas histórias e essas canções. Eu as ouvi nas noites de lua no cais do mercado, nas feiras, nos pequenos portos do Recôncavo, junto aos enormes navios suecos nas pontes de Ilhéus. O povo de Iemanjá tem muito que contar.

Vinde ouvir essas histórias e essas canções. Vinde ouvir a história de Guma e de Lívia, que é a história da vida e do amor no mar. E se ela não vos parecer bela a culpa não é dos homens rudes que a narram. É que a ouvistes da boca de um homem da terra, e dificilmente um homem da terra entende o coração dos marinheiros. Mesmo quando esse homem ama essas histórias e essas canções e vai às festas de D. Janaína, mesmo assim ele não conhece todos os segredos do mar. Pois o mar é mistério que nem os velhos marinheiros entendem. ${ }^{17}$

A primeira pessoa do discurso se apresenta como um porta-voz do mundo fabular cultivado pelos tipos sociais do cais. Ele é um concatenador de mitos coletados no contato íntimo com os indivíduos desse extrato social. Assim, o narrador-colecionador de histórias de Mar morto é ele-mesmo uma instância ficcional que participa da vida do cais: coloca-se como perplexo ante o mistério que envolve o cotidiano e o culto marítimos, sem dispor dos mesmos recursos de fabulação que possuem os "homens rudes". Seu ponto de vista requer um alto grau de idealização do que está para retratar, o que se reflete no tom confessional de envolvimento patético (de pathos) e estético.

O texto faz um uso reiterado dos termos "canção", "coração", e dos dêiticos "Eu" e "agora" que aproximam o discurso do registro lírico. Ao mesmo tempo, o narrador procura marcar uma distância que não é crítica nem emotiva, mas "de essência", ao se colocar como um "homem da terra". E o discurso se fecha entre o convite e a mistificação absoluta do ambiente local: o mar é um enigma intransponível até para os que lhe são íntimos. O que há para compartilhar nessa fabulação é o mistério cósmico e o espanto diante de suas forças transcendentes que jogam com os destinos dos homens locais. De modo que Mar morto já se inicia com um forte comprometimento entre o ato de narrar e o objeto da narração.

$17 \quad$ AMADO, op.cit., p.2. 
Observemos, em contraste, o avant-propos de Barravento:

No Litoral da Bahia vivem os negros puxadores de xaréu, cujos antepassados vieram escravos da África. Permanecem até hoje os cultos aos deuses africanos e todo esse povo é dominado por um misticismo trágico e fatalista. Aceitam a miséria, o analfabetismo e a exploração com a passividade característica daqueles que esperam o reino divino. "Iemanjá" é a rainha das águas, a "velha mãe de Irecê", senhora do mar que ama, guarda e castiga os pescadores. "Barravento" é o momento de violência, quando as coisas da terra e do mar se transformam, quando no amor, na vida e no meio social ocorrem súbitas mudanças. Todos os personagens apresentados nesse filme não tem relação com pessoas vivas ou mortas e isso será apenas mera coincidência. Os fatos contudo existem. Barravento foi realizado numa aldeia de pescadores da praia de Buraquinho, alguns quilômetros depois de Itapoan, Bahia. Os produtores agradecem à prefeitura municipal de Salvador, ao governo da Bahia, aos proprietários de Buraquinho e a todos aqueles que tornaram possíveis as filmagens, principalmente aos pescadores, a quem este filme é dedicado.

As primeiras frases deste letreiro conjuram um jogo prismático entre invenção e realidade. Apresenta-se a paisagem física onde será encenada uma narrativa ficcional ao mesmo tempo em que se situa a realidade histórica de uma forma de trabalho e de uma comunidade que existe de fato, cujos ancestrais eram africanos escravizados. As personagens são fictícias, mas os fatos existem - isto é, por um lado, explicita-se o artifício da ficção (produtores, não atores, locação, prefeitura de Salvador) e por outro uma verdade social e natural, quase um recorte antropológico. A praia de Buraquinho passa a ser o palco onde se expõem ideias acerca da miséria, do analfabetismo e da exploração reais, desde agora habitado por personagens inventados.

A "instância de enunciação" do letreiro de abertura do filme procura se colocar a uma distância não encantatória da realidade retratada. Do ponto de vista da convenção escrita, um exemplo disso são as aspas em "Iemanjá" e "velha mãe de Irecê”, que marcam uma desapropriação do vocabulário litúrgico dos pescadores, sugerindo um esforço de não-imersão, de não-compactuação. Assim, Barravento anuncia, ao menos na intenção, um distanciamento crítico a que Mar morto renuncia de partida. 
O estudo analítico de Ismail Xavier, "Barravento: alienação versus identidade"18 é revelador dos limites desse distanciamento crítico enunciado pelo letreiro do filme. Nele o estudioso demonstra como a estrutura e a forma fílmica, em momentos decisivos do enredo, acabam reafirmando o viés interpretativo místico que o autor pretendia combater. Deixaremos o estudo mais detido dessas ambivalências, contudo, para o segundo capítulo.

Se pensarmos, entretanto, menos na intenção discursiva que as obras anunciam e mais nas relações intradiegéticas, encontraremos um novo contraponto estrutural na forma como os enredos configuram a questão social. No filme, ele será encampado não por personagens letradas de classe média como Dona Dulce e Doutor Rodrigo, que não pertencem a esse enredo afastado do centro urbano, mas, sobretudo, por um indivíduo marginal e ambíguo, o malandro Firmino.

Sem a longevidade nem a resignação da velha professora como horizonte possível, a presença de Firmino é curta, definitiva e convulsionária. O malandro materializa no enredo de Barravento a ação e o discurso do "mártir popular". Conforme vimos, essa tipificação em Mar morto atravessa a narrativa dentro de uma espécie de parênteses que é o registro anedótico. Os rebeldes e insubordinados do povo, no romance, são figuras míticas evocadas em histórias, lembranças que inspiram os canoeiros, mas que não se presentificam nas relações do enredo. O capoeirista Besouro, Lucas da Feira e Virgulino são referidos como estrelas, emanações cósmicas. Firmino, por sua vez, encarna o espírito revolucionário do herói capoeirista e dos insubordinados mas o traz para a economia do enredo como um dado estruturante. Sem a ação de Firmino, a história não caminha.

Mas há uma disjunção fundamental entre o "mártir-Firmino" e os mártires míticos de Mar morto no tocante ao nível de respeitabilidade junto às suas respectivas comunidades. O caráter do malandro glauberiano e o seu discurso corrosivo passam ao largo de qualquer efeito carismático ou inspirador, incompatível com sua experiência violenta e marginalizada da cidade. Ao agir sob a chave do "custe o que custar", em detrimento da moralidade ou de um código de honra comunitário, ele não inspira nem a confiança nem a simpatia dos seus conterrâneos. A marginalidade urbana de Firmino o assemelha muito mais a uma personagem secundária de Mar morto: Rodolfo, o irmão de Lívia. São os arquetípicos malandros do cais, da linhagem dos Zé Pilintras empunhadores

18 XAVIER, Ismail. Sertão mar: Glauber Rocha e a estética da fome. São Paulo: Duas Cidades; Editora 34, 2019, p.25-59. 
de navalhas: ambos, sofrendo a pressão da exclusão social aliada à necessidade de sobrevivência, resvalam na ilegalidade e disseminam contra seus conterrâneos a violência que também lhes é impingida pelas forças de repressão.

Rodolfo, como Firmino, é um baderneiro, um atiçador que canaliza tensões pela via da violência. Por exemplo, à sua primeira aparição transforma uma rixa "de honra" entre colegas em uma briga de sangue com sua navalha. Ele "não prestava mesmo", diz o próprio narrador, ${ }^{19}$ concordando com Guma que "[...] não disse nada. Ele amava a lei do cais e ela não permitia que se puxasse uma navalha, a não ser quando o adversário era maior em número. Quem não cumpria a lei do cais não valia nada para ele." ${ }^{20} \mathrm{O}$ desrespeito aos códigos compõe um modo de ação desconcertante que orienta os malandros em todas as esferas: tanto no âmbito da lei oficial, gerando problemas com a polícia, quando da lei tradicional que define o código de honra na comunidade.

Os dois malandros são naturalmente inconformados e desajustados. O desajuste se traduz no despertencimento a esferas sociais de qualquer ordem, o que faz de Rodolfo e Firmino indivíduos em constante movimento, excluídos e malquistos tanto em suas próprias comunidades quanto na cidade alta:

Já Rodolfo não parecia um homem dali. Seu pai chegara um dia, abrira uma venda, que faliu. Apesar disso, não saiu do cais, arranjou uma portinhola no mercado, vendia na feira de Água dos Meninos. Rodolfo nasceu, era um branco bonito, cabelo bem liso, que ele trazia tratado a brilhantina. Quando cresceu, deixou o leme do saveiro que o pai lhe arranjara, desertou das águas e vivia aparecendo e desaparecendo. Por vezes chegava com muito dinheiro, pagava cachaça para todos, fazia freguês no "Farol das Estrelas". Outras vezes aparecia quebrado a pedir dez tostões emprestados, a beber à custa dos outros. No cais olhavam para ele com certo receio e diziam que não era "boa bisca". ${ }^{21}$

O “não parecer” de Rodolfo é ambíguo no excerto acima porque envolve uma mistura entre características inerentes ao indivíduo e o capital simbólico-estético que ele agregou a si. Sua ancestralidade não é do cais, é filho ilegítimo de uma pequena burguesia

\footnotetext{
$19 \quad$ AMADO, op.cit, p.38.

20 Ibid., p.38.

$21 \quad$ Ibid, p.39.
} 
comerciante falida, o que repercute em suas características físicas, pois é branco em uma comunidade majoritariamente negra.

$\mathrm{O}$ personagem acentua deliberadamente seu despertencimento racial ao passar brilhantina nos cabelos lisos, e recusa o símbolo do destino econômico local ao abandonar o saveiro. Há em Rodolfo uma pulsão de distanciamento estético e econômico com relação ao estrato social que o cerca, e ele procura se construir salientando distinções inerentes (ser branco) e adquirindo outras (não ser canoeiro), oscilando entre "não parecer" e "não querer parecer", mas sempre em oposição ao seu entorno.

A equação se complica um pouco mais em Firmino, porque ele é um filho legítimo de gente praieira que foi renegado tanto pelo próprio pai quanto por sua comunidade. Há um ressentimento por trás do "não querer parecer" que explica a sua recusa sistemática ao sistema de valores ao qual pertenceria organicamente. Isso explica em parte uma série de ambivalências entre suas motivações e sua ação: ele conhece a prática ritualística do santo, e se serve dela contra o sistema sagrado. É um capoeirista habilidoso, boêmio, se vangloria de sua habilidade em burlar a lei e dos modos de homem urbano, mas vem fugido da polícia buscar esconderijo em Itapuã. Em suma, Firmino percorre uma zona fronteiriça onde os limites apreensíveis entre um sistema de valores urbano secularizado e a ordem cósmico-mítica se confundem. Daí que, para tornar Aruan um homem secularizado à sua semelhança, precisa profaná-lo, extraindo-o do sistema sagrado.

De todo modo, a dialética entre o "não parecer" e "não querer parecer" produz tanto em Firmino quanto em Rodolfo um inconformismo, em relação a si mesmos e a realidade em torno, que se transforma em movimento: ambas as personagens vivem da mudança como um princípio organizador da vida. Eles são irrequietos em um mundo de formas estanques: representações sociais, econômicas, religiosas e dinâmicas de exploração e poder. Mas a ambiguidade do caráter desses malandros também se alimenta da crise de solidão que os assola quando se combinam a radicalidade das convicções e uma forma de vida "independente" dos sistemas, a uma autoconsciência da marginalidade. $\mathrm{O}$ sofrimento aparece como uma contraface vulnerável em meio à vida improvisada, pela constante ameaça do confrontamento com a polícia e a prisão. Em Mar morto, Rodolfo confessa: 
Lívia: Até quando tu quer levar essa vida sem jeito, Rodolfo? Tu podia parar, arranjar qualquer coisa direita pra fazer... Essa vida não serve, você vai acabar mal, os outros vão sentir...

Rodolfo: Ninguém sente por mim, Lívia. Sou um traste ruim, ninguém gosta de mim. ${ }^{22}$

\section{E em Barravento:}

Firmino: Ainda bem que você gosta de mim, se as coisas fossem diferentes eu até que me arrumava.

Cota: Ainda não fez porque não quer. A renda não dá?

Firmino: A renda mal serve pra ter uns panos decentes em cima do corpo. Estou sem oportunidade, como diz um amigo. A ficha na polícia anda muito descarregada, e agora inventaram até uma palavra nova: "elemento subversivo".

Cota: [...] Por que você não endireita o caminho, e vem viver como os outros?

Firmino: Eu pescador? Isso aqui é vida de índio. [...] Meu sofrimento ninguém vê, sou diplomado em matéria de sofrer...

Apesar da complexidade intrínseca ao malandro, na medida em que o drama amoroso do romance vai ganhando preponderância, o malandro Rodolfo, embora cada vez mais presente, vai perdendo seu caráter indócil e provocador para orbitar em torno de Lívia e Guma. Sua malandragem passa a estar a serviço de acentuar, pelo contraste, a retidão moral do casal, de modo a compor um colorido acessório da tipologia dos caracteres do cais, o que parece ser uma tendência de Mar morto. Há um malandro, assim como há um mestre saveirista, assim como há prostitutas etc. Esses caracteres secundários enriquecem a paisagem humana da fábula mas não constroem o sentido da narrativa com profundidade psicológica ou tensão crítica. Parece ser sistemático que as personagens de Mar morto percam consistência quando a trama amorosa vem para o primeiro plano: isso acontece com o velho Francisco, Rosa Palmeirão, Rufino, Rodolfo e assim por diante.

A síntese radical de Barravento consiste, do ponto de vista do enredo, em inverter as ênfases de Mar morto. O drama praieiro vai para o segundo plano, o malandro 
vem para o centro acentuando o seu discurso em torno da questão social, e ganha uma camada a mais de urgência, com uma pulsão revolucionária. Mas é importante ter em vista que nem sempre foi assim. O filme como o conhecemos é fruto de uma operação deliberada de Glauber Rocha a partir da reformulação de um roteiro original, muito menos vibrante. Em que medida o afastamento da matriz amadiana se constrói como uma perspectiva crítica é o que analisaremos logo adiante.

\subsubsection{Dados do processo Barravento}

Como se sabe, a concepção do primeiro longa-metragem de Glauber Rocha é em si mesma uma história de reviravoltas. $\mathrm{O}$ argumento inicial era de Luiz Paulino dos Santos, diretor do documentário Um dia na rampa (1960) que, segundo consta, ${ }^{23}$ estava imbuído de um sentido mais contemplativo e valorizante quanto ao candomblé. Humberto Pereira da Silva nos informa de que Barravento tratava, a princípio, do romance de uma menina branca moradora de um vilarejo de pescadores que se apaixona por um jovem negro da cidade. Ela deixa o vilarejo para acompanhá-lo, mas acaba sendo abandonada e se torna prostituta. Por fim, a jovem retorna à sua terra natal e se reconecta com suas origens.

O jogo erótico entre identidades raciais distintas, a aproximação da narrativa do baixo centro urbano com seus tipos marginais, a preponderância do drama romântico tendo como pano de fundo o universo cósmico-trágico dos Orixás, no pouco que se sabe desse primeiro roteiro, ecoam fortemente a "cor local" do universo ficcional de Jorge Amado. Não é senão o próprio Glauber Rocha, então produtor do filme, quem declara à imprensa soteropolitana em 1959:

Praia de Itapoã, festa de Yemanjá, som de atabaque, morena sensual, fortes e corajosos pescadores emoldurados por mar e coqueiral estarão reunidos em Barravento, primeiro filme baiano que fixará nas telas as belezas de nossa terra [...].

23 SILVA, Humberto Pereira da. Glauber Rocha: Cinema, Estética e Revolução. São Paulo: Paco Editorial, 2016, p.30. 
- Barravento é uma produção que poderia ser classificada como uma promoção de turismo na Bahia, através de filme. ${ }^{24}$

A fala de Glauber explicita a representação de tipos sociais dentro de uma conjuntura ornamental. O olhar externo é demarcado pela erotização da paisagem humana: corpos fortes, míticos, enquadrados pela natureza exótica, as belezas da terra um paisagismo sensual que se oferece sem tensão ao espectador. Há uma tonalidade de convite nesse enunciado que faz pensar no narrador amadiano que nos chama a ouvir histórias do mar.

Essa primeira versão não chega a ser realizada porque incidentes e desentendimentos na produção levam Luiz Paulino a abandonar o projeto. Glauber Rocha compra o argumento e o reescreve junto a José Telles Magalhães. Não obstante, algo se transforma radicalmente na perspectiva do novo diretor quando, ao se instalar no sítio de filmagem, descobre a miséria da população praieira de Itapoã. Glauber passa a assumir um ponto de vista crítico com relação à religião, e autocrítico quanto ao exotismo, o que o leva a reescrever o roteiro:

Chegando em Buraquinho, as coisas mudaram para mim. Descobri uma realidade até então desconhecida e fui obrigado a deixar de lado o roteiro que havia feito. Passei a ver o filme de outra maneira, tanto do ponto de vista temático como formal. $\mathrm{O}$ exotismo da cultura negra, tão cantado pelos artistas de origem baiana, não passa de uma romântica e alienada posição diante de um grave problema de subdesenvolvimento, físico e mental. Os negros permanecem escravizados de todas as formas. Talvez a pior delas seja a religião, a crença nos deuses africanos, a eterna submissão à miséria, como se aquele destino de fome e analfabetismo fosse determinado por Iemanjá ou Xangô. Fatalismo absoluto. $^{25}$

De maneira que há três etapas na elaboração do filme: o argumento de Luiz Paulino dos Santos, jamais publicado; o roteiro de Glauber e José Telles baseado neste

24 ROCHA, Glauber. in Jornal da Bahia, Salvador (BA). 10 março 1959.

25 ROCHA, Glauber. in JUNIOR, Walter Lima. Correio da Manhã, Rio de Janeiro (RJ), 17 abril 1962. 
argumento e, enfim, um roteiro de maior tensão crítica, refeito no calor de novas ideias. $\mathrm{O}$ aspecto físico dos roteiros, que se encontram conservados na Cinemateca Brasileira, é um indício do estilhaçamento da forma original no processo criativo de reformulação. $\mathrm{O}$ primeiro, uma brochura em bom estado de conservação, cuidadosamente datilografada e com raras interferências a mão, o segundo, uma brochura com folhas datilografadas bastante desgastadas, inúmeros rabiscos a mão, trechos recortados e colados, desenhos, numerosas rasuras de fala e acréscimos a lápis ou à caneta, além de alguns fragmentos avulsos.

Nesse percurso de modificações e radicalização, Glauber também vai se afastando conscientemente do aspecto contemplativo-romântico da matriz regionalista praieira. $\mathrm{O}$ abandono da linha narrativa linear encontra seu correspondente formal na ruptura da sintaxe fílmica, articulando um enredo mais fragmentário e dialético a uma montagem irregular, melhor afinada com o discurso crítico. Os vestígios textuais desse processo podem ser evidenciados pelo cotejo entre as duas versões do roteiro.

A título de exemplo, observemos o que seria o prólogo original de Barravento, transcrito abaixo a partir da brochura original.

Prólogo

\section{SEQUÊNCIA 1-exterior-dia-mar}

\begin{tabular}{|l|l|l|}
\hline $1-$ & $\begin{array}{l}\text { P.S. Pan ceu limpo } \\
\text { Grande extensão de céu.As nuvens } \\
\text { vão correndo,fecham escuras e pe- } \\
\text { sadas }\end{array}$ & Surge e cresce barulho de mar \\
\hline $2-$ & $\begin{array}{l}\text { Pan. 2 do mar calmo para } \\
\text { Superfície do mar encapelado. }\end{array}$ & Idem,crescendo \\
\hline $3-$ & $\begin{array}{l}\text { Folhas de cequeiro agitam res- } \\
\text { ende (?) }\end{array}$ & Son do mar e vento \\
\hline $4-$ & $\begin{array}{l}\text { Camisa do pescador agita sob o vento } \\
\text { [rasgado manchado] um “carneirinho" sê- } \\
\text { xxxxxxxxxxxxxx água. }\end{array}$ & Son de àgua,vento.... \\
\hline $5-$ & $\begin{array}{l}\text { [rasgado manchado]. A mão sobre o olho vel- } \\
\text { xxxxxxxxxxxx ma. Movimento }\end{array}$ & Idem, crescendo \\
\hline $6-$ & [rasgado manchado]cobre o sol totalmente & Idem.... \\
\hline $7-$ &
\end{tabular}




\begin{tabular}{|c|c|c|}
\hline 8- & 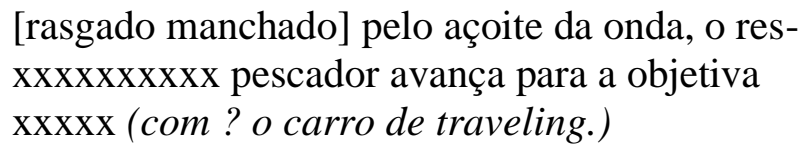 & Idem.... \\
\hline $9-^{8-}$ & $\begin{array}{l}\text { O pescador foge de costas, levado pela } \\
\text { onda.Equilibra-se por cima da jangada } \\
\text { (com o carro de traveling.) }\end{array}$ & Idem.... \\
\hline $10-^{9-}$ & $\begin{array}{l}\text { Mar fechado.Jangada perdida no meio } \\
\text { como minusculo ponto.Tempo fechado,v } \\
\text { violento..... }\end{array}$ & Idem.... \\
\hline $111^{10-}$ & $\begin{array}{l}\text { Um jorro d'água lava o rosto do pes- } \\
\text { cador }\end{array}$ & Idem.... \\
\hline $11-$ & Onda alta para a objetiva & Idem.... \\
\hline 13- & A onda (?) & \\
\hline
\end{tabular}

p. 2

\begin{tabular}{|c|c|c|}
\hline $13-$ & $\begin{array}{l}\text { As copas do coqueiro quebrando com } \\
\text { o vento frente a objetiva }\end{array}$ & Idem.... \\
\hline $14-$ & A onda quebra envolvendo tudo & Idem.... \\
\hline $15-$ & O rosto do pescador passa rápido & Idem.... \\
\hline $16-$ & $\begin{array}{l}\text { A frente da jangada desce afundando } \\
\text { no meio da onda }\end{array}$ & Idem.... \\
\hline $17-$ & $\begin{array}{l}\text { As mãos do pescador se agarram de- } \\
\text { sesperadamente no banco (ou mastro) } \\
\text { da jangada }\end{array}$ & Idem.... \\
\hline $18-$ & $\begin{array}{l}\text { O rosto do pescador estampa o pavor } \\
\text { e o medo da morte }\end{array}$ & $\begin{array}{l}\text { Vento e mar furioso cres- } \\
\text { cendo....... }\end{array}$ \\
\hline $19-$ & $\begin{array}{l}\text { Outra onda violenta avança e envol- } \\
\text { ve a jangada e homem, escurecendo o } \\
\text { quadro com grande violência }\end{array}$ & $\begin{array}{l}\text { Com grande fúria estouram } \\
\text { ruídos do mar e do vento, ruí- } \\
\text { dos de trovoada crescendo, } \\
\text { dando a impressão de que o } \\
\text { mundo se acaba }\end{array}$ \\
\hline $20-$ & $\begin{array}{l}\text { Sobre o negro passa, surgindo em gran- } \\
\text { des letreiros brancos } \\
\text { "BARRAVENTO" }\end{array}$ & $\begin{array}{l}\text { Idem......ATABAQUES EM / } \\
\text { Idem..... CLIMAX } \\
\text { Idem..... }\end{array}$ \\
\hline
\end{tabular}




\begin{tabular}{|l|l|l|}
\hline & \multicolumn{1}{|c|}{- a fúria de Yemanjá- } & Som absoluto e ensurdecedor \\
\hline $21-$ & $\begin{array}{l}\text { A jangada,boia,sozinha,mastro quebrado no } \\
\text { meio do mar }\end{array}$ & $\begin{array}{l}\text { Cânticos de ritual fúnebre } \\
\text { dos candomblés... }\end{array}$ \\
\hline $23-$ & $\begin{array}{l}\text { Cam. corre do mar para a praia } \\
\text { acompanhando onda que quebra e rola } \\
\text { na areia branca }\end{array}$ & $\begin{array}{l}\text { Duas marcas de passo.Cam.levanta } \\
\text { seguindo as marcas encontradas e em- } \\
\text { quadra uma velhinha de pretoque anda } \\
\text { pela praia rumo ao infinitoCam.deixa } \\
\text { a mulher e corre pelo coqueiral }\end{array}$ \\
\hline
\end{tabular}

p.3

\begin{tabular}{|l|l|l|}
\hline $24-$ & $\begin{array}{l}\text { Filhas de santo caminham na direção } \\
\text { do barracão em frente.Todas as FS } \\
\text { entram no barracão,desaparecendo todas } \\
\text { no escuro da porta.Negro. }\end{array}$ & Idem..... \\
\hline $25-$ & $\begin{array}{l}\text { Sobre o negro surge o letreiro } \\
\text { uma produção REX SCHINDLER E IGLÚ } \\
\text { FILMES } \\
\text { elenco.................................................. } \\
\text { técnica................................................. até o } \\
\text { fim. }\end{array}$ & Idem.... \\
\hline
\end{tabular}

Ao invés de um letreiro explicativo, há uma cena marítima, o que significa de partida uma aposta no trabalho poético da imagem em detrimento do elemento discursivo. Nela vê-se um homem desconhecido navegando em alto-mar com sua jangada. A natureza subitamente se transforma com o princípio de uma tempestade, os coqueiros, o céu, o vento e as ondas vão se agitando, o pescador se vê em apuros. A câmera se aproxima e distancia para testemunhar ora a inquietação crescente do homem, que logo se transfigura em terror, e uma luta desesperada contra a borrasca, ora a pequeneza de sua jangada na imensidão do mar enervado. Uma onda engole sua modesta embarcação. A cena escurece acompanhada pelo estardalhaço dos sons da tempestade. No fundo negro, lê-se: Barravento - a fúria de Yemanjá. 
Após o estouro, constata-se a vitória implacável da natureza. A carcaça da embarcação estilhaçada boia sem seu condutor. Ao fundo, ouvem-se os cânticos do axexé, o rito fúnebre do candomblé, o que dá uma conotação mística à morte do pescador. A câmera, como se fosse levada pelas ondas, chega na areia onde encontra uma velhinha de preto "que anda pela praia rumo ao infinito". Vê-se o coqueiral e, por fim, as filhas de santo entrando no barracão. De novo, a cena escurece para a entrada do letreiro técnico, após o quê o drama se desenrola.

Observemos como o prólogo original de Barravento se constituía de uma montagem épico-alegórica da relação do homem praieiro com o espaço natural. Por um lado, anunciava a dimensão trágica do embate do pescador com o mar e a preponderância da natureza sobre a minimidade do homem. Por outro, a rotina de reverência e a ancestralidade representada pelas figuras da velhinha caminhando no infinito da praia e das filhas de santo no barracão.

Não existe uma presença corporificada do sagrado, senão na menção a Iemanjá do subtítulo, mas a interação da imagem com a banda sonora anima os elementos da natureza, tornando-os uma força viva conspirando contra o homem. A câmera permanece aliada à natureza inclusive no seu retorno para a praia, como um despojo da maré. Ela desliza do mar para as pegadas na areia, das pegadas para a velhinha, da velhinha para o coqueiral, do coqueiral para as filhas de santo - a sintaxe da cena vai reiterando a comunhão entre as figuras do sagrado e a paisagem, criando uma circularidade que o batuque hipnótico do axexé consolida.

Há dois momentos complementares de escurecimento de cena que sugerem a imersão da câmera, e portanto do olhar, no microcosmo local: primeiramente, a câmera é engolida pelo mar tempestuoso junto ao pescador, quando surge o título do filme, depois entra na penumbra do barracão, quando aparece o letreiro técnico. Cria-se um paralelismo entre os dois espaços: a passividade diante da realidade física da natureza no auge de sua força destrutiva e, em seguida, a busca ativa por conciliação espiritual no espaço litúrgico. O primeiro Barravento anuncia, por essas relações, um perfeito acordo da representação fílmica e das escolhas formais com o sistema de valores local, baseado na ideia de um destino determinado pela divindade, cuja vontade se manifesta na natureza.

Mais uma vez, poderíamos associar o espaço simbólico criado pela tríade homem-natureza-sagrado com Mar morto. O romance se abre igualmente com uma tempestade. Desde o título a relação entre a vida material e o universo espiritual se explicita: "Iemanjá, dona dos mares e dos saveiros", isto é, a presença subentendida da 
deusa comanda tanto a natureza quanto o destino dos indivíduos que dela sobrevivem. Assim como no filme, a tempestade do romance é, paradoxalmente, o momento de efetivação da morte como cumprimento da vida do pescador e de devoção máxima da comunidade local. No começo do capítulo, o batuque dos candomblés se interrompe, a luz do cais se apaga, os festejos silenciam para deixar passar o temporal. O temor resignado dos pescadores paira no cais mas também o som do sexo entre Maria Clara e o Mestre Manuel, que se confunde com os ruídos da borrasca.

Barravento, e agora pensamos no filme tal qual foi realizado, embora tenha suprimido o prólogo grandiloquente em favor do letreiro antiimersivo, ainda preserva algumas relações simbólicas entre a corporeidade humana e a natureza, tais como a analogia amadiana entre a eclosão da tempestade e a consumação do ato sexual. A análise de Ismail Xavier da sequência que sucede à dessacralização de Aruan explicita como, através de um jogo de câmera, o gozo viril do jovem se projeta na natureza com a explosão do barravento. ${ }^{26}$ A tempestade representa, assim, em ambos, pela via do temor e da morte, o clímax da comunhão entre o pescador e sua fé trágica, e pela via do sexo, a realização máxima da potência de vida carnal. O romance faz uma síntese dessa dupla pulsão de morte e vida ao reiterar o aspecto incestuoso do amor de Iemanjá, mãe e amante dos pescadores, que consuma seu desejo erótico pelo afogamento de seus protegidos.

Os vestígios de tais relações simbólicas, na versão final do filme, entram em disputa com a urgência do sentido crítico e materialista que a reformulação do enredo acarretou. Daí a ambivalência também apontada por Ismail Xavier, entre os dois caminhos interpretativos do filme: o materialista e o espiritual, sem a prevalência de nenhum deles.

\subsection{2. África-Brasil}

Em última instância, a disjunção ideológica entre Glauber Rocha e o imaginário romântico do regionalismo praieiro de Jorge Amado se dá por uma problemática da representação. No ensaio sobre Lins do Rego, do qual citamos um excerto mais acima, Glauber detecta o interesse interpretativo da relação entre "a terra e o homem" como o nó central do romance regionalista. Ao colocar em discussão as relações de exploração econômica que permeiam esse binômio fundamental, da terra e do homem, como um dado

$26 \quad$ XAVIER. op. cit. p.41-52. 
estruturante do enredo, o cineasta propõe uma perspectiva menos condescendente e comprometida com os valores do indivíduo local. Sem abandonar de todo o aspecto fabular, as personagens centrais de Barravento são tratadas ao mesmo tempo como vítimas de uma mazela social e parte da causa, na medida em que estão colocadas em xeque as tensões dos indivíduos com a realidade social e histórica (a exploração do trabalho), mas também com sua própria representação do mundo (a religiosidade e o fatalismo).

Em correspondência enviada a Paulo Emílio Sales Gomes em novembro de 1960, portanto durante as filmagens de Barravento, Glauber registra seu afastamento da "maneira de Jorge Amado":

Esses candomblés, embora possuam valor cultural inestimável, adormecem uma raça de fantásticas possibilidades. Uma raça que, segundo vejo, eu que convivo com maioria de negros, poderá se emancipar de vez no Brasil paralelamente à grande independência africana. Vivemos aqui com a Nigéria na ponta do nariz e são os próprios nigerianos visitantes que deploram o fetichismo pernicioso. Barravento é um filme contra os candomblés, contra os mitos tradicionais, contra o homem que procura na religião o apoio e a esperança.

O negro é fantástico no seu ritmo de andar, de falar e amar. Mas é detestável até mesmo essa antropologia de salão que qualifica o negro de excepcional porque é "negro". Aí está o racismo! Os negros de Barravento no roteiro que refiz são homens vítimas da condição de "negro", mas são sobretudo homens; tanto os belos quanto os maus assim o são porque "homens" e não "raça".

O que Camus fez foi uma canalhice e de certa maneira nossa literatura negra é a mais racista de todas as contribuições artísticas nacionais. $\mathrm{O}$ próprio Jorge de Lima. O próprio Jorge Amado. Negro é "como negro", eis a essência deles. ${ }^{27}$

No fundo, parece estar em jogo a representação do homem negro na cultura brasileira. A essa época, Glauber rejeita o academicismo antropológico ou a busca pela

27 ROCHA, Cartas ao mundo (org. Ivana Bentes). São Paulo: Companhia das Letras, 1997, p.126. 
representação documental dos caracteres populares que não estejam a serviço de veicular uma ideia de mudança social. Por conseguinte, o jovem diretor se alinha a uma espécie de "ética brechtiana" 28 do fazer artístico, segundo a qual a adesão e o encantamento com a beleza do fenômeno humano seriam um fator de alienação do artista, um obstáculo para a arte engajada despertar o potencial revolucionário de populações historicamente marginalizadas.

No que diz respeito a Barravento, o recorte é sobre as populações negras do litoral da Bahia, descendentes dos africanos trazidos para o país sob a violência do longo regime escravocrata brasileiro. Ao que parece, no entender de Glauber, essas populações vinham sendo sujeitas a uma representação erotizante e exótica por parte da cultura dita oficial, o que aplacaria certas verdades históricas: a tensão da exclusão social, a exploração econômica e a repressão das classes dominantes. No fundo a intenção crítica de Barravento não se dirige apenas contra a vivência da religião popular, mas contra a forma romântica e decorativa com que a cultura brasileira a representa por um viés antropologizante e paternalista - o que seria, de outra forma, racista. Daí a crítica à tipificação romântica de Jorge Amado.

Ao falar em emancipação da população negra o diretor tem como horizonte dois fatos históricos que não estavam à vista nos anos 1930 de Mar morto: o processo de independência dos países africanos e a Revolução Cubana.

Não foi somente aprender o artesanato (que continuará na montagem) mas compreender melhor a vida frente a uma paisagem humana. Não me interessa o fato regional, mas logo pensei nas lutas da África e da Argélia. Isto para não lembrar Cuba e foi, por uma coincidência inestimável agora descoberta no livro de Sartre, "Furacão sobre Cuba", que encontrei a técnica da revolução igual àquela usada por Fidel Castro para levantar os camponeses contra Batista. Foi assim que, alcançando um sentido social, descobri que a imagem decorativa é o suicídio do homem moderno e foi por isto que me revoltei contra o desespero de

28 Orlando Senna chega a afirmar em artigo após a estreia do filme: "Temos de concordar que Bertolt Brecht, a teoria cinematográfica defendida por Brecht, é o ponto de apoio para o jovem diretor." in Diário da Noite, (BA), 28 maio 1962. 
Fellini diante da evidência Afro-Asio-Americana. Confesso que, a cada dia que marchava para a colônia de pescadores, descobri a política. ${ }^{29}$

Além daquele já mencionado interesse inato pelo fenômeno da cultura brasileira, não seria forçoso dizer que encontramos aí alguma identificação da consciência terceiromundista que agitava a neovanguarda europeia com que Glauber conviveu em seus anos de formação acadêmica. É inegável, nesse sentido, uma confluência entre as ideias sobre a alienação religiosa de Glauber e a teoria crítica de Frantz Fanon sobre o colonialismo, ainda que a essa altura houvesse muito pouca difusão dos escritos do psicanalista martinicano no Brasil. Voltaremos a Fanon nas análises das personagens de Barravento.

Em todo caso, é provavelmente por essa razão que a África aparece como um pano de fundo de Barravento em dois momentos chave, quando a pulsão revolucionária dos discursos de Firmino e Aruan se explicita:
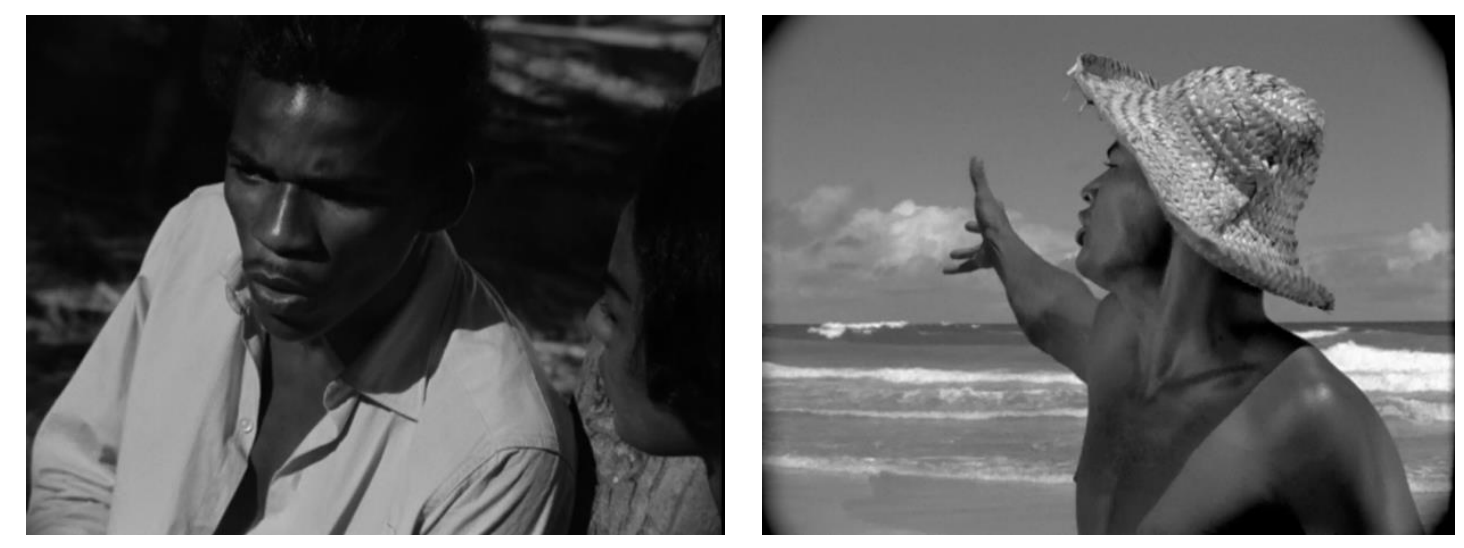

Firmino: Eu, pescador? Isso é vida de índio. Aruan: Nós temos que reagir. Viemos de lá Isso aqui não é África, é Brasil. escravos, mas a escravidão já acabou.

Vimos anteriormente que a menção à África também figura em Mar morto, em um arranjo linguístico muito semelhante. Isto é, a partir da articulação entre dêiticos que alegorizam uma relação geográfica e histórica, logo espacial e temporal, entre a cultura brasileira e sua matriz africana: "lá-África", "aqui-Brasil". No caso do romance, é o navegante Chico Tristeza quem diz: 
- Lá pras bandas da África onde eu tive, meu povo, vida de negro é pior que vida de cachorro. Tive nas terras dos negros que agora são dos Franceses. Ali negro não vale nada, negro é só escravo de branco, apanha de chicote. E ali é terra deles... ${ }^{30}$

O distanciamento histórico entre o romance e o filme revela, em um sentido mais amplo, o tipo de representação da matriz africana que estava em perspectiva nos dois momentos da cultura: nos anos 1930, como uma fonte fabular e um fundo folclórico da identidade nacional, e nos anos 1950-60, como palco de revoluções políticas ligadas a uma consciência do subdesenvolvimento, com a ascensão de novos centros metropolitanos terceiro-mundistas. E essa representação vai se refletir no teor dos registros narrativos quando entra em cena o jogo "África-Brasil".

No caso do enredo de Mar morto, a menção à África é feita dentro do registro anedótico. A fala transcrita acima é proferida por Chico Tristeza no seu retorno ao cais, revestido de uma aura épica por conta da sua experiência do além-mar que causa admiração e respeito de seus conterrâneos ("Ele sabia línguas esquisitas, andara por terras quase tão distantes como as de Aiocá" ${ }^{31}$ ). No reencontro com seus antigos companheiros de trabalho, o marinheiro evoca os paradeiros distantes que visitou e dá notícia dos efeitos nefastos do colonialismo europeu sobre a população negra africana, mas também de um caso de insubordinação, da resistência do foguista Bagé. ${ }^{32}$

O episódio de Chico Tristeza prenuncia o momento de revolta popular efetiva no romance, a greve dos estivadores, conforme mencionamos anteriormente. Enquanto o recém-chegado conta a história na frente do mercado, um homem negro anônimo o acompanha atentamente e reage com entusiasmo. Assim, como um efeito colateral aparentemente inesperado, Chico insufla um tipo de consciência social nos seus conterrâneos: "Guma se despediu dele com saudade. Ficara dentro dele a história do negro

\footnotetext{
$30 \quad$ AMADO, op. cit., p.168.

$31 \quad$ Ibid., p.167.

32 Não é possível afirmar se haveria nesse episódio alguma evocação à Revolta da Chibata, que eclodiu no Brasil em 1910. Como se sabe, esse motim naval envolveu questões raciais remanescentes do regime escravista: os abusos e maus tratos de marinheiros negros perpetrados por oficiais brancos da Marinha, oriundos de elites econômicas. Em todo caso, a semelhança anedótica chama a atenção.
} 
Bagé. É assim aos poucos que o milagre de D. Dulce vai se realizando." 33 O narrador sugere que um espírito de mudança social começa a ser organicamente incutido nas personagens pelo princípio de identificação com as histórias do marinheiro.

Do mesmo modo como o romance evoca os heróis populares (Besouro, Lucas da Feira, Virgulino) na qualidade de emanações cósmicas velando sobre o destino dos homens do cais, a África ocupa um espaço fabular, repositório de histórias inspiradoras e originais. O narrador, por sua vez, cede ao mesmo encantamento das personagens ao aproximar os países longínquos que Chico Tristeza percorreu e a terra mítica de Aiocá, onde Iemanjá se originou.

Já em Barravento, a África é evocada nos discursos de Firmino e Aruan como um passado atávico. O "lá-África" é o resquício de um atraso histórico ligado ao escravismo que precisa ser sobrepujado tanto do ponto de vista social, pela revolta contra a exploração econômica, quanto do ponto de vista cultural, pelo abandono das práticas religiosas alienantes. O malandro Firmino, na busca de afirmação de seu caráter urbano inconformado, associa a África à "vida de índio", à condição de não-civilizado e à estagnação. Já Aruan, ao incitar seus colegas pescadores à resistência, se refere à África no contexto do passado escravista, ao conformismo quanto às velhas estruturas de opressão.

Em suma, um dos gestos fundamentais em Barravento consiste em trazer para um debate cênico elementos fabulares sedimentados pela tradição regionalista, em vista de uma dupla transformação: a quebra da aura museológica da cultura popular e da própria estrutura da obra de arte regionalista como se fizera até então. Esta última não apenas como uma necessidade estetizante de vanguarda. $\mathrm{O}$ horizonte final é o encontro da comunicabilidade que Glauber Rocha tanto admirava na obra de Jorge Amado. Daí a procura por uma fórmula antropofágica, sintetizada bem mais tarde, já no final de sua carreira:

Este filme [A Idade da Terra] é o filme mais moderno e revolucionário dos anos 70 no mundo. É novo em enquadramento, em som, interpretação, montagem - uma novidade Barroca-épica. Quer dizer, o épico de Brecht, no brabo barroco de Jorge. ${ }^{34}$

\footnotetext{
$33 \quad$ AMADO, op. cit, p.169.

34 ROCHA, Revolução do Cinema Novo. São Paulo, Cosac \& Naify, 2004. p.635.
} 
Isto é, a fusão cinematográfica entre a ética brechtiana e a força política do romance de 1930:

Influenciado por Bahia de Todos os Santos e pela descoberta mais aguda do sentido político do cinema e também pela literatura de esquerda que estava lendo no momento, quer dizer, Jorge Amado, Graciliano Ramos, pela Literatura Brasileira de 1930, pela descoberta de Brecht na Escola de Teatro da Bahia através de Martim Gonçalves, e influenciado também pela desmistificação visual que o Trigueirinho tinha feito do barroquismo jesuítico baiano criado pela retórica do Padre Vieira e por todos aqueles escultores portugueses para alienar a mulataria. Em suma, eu via que não tinha folclore, que não tinha nada, quer dizer, era miséria mesmo. E com negros porque os negros pagaram o preço aí, desse processo, que são os escravos lá... que a infra-estrutura dos homens significantes são os pretos porque são eles que... que... são eles que pagaram o preço. Escravidão. ${ }^{35}$

É evidente que não se esgota aí o diálogo entre a primeira obra de Glauber e a matéria regionalista praieira. O interesse pelo modo de vida das populações litorâneas da Bahia e as diferentes manifestações culturais afro-brasileiras encontra reverberações não apenas na literatura, mas em um certo cinema da geração Jorge Amado. Dedicamos o item seguinte à análise das relações entre Barravento e essa matriz fílmica, da qual Alexandre Robatto Filho é um expoente.

\subsection{Uma fonte fílmica: Robatto Filho}

Além da literatura regionalista de Jorge Amado, há uma ampla gama de representações dos elementos da cultura afro-brasileira que contribuiu para uma construção arquetípica da Bahia ao longo da primeira metade do século XX. Conforme enunciamos no item anterior, diversos campos do conhecimento e das artes eruditas

35 ROCHA in depoimento no DVD 2 de Barravento. Direção: Glauber Rocha. Bahia: Iglu Filmes, 1961. 2 DVD (80 min.) 
passam a reconhecer a capoeira, o candomblé e o samba de roda não mais como manifestações folclóricas, mas como domínios complexos da cultura, com um poderoso aparato estético e uma contribuição viva à formação da identidade brasileira. O modo de vida praieiro do litoral baiano, ao congregar muitas dessas manifestações, ganha importantes registros entre os anos 1940-1950.

Um exemplo importante são os ensaios etnofotográficos da pesca de xaréu por Pierre Verger. O fotógrafo francês estava em estreita colaboração com o jornalista Odorico Tavares, responsável pela revista $O$ Cruzeiro. Fruto dessa parceria, é lançada em outubro de 1947 a fotorreportagem “A pesca do Xaréu”, reunida em 1964 no livro Bahia: imagens da terra e do povo.

Em novembro de 1951, é o fotógrafo José Medeiros, junto ao jornalista Arlindo Silva, quem publica também por $O$ Cruzeiro um artigo de grande importância histórica, apesar do título um tanto sensacionalista: “As noivas dos deuses sanguinários”. Gerando repercussão e polêmica, ${ }^{36}$ essa fotorreportagem é o primeiro registro fotográfico de que se tem notícia dos ritos iniciáticos da camarinha, até então guardados em segredo pela liturgia candomblezeira. Interessante notar como, quase dez anos depois, Glauber Rocha será o primeiro diretor a transpor essa imagética para o cinema. Não seria uma casualidade, já que o jovem cineasta baiano certamente teve contato com esse material:

Cearense, superstar nas páginas de $O$ Cruzeiro a melhor revista terceiromundista, nos anos 50, Luiz Carlos Barreto, Luciano Carneiro, José Medeiros eram fotógrafos de câmera na mão e ideias na cabeça. [...]

A pressfotografia era mistificação figueroysta de Jean Manzon. Barreto/Medeiros/Carneiro eram os rossellinis da pressfot. Carneiro/Barreto/Medeiros fotografavam a realidade brasileira, descobrindo a verdadeira imagem do subdesenvolvimento. ${ }^{37}$

No território da canção, as culturas candomblezeira e litorânea encontrarão um correspondente de grande ressonância à literatura de Jorge Amado na obra de Dorival Caymmi, com o lançamento, em 1954, do álbum Canções praieiras. A representação do microcosmo itapuãzeiro, dos usos e costumes do homem litorâneo, ganha uma forma ao

36 TACCA, Fernando Cury. Imagens do Sagrado: Entre Paris Match e O Cruzeiro. Campinas: Ed. da Unicamp/Imprensa Oficial do Estado de São Paulo, 2009. 
mesmo tempo musical e de valor antropológico, pela organicidade com que o lirismo caymmiano penetra no universo místico e na paisagem natural de Itapuã.

Em meio a esse fenômeno da cultura negra baiana, surge ainda uma matriz cinematográfica de grande relevância pelo seu pioneirismo, da qual o maior expoente é o cineasta Alexandre Robatto Filho (1908-1981) com sua obra documental. Na presente análise, procuraremos demonstrar de que forma se estabelece um diálogo estético entre Barravento e parte da obra do documentalista soteropolitano e, mais uma vez, como Glauber Rocha faz uma assimilação crítica da matriz regionalista aberta pelos seus predecessores.

Em Revisão crítica do Cinema Novo, o cineasta fornece uma primeira pista para a investigação desse diálogo:

O fato é que, tendo notícia dos filmes de A. Robatto Filho, o cinema da Bahia viveu e amadureceu de festivais, retrospectivas, palestras e uma intensa crítica liderada por Walter da Silveira: deste núcleo saíram Hamilton Correia, eu, José Gorender e, anos depois, a nova crítica liderada por Orlando Senna e o Grupo Geraldo Portella, [...]. ${ }^{38}$

Alexandre Robatto Filho era um intelectual da classe média soteropolitana oriundo de elites econômicas rurais. Embora dentista de formação, foi um diletante nas artes e um cineasta autodidata. Sua produção cinematográfica começa de forma amadora ainda nos anos 1930 e vai progressivamente se sofisticando na medida em que procura inventariar diferentes dimensões da vida baiana: desde o espaço rural até o urbano, da atividade pecuária ao regresso da Miss Brasil a Salvador. Alguns dos seus títulos são: Desfile dos quatro séculos, Carnaval, Favelas, Exposição pecuária - 1949, A marcha da boiadas, Ginkana em Salvador, O retorno de Martha Rocha, Vistas pitorescas da Bahia, dentre outros.

Sempre ligados ao gênero documentário, seus filmes têm inegável valor histórico na medida em que registram diferentes facetas da atividade econômica e as agitações na vida cultural do Recôncavo Baiano em pleno período de crescimento urbano, passando pela Era Vargas até o desenvolvimentismo da República Populista. ${ }^{39} \mathrm{Com}$ seu

38 ROCHA, Revisão crítica do cinema brasileiro. São Paulo: Cosac \& Naify, 2003. p.154.

39 Os dados biográficos aqui arrolados sobre Alexandre Robatto Filho foram extraídos do documentário: OS FILMES que eu não fiz: Alexandre Robatto Filho, Pioneiro do Cinema na 
interesse pela cultura popular, Robatto Filho se liga intimamente ao círculo intelectual de Jorge Amado e chega a trabalhar em parceria com Carybé, conforme veremos mais adiante.

Quando Roberto Pires, Luiz Paulino dos Santos, Glauber Rocha e Trigueirinho Neto começam a produzir sua cinematografia, constituindo o chamado "Ciclo Baiano do Cinema", ${ }^{40}$ Robatto Filho já contava com uma filmografia extensa, o que nos leva a indagar que tipo de relação é travada entre o cineasta mais experiente e os jovens estreantes. No que diz respeito a Glauber Rocha o contato foi importante mas breve: segundo José Gatti, Robatto era dos poucos que contavam à época com equipamento de filmagem profissional e teria se negado a emprestá-lo a Glauber para as filmagens de Barravento, o que ocasionou uma ruptura abrupta e definitiva das relações entre ambos. ${ }^{41}$

Ainda assim, dentro da prolífica obra de Robatto Filho podemos destacar três curtas-metragens que vão encontrar ressonância formal e crítica nas experiências cinematográficas de Glauber Rocha e de seus contemporâneos, tanto pelo viés etnológicodocumental na composição do repertório imagético quanto pela construção de uma narrativa fílmica em torno do regionalismo praieiro. São eles, respectivamente, Entre o mar e o tendal (1952-53), Xaréu (1954) e Vadiação (1954). ${ }^{42}$

O primeiro dos três cronologicamente, Entre o mar e o tendal, é um curtametragem preto-e-branco com cerca de 22 minutos, filmado em $16 \mathrm{~mm}$ entre os anos de

Bahia. Direção: Petrus Pires. Bahia: Estúdio Sonia Robatto e Iglu Filmes, 2012. 1 curta metragem (26 min.), colorido.

A expressão refere-se ao surto de produção cinematográfica na Bahia entre 1958-1964 e é empregada por Maria do Socorro Silva Carvalho em: A nova onda baiana: cinema da Bahia (1958-1962). Salvador: EDUFBA, 2003. Após a recusa e o desentendimento, Glauber teria afirmado em artigo que Robatto "já tinha dado o que devia no cinema, e que a única contribuição que ele poderia dar seria o filme que Glauber iria fazer no enterro dele”. apud GATTI, Barravento: a estreia de Glauber. Florianópolis: Ed. da UFSC, 1987, pp.24-25.

Todos os documentários aqui analisados foram consultados na Cinemateca Brasileira, em São Paulo. Vadiação é o único deles que pode ser encontrado integralmente na Internet. Disponível em: https://www.youtube.com/watch?v=zYH7WDoUdOE https://www.youtube.com/watch?v=ObGj2e2bsAc. Acesso em 17 julho 2020. Algumas cenas de Entre o mar e o tendal e Xaréu podem ser conferidas no documentário biográfico de Robatto Filho referido logo acima, na nota de número 39 , e está disponível em: https://www.youtube.com/watch?v=_S8ifaFe9yE. Acesso 17 de julho 2020. 
1952 e 1953. Trata-se de uma produção financiada pela Diretoria de Arquivo e Divulgação de Salvador que tematiza a pesca de xaréu nas praias de Chega-Nego e Carimbamba, imediações de Itapuã. O título faz referência aos dois núcleos do trabalho pesqueiro: o tendal é um espaço de reserva e preparação, um tipo de barracão instalado na praia onde os pescadores vão consertar as redes danificadas periodicamente pela intensa dinâmica do trabalho ou pelos próprios peixes; o mar é, evidentemente, o local da performance, da realização da potência de trabalho e do embate entre o homem e a natureza.

Tendo em vista que o homem praieiro atribui a essa natureza um valor espiritual, o mar torna-se também um espaço de manutenção da fé, no caso, candomblezeira. De forma que o binômio mar-tendal alude ao caráter cíclico do modo de vida tradicional da pesca, a dinâmica pendular, ora mais ora menos harmônica, entre a força da natureza e o artifício humano. A preposição "entre" evoca a ideia de um espaço restritivo de ação do indivíduo, isto é, apesar da vastidão da paisagem o pescador está enquadrado por um rigoroso regime laboral. Em uma chave muito irônica, a personagem Firmino, de Barravento, faz referência a esse modo de vida repetitório: "Tá com inveja? Você não tem nada pra contar. A vida aqui não muda nunca, é sempre no puxa-puxa."

Ao longo de todo o documentário ouve-se a narração declamatória de Alfredo de Almeida. A constância dessa elocução cria uma instância mediadora entre o espectador e a imagem. Isto é, a presença narrativa faz com que passemos a acessar a imagem em conjunto com a construção poética da linguagem. Logo, o narrador estabelece uma hierarquia entre o discurso e o fenômeno social, na qual prepondera seu próprio viés interpretativo: a voz encarna o observador intelectualizado diante do fenômeno antropológico, que se torna pretexto para a sua elaboração discursiva poética.

Esse narrador erudito descreve a princípio a paisagem característica do litoral nordestino a partir de uma imagem das mais icônicas, o coqueiro. Na primeira sequência, a câmera avança em lento travelling por entre um coqueiral, e depois, dirige-se para um céu entrevisto pelas copas das árvores com um giro vigoroso no instante mesmo em que a narração evoca a dança popular da população local: "o esbelto ornamento que tudo envolve no giro das palmas incansáveis".

O movimento de câmera e a narração desenham uma correlação entre a paisagem e as manifestações populares locais, determinando desde já uma ligação simbólica entre a cultura do indivíduo local e seu meio, o que será reforçado mais adiante pela descrição 
da prática pesqueira. ${ }^{43} \mathrm{O}$ discurso e a montagem fílmica criam um continuum antropocêntrico, onde a paisagem natural serve de decoração ("o esbelto ornamento") à paisagem humana, enquanto a câmera anima uma ligação entre o solo e o céu.

Em seu estudo analítico de Barravento,${ }^{44}$ Ismail Xavier referiu-se à forma com que Glauber utiliza um movimento de câmera semelhante em pelo menos dois momentoschave do filme:

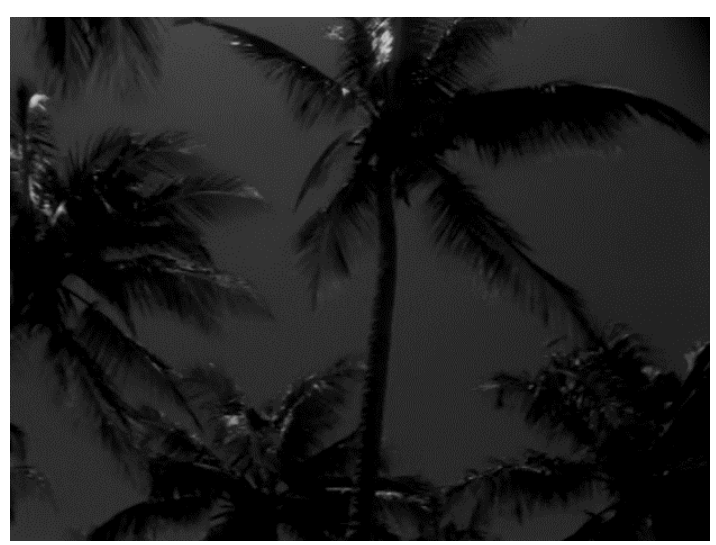

1 - Ouve-se os batuques do barracão.

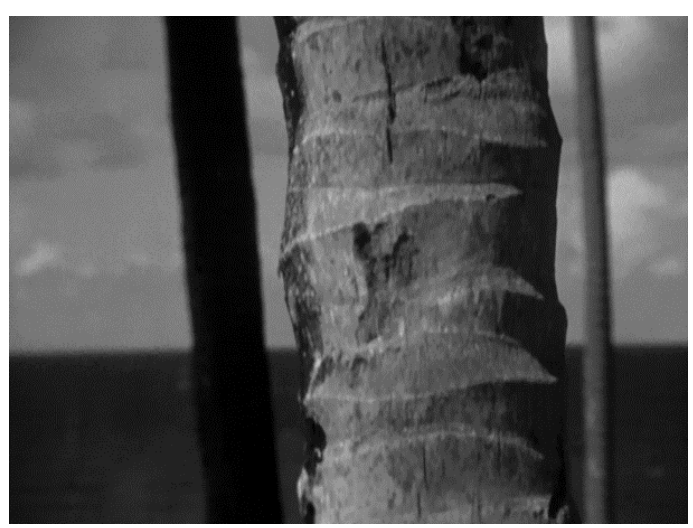

$1 \mathrm{~b}$ - Aruan foi dessacralizado. A câmera sobe pelo tronco do coqueiro até a copa.

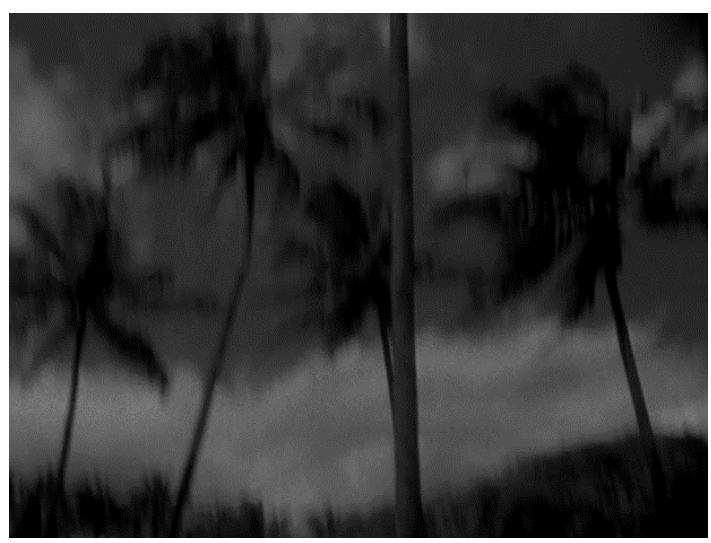

2 - A câmera desce rapidamente pelo tronco do coqueiro para o chão onde se encontra $o$ despacho de Firmino.

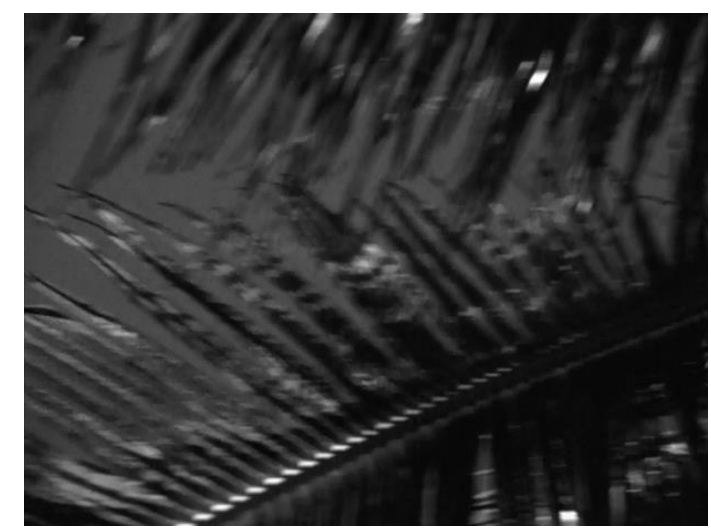

$2 b$ - Vê-se depois o céu. O barravento estoura.

43 Não seria exagero dizer que a estrutura implícita "Terra", "Homem”, com sua carga histórica, geográfica e antropológica, associada a uma narração grandiloquente, de uma verborragia entre descritiva e poética, seriam em alguma medida um decalque d'Os Sertões, de Euclides da Cunha. Não se tratava de um autor estranho ao repertório de Robatto já que, alguns anos antes, em 1949, um excerto d'Os Sertões já fora epígrafe do documentário Um milhão de KVA.

44 XAVIER, Ismail. "Alienação versus identidade” in Sertão mar: Glauber Rocha e a estética da fome. São Paulo: Duas Cidades; Editora 34, 2019. p.25-59. 
No primeiro deles, a câmera registra o céu e as copas dos coqueiros e desliza para o ebó de Firmino, logo após tê-lo acompanhado para dentro do mistério da casa de Pai Tião. Sugere-se que o malandro teria assim tentado, em vão, mobilizar as forças cósmicas para mudar o curso harmonioso do destino de Aruan. Dessa vez ele fracassa, mas a segunda vez em que a câmera reitera esse movimento, em sentido inverso, é para registrar a quebra da virgindade do jovem e o despertar fálico de sua força viril.

Essa observação demonstra em ambos os diretores uma tendência ao uso da movimentação da câmera para projetar na estrutura fílmica relações de causa e consequência entre o plano das ações humanas e a paisagem natural, tornando-a um ente personificado que interage com a cultura, a tal ponto que não possamos separar natureza e espiritualidade, as formas ambientais das formas da cultura.

Após o sobrevoo geográfico inicial sobre o litoral baiano e a sequência dos coqueiros, o narrador de Entre o mar e o tendal faz um recuo histórico: segundo nos informa, a região onde residem os pescadores de xaréu fora outrora ocupada por fazendas de coco - árvore oriental aclimatada com grande sucesso na costa nordestina. A essa época vicejava uma economia extrativista, a caça de cachalotes com fins de obtenção do óleo de baleia. A caça intensiva teria afugentado as baleias da região e os pescadores remanescentes passariam a empregar a sua expertise do mar na pesca do xaréu. Isso evidencia, do ponto de vista econômico, o declínio da dinâmica de produção extrativista na região e a marginalidade dessas populações para as quais o xaréu foi uma reconversão urgente, já que não houve plano de reinserção de sua força de trabalho.

Odorico Tavares, na fotorreportagem d'O Cruzeiro de que falamos ("A pesca do xaréu"), reconstitui brevemente o histórico do universo pesqueiro no litoral da Bahia adotando um viés ligeiramente distinto daquele do documentário, porque relembra também a ligação entre as formas de trabalho dos pescadores e a dinâmica de exploração do regime escravista que vigorou na região:

A pesca de xaréu é um episódio de trabalho, de canseiras, mas, como todo episódio árduo da vida dos negros baianos é também de poesia, de música e de baile. De outubro a abril, os xaréus vão para o norte em grandes cardumes para a desova, procurando climas mais quentes para o cumprimento de sua missão procriadora e é nesta época, que os pescadores das praias dos subúrbios de Salvador lançam-se à sua tarefa. 
Em Chega Negro, Carimbamba e no Saraiva cumprem os mesmos trabalhos dos seus antepassados, trabalhos que vêm dos tempos da Colônia, do Império, da República até nossos dias. Frederico Edelweiss nos relembra que o nome de Chega Negro vem dos gritos dos senhores, chamando os negros escravos para puxarem as redes do xaréu. ${ }^{45}$

O filão histórico que liga a presença da população negra e sua pobreza material ao passado escravocrata é um dado ora negligenciado ora romantizado pelo documentário de Robatto, mas será o ponto de partida para gerar em Barravento um dado crítico contundente que dá o tom dos discursos do filme. No letreiro inicial lê-se: "No Litoral da Bahia vivem os negros pescadores de 'xaréu', cujos antepassados vieram escravos da África". Mais adiante Firmino diz a Cota: "Pra mim, Princesa Isabel é ilusão.” E depois é a vez de Aruan: "Viemos de lá escravos mas a escravidão já acabou.” No final do filme, Firmino exclama: “O Mestre é um escravo!".

Pode-se dizer que Barravento, ao reiterar a natureza histórica da realidade social e econômica dos pescadores tem sempre um espelho em retrospecto voltado para a questão da escravidão e de seus efeitos como origem das condições do trabalho contemporâneo, o que resulta em uma perspectiva crítica. Robatto Filho, por outro lado, constrói a correlação entre discurso e imagem tendo como princípio orientador o mito, a fabulação e a idealização tanto da realidade retratada quanto da linguagem.

Isso explica o teor romântico e um tanto euclidiano com que o documentário aborda a ancestralidade do homem praieiro, muito distinto daquele adotado por Barravento: "homens de ébano relembrando as proezas dos tios africanos". Nessa construção poética há um esforço de fabulação que, se por um lado idealiza a realidade do trabalho, tornando-o acontecimento épico (proeza), por outro suprime toda a tensão

45 TAVARES, Odorico. Bahia: imagens da terra e do povo. Rio de Janeiro: Civilização Brasileira, 1964, p.66. Observe-se que há alguma oscilação relativa ao período da pesca entre o artigo de Odorico e o documentário de Robatto, segundo o qual, o peixe oriundo do litoral sul do Brasil volta da desova passando pelo Recôncavo Baiano somente em meados de fevereiro. Se é exata, a informação do documentarista nos permitiria talvez situar a trama de Barravento no mês de fevereiro, que é coincidentemente o mês do candomblé consagrado ao Orixá tantas vezes referido no filme, Iemanjá (embora saibamos que as filmagens se tenham desenrolado entre os meses de outubro e dezembro de 1960). 
histórica do passado escravista, afinal, os "tios africanos" evocam uma familiaridade tribal e pacífica.

Em outros momentos ainda, a narração produz fórmulas retóricas que misturam uma cosmovisão trágica da vida dos pescadores com o sentido do trabalho - "congelados pela sombra fatalista de uma atividade vetusta e tradicional" - e resvala em uma concepção de destino cujos termos fazem lembrar o letreiro de Barravento: "este povo é dominado por um misticismo trágico e fatalista."

No limite, a idealização romântica do discurso no documentário criará fórmulas ingênuas como: "O cabo [da rede] prende por um instante a gente mais livre do mundo" e "E eles são muito felizes, porque passam a existência alegremente toda vivida entre o mar e o tendal." De modo que a preponderância do discurso falado em Entre o mar e o tendal, ao criar uma instância poética dominante que soterra as imagens, desnaturaliza a força estética do fenômeno social, traindo em alguma medida o interesse documental de retratar a realidade praieira. Prova disso é, por exemplo, a estranheza que causa a evocação de imagens cristãs pelo narrador ao fim do documentário, associando os pescadores a apóstolos, dentro de um universo eminentemente candomblezeiro.

Xaréu, por sua vez, o curta-metragem que sucede Tendal, já demonstra uma construção formal e discursiva mais ousada e um experimentalismo que se aproxima do estilo glauberiano. O filme, que tem duração de apenas 9 minutos, é nas palavras do próprio Glauber Rocha, a "remontagem estetizante"46 de algumas sequências do documentário anterior: a narração grandiloquente se rarefaz, dando lugar a uma banda sonora mais atuante, composta inteiramente por cânticos de Aruanda (performados por Semíramis Seixas e o Coral Ceciliano).

Assim como em Barravento, o resultado dessa correlação mais orgânica entre o som e a imagem gera a ampliação do espaço de representação da cultura local, e por consequência, a sua autonomia estética liberada do discurso externo exotizante. Isso porque essas canções têm uma maior verdade antropológica, são realmente entoadas durante o trabalho da puxada e compõem a atmosfera laboral. Cabe lembrar que Barravento leva ainda mais longe a importância do som local na construção da diegese fílmica já que, não apenas Glauber Rocha suprime completamente qualquer trilha sonora comentativa, como passa a articulá-la com a própria montagem, fazendo da banda sonora, mais do que um ambiente, um campo de debate crítico com a imagem.

$46 \quad$ ROCHA, Revisão crítica do Cinema Novo, p.153. 
No que diz respeito à estrutura das canções, é sempre reiterativa: há um estribilho introduzido pelo cantador, seguido pelo coro coletivo que responde ou repete o tema. $\mathrm{O}$ ritmo ritualístico e cíclico da canção de trabalho faz ecoar na dinâmica da puxada, a cultura religiosa candomblezeira, unindo a comunidade em um sentido de imersão coletiva nos seus próprios ritos fundadores. Em suma, diminui-se a presença do intérprete erudito, a realidade local vem para o primeiro plano e se impõe com mais completude, na sua própria força estética.

O primeiro dos cânticos de Xaréu (também presente em Tendal) é o mesmo que, em Barravento, acompanha a chegada do personagem Aruan: "Quando venho d'Aruanda, eu venho só / Só, só, eu venho só / Eu lá deixei mãe, eu lá deixei vó, etc”. Seguem-se batuques e pontos de Orixás, dentre os quais Iansã: “Oyá Oyá, ela é dona do mundo / Oyá oyá, ela já venceu guerra." Vale lembrar que, segundo a mitologia iorubá, Iansã/Oyá é o Orixá feminino associado, entre outros elementos, às ventanias e tempestades. ${ }^{47}$ É uma divindade aguerrida e de caráter feroz. Curiosamente, um dos toques de atabaque que a acompanha dentro da ritualística do candomblé se chama barravento.

A interação entre som e imagem enfatizada pelos cantos cria uma narrativa subjacente que sublinha a presença da matriz africana na cultura praieira, preservando o viés mitificante da ancestralidade que já fora prenunciado por Tendal. A pouca narração de Xaréu caminhará no mesmo sentido.

Ela está resumida a dois blocos, um no princípio e outro na conclusão da película, emoldurando-a:

Bloco 1: No litoral da Bahia muitos descendentes de antigos pescadores africanos ainda continuam com as práticas primitivas mantidas pela tradição. Essa gente humilde e vigorosa nos permite uma visão do passado nos atos mais singelos da mais poética das profissões.

Bloco 2: O progresso virá. Virão fatalmente os métodos modernos e as velhas canções se perderão no ronco dos motores. Ficará, porém, naquelas praias, a lembrança de uma gente alegre que trabalha cantando.

47 VERGER, Jean-Pierre. Orixás: deuses iorubás na África e no Novo Mundo. (trad. Maria Aparecida de Nóbrega). Salvador: Corrupio, 2002. 
Pode-se perceber que, apesar do aprofundamento na complexidade da representação do homem praieiro, ainda subsiste, no bloco 1 sobretudo, a interferência do discurso externo que romantiza o seu modo de vida.

Entretanto, o segundo bloco agrega algo de novo, um princípio de tensão: a percepção de que esse modo de vida caminha para o desaparecimento. Não há maiores detalhes mas, por volta desse instante, vê-se desde a praia uma estrada, símbolo do progresso desenvolvimentista e da modernidade. O narrador prenuncia um processo histórico: a crescente expansão demográfica de Salvador vai pouco a pouco aglutinar o espaço provinciano de Itapuã, até então uma praia retirada, refúgio de antigas tradições.

Em Barravento essa tensão é elevada pela chegada do malandro em Buraquinho. Firmino, outrora pescador, tornou-se um homem transfigurado pela experiência contundente do centro urbano e vem desmantelar o equilíbrio da pacata província, expondo suas contradições internas: segundo seus princípios a paz provinciana é passividade, e a beleza dos ritos, alienação e fatalismo. A incursão do malandro urbano no estagnado universo praieiro é, em alguma medida, a invasão da cidade sobre o reduto regional que o documentário de Robatto prenunciara; contudo, enquanto em Xaréu o tom é sobretudo nostálgico, em Barravento a modernidade tenta se impor sobre a comunidade, pela violência, pelo discurso e corrói a própria linguagem fílmica.

Em certa medida, a função crítica do discurso de Firmino vai em duas direções: é intradiegética porque alimenta os acontecimentos do enredo, e extradiegética porque se dirige à própria representação exotizante do mundo praieiro. Glauber incute dentro do enredo uma personagem cujo discurso rebate a poesia e o encantamento do narrador robattiano, para lembrar-nos a todo tempo a calamidade da pressão econômica e das dinâmicas de exploração modernas sobre os modos de produção tradicionais.

De modo a aprofundar o debate crítico na forma, Glauber Rocha faz uma série de decalques do repertório visual de Robatto Filho. Observem-se os fotogramas a seguir: 

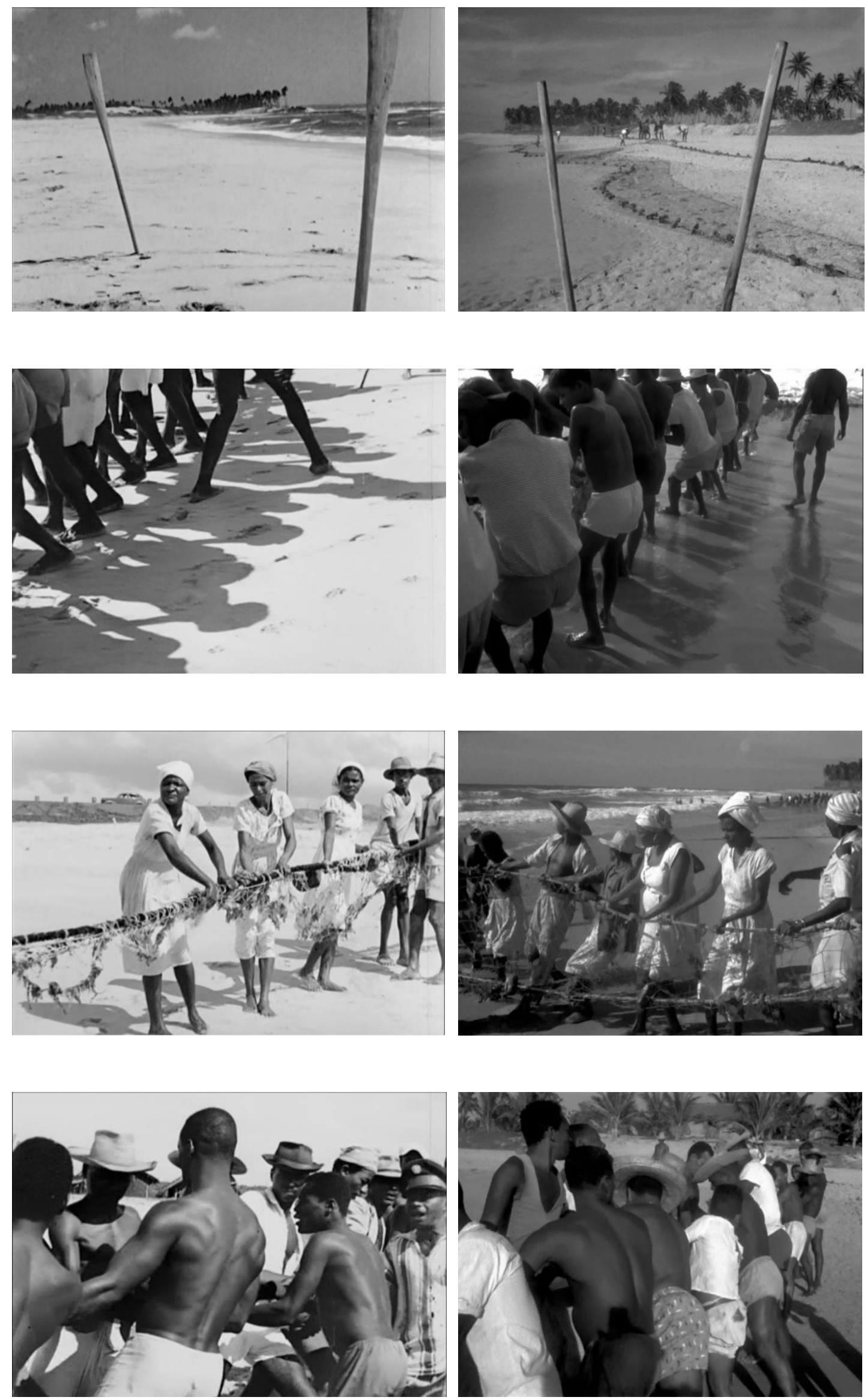

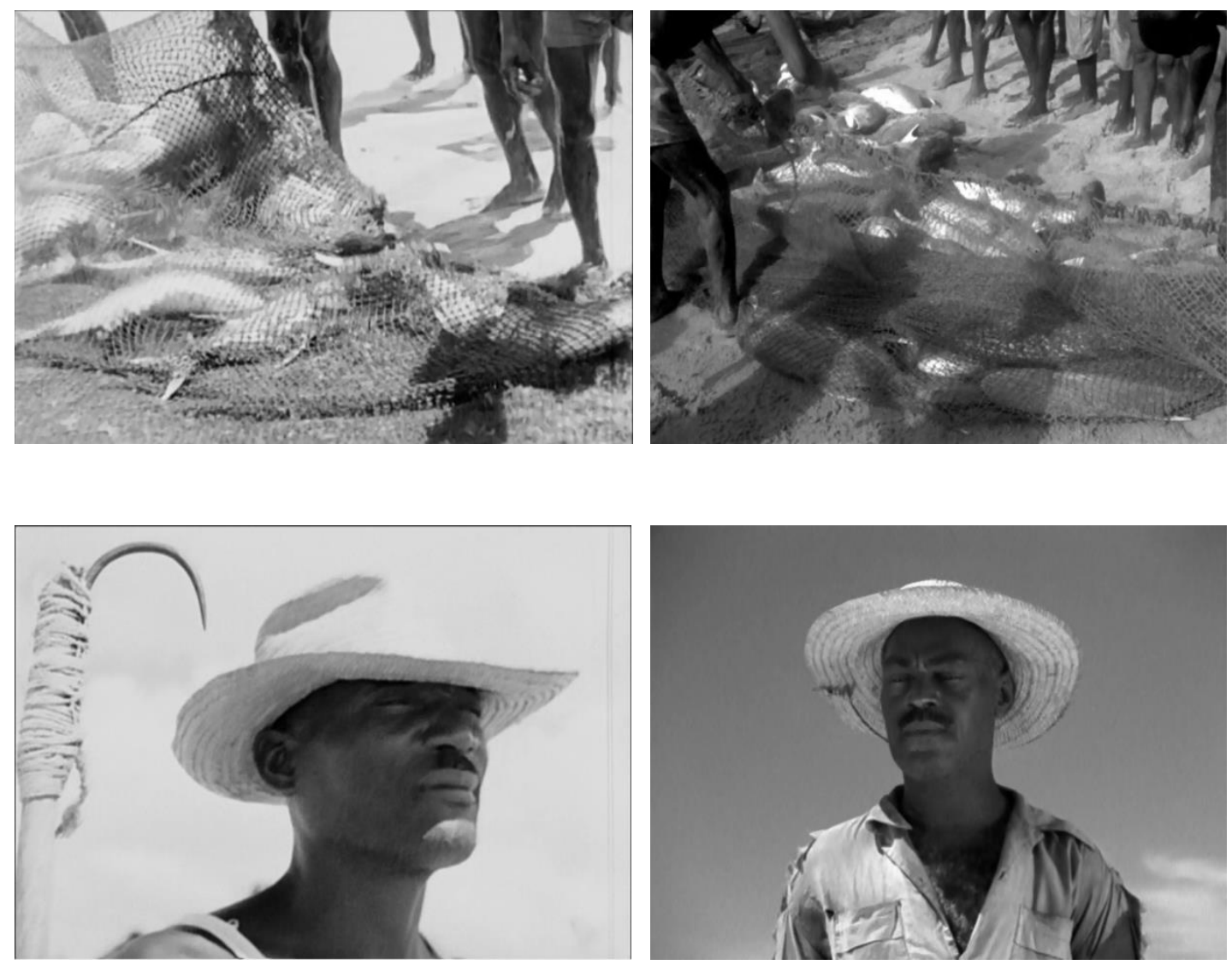

Ao que parece, essas rimas visuais não passaram despercebidas a Robatto Filho. Segundo testemunho de uma de suas filhas, Sônia Robatto, no documentário Os filmes que eu não fiz (2013), ${ }^{48}$ a semelhança o teria irritado. Para além da temática, os fotogramas revelam uma série de paralelismos no tratamento do objeto: a representação do trabalho coletivo. O enquadramento, o posicionamento de câmera, a ênfase na interação entre o movimento rítmico, o gesto e a luz natural criam uma poesia visual em torno do aspecto coreográfico da pesca.

Se por um lado as semelhanças refletem uma inspiração evidente por parte de Glauber Rocha, é nas diferenças que encontramos a ruptura com um certo registro narrativo canônico de Robatto Filho. Ao apropriar-se de elementos do regime documental em uma obra de ficção, Glauber está criando uma forma descontínua, fragmentária, que aponta para os limites críticos e simulacros da representação tradicional. Isto é, o esvaziamento do viés romântico do regionalismo praieiro se dá pela imposição da Petrus Pires. Bahia: Estúdio Sonia Robatto e Iglu Filmes, 2012. 1 curta metragem (26 min.), colorido. 
consciência histórica, da metropolização, do acirramento das tensões sociais na passagem dos anos 1950 que coloca em xeque o posicionamento do artista:

Poderia haver poesia no Brasil, se a cada instante alguém tomba em feridas, outro desmaia com o estômago deserto? Acredito que esta pergunta seja cruel para nós todos, para os poetas, artistas e para os políticos. Poderemos, sem vergonha, empresar o exotismo da bela Bahia, procurando os ritmos do xaréu, os mistérios dos candomblés, a plasticidade da invasão? Aí não está nenhuma estética. Aí reside uma profunda imoralidade. [...]

Sem nenhuma vergonha e exposta a todos, digo humildemente que poderia fazer de "Barravento" um poema do mar, coqueiro, aurora e exotismo. E de amor. Mas fiz, deliberadamente, uma fotografia da miséria. ${ }^{49}$

Daí compreendemos a carga crítica do termo “estetizante” que Glauber associou ao documentário de Robatto Filho. O uso intermitente do documentário como uma unidade narrativa entre outras não produz um efeito imersivo, onde a linguagem poética vem para o primeiro plano idealizando a realidade local, mas uma irregularidade estética que incorpora, na própria estrutura do filme, o atrito que está em curso entre o modo de vida da província e a violência do fenômeno urbano, cujo porta-voz é Firmino.

O último dos documentários de Alexandre Robatto Filho de que trataremos na presente análise é Vadiação. Embora seja contemporâneo a Xaréu, distingue-se pelo caráter mais artesanal no arranjo dos elementos fílmicos, desde a montagem até a preparação do campo, conforme demonstraremos.

Trata-se de um curta-metragem filmado em $16 \mathrm{~mm}$, preto e branco, 8'14" de duração. Realizado em 1954, Vadiação conta com as importantes colaborações do artista Carybé, autor dos 4 letreiros iniciais, dos berimbaus e cantores de Mestre Bimba e jogadores do Mestre Valdemar. O tema é a capoeira, o que transfere o núcleo do interesse documental para a cultura negra urbana, diferentemente dos curtas de que falamos anteriormente. A essa época, os círculos de capoeira estavam organizados em núcleos

49 ROCHA, Glauber. "Experiência Barravento: confissão sem moldura". Diário de Notícias de Salvador, Salvador (BA), 25-26 dezembro 1960. 
regionais em Salvador, conforme referido por Odorico Tavares em outra de suas fotorreportagens baianas, "Capoeira":

Se o visitante quer assistir ao jogo de capoeira, há, hoje, mais de um barracão onde pode ir. O de Juvenal no Chame-Chame, o de Pastinha, no Pelourinho, o de Canjiquinha, no Turismo, o de Mestre Bimba, no Alto de Amaralina, o de Valdemar, no Corta-Braço. ${ }^{50}$

Além de fornecer a música, o Mestre Bimba figura no documentário de Robatto Filho, assim como Canjiquinha é personagem e voz em Barravento. Por um lado, a incorporação de não-atores organicamente ligados à capoeira e ao candomblé (Mãe Dadá) revela mais uma vez a absorção do elemento documental pelo registro da ficção, o que atribui maior legitimidade à representação da cultura praieira, mas, por outro, demonstra um afastamento do tipo de retrato pitoresco e caricatural que o cinema brasileiro fazia da cultura negra até então. ${ }^{51}$

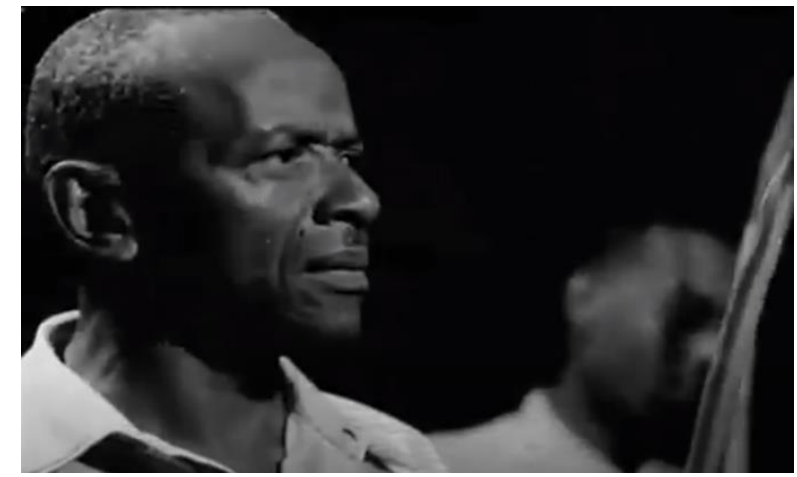

1 - Mestre Bimba em Vadiação.

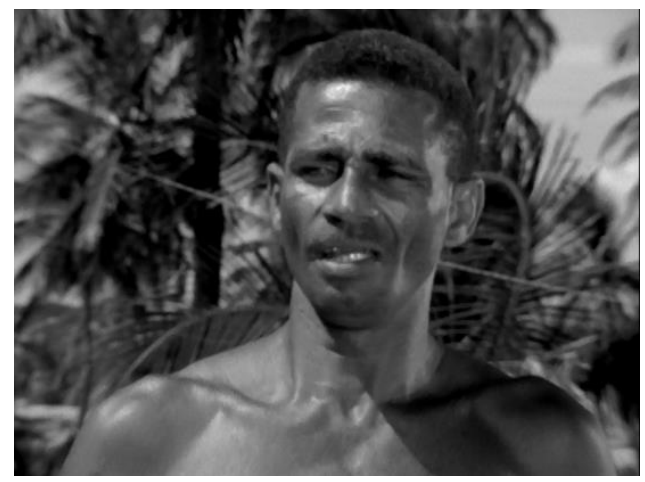

2 - Mestre Canjiquinha em Barravento.

Vadiação é introduzido por uma espécie de letreiro contextual que substitui o narrador grandiloquente de Tendal e Xaréu. Encontramos o mesmo apelo ao texto escrito no "avant-propos" de Barravento, em ambos os casos com uma síntese alusiva à situação histórica da população negra, procurando dar causas e efeitos às feições de suas manifestações culturais: a capoeira e o candomblé. Segundo o informativo de Vadiação, a capoeira seria uma luta que camufla no ritmo de dança a resistência potencial dos negros

50 TAVARES, op. cit., p. 175.

51 STAM, Robert. Multiculturalismo tropical, um História Comparativa da Raça na Cultura e no Cinema Brasileiros. Trad. Fernando S. Vugman. São Paulo: Edusp, 2008. 
à opressão policial. No caso de Barravento, o candomblé seria uma força alienadora da consciência da miséria e marginalização dos negros. Em um e outro caso, a manifestação cultural é em alguma medida entendida como materialização de uma exploração sublimada.

Do ponto de vista da apresentação, no documentário, o letreiro introdutório não está dissociado das imagens, mas sobreposto aos primeiros quadros, estabelecendo desde o princípio um jogo gráfico entre texto e figuração.

Observemos os três quadros a seguir:

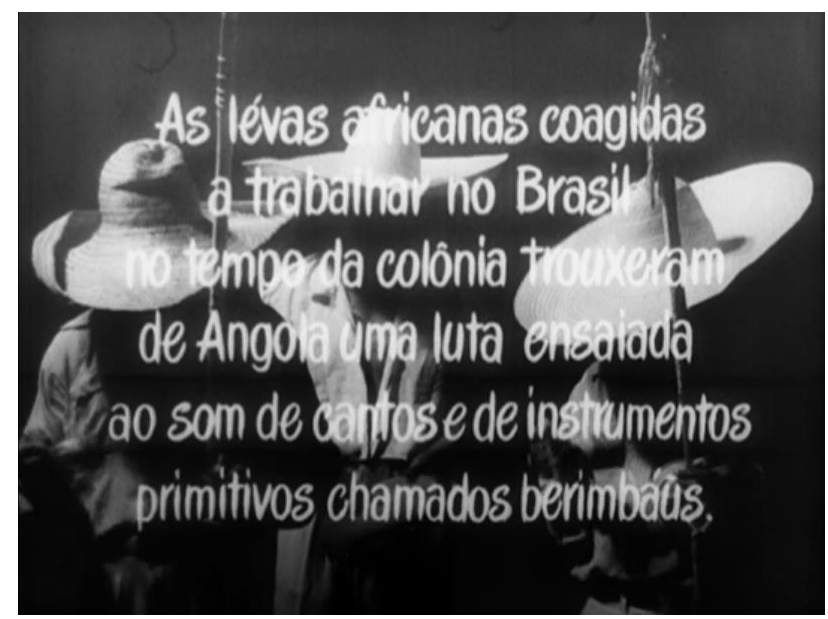

Quadro 1: As levas africanas coagidas a trabalhar no Brasil no tempo da colônia trouxeram de Angola uma luta ensaiada ao som dos cantos e de instrumentos primitivos chamados berimbaus.

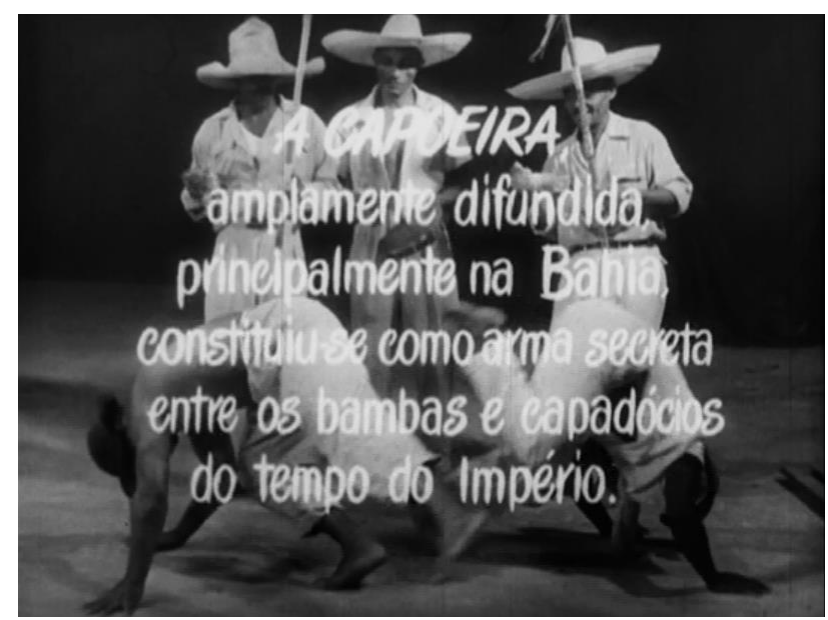

Quadro 2: A CAPOEIRA, amplamente difundida principalmente na Bahia, constituiuse como arma secreta entre os bambas e os capadócios do tempo do Império. 


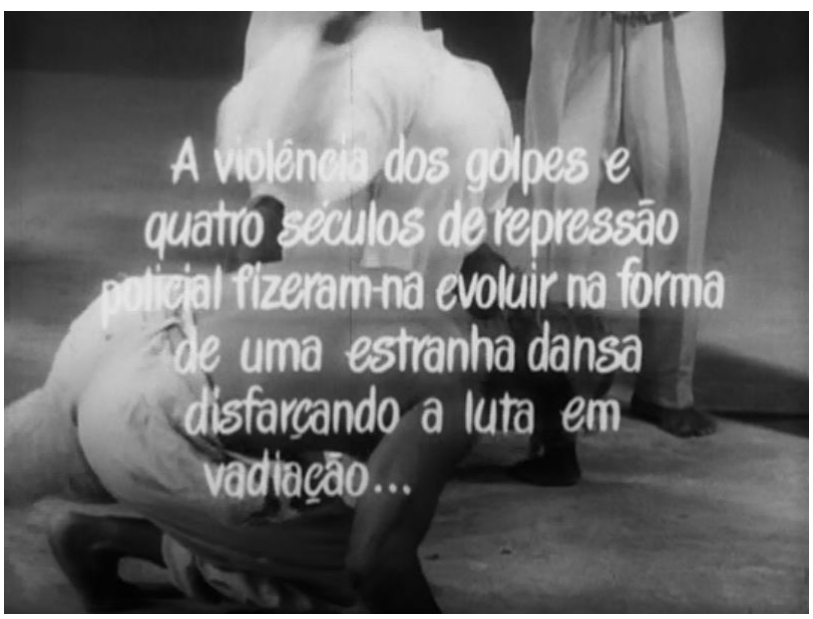

Quadro 3: A violência dos golpes e quatro séculos de repressão policial fizeram-na evoluir na forma de uma estranha dansa (sic) disfarçando a luta em vadiação...

Enquanto elemento informativo e contextual, a introdução de Vadiação se afasta da idealização romântica criada pela narração nos documentários precedentes. Ao contrário, a tensão crítica sobe ligeiramente ao apresentar a capoeira a partir de sua função social, e em perspectiva com a violência urbana institucionalizada pela polícia.

Na medida em que esse elemento textual se desenrola, a câmera em lento recuo registra uma evolução coreográfica com a multiplicação de elementos no quadro: primeiro se vê o chapéu de abas largas de um tocador nas sombras, depois os três tocadores são enquadrados. Em seguida, os tocadores estão sob a luz que permite distinguir suas expressões, entram dois jogadores de cada lado do plano. A câmera muda de posição para registrar a movimentação dos corpos, volta para os tocadores, e assim por diante. Os elementos vão se agregando de modo a compor um "teatro da capoeira", corporificando alegoricamente o que o letreiro apresenta como um discurso da história.

Ao longo do documentário, a alternância entre a captação do conjunto e do detalhe estabelecem uma dinâmica pendular: os planos são mais abertos quando se trata de registrar a variedade da interação coletiva, os sentimentos da audiência ora concentrada ora descontraída, e mais fechados sobre os jogadores ou instrumentistas, quando entra em cena a interação dos corpos, a sutileza e flexibilidade do gesto, chegando a enquadrar em alguns momentos o detalhe das mãos percutindo os instrumentos.

Como se pode perceber, há uma predominância do caráter descritivo, a câmera simula um ponto de vista que oscila entre o apelo estético do conjunto e a recolha da minúcia. Há, contudo, alguns instantes de mergulho subjetivo: 


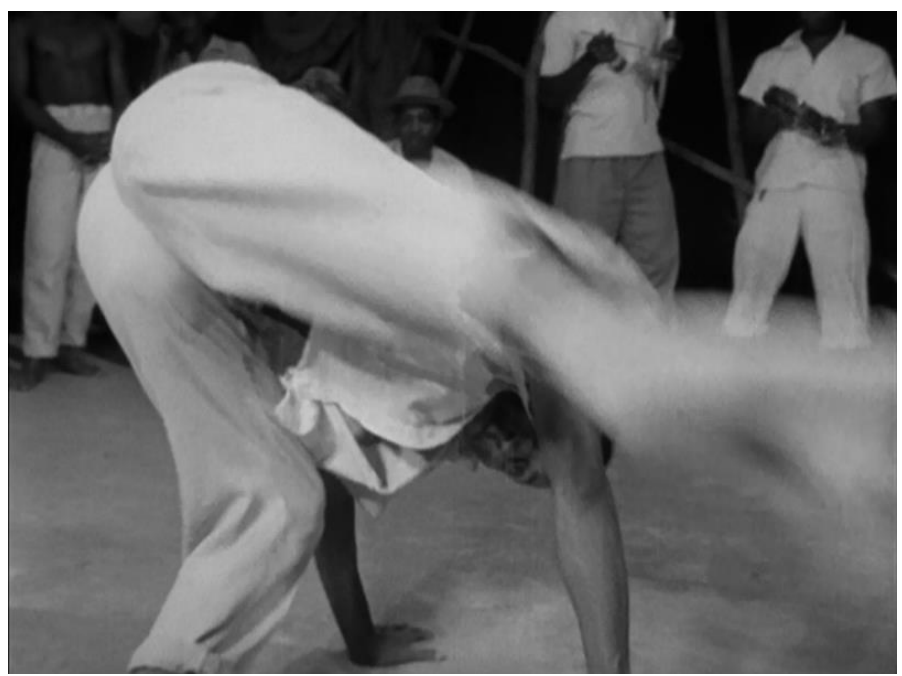

O quadro acima é de um momento em que a câmera focaliza em primeiríssimo plano, assumindo uma posição mais rasteira que transporta o olhar para o centro da performance, como se fizesse o papel de oponente do jogador. No fim do documentário, ela volta a assumir essa posição baixa, em um travelling que recua para fora do círculo dos jogadores, concluindo seu registro. São curtos momentos de ruptura do descritivismo em que a imagem abandona uma alteridade passiva de observador para uma alteridade ativa de participante. Contudo, apesar do alcance subjetivo desse recurso, ele não prevalece no conjunto.

Toda a ação transcorre dentro de um barracão cenografado. A preparação de luz e a disposição premeditada tanto dos elementos cênicos quanto das pessoas acentuam o feitio teatral da ação, que cria momentos distintos ao longo do documentário. Pode-se discernir pelo menos quatro momentos de duração variável:

a) Créditos iniciais com ilustrações de Carybé.

b) Evolução dos primeiros planos, primeiro jogo de capoeira.

c) Foco sobre Mestre Bimba e seus instrumentistas.

d) Último jogo de capoeira e saída.

Essas unidades de sentido são delimitadas pela continuidade da música. $\mathrm{Na}$ transição entre b) e c), por volta dos 5'53", há um expediente técnico que chama a atenção: na transição de uma cantiga para a outra produz-se um breve hiato que é ilustrado filmicamente por um efeito visual semelhante a um abrir e fechar de cortinas. Em seguida, começa a última evolução coreográfica em um espaço modificado, contra um fundo branco. $\mathrm{O}$ contraste entre os corpos e o segundo plano cria um fator gráfico que evoca os 
letreiros iniciais de Carybé, ligando o princípio ao fim da película. A coerência da forma pode-se explicar pelo fato de o artista argentino ter sido responsável pelo desenho dos storyboards. Com efeito, isso explicaria o ritmo diferenciado da filmagem e o aspecto pictórico do conjunto se comparado a Tendal e Xaréu.

O pendor poético e etnográfico dos documentários anteriores dá lugar a um elemento gráfico em Vadiação. Digamos que há uma hibridização da câmera de Robatto com os aspectos visuais que caracterizam o estilo de Carybé: o equilíbrio gestual, as linhas de ação das silhuetas, a sugestão, a composição de cena. Por estarem animados cinematograficamente, extraídos de seu contexto externo, esses elementos de estilo enfatizam os aspectos cênicos, teatrais e performativos da capoeira.

É justamente a forma como Vadiação expõe uma percepção estética e coreográfica da capoeira que Barravento incorpora.

Vadiação
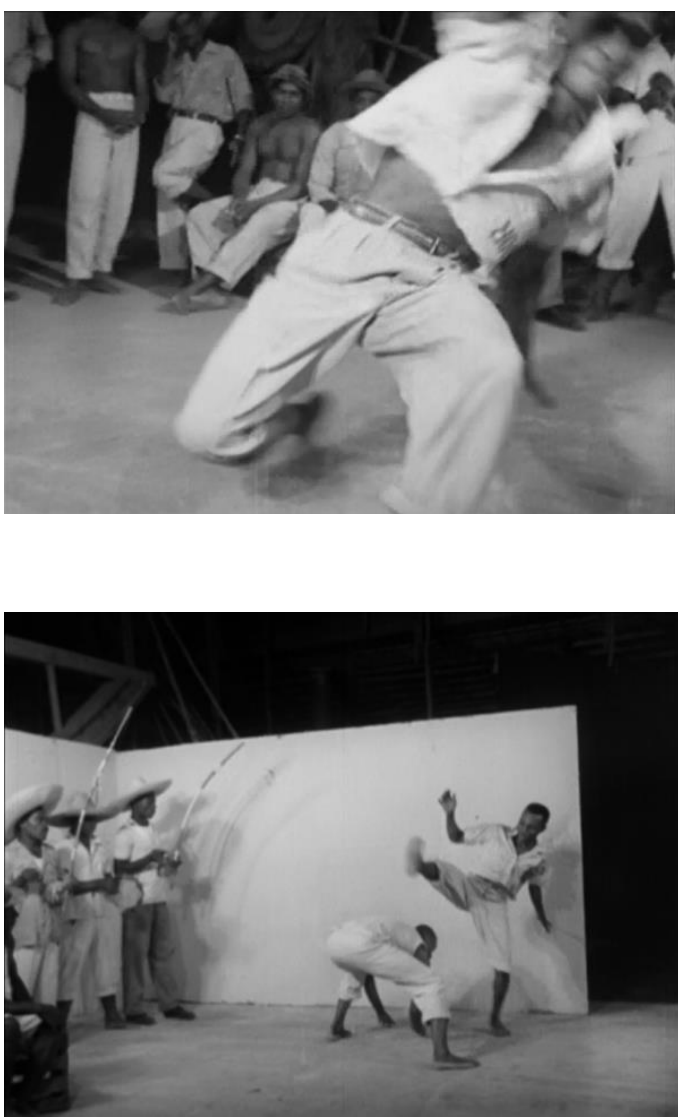

\section{Barravento}
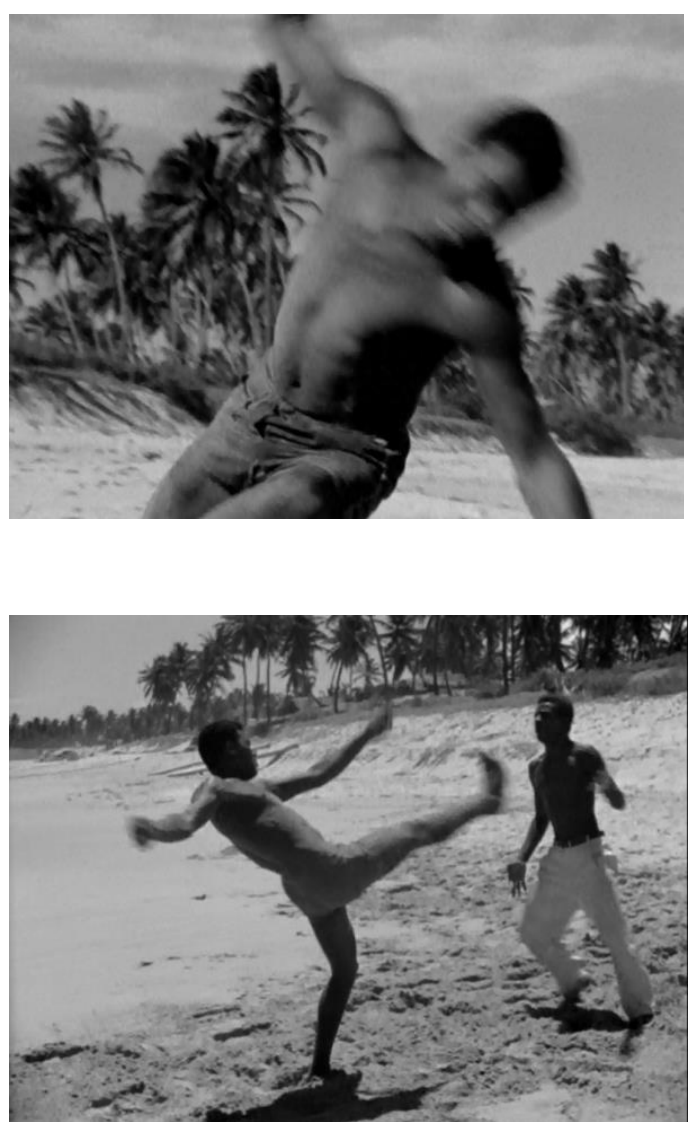

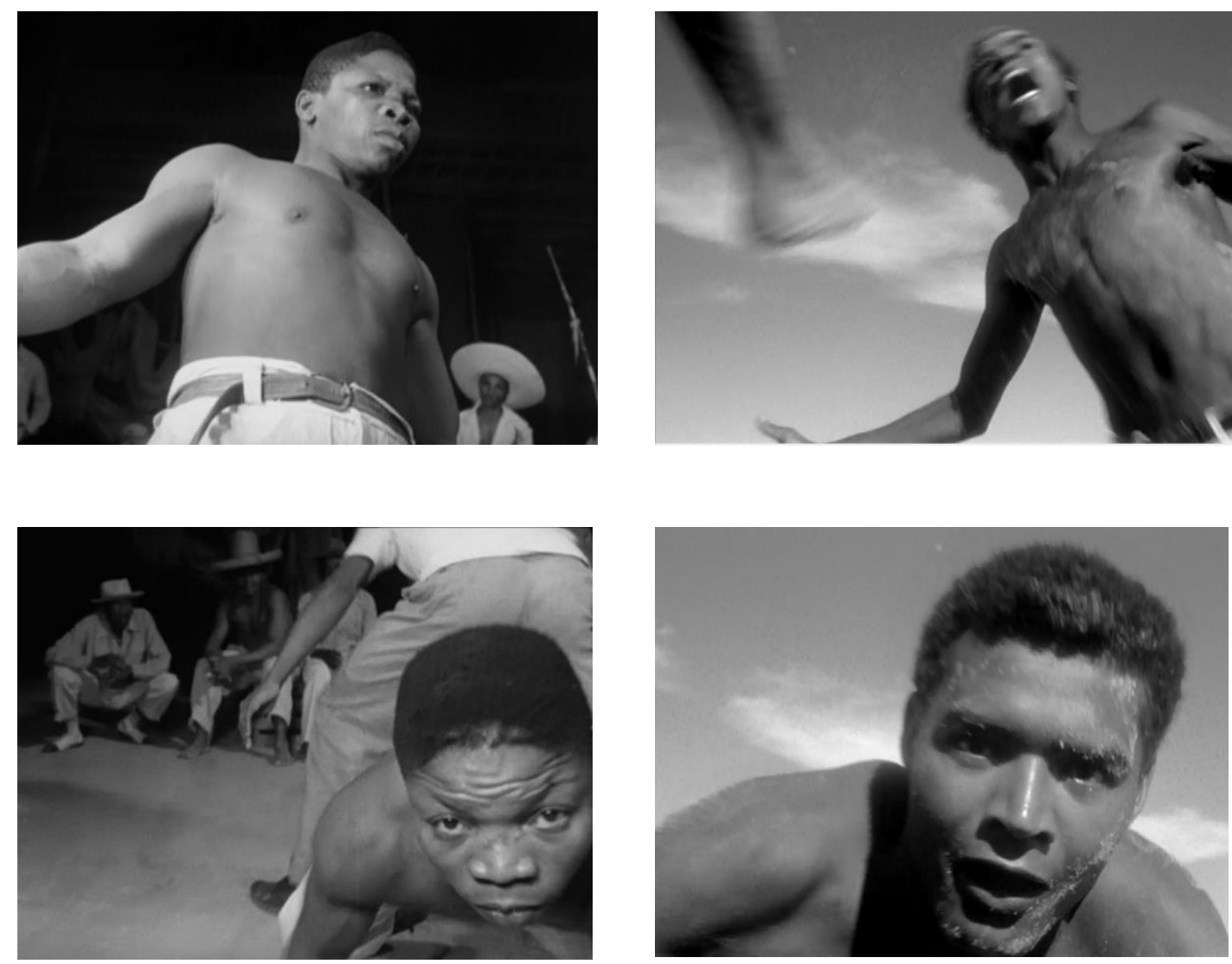

A capoeira tem duas funções em Barravento. No começo do filme, após a chegada de Firmino, ela está incluída dentro do que Ismail Xavier define como um "retrato da aldeia, povo e paisagem, trabalho e costumes". 52 Nesse sentido, seria um elemento acessório que compõe e dá verossimilhança à representação cultural do microcosmo da comunidade. Contudo, ela já explicita tensões entre Firmino e Aruan: na sequência do samba, o malandro tenta trazer Naína para a roda, ela resiste e Aruan sai em sua defesa, começa uma confusão e a harmonia festiva da roda de samba se transforma em jogo de capoeira entre Firmino e Canjiquinha. Isso nos conduz à sua segunda função: a capoeira objetiva o clímax da tensão entre forças contrárias, e sua convergência.

E é então, no último confronto entre Aruan e Firmino, que ela aparece em todo o seu potencial performativo. Como podemos verificar nos fotogramas acima, a força cênica que se anunciava em Vadiação é retomada. Nessa sequência há uma síntese dramática dos diferentes momentos coreográficos da câmera de Robatto: planos médios registrando a interação entre os dois oponentes, americanos para movimentos individuais ou de luta cerrada, e planos fechados, mais subjetivos, sobre o rosto das personagens.

$52 \quad$ XAVIER, op. cit. p.30. 
A relevância da sequência se reflete no nível de detalhamento previsto desde o roteiro original: seria a terceira maior do filme, com nada menos que 34 planos (626-660), depois do samba de roda (60 planos) e da entrada de Naína na camarinha (51 planos). O aspecto épico da luta aparecia na descrição: “GPG Aruan já avança de tarrafa na mão e Firmino de arpão em riste, como dois guerreiros africanos." ${ }^{53}$ Como a conhecemos, a sequência realizada por Glauber tem 20 planos em cerca de um minuto, o que dá conta de uma coreografia acelerada, uma rápida combustão entre os contrários.

No conjunto do enredo, a luta final de capoeira é a elevação da categoria dos corpos ao ápice da sua potência a partir de uma ideia política, isto é, a materialização da força revolucionária do corpo negro idealizada por Glauber Rocha, o que representa, no nível simbólico, a vitória dos princípios seculares do homem urbano sobre a ingenuidade do homem da província.

Assim, mais uma vez, Glauber mobiliza um repertório imagético de aspecto documental dando-lhe uma carga simbólica e histórica. Barravento aproveita a vocação cênica e performativa que Vadiação revela na capoeira com o objetivo de expor um tipo de corporeidade revolucionária. Não se pode dizer que esse entendimento da performance abandone de todo a contemplação erótico-poética que reverbera de Robatto Filho a Jorge Amado, mas ela perpassa também um novo sentido: o corpo negro como símbolo e protagonista, dentro da cultura brasileira, de resistência e adaptabilidade à violência do processo de metropolização, e de uma superação possível das mazelas econômicas de origem colonial.

$53 \quad$ ROCHA, op. cit., p.104. 


\section{Capítulo 2. Análise das personagens de Barravento}

\subsection{Mestre, os trâmites da autoridade}

Dentro da comunidade de pescadores de Barravento, a personagem a quem é dado gerir os diferentes lados das relações de poder no campo social e econômico, persistindo nos valores da tradição, é o Mestre (Lídio Silva), cujo nome indica, antes de mais nada, a posição hierárquica que ocupa na ordem social da aldeia. Os documentários de pesca dirigidos por Robatto Filho nos anos 1950 (Entre o mar e o tendal e Xaréu) assim como a importante reportagem de Odorico Tavares publicada n'O Cruzeiro em 1947 (“A pesca do xaréu”) fornecem informações importantes sobre o que seja um "mestre" dentro do universo pesqueiro tradicional do litoral baiano.

Trata-se do "mestre das redes". De modo geral, é um indivíduo que, pela experiência e domínio técnico acumulados, alça a uma posição de coordenação das diferentes dimensões da pesca dentro da comunidade praieira: o preparo das redes, indicação de eventuais reparos da linha, o trato com o intermediário econômico que receberá a maior fatia do produto e a coordenação do arrastão propriamente dito. Tamanha é a sua preponderância que em raras ocasiões entra no mar com os demais pescadores, isso porque lhe cabe fornecer as diretrizes a partir da praia, com um apito no qual estariam enroladas uma fita azul e uma branca, cores representativas de Iemanjá.

Odorico Tavares chega a mencionar dois "mestres", um do mar e outro da terra, trabalhando em estreita coordenação. Segundo a reportagem, o primeiro é um mergulhador exímio e sensitivo, pois o seu trabalho se baseia em sondagem e intuição. Ele vai à frente de todos os pescadores e mergulha na zona de pesca para adiantar o prognóstico do cardume, que codifica para o mestre da terra com sinais de som e movimentos do chapéu. Importantíssimo, portanto, ele está ligado à economia e despensa da força de trabalho. O segundo, por sua vez, interpreta os sinais e reúne os homens a postos na praia para o início do trabalho coletivo, com seu respectivo apito. Não temos notícia em Barravento dessa dupla, que parece sintetizada, mesmo nos quadros de pesca, na personagem interpretada por Lídio Silva.

Outro detalhe da maior relevância é que o Mestre está incumbido da repartição do produto da pesca dentro de uma estratificação social muito rigorosa, em cujo topo está o dono das redes, seguido pelo próprio mestre, os pescadores mais experientes e assim 
por diante, até o chamado "lava-pés": o que há de menos importante no produto da pesca. Esse subproduto são os pequenos peixes sem valor comercial que ficam presos na rede, oferecidos em geral às mulheres. Isso significa que o papel desse indivíduo, e aqui já entramos nas relações diegéticas de Barravento, estará intimamente ligado a tramitações de poder em uma zona de fronteira simbólica: entre a chefia dentro da comunidade, que ele assume sobretudo pela coordenação do trabalho, e o poder econômico externo, personificado pelo proprietário dos meios de produção, o dono das redes. Em complemento às competências práticas, não se pode deixar de lado uma certa dimensão mística da sua liderança.

Tanto as reportagens d'O Cruzeiro quanto os documentários de Robatto Filho nos permitem observar que, para as comunidades tradicionais de pesca dos arredores de Itapoã, ainda nos anos de 1950, o trabalho era indissociável de um ritmo ritualístico e de uma conotação espiritual, e a prova é que, durante o arrastão, os pescadores cantam, entre toadas de trabalho, pontos de Orixás, as cantigas consagradas às divindades maiores da mitologia iorubá. O primeiro ponto que se escuta na sequência de pesca em Barravento é o de Nanã Buruku, que se conhece atualmente pela variante a seguir:

$$
\begin{aligned}
& \text { Nanã ke um já sitó, Alodê } \\
& \text { Nanã ke um já sitó, Alodê } \\
& \text { Nanã ke um já ossí, Alodê } \\
& \text { Nanã ke um já ossí, Alodê }
\end{aligned}
$$

Nanã, dentro do panteão do candomblé, é uma divindade anciã que encarna a ancestralidade por pertencer a uma primeira geração de Orixás. O metal não participa do

\footnotetext{
54 É possível encontrar as mais diversas ortografias desse ponto devido à ausência de convenção na transliteração da língua iorubá para o português. Procuramos nos aproximar daquela proposta por GASPAR, Eneida (org.). Cantigas de umbanda e de candomblé: pontos cantados e riscados de orixás, caboclos, pretos-velhos e outras entidades. Rio de Janeiro: Pallas Editora, 2008. No que diz respeito ao seu significado, é Roger Bastide quem trata da impossibilidade de se traduzir alguns dos pontos devido ao nível de erosão da língua original. Segundo o autor, muitos dos praticantes da religião sendo à época iletrados, os pontos foram durante muito tempo difundidos oralmente, sem registros escritos que lhes fixassem a forma: BASTIDE, Roger. O candomblé da Bahia - rito Nagô. Trad. Maria Isaura Pereira de Queiroz. São Paulo: Companhia Editorial Nacional, 1961.
} 
seu culto, ${ }^{55}$ um dos elementos da natureza que lhe são atribuídos é a lama, o lodo, representando neste caso tanto o elemento físico da zona de transição entre o mar e a terra, quanto um signo de providência - a lama de Nanã no contexto da pesca é símbolo de fertilidade e prosperidade. ${ }^{56} \mathrm{~A}$ ausência do metal indica ainda o passado remoto do seu culto, de uma época anterior à manufatura do ferro, portanto mais ligado a formas de trabalho antiquíssimas como a pesca. Ademais, na umbanda, "Nanã é uma cabocla da Linha de Iemanjá"57 e comandante das Ondinas, o que sublinha seu vínculo com o universo marinho e praieiro do filme.

A evocação desse repertório espiritual no processo do trabalho explicita a conexão do mundo místico com o mundo laboral e, no caso da personagem em questão, que o Mestre, ao transitar por essas duas zonas, é também um indivíduo de envergadura religiosa, embora não participe diretamente da organização ritualística do barracão/terreiro e não figure nos quadros hierárquicos da casa. Em Barravento, o Mestre está para o espaço externo assim como Mãe Dadá está para o espaço interno. Raras as cenas em que essas figuras trocam de posição. Assim como os interiores do filme estão quase que na sua totalidade ligados aos rituais candomblezeiros, o Mestre é visto praticamente em todas as suas cenas nos ambientes externos (à exceção das exéquias de Chico). A título de exemplo, o balanço entre o poder exercido por esses dois indivíduos aparece em uma fala de Aruan que não foi incluída no filme, mas que se encontra nas folhas avulsas do script datilografado:

[...] Firmino é independente, faz o que quer e tem

Cota na hora que bem entende....

João: Tem sede nela?Por que não pega?

Aruan: pra Mãe Dadá, o Mestre dá tudo em cima de mim?Não aguento mais

não...Um homem como eu...

\footnotetext{
55 A lenda diz que Ogum, Orixá mais jovem ligado ao metal, teria ferido Nanã Buruku, razão pela qual o metal é banido de sua liturgia. PRANDI, Reginaldo. Mitologia dos Orixás. São Paulo: Companhia das Letras, 2001.

56 GATTI, José. Barravento: a estreia de Glauber. Florianópolis: Ed. da UFSC, 1987.

$57 \quad$ GASPAR, op. cit. p.57.
} 
A passagem acima está na página 17 do script, encabeçada pelo título em caixa alta "PARA ARUAN E JOÃO", e foi inteiramente rasurada, talvez por apresentar um Aruan mais confessadamente carnal do que conviria antes do climático desvirginamento. Por outro lado, a fala demonstra como, dentro do vilarejo, mesmo uma personagem central e carismática como Aruan é castrada na expressão de sua pulsão sexual pelas duas esferas do poder tradicional: a do barracão e a do tendal, de dentro e de fora. Na lógica dos valores comunitários do filme, o indivíduo enquanto um todo movido a impulsos íntimos e subjetividade é soterrado pelas necessidades coletivas, que são o equilíbrio e a comunhão entre a natureza física do trabalho e o mundo espiritual. A figura do Mestre traduz esse sentido ordenador entre as duas esferas.

A câmera também vem em mais de um momento reforçar simbolicamente a preponderância do chefe da pesca. Diversos excertos do roteiro original apresentam passagens onde as intervenções do Mestre estão associadas à abreviação PP, "primeiro plano", a que Glauber aderiu na filmagem. Alguns exemplos abaixo:

p.5

\begin{tabular}{|l|l}
\hline $45-$ & Mestre em PP.Pernas dos pescadores
\end{tabular} batendo na areia da praia

Vozes,ruídos,eip...eip...eip...

p.31

\begin{tabular}{|l|l|l|}
\hline 304- & Mestre fala em PP & $\begin{array}{l}\text { Mestre:Tá tudo muito bonito, } \\
\text { mas valentia num resolve. } \\
\text { Conheço as coisas de per- } \\
\text { to, sei o que é passá fo } \\
\text { me e ter de pescar em } \\
\text { mar brabo.O geito é com- } \\
\text { sertá a rede todo mundo } \\
\text { de vez. }\end{array}$ \\
\hline
\end{tabular}

p.37

\begin{tabular}{|l|l|l|}
\hline $357-$ & Mestre em PP & $\begin{array}{l}\text { Mestre:Nada disso adianta } \\
\text { Podem levaa rede de- } \\
\text { lesque depois nós ta- } \\
\text { mo livre... }\end{array}$ \\
\hline
\end{tabular}


Observe-se, no plano 45, como a configuração hierárquica se transforma simbolicamente nas projeções do corpo. A relação Mestre - pescadores é metonimicamente traduzida pelo contraste entre um primeiro plano (cabeça) e "as pernas", refletindo respectivamente o pensamento diretivo e a ação coletiva. O Mestre está em foco na qualidade de mentor, o conjunto dos pescadores como corpos executores. $\mathrm{Na}$ descrição dos dois planos seguintes, as falas do Mestre oscilam entre o encorajardesencorajar, isto é, encorajar o trabalho como única via de confrontar a miséria material, desencorajar a insubordinação e revolta contra o poder externo. É um estica e puxa na ordem comunitária que se assemelha ao próprio puxar da rede, a rede simbólica sendo nesse caso uma noção de respeito e temor às esferas da ordem - o coletivo tradicional e o mundo externo que impõe as leis econômicas.

Por sua relação fronteiriça com duas ordens de poder e seu modo de ação, a análise da personagem ganha nuances com o aporte teórico de Frantz Fanon. O trabalho do psicanalista martiniquense entrará no horizonte teórico de Glauber Rocha em meio ao crescendo ideológico que se dá com a tomada de consciência das mazelas oriundas do passado colonial e da precariedade material do cinema brasileiro. Essa percepção intelectual de Glauber dá os primeiros sinais com o importante testemunho da "Experiência Barravento: confissão sem moldura", e culmina no manifesto nitidamente fanoniano de 1965, "Uma estética da fome". ${ }^{58}$ Segundo o próprio Glauber Rocha, ${ }^{59}$ à altura de Barravento ainda não tinha sido apresentado ao trabalho do teórico, mas fica claro que a convergência das ideias sobre relação colonial e subdesenvolvimento já estava conduzindo ao inevitável encontro.

O colonizado consegue igualmente, por meio da religião, não ter em conta o colono. Através do fatalismo, toda a iniciativa é arrebatada ao opressor, atribuindo-se a Deus a causa dos males, da miséria, do destino. Dessa maneira o indivíduo aceita a dissolução decidida por

58 Arlindo Rebechi Junior propõe uma espécie de um crescendo crítico-teórico que vai do artigo "Experiência Barravento: confissão sem moldura" (1962) a "Luz Atlântica" (1962) e culmina com “Uma estética da fome” (1965). "Glauber Rocha e a crítica de cinema no Diário de Notícias: periferia e resistência." in Contemporânea: Revista de Comunicação e Cultura, Brasil, v.11, n.03, p.522-534, dez. 2013.

59 ROCHA, Glauber. "Arnaldo Carrilho" in Revolução do Cinema Novo. São Paulo, Cosac \& Naify, 2004. p.455-457. 
Deus, avilta-se diante do colono e diante da sorte e, por uma espécie de reequilíbrio interior, chega a uma serenidade de pedra. ${ }^{60}$

O trecho acima foi extraído de Os condenados da Terra, obra oriunda do estudo dos efeitos psicológicos sobre os indivíduos no contexto das ordens institucionais agonizantes do sistema colonial. Aqui, Fanon ataca frontalmente o sistema religioso em sua ação paralisante e conformadora. Observe-se como a associação entre misticismo e fatalismo se assemelha aos pressupostos do letreiro inicial de Barravento:

Permanecem até hoje os cultos aos Deuses africanos e todo este povo é dominado por um misticismo trágico e fatalista. Aceitam a miséria, o analfabetismo e a exploração com a passividade característica daqueles que esperam o reino divino.

Para além disso, Fanon nos permite vislumbrar um certo perfil psicológico dentro da ordem colonial e, por conseguinte, uma ética da inação que caracteriza a atitude de alguns indivíduos diante das ordens tradicionais, uma vez que estariam sujeitos à alienação religiosa. É uma ética análoga à do Mestre diante dos eventos perpetrados, direta ou indiretamente, por Firmino em Barravento. Muito dessa ética vai se explicitar pela tonalidade dos seus discursos.

Os três âmbitos em que se manifestam suas intervenções orais revelam os fundamentos de sua autoridade:

a) Ele é um portador da memória coletiva, o que se verifica quando evoca histórias do passado do vilarejo.

b) Ele profere verdadeiros vereditos, isto é, tomadas de decisão sobre os rumos da coletividade tanto na atividade econômica quanto no plano do juízo moral, guiado pelo preceito religioso e desviando a atenção coletiva da origem econômica da opressão.

c) Ele é o único personagem que tem representatividade direta e reconhecida pelas autoridades do mundo externo ao vilarejo, aquelas que incorporam a grande ordem econômica que efetiva a exploração e o aprofundamento da 
pobreza local. Nesse espaço, o seu discurso assume uma expressão muito mais submissa.

Com relação ao ponto a) cabe dizer que o Mestre se inscreve em uma linhagem de personagens praieiros, os anciãos do mar. Figuras carismáticas e respeitadas em suas comunidades, eles detêm um saber coletivo misturando mito e memória. Um exemplo bastante correlato na Literatura é o velho Francisco do romance Mar morto (1936), de Jorge Amado:

O velho Francisco conhece essa música e esse mundão de estrelas que se reflete no mar. Senão, de que valeriam quarenta anos passados em cima de um saveiro! E não é só as estrelas que ele conhece. Conhece também todas as coroas, as curvas, os canais da baía e do rio Paraguaçu, todos os portos daquelas bandas, todas as músicas que por ali são cantadas. Os moradores daquele pedaço de rio e do cais são seus amigos, e há até quem diga que uma vez, na noite, em que salvou toda a tripulação de um barco de pesca, viu o vulto de Iemanjá, que se mostrou a ele como prêmio. Quando se fala nisso (e todo jovem mestre de saveiro pergunta ao velho Francisco se é verdade), ele somente sorri e diz:

- Se fala muita coisa neste mundo, menino... Assim, ninguém sabe se é verdade ou não.

Bem que poderia ser. Iemanjá tem caprichos e se havia alguém que merecesse vê-la e amá-la era o velho Francisco, que estava na beira do cais desde ninguém sabe quando. Ainda melhor, porém, que todas as coroas, os viajantes, os canais, ele conhece as histórias daquelas águas, daquelas festas de Janaína, daqueles naufrágios e temporais. Haverá história que o velho Francisco não conheça? ${ }^{61}$

O velho Francisco, assim como o Mestre, detém essa espécie de grande mapeamento da vida comum do homem do mar, que perpassa o conhecimento do ofício, da paisagem e da relação com a natureza, a atenção aos preceitos religiosos e, por fim, concatena a materialidade do cotidiano com a intangibilidade do mito. $\mathrm{O}$ velho Francisco

61 AMADO, Jorge. Mar morto. Rio de Janeiro: Record, 63ª ed., 1990, p.16. 
evoca as tempestades do passado como o Mestre evoca o barravento de outros tempos. Na qualidade de sobreviventes, seu poder se substancializa no seio de suas comunidades.

Há que se fazer certas ressalvas a essa comparação, contudo. O velho Francisco é um homem da cidade e o Mestre, um itapuãzeiro, o que lhes dá horizontes de mobilidade e convívio social bastante distintos. O velho Francisco é um saveirista, e por isso exerce sua força de trabalho sobre si mesmo. Ele carrega, como proprietário, seu meio de produção, ainda que sua condição material não lhe garanta nenhuma ascensão econômica na estrutura social. O seu modo de trabalho se baseia em grandes deslocamentos e na comunicação entre espaços diversos. O mestre não apenas não detém o seu meio de produção, como exerce um micropoder sobre os indivíduos de sua comunidade de modo a coordenar o trabalho coletivo. Essa distinção fundamental faz com que a concentração de poder sobre o Mestre o torne muito mais inflexível e autoritário na economia do enredo, muito menos simpático que o velho Francisco.

Mas a materialização do poder do Mestre se dá também pelo regime da sua performance corporal e da gestão dos corpos que procura exercer. Isto é, combinadas àqueles "primeiros planos" de que falamos mais acima, as aparições do Mestre são extremamente estáticas, em exata oposição ao dinamismo exacerbado de Firmino, uma personagem convulsiva e irrequieta. É a própria tradução gestual da "serenidade de pedra" de que Fanon nos fala. Não apenas isso, a personagem procura impor a imobilidade aos demais. Veja-se a fala a seguir:

- Ninguém se mexe, a lei tá com eles.

- Nós temos que reagir. Viemo de lá escravo mas a escravidão já acabou.

- Direito de pobre é trabalho. [...] Tem de ser assim até o fim.

O que seria esse "fim" ao qual a personagem se refere? Seria talvez a possibilidade de uma extinção coletiva que revela a consciência do caráter decadente da economia local. O Mestre poderia estar se referindo ainda ao fim individual, à morte. Em todo caso, é um "fim" que se liga à ideia de fatum, logo "destino", logo "fatalismo", evocando mais uma vez o conceito fanoniano de alienação religiosa que contamina as esferas das relações sociais e econômicas. E vai ainda mais longe, porque essa gestão dos corpos encontra sua forma limite na própria transigência sobre a morte. O Mestre atribui ou retira o valor dos indivíduos inclusive inanimados. Estamos nos referindo aqui a uma 
outra dimensão de seus "vereditos", aquela que enunciamos no ponto b). Analisemos um exemplo.

Quando a ação de Firmino se encerra, enfim, e Aruan é derrotado, o malandro profere seu último discurso, legando ao jovem caído a condução do povo. O discurso ecoa no vácuo. Firmino se afasta. A câmera não expõe nenhum tipo de reverberação coletiva, senão um primeiro plano enfático sobre o Mestre, com uma ligeira contre-plongée que acentua sua autoridade:

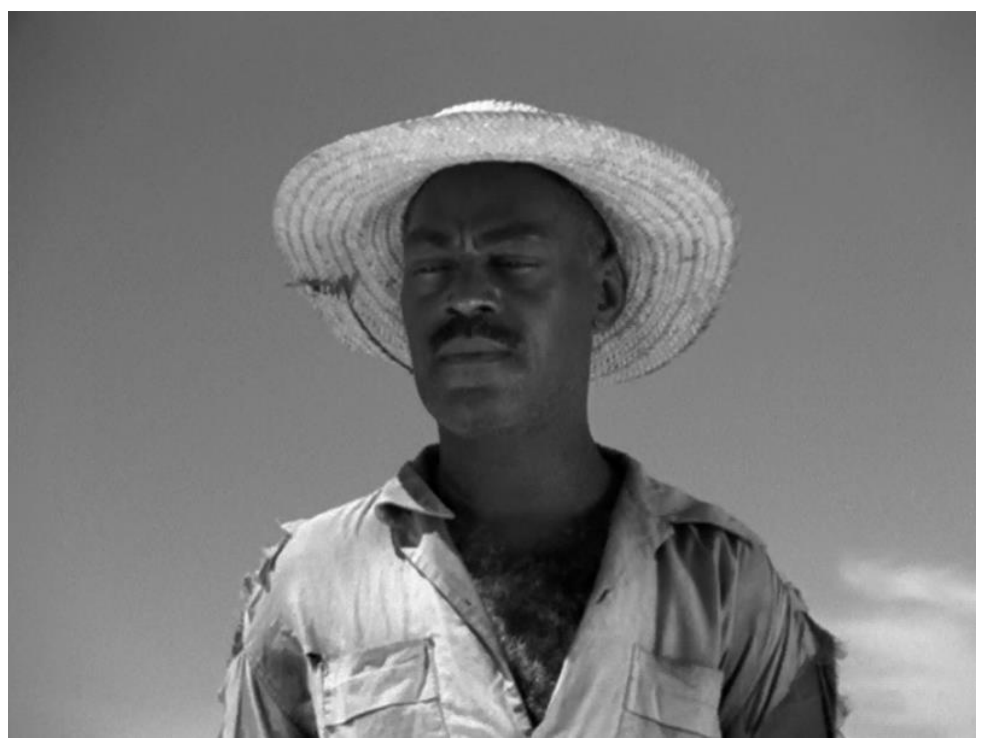

Mestre: Aruan não vale mais nada. Ninguém encosta nele. Leve o corpo!

No momento em que o Mestre profere essa fala, há dois corpos na praia, um deles, morto simbolicamente, o outro, literalmente. É o momento máximo da jurisdição do Mestre. Uma vez que já não participa da esfera do sagrado que rege a vida comunitária, Aruan é não apenas descartável, mas proscrito. E Chico, pelas mesmas leis do sagrado, deve ser reintegrado ao equilíbrio cósmico, sacralizado pelas exéquias, o axexé. ${ }^{62}$ Fica mais nítido pela análise do roteiro original que o reclame do corpo de Chico participa ativamente na estabilização da relação com o sagrado, junto com o lançamento dos cabelos de Naína no mar. Seus restos mortais são oferecidos a Iemanjá em troca da subtração do virgem Aruan.

A autoridade do Mestre sobre os corpos não recorre, contudo, à violência física propriamente dita, mas a ética da inação cria nele um papel de mediador nas tensões. E

62 BASTIDE, Roger. O candomblé da Bahia - rito Nagô. Trad. Maria Isaura Pereira de Queiroz. São Paulo: Companhia Editorial Nacional, 1961. 
nessa qualidade, sempre em detrimento dos oprimidos, sua ação é, em mais de um momento, física. Chegamos então ao ponto c), de que falamos mais acima, segundo o qual o discurso do Mestre é o único legitimado perante aqueles que exploram os pescadores. A câmera, em alguns momentos decisivos, procura captar esse balanço de forças:

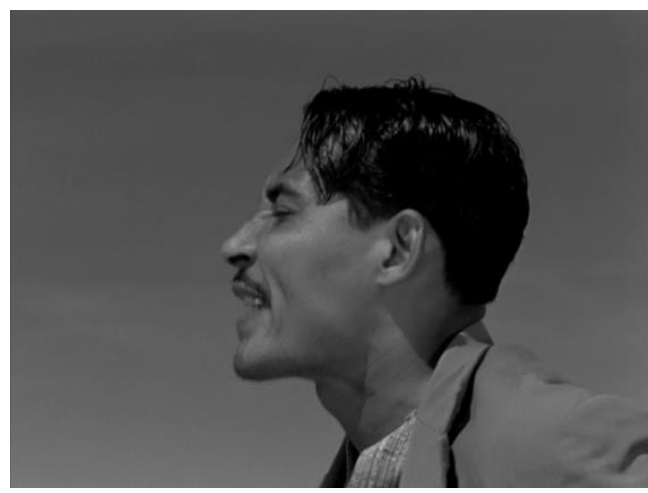

1 - "Pois é Mestre, o homem mandou dizer que quer o peixe de qualquer jeito. A rede é que não pode ficar parada. O pessoal está querendo muito e tem gente lá embaixo que paga muito mais barato."

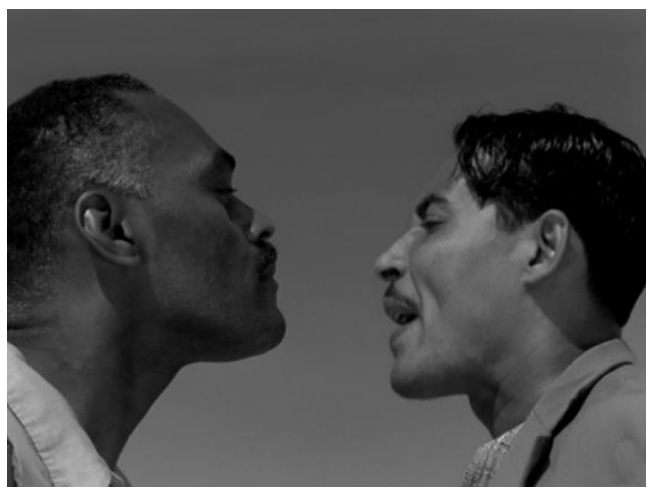

3 - "Isso não interessa, desculpa o senhor vai dar pessoalmente. O homem só quer saber do peixe e mais nada, nada."

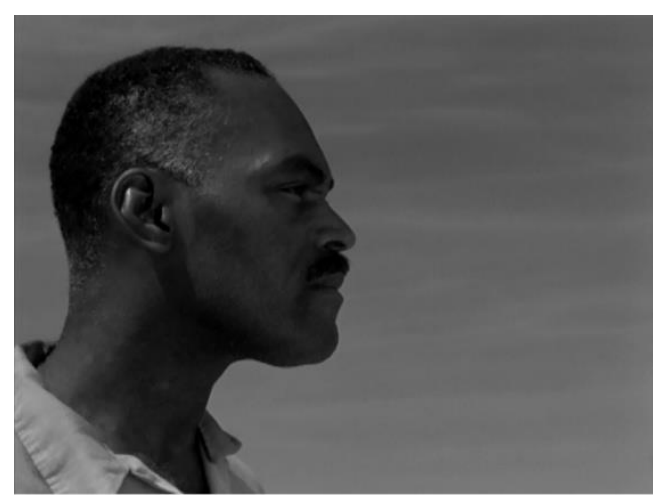

2 - "Mas o homem sabe que a rede está velha."

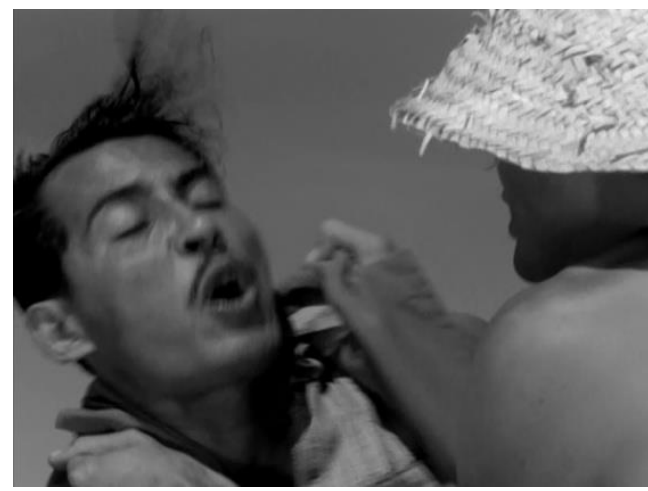

4 - "Como é que não sabe? Tem dez anos que a gente empurra essa rede e nunca precisamos de nada. Agora que dá azar ele vem com desaforo? Ninguém aqui é cachorro não." 


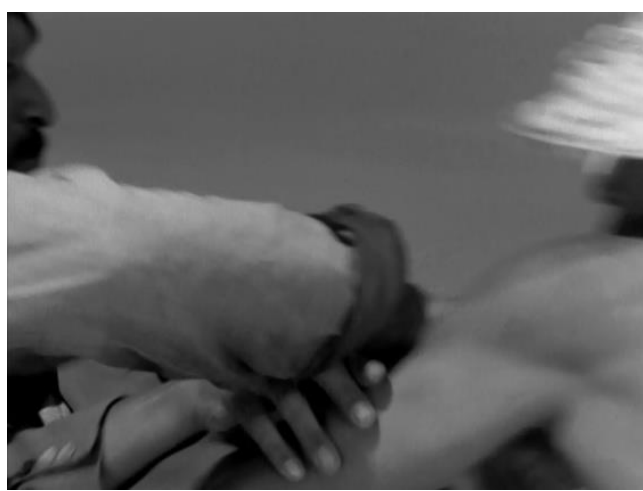

5 - O Mestre aparta Aruan.

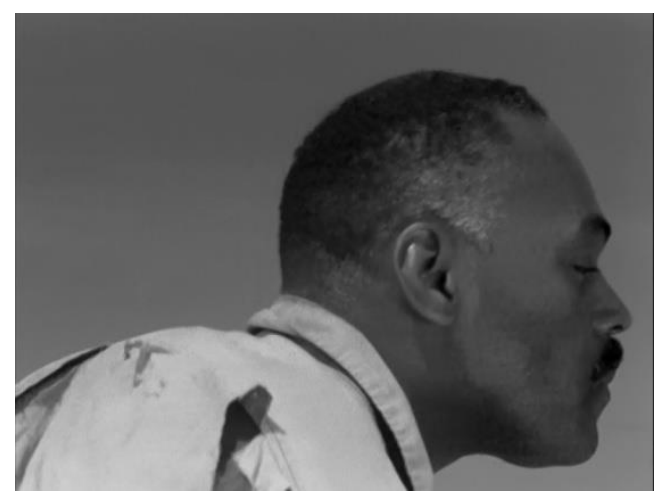

6 - "Deixa isso pra lá."

Os fotogramas acima na verdade representam um mesmo plano, não há cortes. Ao constituir um breve continuum da filmagem, a câmera procura isolar a tríade Mestremandatário-Aruan em um intuito de alegorizar uma espécie de coreografia da dinâmica dos poderes. À esquerda, o chefe local figura como um homem negro altivo apesar de sua condição material que se evidencia pela camisa rasgada; à direita, um homem mestiço cuidadosamente barbeado, cuja roupa limpa mas mal ajambrada sugere afetação. De fato, ele alegoriza o pequeno poder do executor de ordens - após ser sacudido por Aruan, seu primeiro gesto é, desconcertado, realinhar cuidadosamente os cabelos lisos devidamente lustrosos. Elemento estranho a essa dicotomia, Aruan vem do contra-campo e invade o plano com violência, chapéu de palha e torso nu. Quando a tensão se resolve em favor do mandatário ele tira o chapéu em sinal de resignação e melancolia.

O aparente equilíbrio proporcional do posicionamento de câmera é, na verdade, desmentido quando o movimento coloca em choque uma e outra representação de poder: o Mestre e o mandatário. O segundo procura sobrepujar o líder local pelo volume do discurso e o crescendo de ameaça. Há uma contradição entre a expressão altiva do Mestre e o seu silêncio em face do lacaio prolixo. No fim das contas, o verdadeiro gesto de força do velho é dirigido contra Aruan, que defende o interesse coletivo dos pescadores. $\mathrm{O}$ vaivém da câmera acompanha os três momentos da violência: Mestre versus mandatário, Aruan versus mandatário, Mestre versus Aruan.

A ambiguidade do Mestre se desvela: embora a primeira camada de sua liderança esteja intrinsecamente ligada à experiência social compartilhada da comunidade de pescadores, em meio à crise que se instala, a sua autoridade se materializa física e discursivamente a serviço da manutenção do poder externo.

O jogo de contenção dos corpos se manifesta nesses curtos lampejos de força física como um reflexo local da violência externa. Mais adiante, a tensão volta a se acirrar 
no momento da recolha das redes. Quando a zona limite é colocada novamente em risco o Mestre dá um tapa no rosto de Firmino ("Suma-se daqui, se seu pai não tivesse sido um homem decente você tinha morrido"). É aliás uma passagem em que a conceituação fanoniana do mundo colonizado vem à tona.

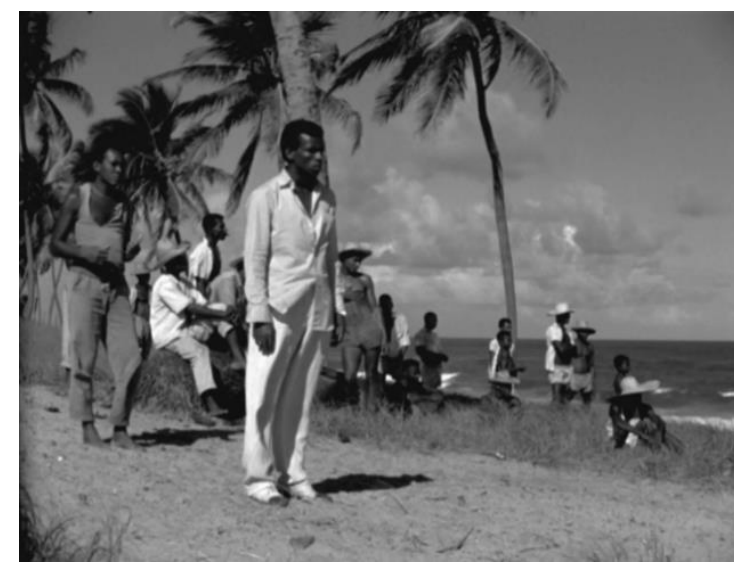

1 - Esquerda da praia

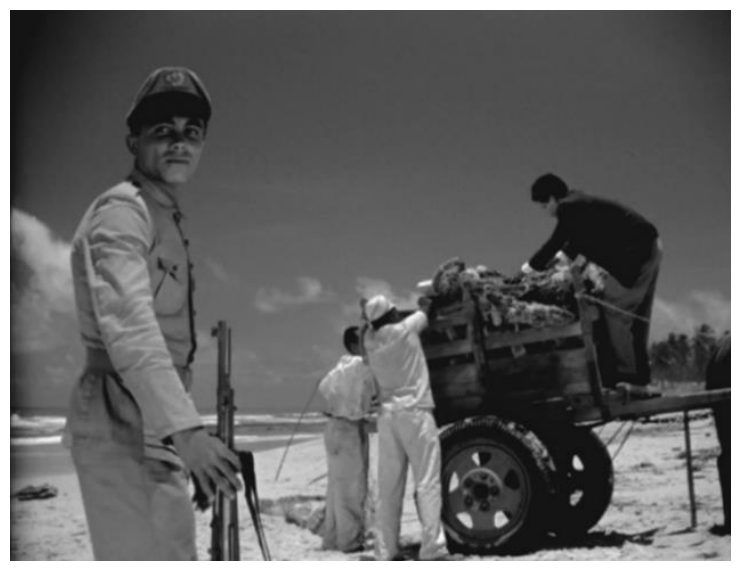

2 - Direita da praia

$\mathrm{Na}$ cena da recolha das redes a praia é dividida em dois campos. À esquerda os pescadores assistem impassíveis a execução de uma sentença definitiva sobre o seu modo de trabalho. Sem a rede, terão de pescar à moda antiga, enfrentando o mar em jangadas. À direita, volta o mandatário com a carroça e homens a seu serviço para coletar a rede; em plano americano, vê-se um soldado intimidador. Firmino vem do fundo para a frente para açular seus conterrâneos à resistência. O Mestre, evidentemente, procura neutralizálo. A efervescência chama a atenção dos carroceiros, e o soldado profere: "O primeiro que passar pra esse lado eu passo fogo.” Em toda a sequência, o conflito está ligado à manutenção da zona de limite.

O mundo colonizado é um mundo cindido em dois. A linha divisória, a fronteira, é indicada pelos quartéis e delegacias de polícia. Nas colônias o interlocutor legal e institucional do colonizado, o porta-voz do colono e do regime de opressão é o gendarme ou o soldado. ${ }^{63}$

Assim, a construção dos dois campos na praia cria um inusitado espelhamento entre a contenção do Mestre, de um lado, e a contenção dos mandatários do outro. Em 
outras palavras, o Mestre em sua função constringente está alinhado ao soldado e ao mandatário. É assim que o poder crepuscular da província, representado pelo velho chefe local, passa a refratar a coerção das forças de repressão urbanas (econômicas, sociais, policiais) que estão em franca expansão à época de Barravento. Procuraremos demonstrar esse fato com mais detalhe na análise seguinte.

Para colocar em perspectiva a paralisia do Mestre e sua ética da inação, é preciso uma violência de natureza contrária, descompressora. Fanon dirá que o inconsciente do indivíduo colonizado exprime uma vontade recalcada de movimento e ruptura da autocracia do sistema colonial: "A primeira coisa que o indígena aprende é a fícar no seu lugar, não ultrapassar os limites. Por isso é que os sonhos do indígena são sonhos musculares, sonhos de ação, sonhos agressivos." ${ }^{64}$ Firmino não é propriamente o "indígena" idealizado nos termos de Fanon, sua experiência já traz um acumulado de violências urbanas e provincianas históricas, por isso ele é a materialização candente desse desejo de mobilidade, tanto no plano social quando espacial. É ele que passamos a analisar.

\subsection{Firmino, um malandro brechtiano.}

Firmino: Quem é vivo sempre aparece, e Firmino Bispo dos Santos filho dessa terra bonita não vai esquecer os velhos amigos. Vem sempre matar a saudade, é ou não é, João?

Aruan: Deixa esse cara pra lá, pessoal. Firmino tá com a vida dele ganha. Não tá vendo pela roupa?

Firmino: É o que você pensa, velho. Esse gosto de riqueza eu não posso dar pra mim. Mas de pobreza eu não dou pra ninguém. O papai aqui pra jogar esses panos em cima dele teve que descarregar muito navio escondido da polícia. [...] Firmino velho teve de dar duro até que a polícia baixou na sua sombra. Vim me esconder de polícia que ela só gosta de sol.

No conjunto das personagens de Barravento, Firmino (Antonio Pitanga, então Sampaio) é a única cujo nome e sobrenome são conhecidos, e anunciados por ele mesmo, aliás, desde a sua primeiríssima fala, transcrita acima. Uma hipótese inicial levaria a crer

$64 \quad$ FANON, op. cit., p.39. 
que a reiteração desse nome completo é uma ênfase na individualidade que o distingue da massa coletiva e coordenada de seus antigos amigos pescadores. Ele não é só-João, sóChico, só-Aruan. É um cidadão de prenome e nome, com documento.

Essa particularidade o imbui de uma carga mais concreta e material, oposta à das outras personagens, que estão, ao menos a princípio, imersas no sistema de valores tradicionais da comunidade com seus simbolismos e alusões espirituais. Estamos falando de Aruan (Aldo Teixeira), cujo nome é a contração de Aruanda, o paraíso da mitologia iorubá e umbandística, e de Naína (Lucy Carvalho), cujo nome se refere a Janaína, uma das denominações de Iemanjá.

É claro que "Bispo dos Santos" é um nome carregado de sentido transcendente e religioso, inclusive porque prenuncia o esforço messiânico de liderança e "pregação" que marcam a atuação de Firmino dentro da trama, no entanto, ecoa com força um estatuto urbano e comum, de homem do povo, um integrante das massas. Assim, temos uma contradição de base: se é o nome-sobrenome que individualizam o malandro dentro do vilarejo de Buraquinho, o caráter comum dessa identidade o dilui dentro de uma ordem externa, dos muitos Silvas e Santos urbanos e pobres, da massa anônima e marginalizada da capital, em grande parte migrantes.

A ambiguidade do nome conta por si só uma história: Firmino, pescador, viveu o êxodo para a metrópole em busca de oportunidades, para se tornar cidadão, vestiu-se de homem urbano, moderno e adaptável, mas resvalou na marginalidade pela escassez de emprego e a urgência de subsistir na capital. De volta à terra natal, ele é um arauto de novas ideias, políticas, um espírito revolucionário.

O enredo de Barravento nos propõe um experimento teatral: encenar o antiêxodo do ex-pescador, e a irrupção de uma individualidade moderna e politizada, desestabilizando um sistema hermético de valores tradicionais "arcaizantes". No entanto, a evolução da trama apenas aprofunda a marginalidade de Firmino nas duas esferas, cidade e província. A sua militância é solitária. Hostilizado e hostil com seus conterrâneos, ele proclama a ação coletiva para a revolta, mas as consequências de seus atos produzem menos a revolução coletiva do que a tomada de consciência individual de Aruan (essa fórmula será retomada por Glauber anos mais tarde, em artigo de 1967, intitulado "A revolução é uma eztetyka").

O termo "teatral" não é aqui uma casualidade. A teatralidade cinematográfica de Barravento foi mencionada por Glauber Rocha anos mais tarde: "Do filme Di Cavalcanti 
para cá eu rompi com o cinema teatral que fiz de Barravento até Claro"65 - e tem raízes no seu processo de formação artística. Uma das suas primeiras experiências de cunho criativo de que se tem notícia são os célebres saraus intitulados Jogralescas, que propunham performance e recitação de poesia moderna. Em retrospecto, Glauber os denominará "Teatralyzação Poetyka baiana". ${ }^{66}$ Já em 1959, sua primeira incursão no cinema como diretor, o curta-metragem Pátio, também apresentava uma forte tonalidade teatral baseada em um enredo aberto, com o jogo entre montagem de imagens e a preponderante performance corporal da atriz Helena Ignez.

$\mathrm{Na}$ entrada dos anos 1960, Glauber incorpora ao seu repertório uma nova matriz teatral. O jovem estudante universitário de Feira de Santana estava atento ao amplo quadro de renovação cultural por que passava Salvador desde meados dos anos 1950, em torno da criação da Universidade da Bahia, com seu corpo docente ligado às novas vanguardas europeias. ${ }^{67}$ Dentre eles, o professor da Escola de Arte Dramática, Eros Martim responsável por uma montagem de grande sucesso da Ópera dos três vinténs. Era a segunda montagem profissional do dramaturgo alemão no Brasil, no segundo semestre de 1960, e Glauber, que estava em Itapuã em meio às filmagens de Barravento, relata: "um dia eu fui a Salvador para assistir ao espetáculo. E aquilo realmente me transtornou, foi uma descoberta tardia, mas importantíssima." 68

Ainda na contemporaneidade de Barravento, Brecht volta a ser evocado no importante artigo "Experiência Barravento: ficção sem moldura". Esse artigo, publicado em 25-26 de dezembro de 1960, é uma espécie de balanço escrito poucas semanas após o término das filmagens, e o dramaturgo alemão figura como uma espécie de tutor teórico da atitude artística ideal: “A covardia é o grande defeito do cinema brasileiro e Bert Brecht (sic) recomenda coragem aos autores." ${ }^{69}$ Haveria talvez algo de brechtiano no próprio título do artigo, se pensarmos na ideia de experiência e ficção sem o enquadramento imersivo da forma artística.

\footnotetext{
65 ROCHA, Glauber. "Estão confundindo minha loucura com minha lucidez" in Revolução do Cinema Novo. São Paulo, Cosac \& Naify, 2004, p.497.

$66 \quad$ Ibid, p.277.

67 RISÉRIO, Antonio. Avant-garde na Bahia. São Paulo: Instituto Lina Bo e P.M. Bardi, 1995.

68 ROCHA, op. cit., p.117.

69 Id., "Experiência Barravento: confissão sem moldura". Diário de Notícias de Salvador, Salvador (BA), 25-26 dezembro 1960.
} 
Com foco na personagem central, Firmino, pretendemos demonstrar de que forma alguns elementos teóricos do drama épico brechtiano teriam sido assimilados em Barravento, em especial na relação entre enredo, montagem, trilha sonora e performance gestual. A análise contrastiva entre alguns aspectos do roteiro inicial e daquele reescrito por Glauber Rocha é reveladora. Observemos, por exemplo, a primeira e a segunda versão da entrada de Firmino:

Roteiro inicial

SEQUÊNCIA 5_Idem tempo/ praia, puxada - CONTRAPONTO

\begin{tabular}{|l|l|l|}
\hline $36-$ & $\begin{array}{l}\text { Os pescadores puxam a rêde com } \\
\text { ritmo/cânticos característicos }\end{array}$ & Cânticos de puxada \\
\hline $37-$ & $\begin{array}{l}\text { De cima de uma pedra,Farol ao } \\
\text { fundo(infinito), pula/Firmino, } \\
\text { chegando de longe.Está todo de branco } \\
\text { paletó e gravata,com enfeites na la- } \\
\text { pela, chapéu.... }\end{array}$ & Idem.... \\
\hline
\end{tabular}

Roteiro refeito

\begin{tabular}{|l|l|l|}
\hline $36-$ & $\begin{array}{l}\text { Os pescadores puxam a rêde com } \\
\text { ritmo:Canticos característicos. } \\
\text { ARUANE EAÍNA EMCAMPO }\end{array}$ & Música característica \\
\hline
\end{tabular}

SEQUENCIA 2A- EXT-DIA-PRAIA-Farol de Itapoan. (Manhã)

\begin{tabular}{|l|l|l|}
\hline 36.- & $\begin{array}{l}\text { De cima de uma pedra, fa- } \\
\text { rol ao fundo,salta Firmi- } \\
\text { no.Cai na areia da praia } \\
\text { equilibra-se,começa a an- } \\
\text { dar,gingando o corpo,co- } \\
\text { mo malandro. } \\
\begin{array}{l}\text { Está de roupa panamá } \\
\text { creme,gravata,com enfei- } \\
\text { tes na lapela.(Travelling) }\end{array}\end{array}$ \\
$\begin{array}{l}36-\Lambda=\text { FIRMINO } \\
\text { CONTINUA }\end{array}$ & $\begin{array}{l}\text { Música marcante : } \\
\text { Oia tu que émoleque } \\
\text { Moleque é tu. } \\
\text { Oia tu que é moleque }\end{array}$ \\
\hline
\end{tabular}




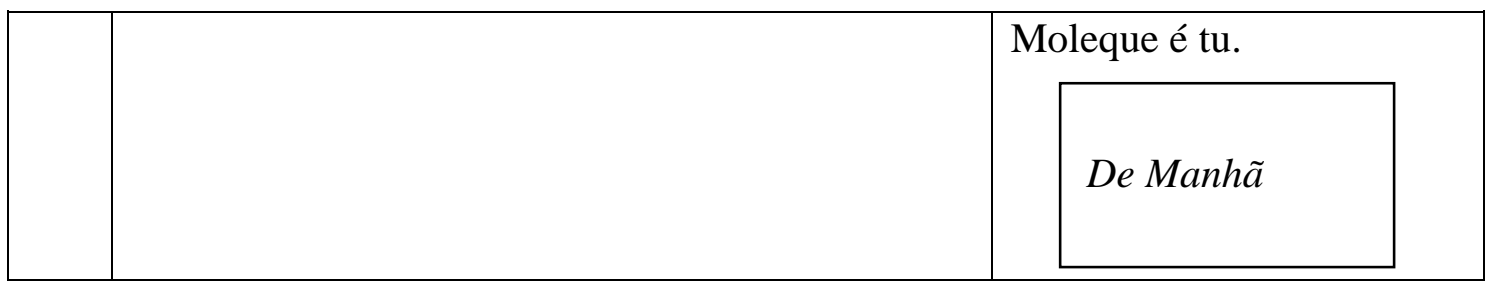

Embora a primeira versão do roteiro anuncie um "contraponto" no título da sequência, provavelmente devido à oposição entre Firmino e os pescadores, o efeito pretendido, ficando restrito ao conteúdo dos planos, é mitigado pela pouca tensão formal do conjunto, isto é, o contraste previsto para a entrada do malandro urbano se perde na profusão de eventos antes e depois, relativizando sua preponderância em meio à apresentação de todas as personagens centrais. ${ }^{70}$ Seguindo a linha "uniformizadora", o tema musical da entrada de Firmino é o mesmo da sequência dos pescadores, os "cânticos de puxada", mais uma vez, tendendo à uniformidade.

A intenção de acentuar a especificidade de Firmino é mais patente no trecho reescrito por Glauber, porque é amplificada pela reformulação dos elementos estruturais: a trilha sonora, a movimentação de câmera, a posição da sequência dentro do conjunto. A sequência toda é mais concisa: observe-se que Aruan e Naína, embora apareçam em referência manuscrita, foram cortados - a entrada de Aruan é adiada para o plano 41. A descrição da aparição de Firmino é datilografada em página avulsa, revelando um possível cuidado de reformulação.

Com relação ao acompanhamento sonoro, ao invés da continuidade dos cânticos de pesca, que teriam aplainado os planos de Firmino e os dos pescadores, optou-se pela fragmentação da trilha sonora - o apontamento é específico de "música marcante" descontinuidade repentina que causa uma estranheza anti-imersiva se pensarmos no filme: o espectador é desperto pelas rupturas bruscas da música. Antes que se possa embarcar no apelo estético do fenômeno antropológico, na idealização do trabalho coletivo, a duração do plano é subitamente interrompida pela chegada de um estranho, um malandro, embalado por sua música provocadora. Em última instância, "a forma" e "a montagem cinematográfica" se fazem sentir por atrito porque a oposição entre os

70 Optamos por não transcrever aqui, mas esse excerto é emoldurado por: plano 32, entrada do Mestre com seu apito, plano 33, entrada de Naína com tema de Iemanjá, plano 34, Aruan passa pela praia, plano 35, Naína segue Aruan pela praia, plano 36, arrastão, plano 37, entrada de Firmino, planos 38, 39 e 40, breve conversa entre Clara e Naína, plano 41, entrada de Cota, etc. 
planos é transferida também para elementos que normalmente estariam subordinados à imagem, invisíveis, como a música e a sucessão de planos.

$\mathrm{O}$ pequeno refrão que emoldura Firmino é um tema tradicional de capoeira cantado por um proeminente mestre capoeirista dos meados do século XX, o Mestre Canjiquinha (1925-1994), que compõe o elenco e aparece mais adiante, como percussionista na sequência do samba-de-roda. A estrutura em redondilhas desse canto popular é marcada pela ideia de jogo - pergunta e resposta, desdém e provocação: "Óia tu, que é moleque", e o coro devolve "moleque é tu", "cala a boca moleque", "moleque é tu". Embora empregue a mesma estrutura "cantador e coro" dos cantos de arrastão, não há no canto da capoeira o sentido conciliador da pesca, ou a vontade de coordenação do trabalho coletivo, ou ainda a chamada de grupo. A capoeira, sobretudo no contexto de Barravento, está ligada a uma conjuntura de oposição, luta, combate, e assume um caráter político, como veremos mais adiante. Poderíamos falar até em uma estrutura "cantador versus coro".

É preciso lembrar ainda que, enquanto manifestação cultural de matriz afrobrasileira, ligada a grupos sociais historicamente marginalizados dentro do espaço urbano, a capoeira também representa dentro do cânone cultural brasileiro uma forma de resistência popular à violência repressiva das forças policiais, ${ }^{71}$ algo de que Firmino nos dá notícia naquela fala inicial. De modo que a associação entre Firmino e o canto de capoeira nestes planos iniciais sublinha tanto características morais da personagem quanto sua urbanidade, e a aquele subtexto que compõe a personagem (indivíduo afrobrasileiro, malandro urbano, marginalizado, perseguido das forças de repressão, etc.).

Observe-se assim que nesse trecho e de forma progressiva ao longo da trama, a relação estabelecida entre planos e trilha sonora, não como mera emanação da cena, mas em favor do acirramento de tensões, e no limite, enquanto explicitação da própria montagem fílmica, ressoa como um dado brechtiano. Anatol Rosenfeld nos lembra a propósito do teatro épico:

A música, o texto e os outros elementos, longe de se apoiarem e intensificarem mutuamente para constituir uma síntese de grande efeito opiático, deveriam, ao contrário, comentar-se e criticar-se

71 A exemplo da lenda do capoeirista Besouro Mangangá (1895-1924), citado por Jorge Amado em Mar morto. Tratamos mais detidamente desse caso no Capítulo 1. 
reciprocamente, a fim de que o espectador não seja levado pelo caminho da empatia. ${ }^{72}$

Deve-se lembrar que, no panorama do Ciclo Baiano do Cinema, entre os anos 1958-1962, ${ }^{73}$ Barravento se distingue dos demais filmes, na radicalização e experimentalismo, pela total ausência de trilha sonora comentativa. A música do filme é exclusivamente composta por cantos de pesca de arrastão, pontos de candomblé, sambasde-roda e refrãos de capoeira. Em entrevista a Michel Ciment, Glauber afirma que se ocupou pessoalmente da gravação de alguns desses registros. ${ }^{74}$ Rosenfeld informa que Brecht também foi um incorporador dos gêneros tradicionais populares justamente como dado crítico anti-burguês, notadamente, na Ópera dos três vinténs. Contudo, ainda que Glauber e Brecht remetam a um contexto sociocultural de extração popular com suas fontes musicais, existem algumas diferenças fundamentais no sentido que produzem dentro de suas respectivas estruturas.

Antes de mais nada, a Ópera de Brecht é um musical. Música e ação se alternam e se interrompem mutuamente, ao passo que em Glauber Rocha a música obedece ao princípio de simultaneidade característico do cinema, ação e trilha estão sobrepostas. Outro fator, a música incorporada por Brecht passa por uma reelaboração formal de um compositor que impunha sua consciência crítica, ao passo que Glauber Rocha optou pelo uso do canto popular em sua forma mais direta, isto é, sem mediação a do compositor letrado. Walter Benjamin observa o papel dilatador da música no teatro épico, porque ela interrompe o fluxo imersivo dos acontecimentos para produzir a reflexão, como um fenômeno dialético: “[...] para o teatro épico a interrupção da ação está no primeiro plano. Nela reside a função formal das canções brechtianas, com seus estribilhos rudes e dilacerantes." 75

Essa concepção brechtiana colocaria algumas questões críticas para Barravento:

72 ROSENFELD, Anatol. Brecht e o teatro épico (org. Nanci Fernandes). São Paulo: Perspectiva, 2012, p.125.

73 Apud CARVALHO, Maria do Socorro Silva. A nova onda baiana: cinema da Bahia (1958-1962). Salvador: EDUFBA, 2003.

74 ROCHA, "Positif" in Revolução do Cinema Novo, 2004, p.115.

75 BENJAMIN, Walter. "Que é o teatro épico? Um estudo sobre Brecht." in Magia e técnica, arte e política: ensaios sobre literatura e história da cultura. Trad. Sergio Paulo Rouanet. São Paulo: Brasiliense, 1994, p.80. 
a) a incorporação dos cantos "brutos" de matriz popular (pesca, capoeira, candomblé), sem uma reelaboração discursiva explicitamente politizada, não geraria uma espécie de encantamento com a beleza antropológica do fenômeno, fazendo perder de vista a perspectiva crítica?

b) qual o interesse de integrar ao filme gêneros musicais populares tais e quais, se na sua concepção não necessariamente estão engajados com a reflexão política que o filme anuncia desde o princípio?

Com relação à primeira questão: $O$ canto de capoeira, o samba-de-roda (na modalidade de Barravento), os pontos de candomblé pertencem a um mesmo "gênero" que a teoria musical convencionou denominar "música modal”, aquela que se caracteriza pelo emprego cíclico e reiterativo de um único tom. É uma forma oriunda da tradição popular, comumente executada por instrumentos de percussão e voz. Por ser profundamente imersiva, na sua origem remota se mesclava à liturgia religiosa junto às sociedades antigas. ${ }^{76}$ Seu caráter circular é, no limite, hipnótico, não por acaso seu papel central na condução do "transe" dentro da ritualística do candomblé, por exemplo. ${ }^{77} \mathrm{~A}$ esse gênero se opõe a "música tonal", que na tradição do Ocidente representa o desenvolvimento discursivo da música pela incorporação de mais de um tom à estrutura da composição. A perda do caráter cíclico implica na criação de uma narrativa com notas. A trilha sonora de Barravento é exclusivamente modal, ao passo que a música em Brecht é tonal, de inspiração popular.

Se apostarmos na perspectiva crítica que o programa do filme de Glauber Rocha anuncia, é justamente o transe modal que seu autor quer evitar.

Fiz um filme contra candomblés, contra misticismos e, num plano de maior dimensão, contra a permanência de mitos numa época que exige lucidez, consciência crítica, ação objetiva. [...] O folclore e a beleza contagiante dos ritos negros são formas de alienação, são impedimentos

\footnotetext{
76 Os aspectos de teoria musical acima arrolados contaram com a sugestão e orientação da cantora de música popular brasileira Lilian Akemi Chinem, que nos instruiu a respeito do que sejam a música tonal e modal.

77 BASTIDE, O candomblé da Bahia - rito Nagô. Trad. Maria Isaura Pereira de Queiroz. São Paulo: Companhia Editorial Nacional, 1961.
} 
trágicos a uma tomada de consciência para a liberdade de uma raça importante em nosso século, como a negra. ${ }^{78}$

E ainda:

Poderemos, sem vergonha, empresar o exotismo da bela Bahia, procurando os ritmos do xaréu, os mistérios dos candomblés, a plasticidade da invasão? Aí não está nenhuma estética. Aí reside uma profunda imoralidade. ${ }^{79}$

De que forma, integrando o fenômeno da cultura popular em sua forma mais direta, como o canto modal, romper a rede encantatória da contemplação etnológica para estabelecer uma perspectiva crítica? Essa nos parece uma das ambiguidades fundamentais de Barravento.

A solução buscada pelo diretor gera, no interior da sequência mesmo, a tensão crítica. Ela se esboça na montagem fragmentária, na interrupção do universo cíclico pela intromissão de imagens alheias, pela personagem ao mesmo tempo interna e externa (Firmino), pelas rupturas e irregularidades - da ação, da luz, do espaço, da música -, pela própria mescla entre ficção e documentário. A sequência do roteiro acima apresentada ilustra essa estratégia. Na entrada de Firmino, a implosão da unidade da música da trilha assim como da linearidade do tempo (sem falar na qualidade da luz) configura uma espécie de ruído à narrativa fílmica tradicional.

A montagem em cacos de acontecimentos é em si mesma uma perspectiva crítica, porque propõe uma dificuldade de unidade, criando relações causais inusitadas entre as partes do conjunto: o que une a súbita chegada de um malandro da cidade e a circularidade da vida provinciana dos pescadores de Buraquinho?

Em um sentido mais amplo poderíamos transportar essa mesma lógica para o problema do gênero cinematográfico. Os quadros de pesca com seus não-atores têm um teor fortemente documental pelo evidente interesse antropológico da matéria, mesmo nos roteiros encontramos a palavra "documentário" a eles associada, ao passo que os quadros de Firmino apontam para o universo ficcional - a entrada de um ator inaugura uma

\footnotetext{
78 ROCHA, Glauber em Walter Lima Júnior, "Barravento no cinema brasileiro", Correio da Manhã, Rio de Janeiro (RJ), 17 abril 1962. 
narrativa imaginada, uma encenação. A oposição "documentário versus ficção" representa de outra forma uma questão premente para Glauber Rocha nesse momento: o complexo balanço entre "a busca de verdade social" (documental) e a "visão dialética" (o debate de ideias pela ficção).

Alguns anos após Barravento, Glauber debate o conceito de "cinema-verdade" a propósito das experiências cinematográficas de Chris Marker e Jean Rouch. ${ }^{80} \mathrm{O}$ conceito "cinema-verdade", segundo nos informa, surge como um derivativo das questões estéticas levantadas pela nouvelle vague na França, e diz respeito a um tipo de produção que se debruça sobre questões sociais, explicitando muitas vezes o fazer cinematográfico, a exemplo do filme Crônica de um verão (1961), de Jean Rouch et Edgar Morin.

Para Glauber Rocha, os documentários sociais de Marker, impregnados da sua formação como repórter de rádio e TV, são bem sucedidos por ampliarem a representação do fato social na forma de reflexão crítica. Jean Rouch, por outro lado, seria um etnólogo que coloca a forma cinematográfica a serviço do interesse científico. O estudo antropológico dos povos africanos resvalaria em um paternalismo no limite colonialista, um "esteticismo acadêmico", pois embora dê a conhecer ritos e costumes de sociedades locais ao mundo ocidental, não coloca em debate as questões políticas de sua matéria: os problemas sociais africanos, por exemplo.

Fica claro que o documentalismo da forma, no entender de Glauber Rocha, não desperta interesse se não trouxer para o centro o debate político, a crítica, a dialética, e se não provocar a ação revolucionária, que é do conteúdo mas também da forma - no que se alinha mais uma vez aos princípios brechtianos (princípio revolucionário + forma revolucionária e desalienante).

Mais adiante em sua exposição, Glauber reflete sobre a necessidade de uma verdade (que poderíamos chamar documental) na representação do povo no seio da ficção:

Quero explicar isso: Gustavo Dahl fez há pouco um artigo sobre o argumento cinematográfico em que analisa a linguagem, e diz, com muita propriedade, que o cinema, no momento em que esgota as suas possibilidades de linguagem e de pesquisa, passa a ser, de estético, ético. Fala sobre um problema colocado por André Bazin a respeito da 
imagem. Isso é muito importante. Um diretor que acredita na realidade, que pretende filmar um fato - falo de cinema de ficção - no local em que se passou a verdadeira ação, com ou sem atores, mas dentro de uma cenografia viva, captando ou não esse som, mas captando o som fundamental desse lugar, o som que mais representa, e as cores e os elementos, está fazendo um filme de verdade. É um diretor que acredita na imagem, que não vai para o estúdio fazer uma imagem forjada, num cenário forjado, acrescentando na imagem dados de alienação. Creio que tal colocação deve ser feita. O debate deve chegar ao problema da realidade. ${ }^{81}$

A maneira como a realidade antropológica se transforma em debate passa a ser um problema da forma. Em Barravento, mesmo um dos momentos mais documentais da filmagem não escapa à explicitação do artifício cinematográfico, rompendo a "quarta parede" da forma documental. Observem-se os fotogramas abaixo.
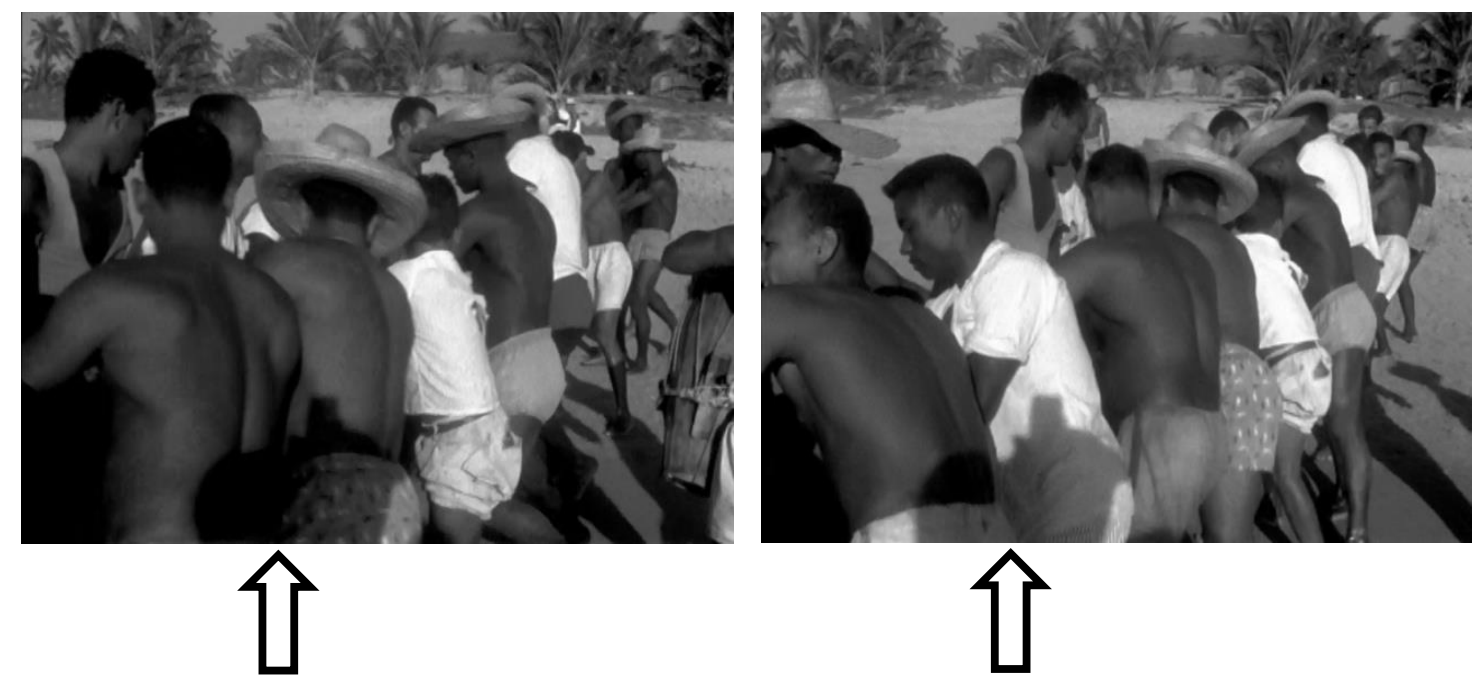

Nessa sequência, a sombra da câmera aparece no plano, no canto inferior esquerdo, se projetando sobre os corpos dos pescadores.

Acidente ou não, a "cenografia viva" com sua luz natural expôs o hors-champs no espaço documental, extrapolando a contemplação etnológica: o plano que poderíamos intitular a princípio de "a pesca tradicional de xaréu em Itapuã em 1960" coloca em cena 
a câmera como seu mediador, e passa a espelhar o próprio ato de filmar. Há um "narrador" que ao mesmo tempo em que documenta uma realidade social registra a si mesmo, com a câmera na mão, no ato de "contar".

A sombra da câmera presentifica no universo imagético o processo da linguagem fílmica, uma ambivalência da forma que já estava anunciada de maneira análoga no letreiro inicial, onde o filme se auto-refere como objeto de ficção ("Todos os personagens apresentados neste filme não têm relação com pessoas vivas ou mortas e isto será apenas mera coincidência. Os fatos contudo existem"). A sequência introdutória do filme explicita a multiplicidade das questões: não é apenas sobre os costumes dos pescadores, não é apenas sobre a chegada do homem da cidade, é também sobre o ato de filmar.

Não parece haver outros momentos de tamanha explicitação da câmera em Barravento, mas esse rastro sutil anuncia o gesto como uma outra dimensão interpretativa da maior importância - e mais uma vez, um traço brechtiano da construção. Seja o gesto da câmera, ou o gesto do ator.

Voltemos brevemente ao trecho do segundo roteiro que foi transcrito no começo desta análise: observemos o detalhamento do gestual que se desdobra na versão reescrita por Glauber. Entre o ato da "aparição de Firmino" propriamente dito ("salta por detrás do Farol") e a cuidadosa descrição da indumentária ("paletó, gravata, etc"), Glauber interpola o seguinte excerto: "Cai na areia da praia, equilibra-se, começa a andar, gingando o corpo, como malandro." Não seria talvez forçoso dizer que há um esboço de ritmo nessa interpolação. Ela parece imitar poeticamente a encenação:

De cima de uma pedra,

farol ao fundo,

salta Firmino.

Cai na areia da praia,

equilibra-se,

começa a andar,

gingando o corpo,

como malandro.

Em grandes linhas, a descrição situa o lugar do evento (farol), para em seguida encadear uma profusão de ações (saltar, cair, equilibrar-se, andar, gingar), e se conclui com uma indicação arquetípica (como um malandro). É evidente que o conjunto de gestos 
procura integrar uma corporalidade verossimilhante para sustentar o arquétipo. $\mathrm{O}$ malandro tem um corpo flexível e malicioso, ele se equilibra porque anda em terrenos perigosos, aparece tão súbito onde não foi chamado que beira o sobrenatural, se esgueirando por caminhos impróprios.

Antes de tudo, Firmino é uma corporalidade que ativa, junto ao imaginário do espectador minimamente familiarizado com a cultura popular brasileira, um certo repertório arquetípico (o malandro urbano, o Zé Pilintra, o sambista boêmio, o capoeirista), para dar-lhe mais adiante toda uma envergadura crítica. Glauber Rocha era consciente desse poder alusivo da encenação e o deixou registrado: "o mise-en-scène está fundamentado na coreografia popular dos passos e gingas daqueles capoeiristas latentes." $" 82$

Na medida em que a conotação política se acirra na tessitura do filme, com o aprofundamento da problemática da exploração e da alienação religiosa, não apenas o discurso mas também o corpo das personagens, sobretudo de Firmino, passará a evocar um gestus brechtiano mais exortativo, de que Anatol Rosenfeld nos informa:

Daí decorre a técnica do gestus, como chamava o uso de uma linguagem que deveria adaptar-se à atuação audiovisual da pessoa que fala ou canta. Típico gestus de Brecht é o do imperativo; o da exortação, advertência, perplexidade; o da pergunta e da surpresa. ${ }^{83}$

À ocasião da estreia brasileira de Barravento, o crítico de cinema Geraldo Portela no texto "Um gole de política" 84 chamou atenção para o caráter brechtiano do gesto de Firmino registrado no fotograma a seguir, quando os pescadores se dirigem resignados à praia para remendar a rede.

82 ROCHA, Cartas ao mundo (org. Ivana Bentes). São Paulo: Companhia das Letras, 1997, p.127. 83 ROSENFELD, op. cit. p.56.

84 PORTELA, Geraldo. "Um gole de política”, Diário de Notícias, Salvador (BA), 03 junho 1962, Suplemento. 


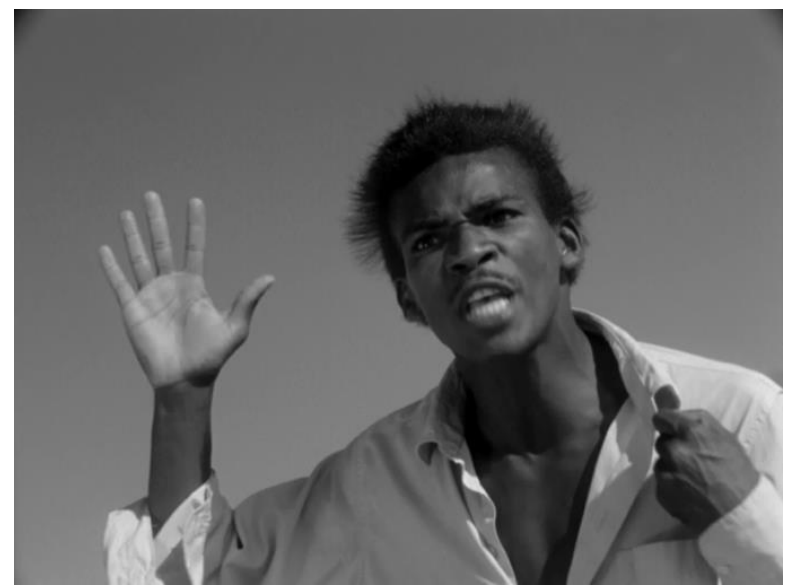

Firmino: Trabalha, cambada de besta, trabalha! Preto veio pra essa terra foi pra sofrer! Trabalha muito e não come nada. Menos eu que sou independente. Já larguei esse negócio de religião. Candomblé não resolve nada, nada, não! Precisamos é lutar. Resistir. Nossa hora tá chegando, irmão!

A personagem ocupa praticamente todo o quadro, a câmera em contre-plongée o ergue acima de nossos olhos, como em um púlpito. A palma da mão direita se mantém insistentemente elevada durante e depois do discurso. A ausência de outros elementos diegéticos no campo isola o quadro, não há qualquer referência espacial e ambiental, o que situa o espectador diretamente em contra-campo para Antonio Pitanga. Jean-Claude Bernardet observou a descontinuidade (proposital) da montagem, ${ }^{85}$ porque enquanto Pitanga discursa, é completamente ignorado pelos pescadores que seguem com o remendo da rede, ao ponto de haver uma disjunção entre os planos.

Em sua fala, Firmino incorpora uma série de registros, criando uma verdadeira colcha de retalhos discursiva. Ele parodia retoricamente um senso comum racista ("Preto veio pra essa terra foi pra sofrer"), se distancia do coletivo pela autoafirmação ("Menos eu que sou independente”), parodia o discurso revolucionário conclamando o coletivo ("Precisamos é lutar, resistir") e, finalmente, profetiza à maneira de um conselheiro ("Nossa hora tá chegando, irmão"). Entretanto, estaria Firmino no mesmo espaço diegético de seus conterrâneos? Para quem discursa de fato?

Observe-se a palma da mão erguida: símbolo do trabalho ou exortação, há uma duração insistente nesse gesto que escapa à naturalidade imersiva da narrativa, e que explicita a encenação, devolvendo o nosso olhar ao mundo real. $\mathrm{O}$ discurso passa a

85 BERNARDET, Jean-Claude. Brasil em Tempo de Cinema. Rio de Janeiro, Civilização Brasileira, 1967. 
transbordar do plano, é para o espectador que Firmino/Pitanga se dirige, e não mais para os pescadores - "a mão busca um pacto", dirá Geraldo Portela.

Walter Benjamin sublinha a materialidade e importância desse dado na prática teatral brechtiana:

O teatro épico é gestual. [...] O gesto é seu material, e a aplicação adequada desse material é sua tarefa. Em segundo lugar, em contraste com as ações iniciativas dos indivíduos, o gesto tem um começo determinável e um fim determinável. Esse caráter fechado, circunscrevendo numa moldura rigorosa cada um dos elementos de uma atitude que não obstante, como um todo, está escrita num fluxo vivo, constitui um dos fenômenos dialéticos mais fundamentais do gesto. ${ }^{86}$

O teórico nos dá uma pista: é preciso observar as transições do gesto, o seu começo e fim, para compreender, na amplitude dos contrastes, a visão dialética. Uma das sequências mais ricas em evoluções gestuais é a da luta final entre Firmino e Aruan.

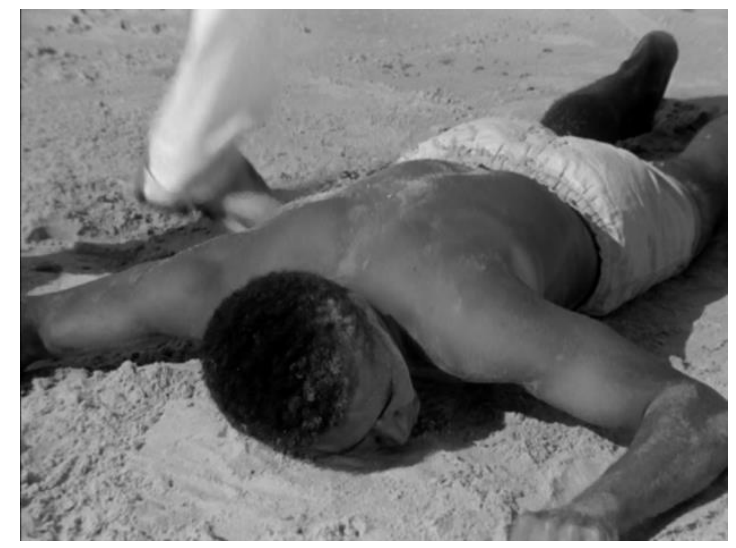

1 - Firmino chuta o corpo inerte de Aruan.

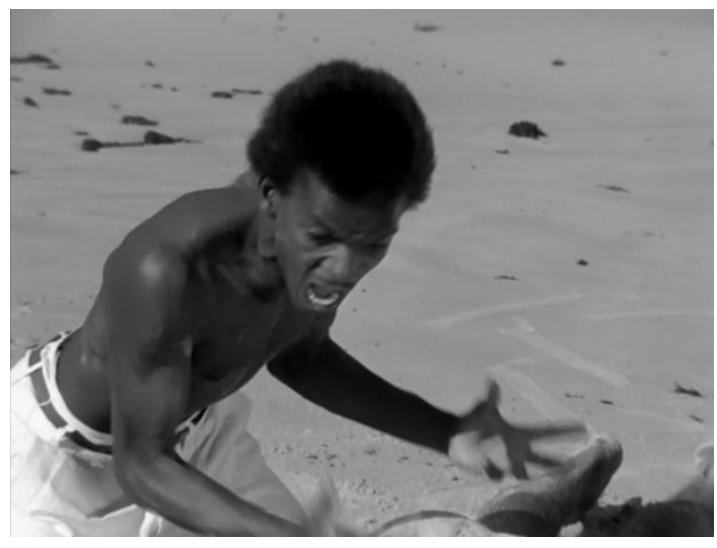

2 - Firmino se abaixa, fala a Aruan e fala ao povo. 


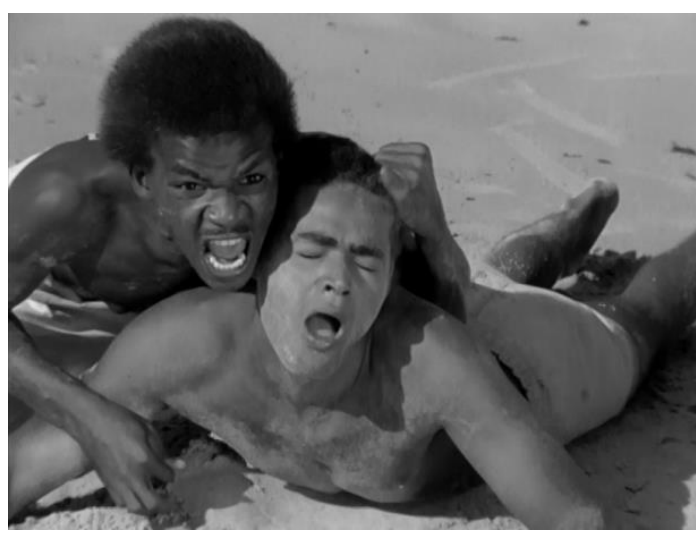

3 - A câmera assiste ao discurso de Firmino.

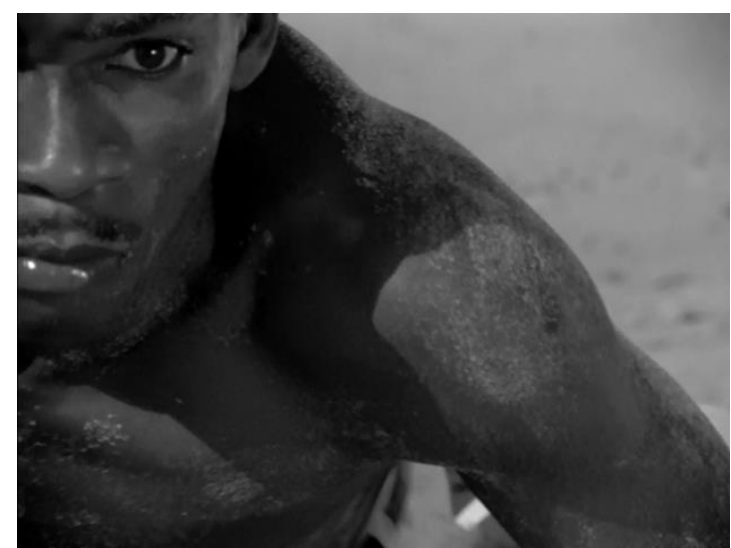

5 - A câmera se mantem próxima e registra a fúria que se dissipa.

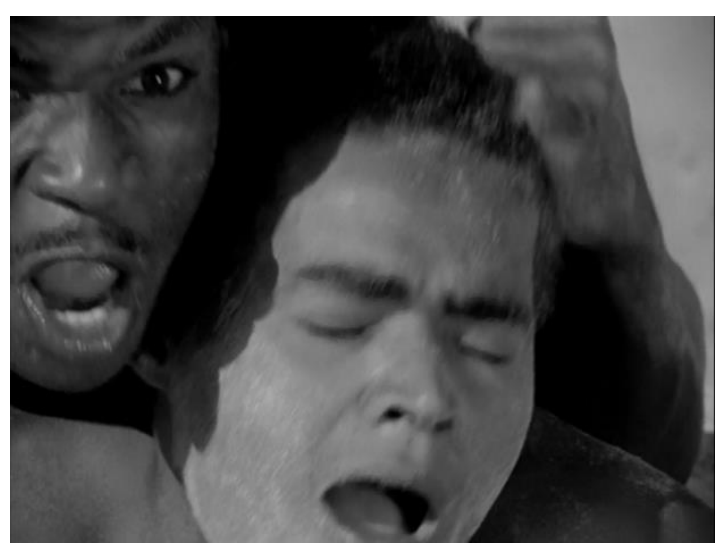

4 - Zoom-in sobre os dois rostos.

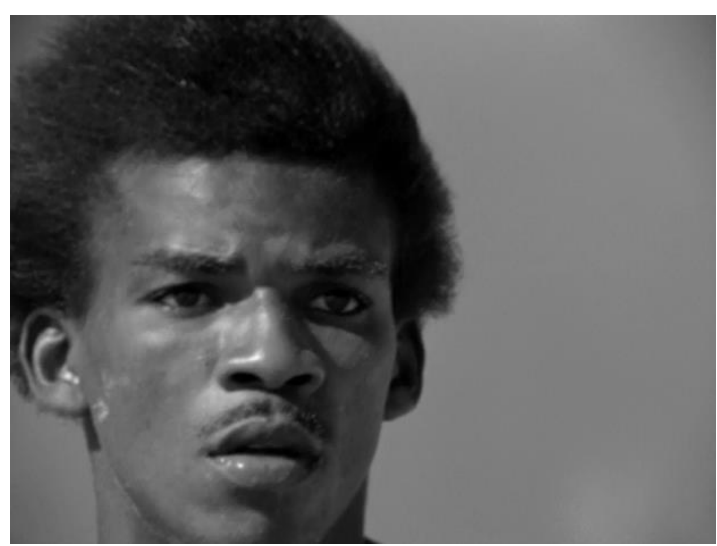

6 - Sem cortes, a câmera se ergue após

Firmino e enquadra seu rosto.

Firmino: Vou lhe deixar você vivo pra salvar o povo. É Aruan que vocês devem seguir. O Mestre não. O Mestre é um escravo! Yêee!

O trecho acima é a conclusão de uma explosiva sequência que se desencadeia com o embate final entre Aruan e Firmino, em um jogo de capoeira. Em alguma medida, é a descompressão decisiva das tensões entre os oponentes, e ao mesmo tempo, o momento em que suas existências convergem definitivamente, pois daí por diante, Aruan passa a aderir totalmente ao discurso anti-religioso de Firmino. Ele é subjugado pela força de suas próprias pulsões, mas fortalecido pelo ideal de luta contra as forças opressoras reais de exploração, Aruan se torna um homem secularizado.

Uma vez terminado o frenesi da luta, o jovem desvirginado é um ser carnal e seu rosto, agora distante da dignidade jovial ou da obediência tranquila, é um esgar de morte (3). O gesto de Firmino de pegar-lhe pelos cabelos é como o de mostrar a cabeça degolada do inimigo, decapitação que é retomada de forma mais literal em Deus e o diabo na terra 
do sol. Firmino está expondo a morte do Aruan espiritual, para deixar vivo o homem carnal desalienado.

Mais uma vez, contudo, o discurso não age sobre o povo, que atende à ordem do Mestre e conduz o corpo de Chico, totalmente indiferente às exortações do malandro. Do ponto de vista estrutural, a sequência isola Firmino, volta aquela impressão de que os pescadores não estão ocupando o mesmo espaço diegético. A câmera, contudo, que até então assistia inerte às elocuções de Firmino, passa a buscá-lo, reage e interage com sua combustão. Observe-se o uso do zoom em (4): para além de tornar a câmera visível, o zoom mergulha nos dois rostos levando o olhar abruptamente para dentro do discurso. Nele, a sintaxe explode, a linguagem não dá conta da fúria revolucionária, Firmino termina sua exortação com um urro para o espectador, como um grito clânico de guerra.

É importante notar que o plano não se conclui nesse momento. A câmera continua cerrada, aliada de Firmino, registra a dissipação da fúria, a exaustão do vitorioso, o fim da sua militância e lhe devolve um caráter vulnerável, cansado (5-6). Completa-se a entrada e a saída no discurso com mais um gesto: Firmino soergue o arpão que empunhava como arma no começo da sequência, para fincá-lo no solo. O objeto, como o discurso, também se transforma. De arma em símbolo. Ao estacá-lo, Firmino estabelece o limite de sua ação, deixando como legado aos pescadores o símbolo do seu trabalho.

A multiplicação brechtiana do gesto se cumpriu: a luta, o discurso e, por fim a distensão, como uma pausa analítica, em outras palavras, o corpo do ator produziu um crescendo, inocula a ideia crítica no momento ápice, e decresce. Tudo isso inscrito na totalidade de um "fluxo vivo", de que nos falava Benjamin - que poderíamos apontar em Barravento como a realidade histórica dos pescadores de xaréu, que preexistia e continuará depois dessa experiência ficcional.

Mas há também uma "encenação da câmera" que muda sua atitude com relação a Firmino. Ela por si só completa um clico reflexivo em torno da experiência que está em jogo. E, assim como entrou com Firmino no farol, sairá com Aruan. A experiência brechtiana se conclui quando o ciclo do êxodo se refaz.

Mas para que o caráter brechtiano se materialize em sua dialética, é preciso que a verossimilhança histórica desse êxodo se verifique, é o que passamos a analisar mais adiante.

\subsubsection{Firmino, o malandro}


Em estreita articulação com o caráter brechtiano da performance gestual, está a expressão "como malandro" na interpolação do roteiro glauberiano, com tudo o que esse arquétipo evoca na cultura popular e na tradição crítica brasileira. ${ }^{87} \mathrm{O}$ estudo analítico do malandro a partir da tradição literária passa necessariamente pela leitura dialética de Memórias de um sargento de milícias proposta em 1970 por Antonio Candido. Pensando em Barravento e na contemporaneidade com que o filme dialoga, que tipo de verdade histórica o malandro-Firmino nos permite intuir? Não se tratando aqui da sociedade monárquica oitocentista, é preciso investigar as reverberações da dinâmica social das classes pobres negro-mestiças, às quais o malandro remete a partir de sua complicada inserção na sociedade.

Barravento está emoldurado por um panorama histórico de transição na República Populista: o da metropolização das cidades brasileiras como consequência da "indução industrial" 88 ligada ao projeto nacional-desenvolvimentista e, em particular, seu grande impacto na Bahia. Um dos efeitos colaterais mais evidentes do surto urbano a partir dos anos 1950 é o êxodo, evocado diversas vezes no filme com maior ou menor otimismo.

No círculo de conversa das mulheres, Dona Clara constata: "Se os homens vão trabalhar na cidade não arranja nada, ninguém sabe fazer outra coisa, só sabe pescar e não tem gente grande pra proteger". Ao que outra mulher responde: "quando vim da seca do Norte pensei que aqui era melhor. É tudo igual. A fome come até os ossos da gente." A primeira fala dá conta de uma realidade histórica brasileira oriunda das clivagens sociais. É evidente que essas clivagens remontam ao sistema escravista, em que os indivíduos, muitas vezes sem oportunidade de trabalho em meio ao torvelinho das mudanças econômicas, precisam contar com a ajuda de poderosos, sem a qual estão jogados à própria sorte: “a relação com um proprietário - ou, no caso, com a polícia - permite aos personagens tirarem vantagens pessoais, pegando carona no poder do protetor [...]." 89

\footnotetext{
87 O termo "como um malandro" aparece desde o primeiro roteiro, ligado a Firmino, no descritivo de uma sequência posterior.

88 O termo é de Milton Santos em: A cidade nos países subdesenvolvidos. Rio de janeiro: Ed. Civilização Brasileira, 1965.

OTSUKA, Edu. "Espírito Rixoso: para uma reinterpretação das Memórias de um sargento de milícias." in Revista do Instituto de Estudos Brasileiros, Brasil, n. 44, p. 105-124, fev. 2007, p.121.
} 
A segunda fala, por sua vez, trata da perpetuação da miséria, e do êxodo como ilusão de melhoria de vida: a fome do pobre igualando as diferenças regionais. Há contudo, um deslocamento curioso, pois a personagem apresenta um êxodo atípico entre o sertão e o litoral provinciano (Itapuã), e não para o litoral urbanizado das capitais industrializadas. Aqui cabe lembrar que, à época em que se passa a trama, Itapuã vivia seu crepúsculo como província. Antes uma região de difícil acesso, seria dali a pouco aglutinada pelo processo de expansão urbana de Salvador. ${ }^{90}$

Em outro passo, mais precisamente na cena final do filme, o abandono da província aparece como horizonte: a esperança de aquisição dos meios de produção (ganhar dinheiro na cidade e comprar a rede) de modo a superar a opressão econômica sobre as populações locais.

O que há no filme de esperança não me pertence mas sim ao fabuloso Canjiquinha quando canta:

"Vou pra Bahia pra ver se o dinheiro corre

Se o dinheiro não correr

Ai, Deus, ai

De fome ninguém não morre" 91

Assim como na abertura, o trecho cantado final vem participar na cena como expressão de relações latentes, anunciando uma esperança com a qual Glauber textualmente não adere. $\mathrm{O}$ estribilho passa a traduzir a consciência da personagem e a expectativa menos de prosperidade que de uma subvida precarizada na cidade. A capital não oferece garantia alguma de ascensão social mas, ainda que o dinheiro não corra, ninguém morre de fome, a fome estando ligada ao sertão, ao interior. É uma possibilidade de sobrevivência.

90 RISÉRIO, Antonio. Caymmi: uma utopia de lugar. São Paulo: Perspectiva, 1993. (Debates; v.253), p.71: “[...] eram verdadeiras casas vegetais se espalhando entre o mar azul e as dunas da lagoa de Abaité. E esta Itapuã, com seus bailes pastoris e suas "ganhadeiras", seus ternos e seus batuques, parecia parada no tempo, levando vida de algum sabor tribal. Salvador, naquela época, terminava em Amaralina. A comunicação terrestre com Itapuã só era possível na maré vazante, já que a maré-cheia, represando o Rio Jaguaripe, bloqueva a passagem.”

91 ROCHA, Glauber. “Experiência 'Barravento’: confissão sem moldura”. Diário de notícias de Salvador. 25-26 de 1960, p.6. 
Aruan vai reincidir no caminho aberto por Firmino como o cumprimento de uma espécie de rito de maturidade. Da província, infância da consciência alienada, para uma vida madura e secular, nas frestas da massa urbana. Firmino é, como se pode constatar, uma espécie de figura arquetípica do deslocamento, mentor do êxodo e da adaptação às circunstâncias. A adaptação está posta na acumulação de categorias que o compõem, como foi dito anteriormente - categorias do trabalho, do seu substrato cultural afrobrasileiro e do atribulado percurso social: ex-pescador de Itapuã, homem neourbano, capoeirista subversivo, traficante ilegal de cargas, candomblezeiro nas urgências, sambista e boêmio. A partir daí, pode-se pensar na movimentação que teria ocasionado esse amontoamento de atributos, e como eles refletem uma imposição das acomodações econômicas dos anos 1950-1960, com choques sociais particularmente importantes para as camadas menos favorecidas.

Isso porque, para os "Firminos" Bispo dos Santos, a precarização do trabalho e das condições de vida se dá em múltiplas frentes, correspondendo à mudança da relação entre dois espaços geográficos distintos:

a) a província, com seus meios de produção defasados, sofre a pressão da modernização econômica - a miséria se agrava na medida em que as imposições econômicas invadem os antigos redutos de modos de produção tradicionais com dinâmicas de exploração modernas, urbanas e mais agressivas. Em Barravento, isso é ilustrado pela relação entre pescadores e o dono das redes. Nos curtas-metragens praieiros de Robatto Filho, vê-se ao fim a rodovia, recém chegada a Itapuã, que romperá seu cerco provinciano. $\mathrm{O}$ acirramento da miséria da província se mostra como o outro lado da moeda do crescimento e concentração de riqueza na cidade.

b) nas capitais, a metropolização não garante emprego para as massas migratórias evadidas da penúria dos sertões - e do litoral (pesqueiro), que Barravento retrata. Em Salvador, portanto, não se configura necessariamente um processo de proletarização das massas, mas o acúmulo de população em condições marginais, paralelamente à concentração de riqueza que provém dos lucros, por exemplo, da exploração agrícola - sobretudo do cacau, que representava em 1954 70\% da economia da Bahia. $^{92}$ A proletarização é tanto menor quanto, na marcha da industrialização brasileira, a Bahia não se equiparará em dinamismo com outros estados, principalmente

92 SANTOS, Milton. O centro da cidade de Salvador: Estudo de geografia urbana. São Paulo: Editora da Universidade de São Paulo; Salvador: EDUFBA, 2008. p.78. 
São Paulo. ${ }^{93}$ Em suma, a capital baiana não consegue absorver o excedente de mão-deobra com uma população que, a partir dos anos 1950, passa a crescer em uma média de 15 mil habitantes por ano. ${ }^{94}$

Milton Santos, em “A cidade nos países subdesenvolvidos”, informa:

Não é de admirar, por conseguinte, a proliferação, na cidade, de inúmeras formas de subemprego, ao lado do desemprego declarado. Uma grande porcentagem da população vive de rendimentos ocasionais, de biscates. Estes, e os que não trabalham, vivem, praticamente, às custas dos que têm uma atividade: é o famoso parasitismo urbano do mundo subdesenvolvido. [...] Em Salvador, em 1950, a população ativa era apenas $47 \%$ da população com mais de 10 anos. ${ }^{95}$

Com efeito, a rigorosa estratificação da Bahia neometropolitana dos anos 1950 é apontada pelo geógrafo:

1. as classes altas, formadas:

a. pela aristocracia da terra;

b. pela nova classe dos industriais, comerciantes, especuladores de todo tipo e "novos ricos da terra";

2. as classes médias:

a. a alta classe média, que participa dos modos de vida da alta classe, sem, entretanto, contar com os mesmos rendimentos;

b. a baixa classe média;

3. as classes pobres, entre as quais:

a. os pobres propriamente ditos, que dispõem de um emprego modesto, mas fixo, como os operários e pequenos comerciários;

b. os muito pobres ou miseráveis, que vivem do dia a dia.

93 Milton Santos nos fala de 100 bilhões de cruzeiros em produção industrial em São Paulo contra 2,6 bilhões da Bahia, e de 440 mil operários na capital paulista contra 15 mil em Salvador, em meados dos anos 1950. SANTOS, op. cit., p.51.

SANTOS, A cidade nos países subdesenvolvidos. Rio de janeiro: Ed. Civilização Brasileira, 1965, p.9. 
É evidente que o malandro Firmino ocuparia o último estrato - "os muitos pobres ou miseráveis, que vivem do dia a dia", abaixo ainda daqueles que dispunham de empregos modestos, como os $25 \%$ da população que trabalhavam como domésticos à mesma época. ${ }^{96}$ A esse respeito, o discurso de Firmino apresenta duas feições:

Isso é pra quem pode (referindo-se à roupa). Vocês arrastam rede todo dia sabe pra quê? Pra meter dinheiro na barriga de branco. Eles tão tudo rico nas suas costas. A mim é que ninguém explora mais. Agora só trabalho por minha conta e não tenho hora marcada. Corro risco, mas sou livre como um xaréu no mar. Mas só que ninguém apanha o papai. Se vocês soubessem ao menos assinar o nome, mas não adianta não, vocês são analfabetos. É pensar que o mundo é tudo na base da miséria.

Em um primeiro momento, Firmino dá a entender que a ilegalidade é um preço pequeno a ser pago pelas vantagens de liberar-se do regime de exploração do trabalho, e que os colegas não podem almejar a mesma liberdade por falta de educação formal. Estão aprisionados à escassez material da província. Entretanto, em momentos mais intimistas, o malandro deixa entrever outro aspecto, muito menos positivo, dessa realidade:

Se as coisas fossem diferentes eu até que me arrumava. [...] A renda mal serve pra ter uns panos decentes em cima do corpo. Eu estou sem oportunidade, como diz um amigo. A ficha na polícia anda muito descarregada. E agora inventaram até uma palavra nova: elemento subversivo.

"Se as coisas fossem diferentes eu até que me arrumava" indica que a incursão na ilegalidade é muito menos eletiva do que parecia a princípio. Torna-se uma alternativa de sobrevivência, uma vez que a promessa de aquisição de bens de consumo e melhoria material se desmantela na realidade nefasta das circunstâncias.

Originalmente, o filme apresentava ainda outros dados desse retrato social. Há na primeira versão do roteiro o que seria uma das poucas interações entre Firmino e Naína, jamais realizada. Na sequência 49 (planos 449-464), Firmino convidaria Naína a 
acompanhá-lo de volta à cidade. A oferta é maliciosa, entre trabalho doméstico e prostituição:

[...] esses retirantes dirigiam-se para Salvador na esperança de encontrar aí melhores condições de vida. Mas, afinal, a maioria se empregava como domésticos em casas de famílias abastadas ou da classe média, ou então se entregavam a toda espécie de parasitismo urbano. ${ }^{97}$

Na mesma versão do roteiro, Firmino usa o êxodo como elemento de permuta para instrumentalizar Cota (sequência 51, plano 468: "Olha, mulher, se você quizé fazer uma coisa lhe carrego comigo pra cidade"; Cota: "Então diz logo. Há muito tempo que tou doida pra isso"). Isto é, o malandro faz as vezes de um agenciador do êxodo e da subproletarização, do trabalho doméstico ao meretrício, em uma lógica de reprodutor de subempregos, como um excluído que dissemina exclusão.

Ainda que esses excertos não tenham sido incluídos em Barravento, que se mostra em sua montagem final mais elíptico, é essencial desnaturalizar o caráter arquetípico do "malandro" e compreendê-lo dentro desse rearranjo sócio-econômico do Brasil dos anos 1950-60, em meio à metropolização e explosão demográfica das capitais. E ainda, proporcionalmente à exclusão social, o crescente aparelhamento de mecanismos de repressão. Firmino o deixa entrever quando enuncia a expressão "elemento subversivo", que então lhe parece como uma nova denominação.

Para além do samba e da boemia, aspectos carismáticos do malandro urbano arquetípico, o malandro glauberiano se afasta da "comicidade popularesca"98 para manifestar-se em sua contraface violenta e antipática, como uma resposta funesta aos mecanismos de opressão econômicos e à dupla exclusão social: ele foi desnaturado de sua terra natal pela atração da cidade (a aquisição de bens, a providência material), mas vive na cidade o extremo grau da marginalização e o cotidiano da violência, que o obrigam ao retorno constante ao ponto de partida. Ele vai disseminando, no seu percurso, a violência dos processos mas também, e esse é um dado da teatralidade, um discurso carregado de consciência histórica de classe.

$97 \quad$ SANTOS, 2008, p.45-46.

98 O termo é emprestado de Antonio Candido, "Dialética da malandragem", in O Discurso e a Cidade. São Paulo: Duas cidades, 1993. p.71. 
A perda do temperamento simpático se explica ainda pelo seu modo de ação específico. Câmara Cascudo, ao tratar do malandro tradicional (Pedro Malasarte), detecta a raiz carismática de sua ação: "É o tipo da inteligência despudorada e vitoriosa sobre os crédulos, os avarentos, os parvos, os orgulhosos, os ricos, os vaidosos, expressões garantidoras da simpatia pelo herói sem caráter." 99 As artimanhas de Firmino se dirigem na prática muito menos diretamente aos poderosos do que aos oprimidos, o que se explica, de outra forma, pela mudança do campo de ação desse malandro urbano, afastado da classe econômica favorecida.

Não seria Firmino uma espécie de manifestação do "espírito rixoso" de que nos fala Edu Otsuka, aclimatado às dinâmicas sociais das novas metrópoles?

\begin{abstract}
Não se trata, portanto, de uma inclinação "natural" dos pobres que, abandonados a si mesmos, entregam-se aos impulsos violentos, mas sim de um padrão de comportamento socialmente mediado - e em última instância determinado pela evolução moderna da economia [...] o núcleo de violência próprio aos movimentos de expansão capitalista. ${ }^{100}$
\end{abstract}

Firmino, colocando em evidência a manutenção de uma ordem social excludente que remonta ao passado colonial, traz consigo atualizações importantes também da ordem da representação do malandro, justamente por ser não mais um integrante da classe pobre branca. O malandro urbano glauberiano passa a ser um homem negro organicamente vinculado à cultura afro-brasileira. E ele vai caminhar simultaneamente dentro da contemporaneidade histórica e do fenômeno cultural popular, ao ponto de encontrar seu correspondente místico dentro das matrizes religiosas afro-brasileiras: o Exu.

\title{
2.2.2. Firmino, o Exu
}

Ao lado do conjunto de verossimilhanças históricas e dados formais que compõem Firmino, existe ainda um outro eixo que o rege e amplifica a ambivalência de

99 CASCUDO, Luís da Câmara. Dicionário do folclore brasileiro. São Paulo: Global, 2012, p.417. milícias." in Revista do Instituto de Estudos Brasileiros, Brasil, n. 44, p. 105-124, fev. 2007, p. 124 
sua ação: uma matriz mística que não apenas se manifesta como parte do substrato cultural da personagem, mas que em mais de um momento orienta a narrativa. Isso porque, no dizer de Ismail Xavier, Barravento tem um "caráter barroco", apontando para mais de uma direção simultaneamente - uma linha interpretativa não refuta a outra. ${ }^{101} \mathrm{Em}$ correspondência a Paulo Emílio Sales Gomes o próprio Glauber Rocha indica essa simultaneidade: "Um preto da mesma idade de Aruan, Firmino, tido como 'gente do Exú', detesta o mar e veio para a cidade". ${ }^{102}$ Essa frase do diretor patenteia, ao mesmo tempo, uma narrativa histórica da personagem e sua inserção no universo espiritual.

Assim, concluímos a investigação de Firmino, considerando-o além de homem urbano e malandro brechtiano, como manifestação de Exu, e de que formas Barravento sustenta, contraditoriamente à sua perspectiva crítica da religião, essa função mística. Cabe dizer, aliás, que a relação entre a identidade urbana marginalizada e a representação de Exu encontram fortes convergências pela forma como o sincretismo afro-brasileiro assimilou a realidade histórica da metropolização:

\begin{abstract}
Na umbanda, o espírito desse malandro, boêmio amante da noite e da rua, que geralmente morre assassinado por faca ou tiro numa briga por mulher, dívida de jogo ou outro vício, é cultuado como Zé Pilintra. Esta entidade é um tipo de Exu urbano, das zonas portuárias e das áreas de meretrício, assim como as Pombagiras. Veste-se, entretanto, com paletó, calça e sapatos brancos e gravata e lenço vermelhos. Sua vestimenta impecável é uma forma de ludibriar sua condição de pobre e marginal social e chamar a atenção para si como sujeito que não tem propriamente um lugar na estrutura social excludente da sociedade brasileira. ${ }^{103}$
\end{abstract}

O trecho acima praticamente retoma tanto a descrição de Firmino no enredo de Glauber pela indumentária quanto a sua narrativa intrínseca de exclusão. Mas as relações entre Barravento e Exu nem sempre são tão elípticas. As menções ao Orixá/entidade

\footnotetext{
101 Essa afirmação é feita por Ismail Xavier em depoimento no disco 2 do DVD de Barravento, na seção "Barravento visto por". ROCHA, Revolução do cinema novo, p.126

103 SILVA, Vagner Gonçalves da. "Exu do Brasil: tropos de uma identidade afro-brasileira nos trópicos”. Revista De Antropologia, Brasil, n. 55, p.1085-1114, jul. 2013. p.1105.
} 
aparecem de maneira explícita no primeiro roteiro. Na sequência 40 (planos 361-376), momento em que o mandatário vem buscar as redes com a carroça e Firmino tenta incitar os pescadores à resistência, há um primeiro embate contra Aruan. Nessa versão da cena, que não foi incluída tal e qual, os pescadores se interpunham e Dona Clara, de fora, fazia uma sugestiva declaração:

\section{SEQUÊNCIA 40-EXTERIOR-DIA-PRAIA-LEVADA DA REDE- CARROÇA:}

$[\ldots]$

p.39

\begin{tabular}{|l|l|l|}
\hline 373- & $\begin{array}{l}\text { Firmino abatido vai se recom- } \\
\text { pondo e ainda fala de longe }\end{array}$ & $\begin{array}{l}\text { Firmino: Meu consolo é que } \\
\text { sem rêde, vocês vão } \\
\text { acabá é pedindo } \\
\text { esmola..... }\end{array}$ \\
\hline $374-$ & $\begin{array}{l}\text { As mulheres em pe.'Firmino } \\
\text { passa,elas gritam Firmino } \\
\text { sai fazendo sinais }\end{array}$ & $\begin{array}{l}\text { Mulheres:Bota a tua boca } \\
\text { na maré d e va- } \\
\text { sante,infeliz do } \\
\text { pé chato. }\end{array}$ \\
\hline $375-$ & Clara comenta com Naína & Clara:Esse Firmino,até pare \\
\hline
\end{tabular}

p.40

ce encarnação de Exú.

O trecho acima está entremeado por uma atmosfera premonitória: quando a carroça parte, o vento zune, o Mestre declara que o tempo vai virar, em suma, o barravento se anuncia. A personagem que faz a asserção, Dona Clara, é secundária na narrativa. Interpretada por uma não-atriz, suas interações estão ligadas, de um modo geral, a evocações do universo iorubá, e suas falas representam a consciência de um indivíduo sensitivo e iniciado nos mistérios do candomblé, que assiste no plano do real às causas de ordem espiritual. É Dona Clara quem primeiro convida Naína para o terreiro, dizendo que sua estranha melancolia parecia "coisa feita". No trecho acima, ela exerce o papel de um intérprete externo ao foco da ação que detecta em Firmino um farejador de contendas, um açulador dos conflitos à semelhança de determinado Orixá. 
Mas o que justificaria nesse excerto a associação entre Firmino e o Exu iorubano? Certamente, isso se deve ao paralelismo entre o caráter e o conjunto das ações do malandro e o arquétipo do Orixá dentro da cosmovisão iorubana, ${ }^{104}$ onde ocupa uma posição de fundamental importância:

O cosmos está dividido em quatro compartimentos. Um sacerdote especial tem a seu cargo cada um deles. [...] E todavia o cosmos é obra de um único deus criador, Olorum. É preciso, pois, que a divisão não suprima tal unidade; é preciso que os quatro compartimentos se liguem entre si. E quem poderia consegui-lo melhor do que Exú, que abre as portas e traça os caminhos? [...] Vai praticar aberturas entre os quatro reinos, furar as paredes estanques que os separam uns dos outros, fazendo-os, por seu intermédio, entrarem em comunicação e assegurando assim a união cósmica. Exú é, para nós, o elemento dialético do cosmos. ${ }^{105}$

Em $O$ Candomblé da Bahia, Roger Bastide dedica um capítulo ao retrato de Exu no qual apresenta um quadro complexo de concepções ligadas a esse Orixá e seu modo de ação dentro das esferas do mundo. Segundo o sociólogo, a cosmovisão iorubana percebe o mundo a partir de uma quádrupla divisão de domínios, aos quais, em sua complexidade interna, correspondem certos tipos de sacerdócio:

a. o domínio das ervas, da natureza viva intocada pela ação humana, onde habita a divindade conhecedora das propriedades mágicas das plantas, Ossaim (Ossanha), a cargo do sacerdote babalossaim;

b. o domínio relativo aos destinos dos homens e suas relações, das causas humanas, a cargo do babalấ;

104 Exu é uma divindade ligada à cosmovisão de matriz iorubana, a que se liga, no Brasil, a Nação Ketu do candomblé brasileiro. Existem ainda as nações Jeje e Angola, nas quais Exu encontra seus correlatos ewe-fon e banto, denominados respectivamente Legba e Aluvaiá. Há entre eles pouca variação. Bastide informa: “O caráter sexual de Exú é sem dúvida menos pronunciado do que o de Legba, mas as duas divindades, a divindade Yoruba e a Fon, acabaram por se confundir ainda mesmo na África e, com maior razão, no Brasil [...]”. in BASTIDE, Roger. O Candomblé da Bahia - Rito Nagô. Trad. Maria Isaura Pereira de Queiroz. São Paulo: Companhia Editorial Nacional, 1961. p.210. O candomblé de Barravento é certamente de nação Ketu. 
c. o domínio intangível dos deuses, Orixás, cuja ritualística é conhecida do babalorixá ou da ialorixá;

d. o domínio profundo dos mortos e ancestrais, os Eguns, com sua ritualística secreta a cargo do babaojé.

Nessa concepção, cada um dos quatro compartimentos do real compõe a totalidade do mundo sem se imiscuir em seus ritos e doutrinas, como diferentes campos do conhecimento, razão pela qual exigem sacerdócios distintos.

Exu seria o Orixá capaz de circular entre os quatro planos, e agir em cada um deles simultaneamente: "[fazendo] participar entre si os compartimentos do real. Ele é o único Orixá que tem um pé em cada um desses compartimentos.", ${ }^{106}$ porque "é ele, e somente ele que representa o princípio da dialética e da intercomunicação." ${ }^{107}$ Tal como o Hermes da tradição greco-latina, Exu encarnaria o mensageiro da mitologia iorubana, versado tanto na língua dos deuses quanto na língua dos homens, traduzindo para os mortais o desígnio dos imortais e vice-versa.

Por estar no limite entre os quatro domínios sua presença é sempre inaugural, de modo que toda liturgia candomblezeira começa necessariamente com o ipadê, um ritual que convida Exu a tomar parte e derrubar as barreiras entre os mundos (e não para despachá-lo, como se diz equivocamente). Por extensão, é uma divindade vigia dos portais, abridora de caminhos, executora das transições, habitante das zonas fronteiriças, de onde sua associação simbólico-espacial com a encruzilhada. É o que procuramos ilustrar no esquema abaixo:

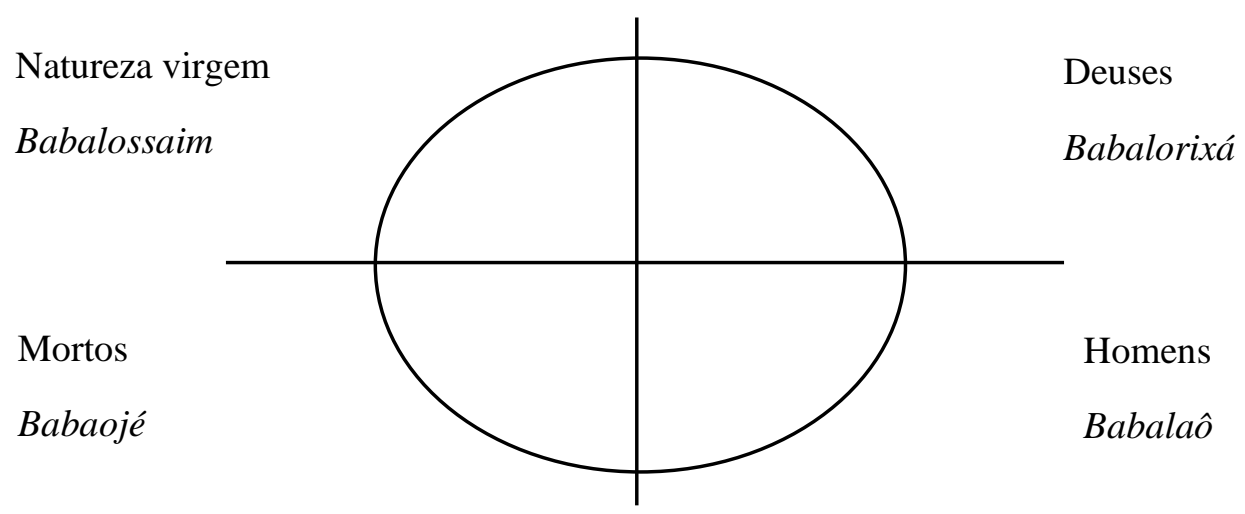

\footnotetext{
$106 \quad$ BASTIDE, op. cit., p.230.

107 Ibid., p.243.
} 
Contrariamente à sua função benéfica e conectora, o caráter de Exu é comumente ligado à desordem, à malícia, à violência e à artimanha. Roger Bastide evoca o termo "trickster", que foi tradicionalmente associado a Exu por alguns etnólogos e africanistas. ${ }^{108}$ Curiosamente, é um termo lembrado por Antonio Candido a propósito do malandro. Risério, por sua vez, faz a fusão do malandro e do Orixá, ao denominar Exu o "malandro divino", e vai mais longe: "Exu-Legbá [...] é a encarnação da verdadeira e sagrada dialética da malandragem. É jovem e velho, alto e baixo, cordial e violento. Personificação da luxúria, da contradição, da oralidade insaciável." ${ }^{109}$ A contradição entre a ação salutar da comunicação e a hostilidade do conflito não seria talvez mais do que aparente se levarmos em conta que a ruptura com a rigidez das estruturas do mundo exigiria uma ação enérgica, revolucionária, iconoclástica.

Se, contrariamente à sua finalidade essencial, parece algumas vezes introduzir a desordem, as brigas, a desventura no mundo divino ou humano, isto não passa do reverso de um equilíbrio sôbre o qual vela com tanto cuidado. ${ }^{110}$

Ou, dito de outra forma, ao transitar entre os domínios opostos do real, Exu seria o Orixá que melhor incorporaria a visão dialética do mundo. Diz um dos contos por ele protagonizado:

\footnotetext{
São muitas as tramoias de Exú

Exú pode fazer contra,

Exú pode fazer a favor.

Exu faz o que faz, é o que é. ${ }^{11}$
}

Soma-se a essa energia naturalmente subversiva, o sincretismo exercido historicamente pela tradição cristã, como de um diabo, uma manifestação demoníaca.

\footnotetext{
108 PELTON, Robert D. The Trickster in West Africa: A Study of Mythic Irony and Sacred Delight. California: California University Press, 1989, apud BASTIDE, op. cit., p.208. p. 165 .

110 BASTIDE, op. cit., p.241.

111 PRANDI, Reginaldo. Mitologia dos Orixás. São Paulo: Companhia das Letras, 2001, p.70.
} 
Roger Bastide indica, através de seus informantes, que tal sincretismo proviria em grande medida da associação, por parte das elites coloniais brancas, do caráter indomável do Orixá às revoltas de escravizados insubordinados contra o regime de opressão.

São dados que vão alimentando a base comum entre o Firmino de Glauber Rocha e o arquetípico Exu da mitologia iorubana. O malandro, desde a sua entrada, se situa física e simbolicamente no limiar entre universos, a cidade e a província, o passadismo e o moderno, o conservadorismo tradicional e a discursividade revolucionária. Ele provoca o choque entre essas estruturas duais estanques e o verbaliza, prolixamente, fazendo vislumbrar deste lado (a província) o incomunicável do outro lado (a cidade), ou tornando visíveis na província as pressões do processo urbano. "Sem sua participação não existe movimento, mudança", ${ }^{112}$ diz Prandi a respeito de Exu, mas poderíamos facilmente colar essa frase à militância de Firmino.

É, aliás, a própria definição do barravento no letreiro do filme: "Barravento é o momento da violência, quando as coisas de terra e de mar se transformam, quando no amor, na vida, e no meio social ocorrem súbitas mudanças”. Observe-se como esse enunciado arrola certos domínios do real para a concepção iorubana: o mar, como representação da natureza viva (babalossaim) e o domínio da divindade (babalorixá); a terra, o amor e a sociedade como território dos homens e seu destino (babalâ̂), faltando apenas a morte e os ancestrais (babalojé), que se farão contudo presentes no desenlace da trama. Basta lembrarmos que, no âmbito da vida comunitária, o filme se conclui com um axexé, o rito fúnebre do candomblé.

A ação insistente de Firmino conecta domínios de outra forma inconciliáveis. Assim, a realização carnal do amor de Cota por Aruan está intimamente ligada à morte, do Seu Vicente e da própria Cota, e o anúncio da morte de Chico, na mesmíssima ocasião, é praticamente simultâneo ao nascimento do seu filho.

Como uma espécie de força propulsora desses eventos, é de grande importância a incitação ao sexo na ação de Firmino. Até então, o malandro vinha escancarando a contradição de seu caráter pelo desencontro de suas estratégias, ora ligadas a um plano de ação místico (um ebó) ora material (furar a rede). Mas é somente pela via do sexo e do desvirginamento do herói que ele alcança seu objetivo dessacralizador. Em última instância, é a “quebra do coité de Aruan”, nas suas próprias palavras, que vai corroer os limites da ordem tradicional.

$112 \quad$ PRANDI, op. cit. p.21. 
Retomemos aqui brevemente a sequência analisada por Ismail Xavier em Sertão mar, ${ }^{113}$ aquela em que Aruan desperta sozinho na praia após o desvirginamento. A câmera contempla o jovem satisfeito, em plena possessão de sua virilidade, e segue para um movimento ascensional, percorrendo em "L" um coqueiro até o céu, onde explode o barravento. Essa sequência efetua, pela correlação de imagens, a ligação entre os planos da terra e do céu, das ações humanas e do desígnio divino. O coqueiro, símbolo fálico, passa a exprimir metaforicamente a realização da virilidade, assim como o barravento é a explosão da energia sexual, o gozo.

Ora, um dos principais apetrechos de Exu é justamente um porrete fálico, comumente em "L". ${ }^{114}$ A ação artimanhosa desse Orixá, "dono do falo magnífico", ${ }^{115}$ está também ligada à distensão sexual como forma de ruptura dos cercos constritores das ordens. A câmera de Barravento, ao aderir a esse repertório imagético, passa a sublinhar relações causais de ordem mística.

Há outros dados estruturais do filme que caminham na mesma direção.

Voltemos àquele trecho do roteiro que foi transcrito acima para evidenciar algumas mudanças. A sequência do filme como conhecemos dispensa tanto a presença das mulheres espectadoras da cena quanto a afirmação de Dona Clara (“esse Firmino, até parece encarnação de Exú"). O que significa que o diretor preferiu subtrair participações subalternas em favor da concentração no foco da ação (a recolha da rede). Resta-nos o discurso abrasivo de Firmino, repleto de incitação revolucionária, seu gestual e a performance brechtiana. O acirramento da conotação política da cena não subtraiu, contudo, o simbolismo místico, que permanece implícito nas relações espaciais.

\footnotetext{
113 "Barravento: alienação versus identidade" in XAVIER, Ismail. Sertão mar: Glauber Rocha e a estética da fome. São Paulo: Duas Cidades; Editora 34, 2019, p.25-59. acentuado" in BASTIDE, op. cit. p.210.

115 RISÉRIO, op. cit, p.165.
} 


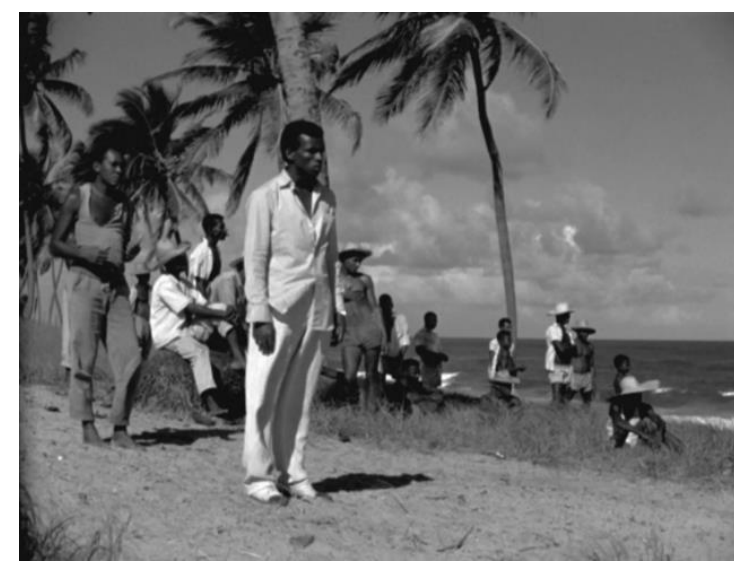

1 - esquerda da praia

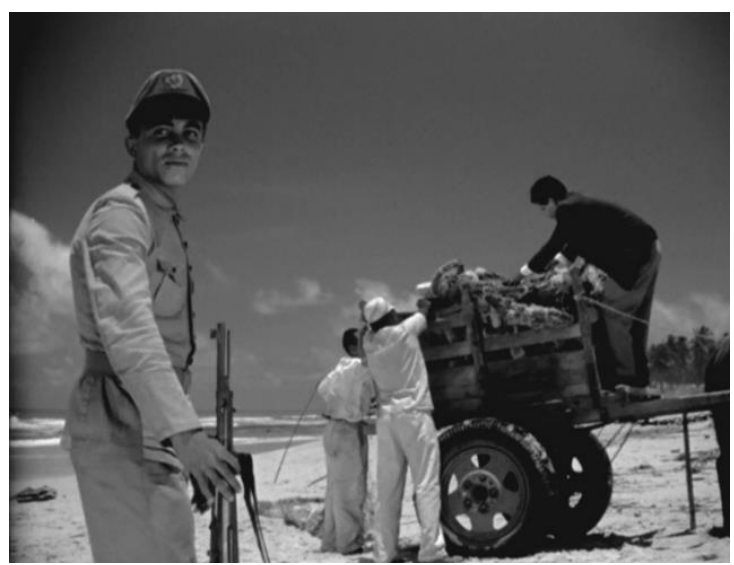

2 - direita da praia

$\mathrm{Na}$ análise anterior, do Mestre, procuramos demonstrar de que forma a sequência se constrói sob uma rígida dualidade espacial. Os campos (1) e (2) não se misturam, evidência da barreira que os divisa pelas relações de poder. À exceção de Firmino, as personagens quase não se movem, suas expressões gestuais são mínimas ou mecânicas: de um lado, assistir, segurar, silenciar; do outro, recolher, intimidar.

O malandro, que possui experiências de ambas as realidades, primeiro procura a comunicação, depois tenta forçar a passagem. Em contraste com a imobilidade geral, ele extrapola em dinamismo. Embora termine coibido em sua incitação, o tumulto faz o campo (2) perceber o campo (1), o que é em si mesmo um princípio de desestabilização das ordens. E mais, no curto período da confusão, Firmino convoca pelo menos dois símbolos fálicos: o gesto obsceno e a navalha, a última sendo mostrada em detalhe.

A profusão de energia e movimento em oposição às estruturas estanques do mundo e da sociedade faz pensar mais uma vez em Exu, esse mediador violento e subversivo, tanto quanto as alusões gestuais e discursivas ao falo, símbolo da força e da transformação ligadas a esse Orixá.

A sequência da recolha da rede é um exemplo entre outros tantos de como, ao longo da trama, Firmino está em constante relação com as zonas limítrofes. Nenhum outro personagem performa com tamanho dinamismo e plasticidade as transições entre espaços: ele salta e se equilibra em lugares difíceis como a pedreira do Farol e as jangadas na praia, escorrega, ginga, cai e se levanta no jogo da capoeira, abre e bate portas, no terreiro, na casa de Pai Tião, na casa de Seu Vicente, sobe dunas, desce barrancos, percorre, enfim, o dia e a noite. 


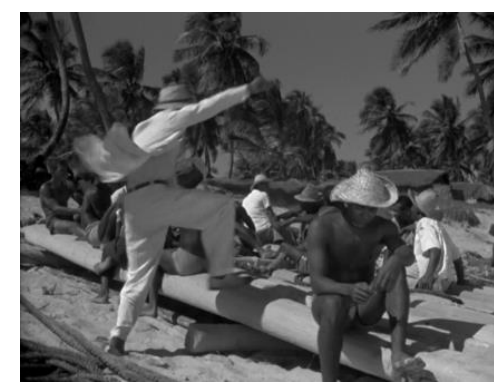

1 - Firmino salta e se equilibra por sobre a jangada na praia.

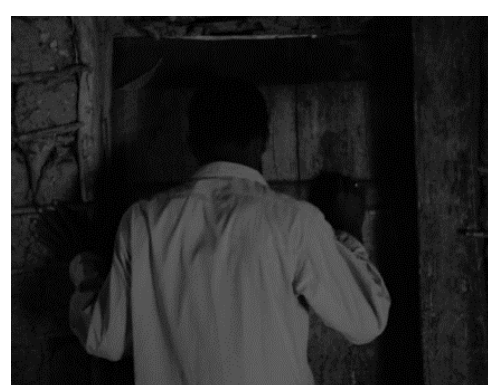

2 - Firmino bate à porta de Pai Tião.

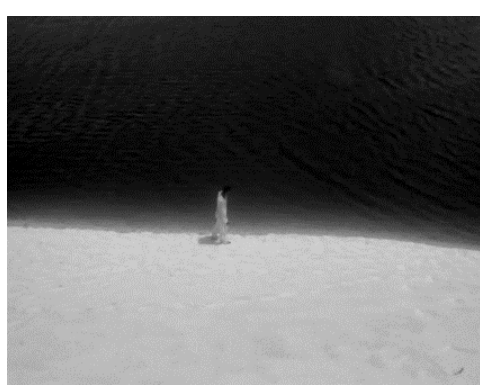

3 - Firmino percorre a zona limite entre a duna e a lagoa, contemplando o sítio da morte de Cota.

Por fim, há a trilha sonora. Temos procurado demonstrar como há uma escolha estética consciente de criar relações de sentido entre imagem, som e montagem. Aqui, a trilha sonora vem sedimentar a analogia Firmino-Exu. Quando o malandro entra no terreiro de Mãe Dadá demandando trabalho contra Aruan, sua voz está em off, ouvimos apenas a recusa da Ialorixá: "Não. Você não sabe que ele é protegido? Aqui não se faz nada contra gente de Iemanjá. Saia dessa casa, saia logo. Não!”. A conversa prossegue exaltada, agora toda em off, e vemos Mãe Dadá rechaçar Firmino, enquanto se escuta:

\author{
Laroyé! \\ Bará ô bêbê, Tirirí lónã \\ Êxú Tirirí \\ Bará ô bêbê, Tirirí lónã \\ Êxú Tirirí
}

Esse canto sagrado é um ponto de Exu. Ele é ouvido ainda em outro momento do filme. Quando, à noite, Cota se desnuda para ir ao encontro de Aruan na praia. Firmino atravessa correndo por entre os coqueiros para contemplar a consolidação do seu plano. De modo que o ponto emoldura a abertura e o fechamento da narrativa mística que corre em paralelo, centrada no malandro.

É o próprio Glauber Rocha quem termina por firmar a ponte entre a realidade histórica e o dado místico no malandro Firmino. A personagem se expande, para além dos limites de Barravento, para se tornar um símbolo da consciência de uma narrativa 
social, histórica e cultural da Bahia dos anos 1950-60: "O Pytanga que foge da polícia em Bahia [de Todos os Santos] reaparece na pele de Exu em Barravento."116

Assim, dentro da chamada trilogia da fome produzida pela "onda baiana do cinema”, entre 1958-1962 (A Grande feira, Bahia de Todos os Santos e Barravento), o interesse pelas urgências da reconfiguração urbana e das novas tensões sociais encontra no malandro Firmino uma espécie de síntese complexa: o discurso marxista da jovem intelectualidade se reapropria, no cinema, do substrato cultural da Bahia, reconfigurando as problemáticas do regionalismo que vinham desde os anos 1930 .

Barravento se distingue dos outros dois filmes por colocar o centro da ação na província, simulando a volta do indivíduo rebatizado pela nova metropolização urbana ao seu ponto de origem. Ao fazê-lo, está encenando a renovação de formas históricas de violência em ambos os espaços, capital e periferia provinciana.

Mas a análise de Firmino não se esgota nele mesmo. Isso porque a personagem se constrói em dualidade e convergência com seu oponente Aruan, que passamos a analisar a seguir.

\subsection{Aruan, a quebra do coité sagrado}

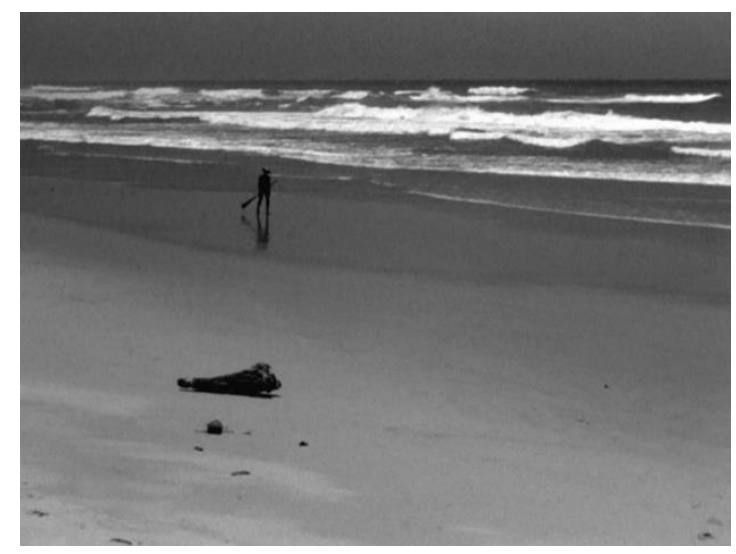

Quando eu venho de Aruanda eu venho só, só, só, eu venho só

Deixei lá pais, deixei lá avós, Só, só, eu venho só

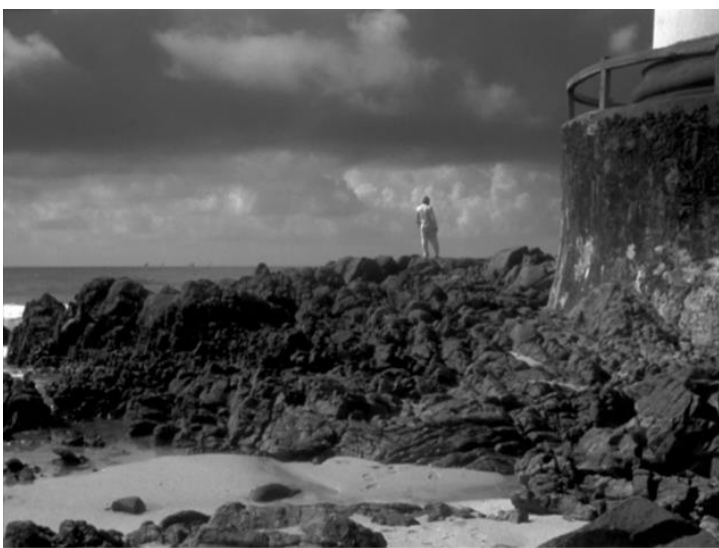

Óia tu que é moleque

Moleque é tu

Cala a boca moleque

Moleque é tu

116 ROCHA, Revolução do Cinema Novo, p.390. 
Vimos anteriormente como a sequência introdutória de Barravento salienta a oposição entre a individualidade de Firmino e a coletividade dos pescadores, mas a equação se complica ainda mais com a entrada em cena de Aruan. Vejamos a ordem dos planos:

I. Letreiro

II. Plano panorâmico de arrastão

III. Plano panorâmico de arrastão

IV. Chegada de Aruan

V. Chegada de Firmino

VI. Arrastão em primeiro plano: batuque

VII. Arrastão em primeiro plano: pernas (etc.)

A sequência se sucede de um tal modo que no miolo da alternância entre coletividade e individualidade se constitui uma oposição mais interna, e que pode passar despercebida. Aruan (Aldo Teixeira) e Firmino se refletem, com todas as inversões que o espelhamento implica, desde a estrutura dos seus planos inaugurais.

Aruan chega caminhando sozinho, em ritmo constante e retilíneo, pela esquerda do quadro. Sua indumentária simples evoca de imediato o universo ao qual pertence: chapéu de palha, torso nu, um remo na mão. O jovem pescador é emoldurado pela paisagem marinha: a praia e o céu. Um pequeno fragmento em primeiro plano (talvez um despojo de barco ou uma pedra) acentua a profundidade do quadro e, por conseguinte, a relação de harmonia entre o homem praieiro e a paisagem natural, não havendo preponderância de um sobre o outro. Sem interromper o ruído do mar, interno ao espaço diegético, a canção que acompanha Aruan vem ampliar o equilíbrio ambiental para uma ordem mística: "eu venho de Aruanda". É inclusive daí que provém o nome da personagem.

Assim como para Firmino, a toada foi cuidadosamente indicada no roteiro, embora a execução final da cena seja diferente do que fora previsto:

\section{CENA 2:}

\begin{tabular}{|l|l|l} 
41: & -Aruan puxando,canta,no meio & Aruan:Quando eu venho de aruan
\end{tabular}
do grupo. 
NOTA :

Planos : De 42 a 53, serão tomados como referência para montagem de puxada.Algumasreservas
Som:Canticos e gritos carac terísticos,referentes à ação.

Como se vê, pretendia-se originalmente que a canção traduzisse a voz de Aruan em meio ao grupo. A forma final revela a intenção evidente de isolá-lo junto ao seu fundo musical. Quanto à letra da toada, relembremos que Aruanda é o paraíso espiritual na vertente umbandística das religiões afro-brasileiras, trata-se de um espaço anímico habitado pelos encantados: pretos-velhos, caboclos etc. Embora transcendentes, esses espíritos diáfanos se relacionam com o plano terreno e as vontades humanas. Seria talvez o equivalente sincrético do Ayiê iorubano, o domínio dos Orixás, em oposição ao Orun, plano dos homens e seus destinos. ${ }^{117}$ Aruan surge, portanto, trazendo suas graças, como um emissário dessa esfera mística que vem se alinhar ao modo de vida e aos valores tradicionais da comunidade. Logo adiante o vemos, junto aos pescadores, perfeitamente integrado ao arrastão.

A entrada de Firmino é de um caráter diametralmente oposto. Ele vem da direita para a esquerda, salta por detrás do farol, que poderia ser entendido metaforicamente como a "desalienação e promessa de liberdade". ${ }^{118}$ Sua indumentária - aliás muito pouco apropriada para o ambiente praieiro e o trabalho braçal - assim como a altivez de "homem civilizado", "esclarecido", vão par e par com a representação de um indivíduo que traz o espírito secularizado da cidade e os novos modos de vida. Sua gestualidade, contudo, desmente a seriedade desse propósito. Conforme apresentamos anteriormente, ele é organicamente malandro, Zé Pilintra. Muito distinto do caminhar retilíneo de Aruan, vem gingando pela pedreira. Firmino não vem se agregar ao trabalho, mas convida os conterrâneos para a cachaça (por sua conta) e o samba.

O estribilho de capoeira que o acompanha, conforme dito, remete menos a uma proveniência espiritual do que ao conflito, o jogo e a provocação. Diferentemente do refrão de Aruan, que traduz a linearidade de uma narrativa mística em primeira pessoa, o refrão de Firmino não encena apenas a sua voz, mas também a de um outro que o

117 BENISTE, José. Òrun Àyié: o encontro de dois mundos: o sistema de relacionamento nagôyorubá entre o céu e a Terra. Rio de Janeiro: Bertrand Brasil, 1997.XAVIER, op. cit, p.57. 
repreende (“Óia tu que é moleque”, “moleque é tu!”, “cala a boca, moleque”, “moleque é tu”) - há um esboço de estrutura dramática, portanto.

Em suma, a construção desse espaço diegético introdutório sugere dois extremos: à esquerda Aruan, à direita Firmino, e no centro, no ponto de encontro entre as duas forças antagônicas, os aldeões e seu modo de vida tradicional. Mas a polaridade dos caracteres não se resume de forma tão simplista. Existem pontos de articulação e convergência entre Aruan e Firmino que vão se aprofundando no desenrolar da trama.

Visto mais de perto, o estribilho de Aruan revela um processo de individuação não menor do que o de Firmino. Há um subtexto trágico que se anuncia, o canto não fala de uma permanência no paraíso espiritual, mas de saída e abandono, um êxodo em alguma medida. "Deixei lá pais, deixei lá avós" fala do desenraizamento do indivíduo de seu solo natal. Esse mesmo estribilho, com ligeiras variantes, foi publicado em 18 de outubro de 1947 pelo jornalista Odorico Tavares em uma reportagem de teor etnológico escrita para a revista $O$ Cruzeiro, intitulada “A pesca do xaréu”. Em 1964, o artigo foi recolhido na coletânea Bahia: imagens da terra e do povo:

Os primeiros metros da corda da rede vão caindo na praia. Nas suas jangadas, os homens do mar fiscalizam, evitam qualquer imprevisto. $\mathrm{O}$ bailado da puxada prossegue na praia, sob o bater dos atabaques, sob o canto de vinte homens, trazendo para seu trabalho mais do que as cantigas porventura aliviadoras da tarefa, mas sobretudo os cantos de seus deuses e de seu passado:

Quando venho de Aruanda

Eu venho só

Coro:

Só só

Eu venho só.

Quando venho de Aruanda

Eu venho só

Eu deixei pai

Eu lá deixei vó.

Coro: 
Só só

Eu venho só.

Quando venho de Aruanda

Eu venho só

Eu lá deixei tia

Eu lá deixei vó.

E na canção vai todo o ritmo de ida e de volta da puxada da rede. Há uma atmosfera de nostalgia criada por esta canção tão bela na sua música, expressando na pobreza de suas palavras a grandeza da solidão. ${ }^{119}$

A reportagem de Odorico Tavares revela que o estribilho de Aruan é, na verdade, um canto de arrastão. Originalmente, ele previa uma toada seguida de uma resposta coletiva, distinta da versão solo que acompanha a entrada do jovem pescador em Barravento. Há um viés eminentemente romântico no lirismo com que o jornalista concatena as ideias de trabalho, pobreza material, simplicidade do canto, nostalgia e solidão. Ao mesmo tempo, contudo, ele salienta a maneira com que o aspecto cíclico do trabalho da puxada se reproduz no canto, talvez uma referência ao paralelismo dos sintagmas venho só - deixei lá, que desenham movimentos inversos e configuram dois espaços distintos: o lado de cá é o lado da solidão, do presente; o lado de lá, da coletividade familiar, dos ancestrais do passado.

Pode-se dizer então que há, ao menos a princípio, um conflito entre o que a montagem nos mostra - a ida de Aruan em direção à coletividade - e o sentido da canção - o abandono da coletividade em direção à solidão. Abre-se um espaço dialético que retoma a ideia de atrito entre os elementos compositivos da trama, no caso, som e imagem.

A partir daí, duas hipóteses podem ser levantadas: seguindo a linha interpretativa esboçada por Odorico Tavares, admitimos que o canto ecoa um passado histórico-mítico: o estribilho representa o banzo do homem negro escravizado que deixou além-mar o paraíso original da sua espiritualidade e a companhia dos ancestrais em direção à solidão secular do Ocidente, onde se torna um ser individualizado e solitário.

119 TAVARES, Odorico. Bahia: imagens da terra e do povo. 2 ed. Salvador, J. Olympio, 1964. p.73-74. 
Algumas passagens do filme alimentam esse subtexto. Observe-se o fotograma a seguir:

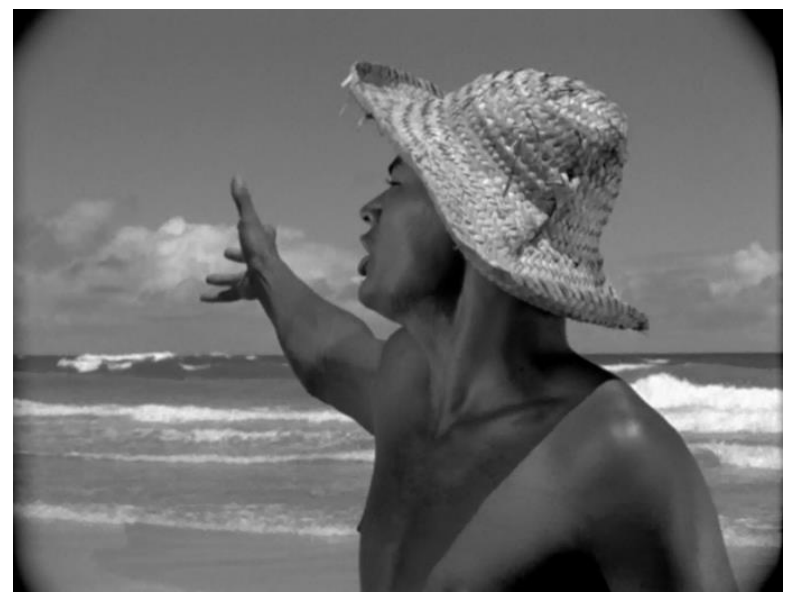

Nessa cena, Aruan, exaltado com a passividade dos seus conterrâneos quando a carroça vem recolher as redes, aponta para o mar em um gesto proeminente e diz: "Nós temos que reagir. Viemos de lá escravos, mas a escravidão já acabou." O lá do seu discurso, ilustrado pelo gesto, refere-se de maneira elíptica à África e ao passado colonial em detrimento da possibilidade de ação sobre o presente. Em outro passo, é Firmino quem faz uma alusão semelhante, ainda mais explícita: "Eu, pescador? Isso é vida de índio. Isso aqui não é África, é Brasil.” Novamente o jogo entre dêiticos aqui e lá, correspondentes a Brasil e África, enfatizando dessa vez o lugar da enunciação.

Assim, alinhando-se ao "programa" do filme, o espaço mítico de Aruanda, historicamente correspondente à África, torna-se um lugar psíquico de apego à ancestralidade, à tradição e a uma mazela histórica que precisa ser conscientemente superada para o nascimento de uma subjetividade crítica, madura. O tom "nostálgico" do estribilho de Aruanda ganha então uma conotação histórico-política.

Uma segunda hipótese, não totalmente desconectada da primeira, liga o canto de Aruanda à evolução do enredo de Barravento. O estribilho e a entrada solitária de Aruan já anunciam em si a convergência entre o seu destino e o de Firmino, isto é, o êxodo em direção à cidade, deixando na terra natal a infância ingênua das crenças originais e da família.

Dessa forma, a trama de Barravento se constrói, no que diz respeito a Aruan, em torno de uma linha ascendente de maturidade pontuada por três momentos: a infância provinciana; a puberdade das ideias e a perda da virgindade; a partida para a vida adulta na cidade. Barravento se converte no rito de passagem de Aruan, desencadeado pela 
experiência do sexo que destrói a sacralidade da infância. A sexualidade como cumprimento da maturidade e emancipação do homem do mar não é um tema indiferente à Literatura, especialmente à matriz praieira do regionalismo, cujo imaginário poético ecoa no filme de Glauber Rocha.

A título de exemplo, há uma série de paralelismos entre Aruan e Guma, protagonista do romance Mar morto, de Jorge Amado. Ambos pescadores de uma habilidade precoce, órfãos, cumprem um papel de liderança carismática dentro de suas respectivas comunidades. Adotados por pescadores mais velhos, mestres conhecedores da tradição e do passado, os dois jovens ignoram a integralidade de sua própria história. Tanto o Mestre quanto o velho Francisco, como detentores desse passado identitário de seus aprendizes, gerenciam os seus destinos na reverência a Iemanjá.

No plano amoroso, Lívia, amante de Guma, em um momento de introspecção, extravasa seus ciúmes pelo destino trágico do homem do mar, fillho e esposo de Iemanjá, cujo destino é incontornavelmente selado no dia em que a Orixá decide trazê-lo para o seu seio e consumar o amor incestuoso, afogando-o nas tempestades.

Já em Barravento, Naína é repreendida ao manifestar seus sentimentos pelo jovem sagrado, preferido de Iemanjá:

Dona Zezé: Joaquim era um homem muito bonito demais, por isso Iemanjá não queria que ele se casasse. A gente fala pra proteger Aruan, não fala? Não viu que por causa dele agora o povo tá todo indo pescar sem rede, minha filha? Por isso então agora a gente tem que guardar Aruan.

Naína: Então ele nunca vai ter mulher?

Dona Zezé: Só no dia que tiver outro da idade dele. Não tá vendo o Mestre? Até hoje vive sozinho. Amizade ele só tem com Aruan. A Rainha tem ciúme de homem bonito.

Naína: Mas eu estou gostando dele. Se pai morrer eu me acabo sozinha. Dona Zezé: Cala a boca, menina danada! Vai ver Mãe Dadá hoje de noite!

A natureza incestuosa da relação de Iemanjá com seus filhos é amplamente representada em sua mitologia: em um dos itans (contos), Iemanjá dá à luz o panteão das divindades após ter sito violada pelo seu próprio filho, Orungã. Em outro, Iemanjá seduz deliberadamente seu filho, o jovem Xangô, e apesar da resistência inicial, não desiste até 
consumar a profanação. ${ }^{120} \mathrm{O}$ erotismo incestuoso de Iemanjá é ilustrado no enredo de Mar morto pelo encontro de Guma com sua mãe. Antes de ser apresentado a uma estranha que vem à residência acompanhada por seu tio, Guma imagina tratar-se de uma prostituta trazida para sua iniciação sexual e a deseja carnalmente, até que descobre tratar-se de sua mãe. Após o encontro, reflete:

Nunca mais sua mãe voltou. [...] Por muito tempo, porém, a sua imagem, o seu perfume, perturbaram o sono tranquilo de Guma. Desejava que ela voltasse, mas não como sua mãe, não com palavras doces de afeto, mas como uma mulher da vida, com os lábios abertos para beijos de amor. Não teve mais sossego. Misturou no seu coração tão jovem a imagem daquilo que todos achavam a própria pureza, a imagem da mãe com a das mulheres que se entregam por dinheiro, das que fazem do amor o seu ofício. Mas nunca tivera mãe, quando a encontrara foi para a perder logo, para a desejar sem querer, para quase a odiar. Só há uma mãe que pode ser ao mesmo tempo esposa: é Iemanjá, e por isso ela é tão amada dos homens do cais. Para amar Iemanjá que é mãe e esposa, é preciso morrer. Muitas vezes Guma pensou em se atirar do alto do saveiro num dia de tempestade. Viajaria então com Janaína, amaria a mãe e esposa. ${ }^{121}$

Dois anos depois do encontro com a mãe, Guma consuma enfim uma relação sexual, após o quê desaba uma tempestade, entendida por ele como a fúria ciumenta da Orixá. Dali em diante, o jovem tem autonomia não apenas sobre seu corpo mas sobre seus meios de trabalho, pois passa a poder conduzir sozinho o saveiro. Aruan padece de um preceito semelhante, com a diferença fundamental de viver uma infância prolongada. Guma, por ser um entre tantos prediletos de Iemanjá no cais da Bahia, pode se permitir a aventura carnal contanto que não sobrepuje a reverência à divindade: por isso rompe sua castidade aos 14 anos completando assim o ciclo da meninice para a vida adulta, o sexo se fazendo sempre muito presente desde então.

\footnotetext{
120 PRANDI, op. cit., p.382-383 e p.395-396.

121 AMADO, Jorge. Mar morto. Rio de Janeiro: Record, 63 ${ }^{\mathrm{a}}$ ed., 1990, p.27-28.
} 
O jugo sobre Aruan é muito mais rigoroso: sendo o jovem sagrado do pequeno vilarejo, a ruptura ou conservação de sua virgindade (o coité, ${ }^{122}$ nas palavras de Firmino) não estão ligados apenas à livre expressão de seu desejo ou imposição de sua virilidade madura diante do grupo. Sua virgindade é o fundamento da crença espiritual em torno da qual a comunidade orbita, e o preço a pagar pelo equilíbrio cósmico. A castidade de Aruan é a expiação dos aldeães junto a Iemanjá, a garantia da pesca venturosa uma espécie de termômetro das tensões entre o transcorrer da vida no plano terreno e os humores do plano divino.

Por outro lado, a perpetuação de sua infância também está ligada a lacunas de identidade, ocupadas pela repressão hierárquica de um duplo poder, interno e externo à comunidade (Mestre-Dono das redes). A mãe e o pai carnais de Aruan são incógnitas, tudo o que sabemos de sua ancestralidade, que não seja a alusão do canto de entrada, é retido pelo Mestre como um mecanismo de manipulação sobre o destino do jovem. Observem-se os dois fotogramas abaixo:

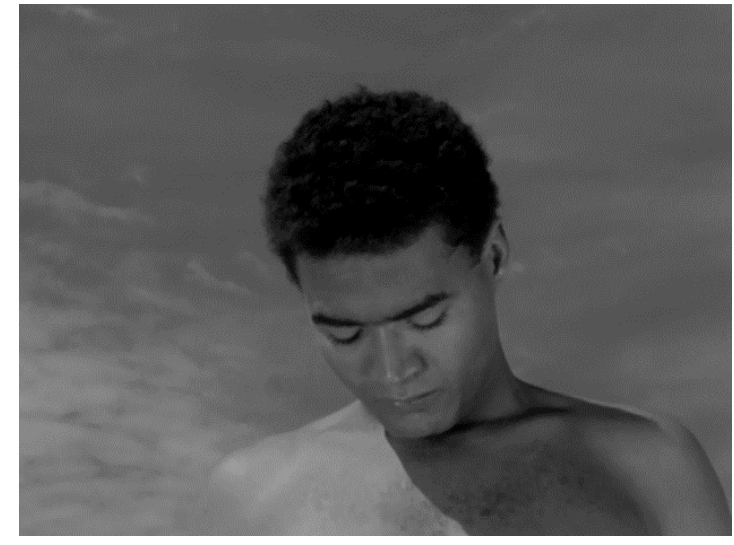

1 - "Bem, o que eu falei foi pra valer. Se não der peixe o homem vem buscar a rede e vocês que se acabem."

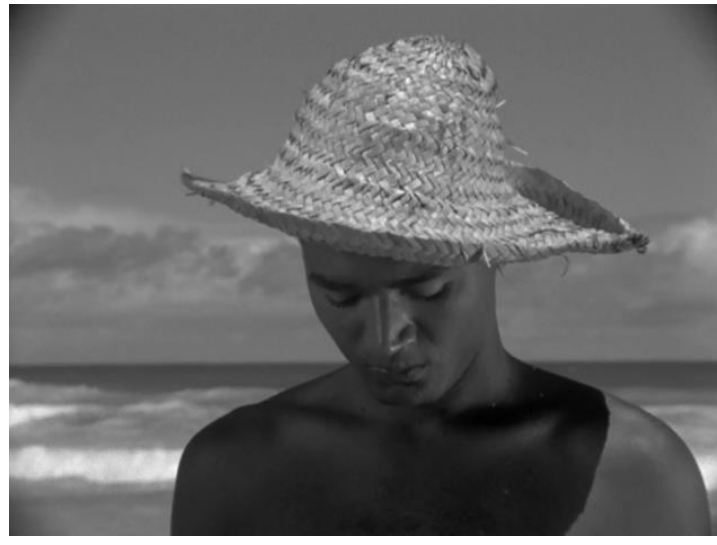

2 - "Ninguém se mexe, a lei tá com eles."

São quadros gêmeos que representam, em momentos distintos da trama, a força constritora do poder econômico, mediado pelo Mestre - neles, a câmera busca a expressão

\footnotetext{
122 O coité é, na verdade, um tipo de recipiente utilizado na ritualística do candomblé e da umbanda para a ingestão de bebidas pelas entidades e divindades. Portanto, uma cabaça sagrada. Firmino refere-se ao coité como vínculo de Aruan ao sagrado, portanto, sua virgindade. É curioso notar como, na linguagem coloquial, "cabaça" ou "cabaço" é um termo usado como sinônimo de virgindade.
} 
de subserviência melancólica encenada por Aldo Teixeira. No primeiro, vê-se a derrota de Aruan após reagir violentamente ao mandatário do dono da rede, que ameaça recolhêla. No plano imediatamente anterior o mandatário tinha reafirmado sua intimidação e o jovem recua, baixando a cabeça. O Mestre vem restabelecer sua força de trabalho: "Fique triste não, a gente remenda a rede". Ao que Aruan responde: "É Mestre, eu faço. Faço o que o senhor quiser. Mas se fosse eu resolvia no peito." Isto é, o aprendiz submete sua vontade de mudança e se coloca como uma força a serviço das ordens estabelecidas.

No segundo momento, a ameaça de recolha da rede se efetiva, mas as fissuras dessa instância de autoridade já estão mais evidentes pelo acirramento da violência. $\mathrm{O}$ tom de Aruan sobe, e ele profere "o discurso da escravidão" citado mais acima, ao que o Mestre responde: "Direito de pobre é trabalho. Com a jangada se pesca menos, é mais arriscado, mas o peixe é nosso. Tem de ser assim até o fim.” Em silêncio, Aruan volta a baixar a cabeça, mas já não exprime verbalmente subserviência àquelas leis de exploração perpétua.

O espectador e Aruan caminham juntos no desvelamento gradual de seu passado, na medida em que se esmaece a aura sagrada que o envolve e a arbitrariedade dos preceitos do Mestre. Há uma faceta trágica edipiana do jovem pescador: o caráter incestuoso da teia que envolve sua sexualidade truncada na relação com o sagrado (a mãe e esposa Iemanjá), e o estar preso a uma ordem cíclica de acontecimentos que escapa à sua compreensão: o amor proibido de Joaquim e Isabel se repete nele sem que se dê conta. Como consequência, a recuperação gradativa de sua identidade leva à catástrofe que custa a morte de Chico, Seu Vicente e Cota, e enfim, o expurgo, o exílio - ou, nesse caso, o êxodo.

O momento decisivo dessa anagnorisis é a conversa com seu camarada de pesca, João, quando a rede das tramoias de Firmino está chegando ao limite da irreversibilidade:

Aruan: $\mathrm{O}$ que é que nós vamos fazer, João. O Mestre parece que não entende. Jogou o povo no fogo. Ninguém tem raça de se meter no mar em cima duma jangada dessa. Vou eu, você, o Chico, a turma boa. E os velho? Vai tudo morrer afogado.

João: É... o diabo é que o Mestre quer ver se você tem raça mesmo. O negócio da coragem dos outro depende da sua.

Aruan: Mas por quê? Não sou o pai do mundo, não. 
João: Quer saber de uma coisa? O velho the trouxe da cidade, lhe criou. O velho não teve filho, sempre com medo de casar. Você ficou sendo dele e do Santo. Quando você virou homem, ele começou a falar umas coisa maluca. "Aruan não pode casar, Aruan é filho de Iemanjá”. Tudo quanto foi mulher deu pra correr. Convenceu a gente de que você podia sair de jangada e apanhar peixe no fundo do mar. Agora que estamos sem rede ele quer provar a verdade. Por isso deixou a rede ir.

Aruan: Quer dizer que tenho que me arriscar na frente? Quer dizer que não vamo cuidar da rede nova?

João: É isso mesmo. Pra sair dessa história você tem que ir e passar a noite no mar. Aí todo mundo acredita que Janaína tá calma. O negócio tá nas tuas costas.

Aruan: Mas eu não sou Santo. E se barravento bater e eu me estragar? João: É preciso ver se você é protegido mesmo. Mano, até eu acredito. Depois, depois a coisa pode melhorar pra melhor. Não é isso que nós queremos? Até Firmino tem razão, é muita miséria.

Aruan: $\mathrm{O}$ caso é resolver a pescaria. Tenho de ir logo, passar a noite fora. Você avisa o mestre e amanhã todo mundo sai. Eu trago o peixe, depois vou-me embora de vez. Um dia posso voltar como Firmino e mudar tudo. Só preciso coragem, coragem aqui na cabeça.

No trecho acima, não apenas Aruan compreende o peso dos fundamentos que o aprisionam às convicções do Mestre e a vontade arbitrária de pô-lo à prova diante da comunidade, mas surge uma informação importante sobre a história de sua vida que acarreta uma problemática relativa ao seu pertencimento: Aruan não nasceu no vilarejo, ele é da cidade. Sua casca de jovem da província, filho de todos e do Santo, esconde, na verdade, um homem urbano órfão. Agora desenraizado do solo familiar praieiro, daí por diante, seu caminho está praticamente pavimentado para cumprir um novo papel, à semelhança de Firmino: o de lumpem no anonimato urbano.

A convergência entre os caminhos de Aruan e Firmino é tamanha a essa altura que o roteiro de Glauber previa uma interpolação no trecho acima transcrito, que não foi incluída no filme:

João: [...] Até Firmino tem razão, é muita miséria.

Aruan: Firmino... Firmino... Não deixei ele espantar os soldados só pra respeitar o Mestre... Bem que tava com vontade de dar uma carreira 
naqueles brancos... Firmino queria era mostrar nossa força... Mas a gente só presta é pra mergulhar, puxar rede... Aí tem coragem de sobra... Pra defender a barriga somos tudo frouxo feito cachorro sem dono... Firmino é independente, faz o quer e tem Cota na hora que bem entende....

Nessa variante do diálogo, Aruan pareceria vislumbrar uma coletividade com potencial transformador nos termos "nossa força" em oposição a "aqueles brancos", expressando uma percepção do conflito social que parece ter assimilado a experiência urbana marginalizada de Firmino. É o reforço de uma adesão que já tinha dado sinais em outro diálogo, esse sim incluído no filme:

Aruan - se eu fosse o Mestre já tinha parado de puxar até que dessem um jeito. Acho que esse negócio de puxar pros outros é papel de besta. Chico - Tá querendo demais, Aruan. Aqui a gente vive melhor que na cidade. Tá indo na conversa de Firmino?

Aruan - Firmino não vale nada mas pelos menos num pede esmola. João - quem nasce pobre morre comendo areia. Essas coisas eu deixo pro Mestre resolvê.

Há uma forte ressonância da fala "mas pelo menos não pede esmola" no canto final de Aruan (mencionado na análise anterior), quando a toada evoca "se o dinheiro não corre, de fome ninguém não morre.” A concepção idealizada da cidade como espaço de superação da miséria da província que acompanha Firmino, liga o fim ao começo do filme por meio de Aruan. É ele quem melhor assimila o discurso do malandro porque já tem na raiz de sua identidade fragmentária o germe da dupla-marginalização da qual Firmino padece, o não pertencer integralmente a nenhum espaço. Isso também está posto nas suas transições morais.

Por exemplo, observe-se que o termo “coragem” é pelo menos duas vezes reiterado nos excertos de diálogo citados mais acima para explicitar a contradição da atitude dos aldeões: por um lado, a capacidade do feito heroico no enfrentamento com o mar, espaço mítico do imaginário coletivo, por outro, a falta dela diante da opressão histórica. A câmera procura imprimir em Aruan essas duas dimensões: 


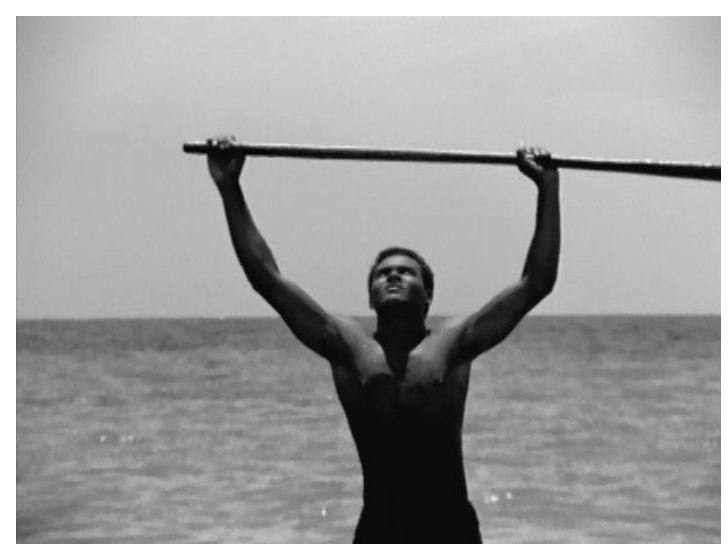

1 - Aruan volta após o enfrentamento do mar. Ouve-se o ponto de Iemanjá.

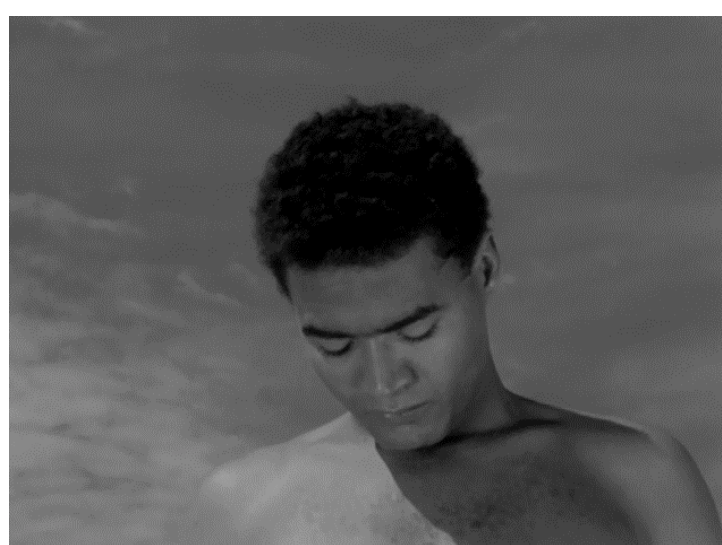

2 - Aruan submisso no enfrentamento do mandatário do dono das redes.

No primeiro quadro vê-se o homem transfigurado em ser mítico, a câmera o suspende em uma espécie de plenitude cósmica com a natureza após o feito épico. No segundo a submissão de que tratamos anteriormente; mais dramático, o plano capta a solidão e impotência do indivíduo ante as forças do mundo material. A transição já tinha sido apontada por Glauber Rocha:

Primeira tempestade e Aruan enfrenta mar violento na jangada, vence o mar, se iguala a Ulisses, todos pescam, vem peixe. Firmino precisa destruir aquilo, pois não pode admitir aquele sacrifício. Ele também é um fanático, mas tem um horizonte de liberdade. ${ }^{123}$

De qualquer forma, a interpolação foi suprimida, nesse movimento que parece ser comum à reelaboração do roteiro: a escolha da maneira mais elíptica de insinuar as tensões entre os mundos em choque - a narrativa mítica e o drama histórico - buscando resoluções na montagem. O fato é que a eclosão dessa análise crítica no discurso de Aruan extrapola o cerco da narrativa trágica para aludir a uma circunstância social. O jovem passa a reverberar uma consciência política, tornando-se ele mesmo essa espécie de personagem brechtiana dialética.

Aquela "coragem aqui na cabeça" de que fala Aruan se manifesta no plano corpóreo e simbólico pela necessidade de ruptura com a castração de Iemanjá, cujo amor incestuoso só se efetua na morte. O sexo carnal e dessacralizado aparece, por conseguinte,

123 ROCHA, Glauber. Cartas ao mundo (org. Ivana Bentes). São Paulo: Companhia das Letras, 1997, p.127. 
como uma pulsão de vida que combina com a nova consciência de Aruan. A premência do sexo é mais explícita na fala "Firmino tem Cota na hora que quer", onde o jovem deixa entender alguma inveja da liberdade sexual do malandro, paralela à liberdade de ação, de ideias. O domínio sobre o próprio corpo e o nascimento da individualidade pelo autoconhecimento requerem a morte do corpo espiritual e culminam no isolamento e no êxodo, como uma necessidade de novas formas de socialização - urbanas.

Por fim, em uma perspectiva mais ampla, e retomando a ambiguidade da "canção de Aruanda", poderíamos dizer que Aruan é um indivíduo que se "metropoliza" e "marginaliza" pela perda do horizonte do sagrado, substituindo um mecanismo de opressão e subserviência no modelo de sociedade provinciano por outro, na capital: a ilusão da transcendência pela ilusão da aquisição de bens.

A interpretação do percurso psicológico e social de Aruan nos conduz a outra personagem que também está sob a regência imediata do sagrado, mas em um caminho inverso, da incredulidade para a sacralização: Naína.

\subsection{Naína e a melancolia dos mestiços}

Naína (Lucy de Carvalho) é uma personagem marcada por um estado permanente de melancolia e inquietação, em princípio devido à preocupação com seu pai, Seu Vicente, um velho homem do mar. À medida que a trama se desenrola, contudo, percebemos que as raízes desse temperamento estão ligadas a uma problemática mais profunda: a do despertencimento.

Aliás, em maior ou menor grau, todas as personagens centrais de Barravento, à exceção talvez do Mestre, experienciam em algum nível o despertencimento como afastamento da órbita da vida tradicional na comunidade. $\mathrm{O}$ enredo do filme encena a evolução desse movimento de exclusão em cada uma delas e como o agenciam, seja no sentido de uma ruptura irreversível, seja pela inclusão definitiva no sistema de valores local.

Conforme vimos anteriormente, Firmino experiencia a marginalização nos dois âmbitos espaciais da sua vida, cidade e vilarejo, e termina por desaparecer após o cumprimento de sua missão. Aruan, a princípio filho de todos e do Santo, descobre-se um órfão "sequestrado" à capital - e vai trilhar o caminho aberto do êxodo, por fim, esperançoso de encontrar meios de subsistência na cidade. Cota, por sua vez, vive à margem do código de moralidade local e da subserviência das mulheres praieiras, e não 
está subjugada pelas mesmas leis de exploração dos homens da pesca, o que trataremos na análise seguinte. Ela é cúmplice de Firmino e paga com a morte pelo desrespeito às leis cósmicas do Orixá. Dentre eles, Naína é a única que cumpre o destino contrário, mulher branca em uma comunidade negra, filha de uma relação ilegítima, ela reluta em assimilar os fundamentos religiosos, mas termina por fazer o Santo e incorporar a sacralidade. Assim, se todos seguem o rumo da exclusão, ela, por sua vez, é incluída.

Muito do que se pode intuir sobre a construção dessa personagem provém do estudo do roteiro original, isso porque no filme há uma atrofia de muitas de suas interações, algumas delas resolvidas por Glauber Rocha (e Nelson Pereira dos Santos) através de expedientes da montagem, fórmulas menos discursivas, como demonstraremos. Basta dizer que na primeira versão do roteiro, Firmino não saía vitorioso do último jogo de capoeira e era expurgado do vilarejo acompanhado por "sons infernais, sugerindo as profundezas do inferno". Em seguida Aruan e Naína se encontravam na praia para consolidar sua união.

Nessa versão, a recusa da religião por Naína tem um papel muito mais explícito no desencadeamento do barravento, tanto quanto a profanação de Aruan. Seus descasos com a lei divina são a dupla causa da fúria de Iemanjá. Em uma fala não incluída, Cota chega a insinuar que os acontecimentos agourentos se deviam à recusa da jovem em fazer o Santo: “Agora fica Naína, só porque tem cabelo bom e pele clara criando caso pra não intrá na camarinha." (Sequência 38, planos 344-348). Em outro passo, a acusação final de Firmino se dirige também à jovem: “a culpa é dela que renegou o santo!” (Sequência 63a, planos 607-625)

Prova dessa função diferenciada de Naína é a forma como se daria o desenlace da narrativa:

\section{SEQUÊNCIA 73 EXTERIOR/DIA/PRAIA}

P.75

\begin{tabular}{|c|l|l|}
\hline $763-$ & As jangadas voltando do mar & $\begin{array}{l}\text { Música épica de alegria e en } \\
\text { tusiasmo.Explosão }\end{array}$ \\
\hline $764-$ & Rosa abre os olhos aliviada & Choro de criança.Música \\
\hline $765-$ & Naína solta um riso feliz & Música \\
\hline $766-$ & $\begin{array}{l}\text { Os pescadores se aproximam } \\
\text { Na jangada grande João, e }\end{array}$ & Voz:O filho de Chico nasceu \\
\hline
\end{tabular}




\begin{tabular}{|c|c|c|}
\hline & $\begin{array}{l}\text { Aruan, }{ }^{\mathrm{e}} \text { Mestre ouvem um grito } \\
\text { de mulher vindo da praia }\end{array}$ & \\
\hline $767-$ & Aruan ouve, está feliz & Música \\
\hline $768-$ & $\begin{array}{l}\text { As jangadas na praia.Todos } \\
\text { saltam felizes.Correm para a bar } \\
\text { raca grande;Aruan fica atrás,olha }\end{array}$ & Idem \\
\hline 769- & $\begin{array}{l}\text { Naína anda feliz pela praia } \\
\text { Seu rosto reflete que ela } \\
\text { quer ser como as outras.Naí } \\
\text { na anda na praia.Aruan ao fun } \\
\text { do olha.Depois Naína começa a } \\
\text { correr em direção aos coqueiros }\end{array}$ & Idem música,cessa \\
\hline $770-$ & Aruan dispara correndo e grita & $\begin{array}{l}\text { Aruan:Naína não precisaa você } \\
\text { ir embora }\end{array}$ \\
\hline
\end{tabular}

Nas sequências anteriores ao trecho acima, Rosa, a esposa de João, entra em trabalho de parto, mas o bebê está atravessado, causando complicações e dores atrozes. Mãe Dadá diz que, apesar de ter sido servida pelo corpo de seu marido, Iemanjá seguia enfurecida. Aqui vemos a conclusão de uma sequência alternada em que as Filhas de Santo cortam os cabelos de Naína e os lançam ao mar, fazendo com que, enfim, o parto de Rosa se conclua, dando à luz o sucessor de Aruan. O equilíbrio só é reestabelecido após a comunhão espiritual de Naína com Iemanjá.

Poderíamos sintetizar da seguinte forma: o casal Naína-Aruan engendra profanações contra o sagrado, em parte estimuladas por Firmino. Cabe a Naína reatar os laços rompidos com o Orixá para viabilizar ao mesmo tempo a reabilitação de Aruan junto à comunidade e o nascimento de seu sucessor. A "humanização" de Aruan permite a realização amorosa dos dois jovens, já que a quebra do coité será expiada na camarinha, onde Naína estabelecerá um fundamento com Iemanjá. Ao fazê-lo, torna-se parte da divindade, segundo os ritos litúrgicos. ${ }^{124}$ De certa forma, a conjunção com o sagrado é intrínseca à personagem, tendo em vista que o nome Naína é a contração de "Janaína", uma das diversas denominações de Iemanjá. Assim, Aruan teria substituído a relação direta com a Iemanjá puramente divina por uma versão carnal do Orixá, devidamente

$124 \quad$ BASTIDE, op. cit. 
consagrada. A troca eficiente reestabelece a ordem entre as forças cósmicas (Orun) e o plano terreno (Ayiê).

Naturalmente que, ao dar ênfase a Firmino agregando elementos ideológicos e críticos ao seu discurso, Glauber Rocha altera o funcionamento interno do enredo, reduzindo a preponderância da narrativa romântica do par Aruan-Naína. A personagem Rosa, por sua vez, com toda a problemática da gravidez atrelada ao sagrado, fica completamente ofuscada. No fim da primeira versão, Aruan diz a Naína que a jovem "já não precisava ir embora". Ao chamá-la de volta à órbita da vida provinciana, o seu discurso dá centralidade à assimilação de Naína pelo grupo, ao passo que o núcleo da ação, fica sendo a disputa entre o malandro e o jovem provinciano, que culmina na secularização e êxodo do último. Afinal, que posição Naína passa a ocupar dentro do novo arranjo da narrativa?

Para responder a essa pergunta, observemos o processo de síntese das suas relações e tensões em meio aos acontecimentos. O diálogo de entrada da personagem, por exemplo, anuncia o encaminhamento de seu drama pessoal no espectro da comunidade:

Chico: Naína, o peixe de Seu Vicente tá separado lá pra você levar. Que tristeza é essa?

Naína: Essa mania de pai ir pro mar, agora.

Aruan: Mas é que o velho tem o mar no sangue. Não se importa com isso. É capaz até de ser bom pra ele.

Naína: Mas ele tá velho pra ir pro mar sozinho.

Chico: Não pensa mais nisso. De hoje em diante eu tomo conta dele.

Naína se afasta lentamente.

João: A menina tá dando pena. É dia e ano nessa aflição.

Chico: É tudo por causa da cor dos olhos e do cabelo. Essa gente fica é inventando coisa.

Aruan: Na minha frente é que ninguém bole...

João: Vocês querem saber de uma coisa? O negócio é um homem de coragem pegar a moça, casar e pronto.

A câmera mostra Aruan.

Nesse diálogo estão colocados dois nós relativos ao papel de Naína: a questão da paternidade ("essa mania de pai ir pro mar") e a questão racial ("é tudo por causa da cor dos olhos e do cabelo"). 
A relação com o pai aparece como a causa primeira do abatimento da jovem, embora seja curioso notar a quase total ausência de Seu Vicente no filme. Ele faz duas aparições, tardias e muito efêmeras, se apresentando como uma figura cega, errante, silenciosa, que não toma parte na vida comunitária. A primeira aparição é um face a face totalmente silencioso com Naína. Na segunda, atende ao chamado de Firmino, que o conduzirá para a morte, ou melhor, o desaparecimento misterioso "dentro de uma nuvem", nas palavras de Aruan.

Por serem escassas, as aparições de Seu Vicente se tornam tão mais reveladoras de sentidos. Sua única interação com Naína é encenada pouco depois do bloco em que os círculos de homens e mulheres evocam a memória comum do vilarejo. Relembram-se efeitos passados do barravento, a miséria e a relação proscrita entre um antigo protegido de Iemanjá, Joaquim, e Isabel, mulher de má fama. A partir do momento em que Aruan decide ir para o mar, constrói-se um lapso de tempo envolto em um clima crescente de misticismo. Ele é preenchido por planos extremamente fragmentários: Mãe Dadá entoa o ponto de Iemanjá, diversos pescadores se lançam ao mar em jangadas ao som de cantos de arrastão, Firmino ronda, as mulheres esperam na praia, etc.

É nesse ínterim que Naína vem ter com seu pai:
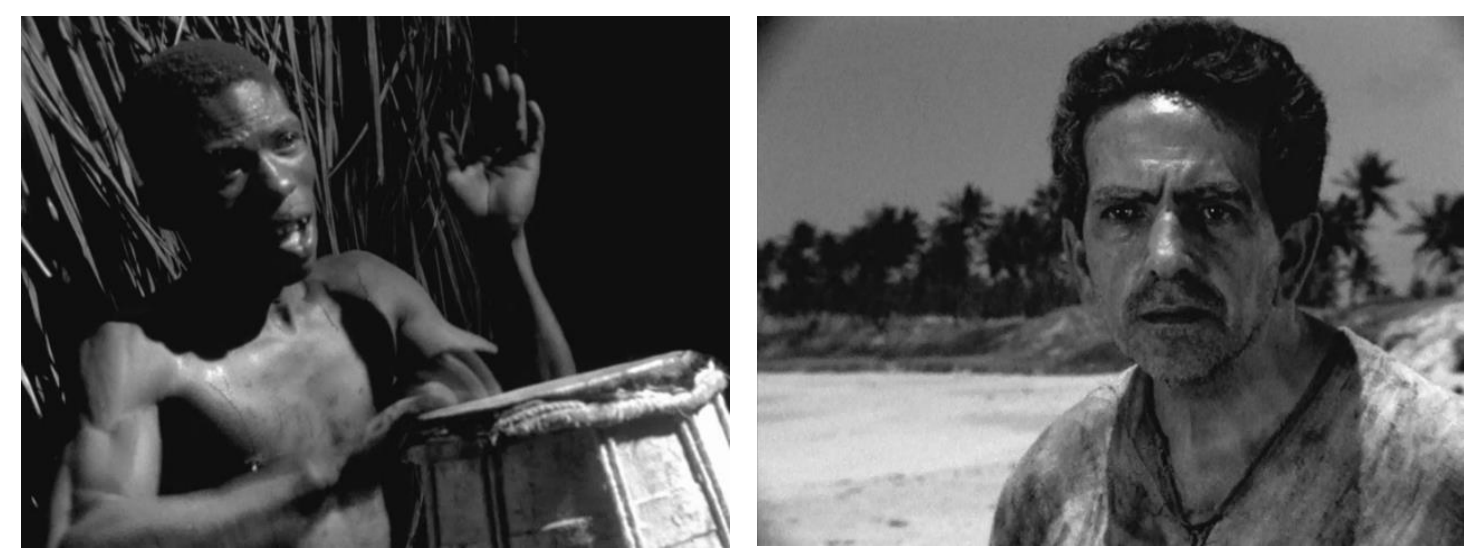

1 - Ogã toca o atabaque.

2 - Naína : "Pai você vai pro mar outra vez?" 


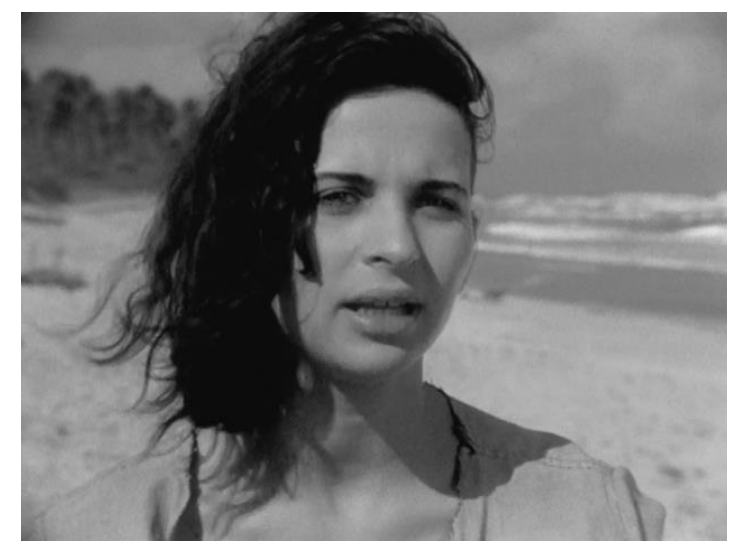

3 - "Iemanjá existe mesmo? Mãe Dadá diz que eu sou filha dela? Será que até eu com essa cor?"

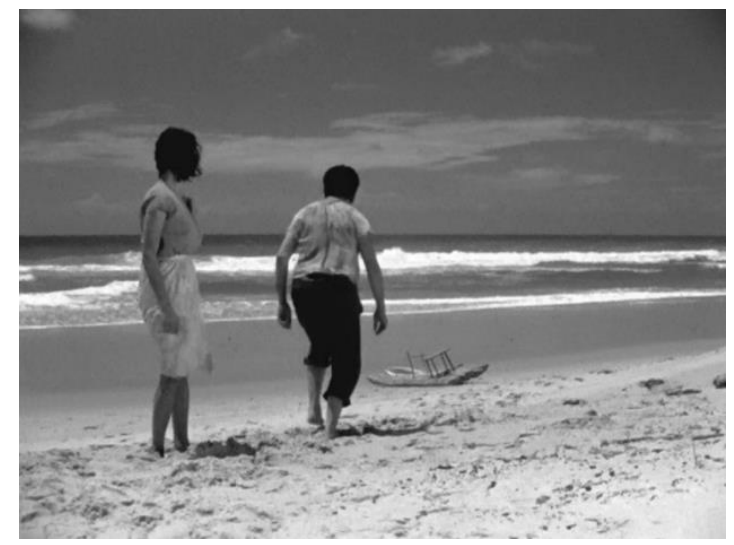

5 - Em silêncio o velho se dirige ao mar.

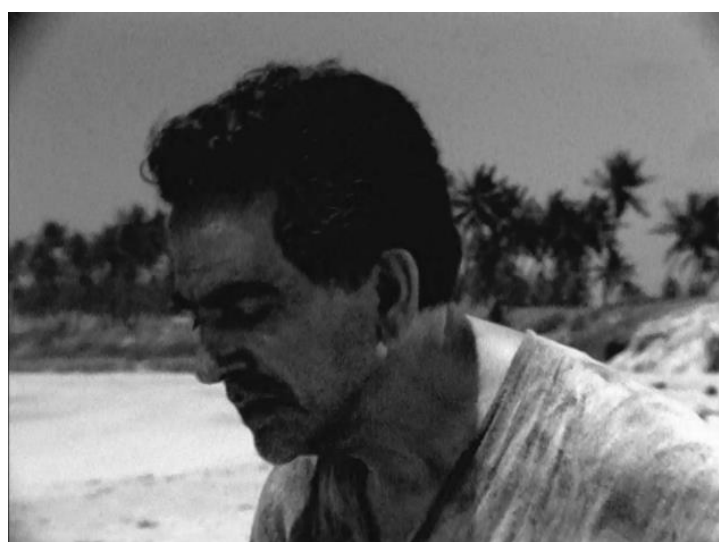

4 - Mais uma vez sem resposta.

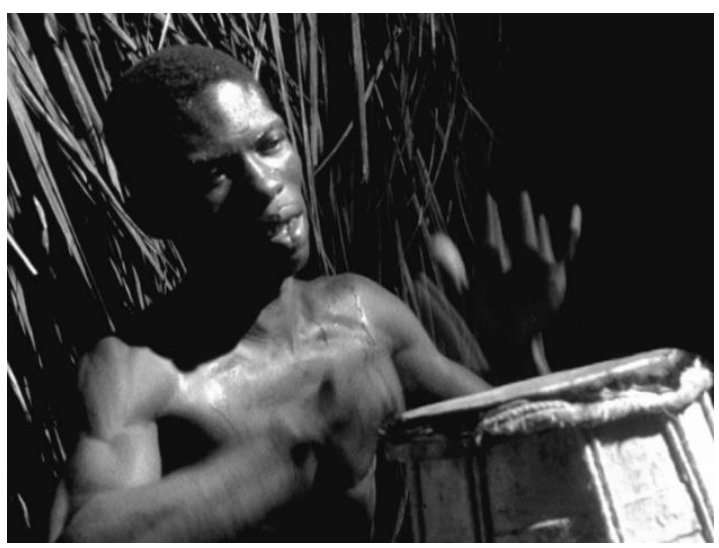

6 - Retomada do toque pelo ogã.

Na sequência acima, uma série de cantos de puxada são bruscamente silenciados pelo batuque do Ogã (o mesmo da introdução do filme). Daí por diante tudo o que se pode ouvir são os sons da arrebentação e o toque de atabaque que cria uma moldura para a cena. É como se a suspensão temporal trouxesse à tona a dimensão subjetiva da coletividade: por um lado os pescadores estão entusiasmados com a ousadia de Aruan e se lançam ao mar, por outro, há espera, melancolia, solidão, expectativas. Naína, por sua vez, vem correndo pela praia em uma busca individual de explicações para seu despertencimento: crer ou não crer? Adotar ou não os preceitos da religião? Em um momento de manifesta solidariedade e reintegração do conjunto social, Naína procura compreender qual o seu lugar no todo.

A presença do Ogã nesse excerto sugere a intromissão de causalidades extratemporais na interação entre Seu Vicente e Naína. O silêncio do pai com relação às muitas indagações da jovem cria uma lacuna, uma disjunção comunicativa estranha que diz 
respeito à identidade da personagem. O que não está sendo dito? A procura por uma resposta é atendida mais adiante: assim como o esclarecimento da identidade de Aruan revela sua natureza urbana, externa ao universo praieiro, a anagnorisis de Naína provém do desvelamento da identidade de seus pais, completamente ligadas à memória local. Uma vez que o papel da jovem está intimamente ligado à revitalização dos mitos fundadores do vilarejo, a sua inserção dentro do sistema de valores da comunidade é viabilizada: ela passa a pertencer porque participa da mesma matéria mítica que envolve os seus conterrâneos.

Naína ocupa no presente uma posição muito semelhante à que desempenhou no passado quando o sistema religioso já tinha sido desequilibrado:

No passado

$$
\begin{gathered}
\text { Joaquim } \\
\text { Protegido de Iemanjá } \\
\text { "Branco mais acreditava" }
\end{gathered}
$$

No presente

$$
\begin{gathered}
\text { Aruan } \\
\text { Protegido de Iemanjá }
\end{gathered}
$$

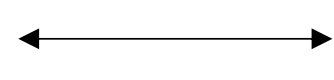

Naína
Isabel

Malquista

"Ninguém gostava dela"

Cota

Malquista

Em ambas as temporalidades, Naína está no meio de um par proscrito, antes, como fruto da relação profana, agora, como pretendente do jovem sob preceito, compondo um "triângulo amoroso" entre o protegido e a mulher malquista. Sua branquitude mestiça lembra, no presente, o signo da profanação das relações sagradas no passado, e a necessidade de cumprimento da profecia segundo a qual ela deveria ser entregue a Iemanjá. Metaforicamente, o plano sagrado se reequilibra aglutinando e sacralizando o que lhe é externo: no passado, Naína, como progênie do casal transgressor, no presente, mais uma vez Naína, como pretendente do novo transgressor.

A jovem mestiça fica sendo, dentro deste contexto ficcional, um símbolo do encontro entre duas dimensões em princípio inconciliáveis da moralidade conservadora, que tende a colocar a mulher negra hipererotizada como princípio desestabilizador da ordem - esse dado, analisaremos no item que se segue. De um lado, há a comunhão do coletivo com os preceitos, do outro a vida autossuficiente e desbragada, a libertinagem. O lugar incômodo do mestiço explica a avaliação que Chico faz do temperamento estrambólico de Naína: "É tudo por causa da cor dos olhos e do cabelo". 
Naína não é um caso isolado de mestiço melancólico dentro do Ciclo Baiano do Cinema, ${ }^{125}$ o que indica talvez a emergência de um tema social absorvido pelo universo da ficção fílmica: a representação dos filhos de relações entre indivíduos negros e brancos como seres desajustados - de forma mais ampla, pode-se vislumbrar a complexidade das tensões raciais brasileiras. Aqui falamos em representação de indivíduos negros, mas é importante ter em vista dois aspectos:

a) A imagem do homem e da mulher negra e da cultura afro-brasileira dentro daquele que é institucionalizado como o cânone brasileiro das artes é quase sempre definida sob o viés de homens brancos de elites econômicas e culturais, o caso do filme em questão não é diferente. Glauber, Luís Paulino dos Santos, Robatto Filho ou Jorge Amado, até onde se sabe, não se identificavam como homens negros;

b) No final dos anos 1950 o cinema nacional, e notadamente o novo cinema baiano, passam a dar protagonismo a homens e mulheres negros dentro de uma perspectiva distinta daquela que se instituía até então, menos estereotipada ou ao menos procurando colocar em xeque o vício dos "exotismos", embora nem sempre tenham logrado esse objetivo. ${ }^{126}$

Feita essa ressalva, há certas semelhanças entre os entraves identitários de Naína e o protagonista de um filme baiano precursor de Barravento, o longa de Trigueirinho Neto, Bahia de Todos os Santos (1960). Nele, o personagem Tônio (Jurandir Pimentel) é visto desde a primeira sequência do filme acompanhando o ir e vir dos barcos no movimentado cais do porto, em Salvador. O corpo curvado sobre si mesmo, rosto pousado sobre os braços, olhar perdido em direção ao mar, seu semblante exprime um vago tédio e descontentamento que fazem pensar na apresentação de Naína.

Mais adiante, uma das razões do temperamento taciturno de Tônio é exposta em um diálogo de bar, com seus camaradas:

Manuel - Chega, Tônio, por favor, é melhor parar. Aqui os outros não levam a gente a sério.

125 Apud CARVALHO, Maria do Socorro Silva. A nova onda baiana: cinema da Bahia (19581962). Salvador: EDUFBA, 2003.

126 STAM, Robert. Multiculturalismo tropical, uma História Comparativa da raça na cultura e no Cinema Brasileiros. Trad. Fernando S. Vugman. São Paulo: Edusp, 2008. 
Tônio - Pro diabo, todo mundo! Compradores e essa cachorrada toda! Todos! Minha mãe, meu pai... quem sabe onde andará aquele infeliz. Mas um dia eu vou me vingar. Pensando bem, nem vale a pena.

Manuel - Quieto, Tônio? Você quer complicar a gente, é? Você é neto de Sabina. Se lhe ouvem, vai dar bolo.

Tônio - Neto de quem? Ah, todo mundo tem medo dela. Minha mãe também. Eu não, não tenho nada que ver com eles. Eu só vou lá por causa de... Homem, eu nem sei por que eu vou lá... É mesmo, por quê? Manuel - Para, Tônio.

Tônio - Sossega que eu não passo da conta, não. Mas um dia eu vou me vingar, pode escrever. Vai começar com meu pai.

Crispim - Pai?

Tônio - Tenho pai sim. Ele existe, e é branco!

A avó de Tônio, mencionada por Manuel (Geraldo Del Rey), é uma figura proeminente e respeitada dos candomblés locais. A busca de verossimilhança antropológica na representação fílmica também se faz presente neste longa: a Mãe Sabina é interpretada por uma ialorixá, Mãe Masú, ${ }^{127}$ assim como a Mãe Dadá de Barravento. Da mesma forma que no longa de Glauber Rocha, o terreiro é de uma vertente praieira hoje pouco vista, segundo testemunho de Jaime Sodré. ${ }^{128} \mathrm{O}$ filme registra também a repressão policial sobre a população negra, aqui retratada pela violência das "forças de ordem" do Estado Novo sobre as religiões afro-brasileiras, com a queima de um altar e a perseguição de Mãe Sabina.

Como se percebe no diálogo transcrito acima, a perplexidade diante da parentalidade mestiça explica em parte o desconcerto de Tônio no mundo. De um lado a secularização branca do pai ausente, de outro a mãe negra ligada ao substrato cultural e religioso afro-brasileiro. Da mesma forma que Naína, Tônio experiencia um vácuo na comunicação com sua mãe, enferma e sorumbática como Seu Vicente. A hesitação entre dois eixos sócio-raciais aprofunda, na verdade, a dificuldade de inserção de Tônio e Naína em seus respectivos núcleos. Naína se pergunta sobre seu vínculo com a religião, sendo

127 CARVALHO, Maria do Socorro Silva. A nova onda baiana: cinema da Bahia (1958-1962). Salvador: EDUFBA, 2003, p.103.

128 SODRÉ, Jaime. Testemunho em Barravento. Direção: Glauber Rocha. Bahia: Iglu Filmes, 1961. 2 DVD (80 min.). 
branca. Tônio se queixa da falta de oportunidades pela cor da pele. Com efeito, ambos renegam seu vínculo intrínseco com o candomblé e com a matriz negra de suas identidades, até serem impelidos, por diversas circunstâncias, a reatarem os laços.

Nos dois filmes, o candomblé em sua variante praieira, embora participe da dinâmica social citadina, sobretudo entre as classes sociais menos favorecidas, está mais próximo de Itapuã, afastado do núcleo urbano onde as questões socioeconômicas criam novas dinâmicas de violência com choques de classes. É evidente que a repressão chega também a Itapuã, quando no filme de Trigueirinho Neto vemos a cavalaria policial atacando os barracões praieiros, mas há uma demarcação de espaços, e a praia evoca sobretudo o lugar "das origens", familiares ou espirituais, mais próximo à natureza, em contraste com a capital onde a luta por inserção social se impõe. Tônio se debate para subsistir na cidade, tendo o vínculo parental materno na província. No roteiro original de Barravento, Firmino, ao tentar levar Naína para a cidade consigo, diz que ela é "fillha de gente da cidade" - e assistimos à sua dificuldade de inserção no sistema provinciano.

Mais uma vez, a tensão entre os espaços cidade-província orienta as dificuldades intrínsecas das personagens e a fragmentação de sua identidade, mas aqui, reverberando na problemática da identificação racial.

O roteiro original de Barravento revela ainda dados mais prosaicos nas hesitações de Naína com a religião. Isso está ligado ao fato de que, a princípio, ela não se caracterizaria como uma personagem tão arredia e desajustada como conhecemos, ou tão interiorizada. Naína tomaria parte no samba de roda, interagiria com Cota, Firmino, Rosa, Dona Clara - muito mais comunicativa e extrovertida, portanto.

Quando instigada a fazer o santo, Naína justificaria sua recusa evocando o tempo de camarinha, em que não poderia estar perto do pai. Assim, nessa versão da história temos uma personagem que participa nos processos sociais, conhecedora da religião e autoconsciente: "É muito tempo [na camarinha], Clara, pai pode morrer, vou me embora" (Sequência 24, planos 225-254). Mais adiante ela chega a dizer que queria conhecer o reino de Iemanjá, no fundo do mar.

O mistério em torno da recusa ganha ares de vaidade mais tarde, quando Naína se confessa para Dona Clara: na verdade sabia dos olhares das demais mulheres sobre si, e recusa o Santo não por preocupação com o pai, sabia que os demais se ocupariam do velho. Dona Clara decifra a jovem ao vê-la passar a mão nos cabelos "fagueira": na verdade, Naína, apegada à sua autoimagem branca, não queria raspar a cabeça (Sequência 
52, 483-488). No candomblé, a raspagem dos cabelos é uma das principais etapas dos ritos propiciatórios de "preparação do santo", quando os jovens iniciados, Iawôs, entram na camarinha. Roger Bastide explicita sua importância:

A fixação do Orixá na cabeça da filha não se faz senão lentamente, etapa por etapa, desde a entrada no santuário até o tenebroso mergulho que lhe marca o fim. $\mathrm{O}$ caráter progressivo destas etapas se manifesta por um conjunto de símbolos: os cabelos são primeiro cortados com uma tesoura, depois rapados; o crânio é primeiro regado com o sangue de animais de duas patas, depois de quatro patas; a carne é primeiro tatuada, depois são abertas incisões, etc. ${ }^{129}$

O que resta desse dado no filme realizado não é um diálogo entre personagens, mas se articula por um expediente da montagem:

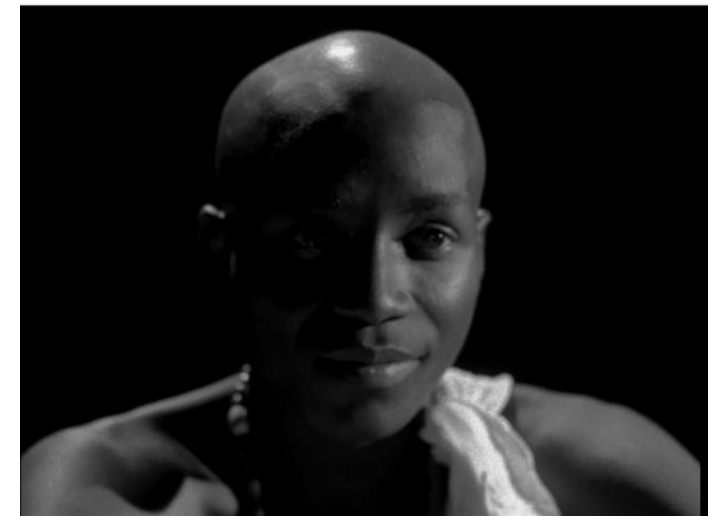

1 - Iawô em primeiro plano.

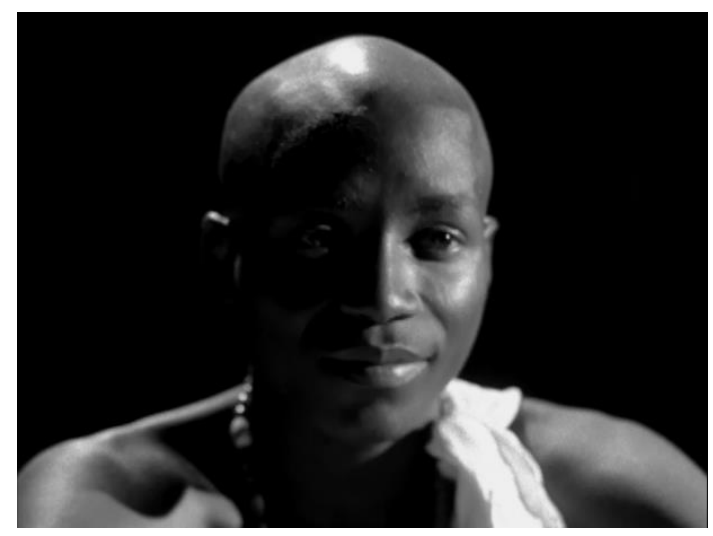

2 - Iawô novamente.

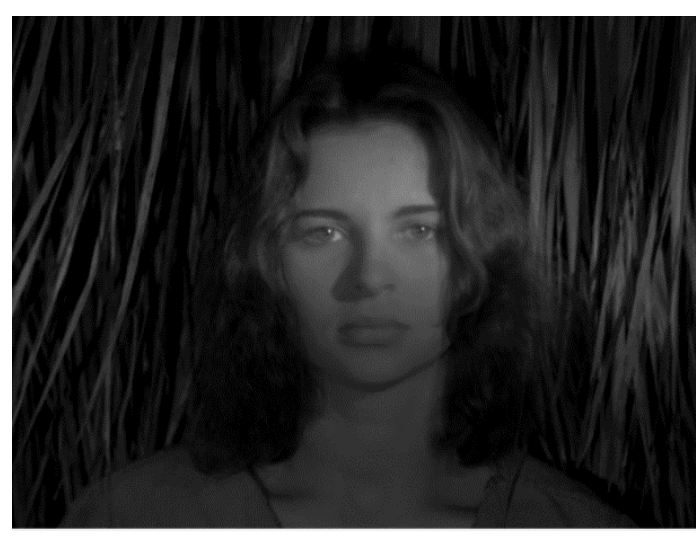

2 - Naína em primeiro plano.

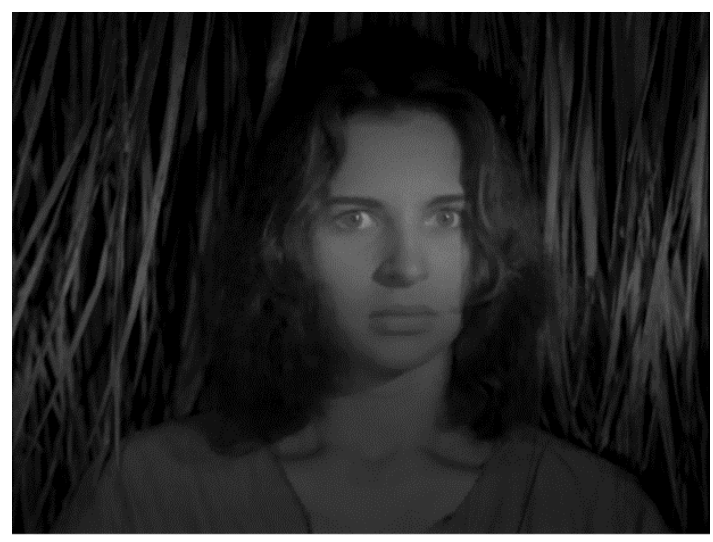

3 - Naína recusa acenando com a cabeça 

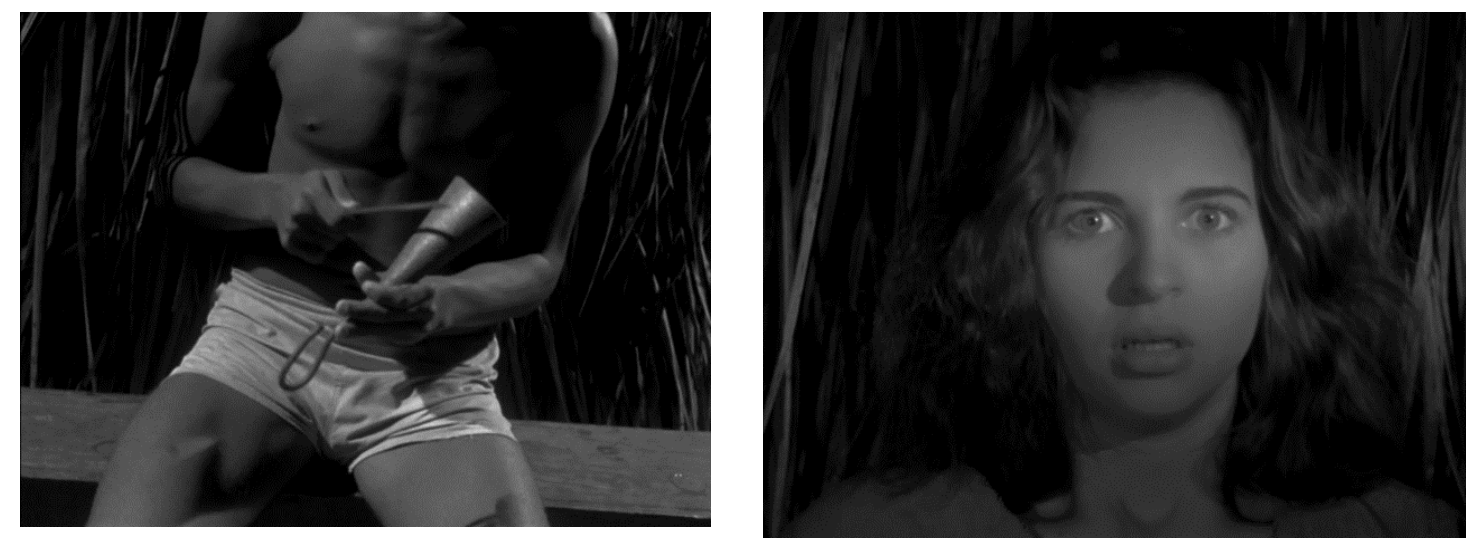

4 - Barracão, um tocador de agogô.

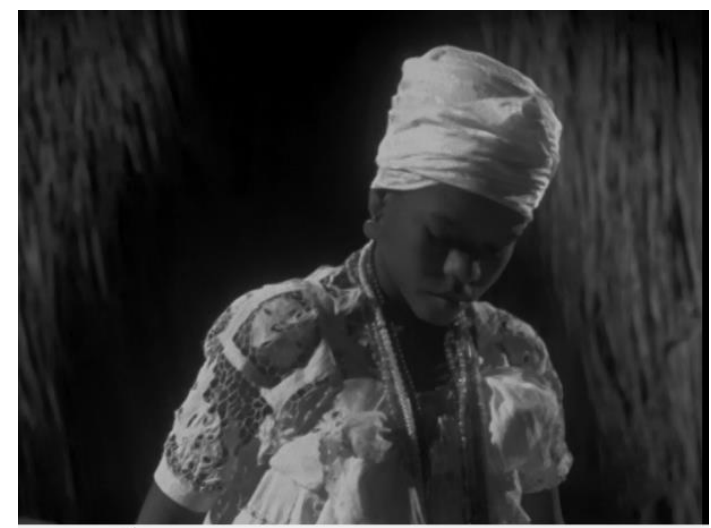

5 - Zoom, o terror crescente de Naína.

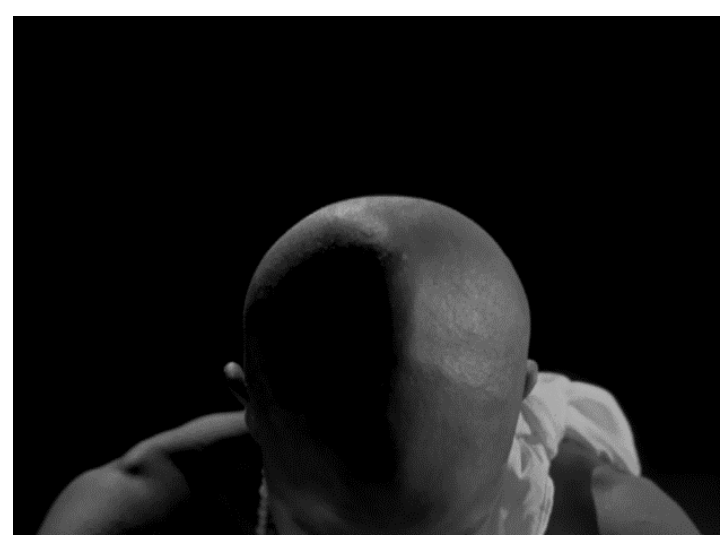

6 - Filha de Santo dança no barracão.

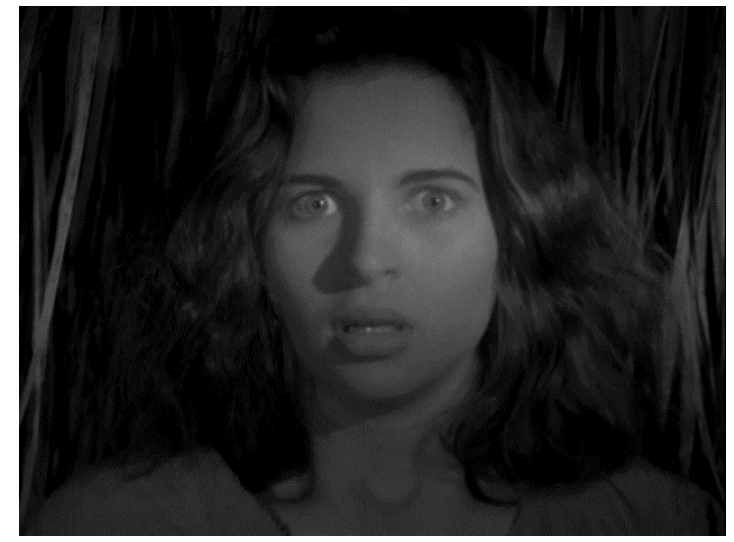

7 - Cabeça do Iawô em detalhe.

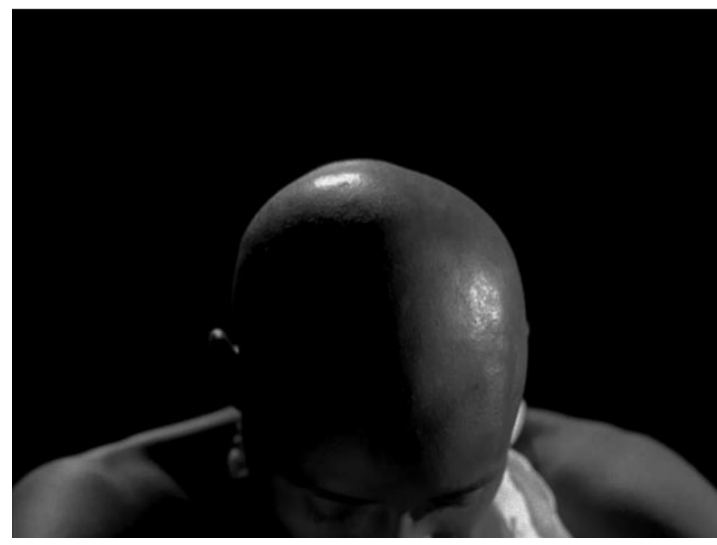

8 - A câmera se aproxima de Naína.

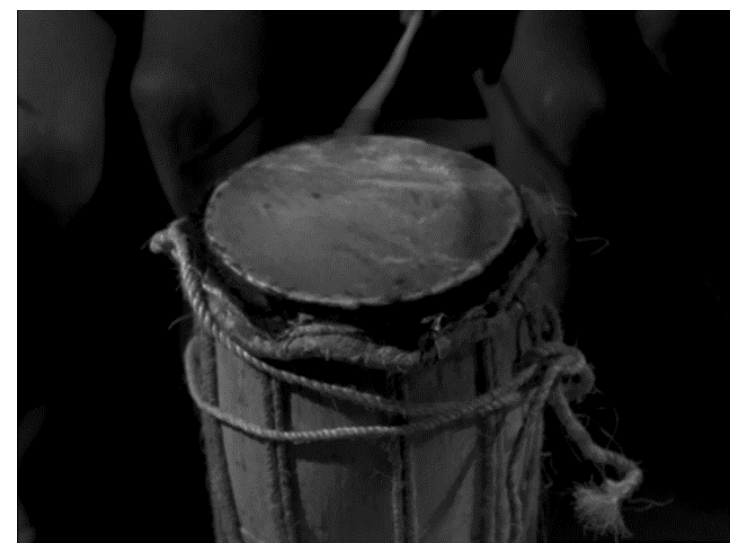

8 - A câmera se aproxima do Iawô.

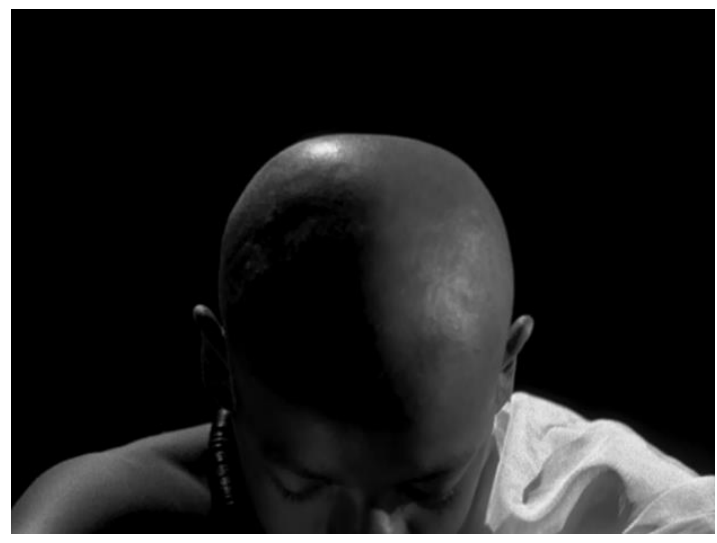




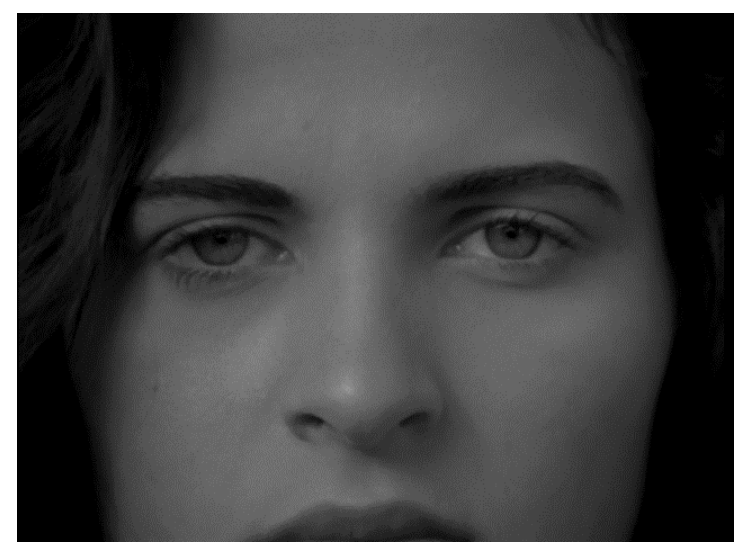

10 - Em detalhe, olhar de Naína.

Naína entra pela primeira vez na camarinha. Envolvida pela atmosfera crescente de imersão espiritual ela revela sua suscetibilidade ao Santo e "bola", como se denomina o ato da incorporação brusca induzido pela liturgia sem que o indivíduo seja iniciado.

Quando alguém é possuído por um "santo bruto" e desaba finalmente no chão, deve ser transportado para o aposento em que o babalorixá vai "matar o santo", isto é, fazer o paciente retornar ao estado normal. A queda ao solo corresponde à morte da personalidade antiga e o rito de "matar o santo", à ressurreição; o ser que renasce não é mais, naturalmente, a personalidade antiga e sim um novo "eu" daí por diante divinizado. ${ }^{130}$

O jogo de câmera dentro do barracão assume um caráter subjetivo ao concatenar uma série de elementos litúrgicos enquadrados em detalhe segundo um ritmo cada vez mais acelerado, conduzindo Naína ao transe. O ritmo imersivo se interrompe quando a jovem é levada para o interior do barracão ao som do adjá da Mãe de Santo, seguindo com exatidão os processos referidos acima por Bastide. Lá dentro, ela entra em contato pela primeira vez com a realidade concreta da iniciação. A sequência acima, como continuidade da câmera subjetiva, mostra o momento em que Naína contempla os jovens iniciados, Iawôs, que cumprem sua reclusão no aliaché.

A continuação da sequência retoma a toada crescente dos batuques rituais no barracão, agora registrando de forma cada vez mais cerrada o temor de Naína diante da 
imagem do jovem iniciado de cabelos raspados. Em detalhe, a câmera chega a confrontar o seu olhar com a cabeça raspada do iniciado. Observe-se como o enquadramento vai justapondo os elementos sagrados cada vez mais próximos e rápidos em contracampo à Naína acuada, até o close definitivo em seus olhos que parece dialogar com a fala inicial de Chico: "é tudo por causa da cor dos olhos e dos cabelos." Provavelmente por conta da "ressurreição" de que Bastide nos fala acima, Mãe Dadá faz a confirmação do Santo. Mas após a indicação da camarinha Naína foge do santuário.

Junto com o samba de roda e o jogo de capoeira entre Aruan e Firmino, esta é uma das sequências mais longas do filme, o que demonstra uma inclinação ao retrato antropológico na representação do fato cultural. Não se pode dizer, contudo, que não existam algumas incorreções, talvez fruto de licença poética. Por exemplo, já no fim do filme, quando Naína corre ao encontro de Aruan com a indumentária de Iemanjá. Na verdade, a vestimenta do Santo só é usada em transe, dentro do santuário e durante os ritos propiciatórios.

É digna de nota, por fim, a polêmica em torno do corte de cabelos, que valeu até certa animosidade entre Glauber Rocha e Ruy Guerra. Isso porque, realizado quase à mesma época, o filme $O$ cavalo de Oxumaré (1960), dirigido por Guerra, também encenava a raspagem dos cabelos de uma mulher branca, interpretada pela atriz Irma Álvarez, durante sua iniciação ao candomblé. Glauber foi à imprensa acusá-lo de plágio. Para a moralidade conservadora da época, o realismo da cena, sobretudo por ser a explicitação do corte dos cabelos femininos, era algo chocante. ${ }^{131}$

Ainda assim, a disputa pelo pioneirismo dessa cena em que a atriz branca performa um ato "pouco convencional" dentro de um contexto cultural afro-brasileiro, tradicionalmente marginalizado, revela não apenas o conservadorismo em torno da representação do corpo feminino. Também está em jogo a incômoda associação de um corpo tipicamente ligado à castidade cristã ao universo cultural negro, fonte de mistificação e exotismo erotizantes pelas elites intelectuais brancas. Vem à tona,

$131 \quad$ Em 1976, Glauber escreve: "Durante as filmagens estouram na imprensa fotografias de Irma Álvarez com a cabeça raspada num candomblé. Ruy Guerra filma o curta metragem $O$ cavalo de Oxumaré, escrito por Miguel Torres e produzido por Carlos Niemeyer. Enciumado abro a boca na imprensa nacional denunciando o português Ruy Guerra como plagiador. Escandalosamente arbitrário reivindico a posse da cabeça raspada". ROCHA, Glauber. "Anecy Rocha” in Revolução do Cinema Novo. São Paulo, Cosac \& Naify, 2004. p.336 
novamente, o protagonismo mal disfarçado atribuído ao indivíduo branco mesmo nos espaços de expressão afro-brasileira.

A questão coloca em prisma o tratamento muito distinto que é dado à representação da outra protagonista feminina de Barravento: Cota.

\subsection{Cota, a imolação da mulher negra}

Em 1968, Glauber Rocha concede uma entrevista ao crítico francês Michel Ciment na qual passa em revista a sua primeira obra, sobretudo a trilogia Barravento, Deus e o diabo na terra do sol e Terra em transe. Nessa entrevista, publicada pelo periódico de crítica cinematográfica Positif, afirma:

Michel Ciment: Os personagens femininos em Deus e o diabo têm um papel mais importante do que geralmente se pensa.

Glauber Rocha: Essa observação me foi feita muitas vezes e nunca cheguei a um comentário realmente objetivo a respeito. Em Barravento, Deus e o diabo, e também Terra em transe as mulheres têm consciência do que se passa, consciência da "história". Em Barravento, um personagem feminino dá sua própria vida como exemplo, se sacrifica pelo povo, leva um homem a assumir uma posição política e morre. Eu tenho muita dificuldade em trabalhar com personagens femininos, que são comigo sempre muito conscientes e têm influência moral ou política. ${ }^{132}$

A representação feminina em Barravento, de Cota a Naína, atravessa uma problemática que diz respeito à sujeição da imagem da mulher negra nas artes brasileiras ao campo do exotismo - seja na Literatura, uma das matrizes da obra cinematográfica de Glauber Rocha, seja nas artes visuais ou na canção.

Celso Prudente, em seu estudo antropológico do negro como referencial estético do Cinema Novo, ${ }^{133}$ enuncia a questão da mulher negra dentro do cânone literário como de um indivíduo sistematicamente associado a uma perspectiva erótico-utilitária da vida.

\footnotetext{
132 ROCHA. Revolução do Cinema Novo. p.115.

133 PRUDENTE, Celso. Barravento: o negro como possível referencial estético do Cinema Novo de Glauber Rocha. São Paulo: Editora Nacional, 1995.
} 
Na prosa ou na poesia, de Gregório de Matos, passando por Bernardo Guimarães, Aluísio Azevedo até Jorge Amado, a personagem feminina negra remete comumente à aventura sexual, o que Prudente denomina "o caráter pecaminoso da mulata" . $134 \mathrm{O}$ estudioso afirma ainda que os raros casos de transposição do polo negativo para o positivo da moralidade cristã, do pecado para o recato, acompanham o "embranquecimento" dessa figura feminina, como em A escrava Isaura.

Os registros iconográficos parecem apresentar a mesma tendência, desde os primórdios da prática de uma arte pictórica de matriz ocidental no Brasil. Yolanda Lhulier dos Santos, em O negro na iconografia do século XIX ${ }^{135}$ nos dá como exemplo da representação lúbrica colada à imagem da mulher negra as aquarelas de costumes de JeanBaptiste Debret, em sua Viagem pitoresca. No caso da prancha citada pela autora, "Casamento de negros pertencentes a uma família rica", na qual se vê uma cena de matrimônio entre dois escravizados, arranjado pelos senhores abastados, observe-se o como o próprio artista, em comentário, descreve física e moralmente a personagem feminina:

Digno de nota é o fato de que a negra, dotada extraordinariamente de sensualidade, ainda que fiel e casta no casamento, não resiste ao desejo de conquistar o amor do seu senhor por meio de cuidados particulares e da expressão graciosa de sua comovente afeição, disfarçada sob a aparência de humildade. Essa artimanha, deve-se dizer, é bem sucedida em todas as circunstâncias. ${ }^{136}$

O excerto acima demonstra como a ideia de uma lubricidade inelutável e resistente à castidade do rito cristão, supostamente inerente à mulher negra, é naturalizada pelo discurso do artista, ainda que a própria imagem não esteja a serviço dessa perspectiva.

Ao nos aproximarmos da contemporaneidade de Barravento, ponto culminante de um período de autoconsciência e valorização da cultura baiana no século XX, a questão da representação do negro volta à tona, por ser uma das principais matrizes da cultura do

\footnotetext{
$134 \quad$ PRUDENTE, op. cit., p.24.

135 Apud PRUDENTE, op. cit.

136 BANDEIRA, Julio e LAGO, Pedro Corrêa do. Debret e o Brasil: obra completa, 1816-1831.

Rio de Janeiro: Capivara, 2017, p.163.
} 
Recôncavo (o que Antonio Risério denomina o "tripé luso-banto-iorubano"). Diversas manifestações da produção literária e musical retomam e complexificam os estereótipos, mas sempre muito pré-moldados por uma concepção dominante heterossexual-masculina.

O cancioneiro de Dorival Caymmi se destaca dentro da produção artística baiana moderna como obra que se nutre de um imaginário oriundo da cultura afro-brasileira, dando-lhe centralidade. O compositor formula uma série de tópicos comuns que serão retomados e encenados no campo cultural, inclusive no Barravento de Glauber Rocha, pela representação da cultura afro-praieira, da religiosidade iorubá, do homem negro e, evidentemente, da mulher. No seu estudo da obra caymmiana, Uma utopia de lugar, ${ }^{137}$ Antonio Risério detecta dois grandes moldes de representação da mulher negra: uma de caráter urbano e outra, praieira.

$\mathrm{Na}$ imagética praieira a figura feminina (negra) é tida como subserviente e secundária. O que prevalece simbolicamente na ordem pesqueira é a dinâmica do trabalho coletivo protagonizada pelo homem, cabendo à mulher um campo subjetivo restrito: da sujeição, da espera angustiada do marido, da reza e em situação limite, da loucura. Há implicações evidentes também na economia do trabalho. Segundo nos informam os documentários sobre a puxada do xaréu dirigidos por Robatto Filho nos anos 1950, as mulheres e crianças ocupavam a última escala na partilha do produto da pesca - o chamado lava-pés, peixes menores e não comercializáveis que ficavam presos à rede.

Há fidelidade sociológica aí. O mundo itapuãzeiro é um mundo masculino. Caymmi não inventa heroínas; não vai no sonho neoromântico de Amado e Ubaldo. Recria mulheres descalças, algumas vezes sensuais, mas, antes que tecer fantasias guerreiras, as confina à perspectiva doméstica. São mulheres que vivem em função dos homens, sejam eles filhos ou maridos. Uma prepara a cama, outra lava a roupa e Rosinha endoidece com a morte de Pedro. ${ }^{138}$

Em Barravento, essa mulher praieira recatada e submissa seria encarnada por Rosa (mesmo nome, aliás, da personagem da canção de Caymmi). No filme, essa personagem é difusa e pouco desenvolvida, mas o estudo dos roteiros originais revela sua

\footnotetext{
137 RISÉRIO, Antonio. Caymmi: uma utopia de lugar. São Paulo: Perspectiva, 1993. (Debates; v.253)

$138 \quad$ Ibid., p.85-86.
} 
importância para a trama na medida em que Rosa sublinha a relação inextricável entre a natureza cósmica, a espiritualidade e os acontecimentos.

É um fio narrativo que corre em paralelo: a gravidez de Rosa, esposa de Chico, uma típica esposa itapuãzeira, está visceralmente atrelada ao destino do barravento. Em dado momento a personagem diz que gostaria que seu filho fosse “como Aruan”. Quando o barravento estoura após a dessacralização de Aruan e que se dá o afogamento de seu esposo Chico, Rosa entra em trabalho de parto. Conforme demonstramos no item anterior, o primeiro roteiro previa que o difícil parto do filho de Rosa só se efetuasse quando os cabelos cortados de Naína fossem lançados ao mar, acalmando a fúria de Iemanjá. No reequilíbrio das forças espirituais, dava-se a entender que o recém-nascido seria o sucessor e substituto de Aruan.

Assim, Rosa representaria essa forma de mulher-fantasmagoria do universo praieiro, trágica, atrelada às forças do destino, um indivíduo sem grande autoconsciência, que não refuta a ordem dos valores tradicionais e integra a paisagem física como espiritual de Itapuã. É em larga medida a representação do elemento feminino ligado a uma ancestralidade mítica, a alegoria da mãe, casta e submissa, que dá à luz o novo salvador, o "messias".

Na Literatura, Jorge Amado também reincidiu nessa matriz. No romance Mar morto acompanhamos já de entrada a personagem Lívia que espera a volta de seu companheiro em uma noite de tempestade marítima. Enquanto aguarda no cais, ouve, ali perto, uma amiga tendo relações sexuais com seu amante, também marinheiro. Mais adiante, o narrador nos informa da morte de dois homens, Raimundo e seu filho, acometidos pela tempestade. Uma terceira personagem, Judith, amante do pai afogado, está grávida e deve receber a notícia, assim como Rosa em Barravento.

Só então ela sentiu toda a dor de Judith, se sentiu totalmente sua irmã, irmã também de Maria Clara, de todas as mulheres do mar, mulheres de destinos iguais: esperar numa noite de tempestade a notícia da morte de um homem.

$[\ldots]$

No entanto, a letra desta velha canção diz que a desgraçada é a mulher que vai com um homem do mar. Sorte boa ela não terá, infeliz destino é o seu. Seus olhos não pararão jamais de chorar, e cedo murcharão de tanto se alongarem para o mar, esperando a chegada de uma vela. [...] 
Hoje um negro canta também. Diz que destino ruim é o das mulheres dos marítimos. ${ }^{139}$

O narrador em terceira pessoa, assumindo a consciência de Lívia, atribui um caráter uniformemente trágico ao destino das mulheres do mar. $\mathrm{O}$ homem estando sujeito ao jugo cósmico de Iemanjá, as mulheres estão sujeitas às pulsões de vida e morte do homem, e padecem perpetuamente de sua ausência tanto em vida quanto em morte. Lívia, Maria Clara, Judith e Rosa sintetizam as condições da mulher dentro do sistema trágico androcêntrico: a espera, a disposição ao sexo, a procriação. Nesses signos femininos se espelha uma lógica incestuosa que borra os limites entre a função materna e conjugal. São mães-esposas que sublimam as necessidades carnais de filhos-esposos, heróis do mar.

Mas há uma segunda natureza feminina-negra dentro desse repertório poético caymmiano com que Barravento dialoga: a figura da mulher negra urbana, novamente, moldada por/para um olhar masculino heterossexual. E é nos sambas que essa extração urbana se manifesta, sistematicamente erotizada pelo eu-lírico.

É nos sambas, não nas canções praieiras, que a mulher toma conta da inspiração caymmiana. E é uma mulher sensual. A fêmea feliz na roda de samba. A criatura provocante que passa pelas ruas. Mulheres que se impõem pelo desejo que despertam. [...] Estas mulheres estão afastadas da figura tradicional da doméstica ou do padrão casamenteiro. Não há lugar para emílias e amélias nos sambas caymmianos. São mulheres que, premiadas pela beleza e pela sensualidade, conhecem o poder que têm. Conhecem e usam: o poder do corpo. E circulam com independência, dispondo à sua volta o grupo de admiradores. ${ }^{140}$

A associação entre o samba e a supererotização reificante do corpo negro feminino encontra eco em Barravento, através do olhar da câmera. Diga-se de passagem, a sequência do samba de roda é das mais complexas tanto na primeira versão do roteiro quanto no roteiro reformulado. Com um forte teor documental, a sequência 17 previa originalmente nada menos que 60 planos (121 a 181), ao passo que a sequência como

\footnotetext{
$139 \quad$ AMADO, op. cit., p.13, 16 e 17.

140 RISÉRIO, op. cit., p.86-87.
} 
conhecemos tem cerca de 18 planos. A versão de Glauber Rocha, colada separadamente à capa da brochura, descreve minuciosamente a ordem das "umbigadas", isto é, o movimento cômico-provocante que um indivíduo faz para chamar o outro ao centro da roda. Trata-se de um momento em que a harmonia se estabelece pelo gozo coletivo do jogo, gerando a manutenção da ordem social comunitária. As tensões anteriormente anunciadas entre Aruan e Firmino são atenuadas em torno da dança, para logo em seguida serem reacendidas, quando a roda de samba se transforma em roda de capoeira - a montagem entre planos e trilha sonora se encarregam dessa transição.

No que tange ao viés sexualizante sobre o corpo feminino, ele irrompe com força em pelo menos dois momentos do samba de roda, pelos expedientes da montagem e posicionamento de câmera. A título de análise, distinguimos 18 planos na sequência, tendo como início o quadro das mãos do Mestre Canjiquinha batendo percussão e finalizando com uma panorâmica sobre a roda que degringola no atrito entre Aruan e Firmino. Observemos:

a) Planos 3 a 6: A câmera em primeiro plano sobre Firmino registra sua expressão entusiástica, seu olhar ligeiramente baixado, seu gesto de bater palmas. O plano seguinte, subjetivo, mostra em detalhe as nádegas de uma jovem dançando. Não se trata de uma personagem nomeada no enredo. Vemos seus quadris sem lhe conhecermos o rosto. A concatenação desses planos parece emular o olhar do homem sobre os quadris da jovem mulher que samba, pouco antes de ela entrar no centro da roda, como se lhe concedesse apreciação sexual e passagem.

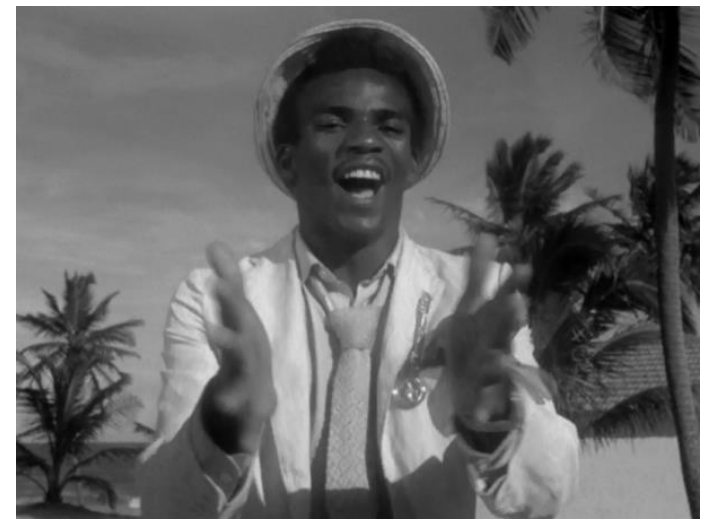

1 - Firmino em primeiro plano bate palmas.

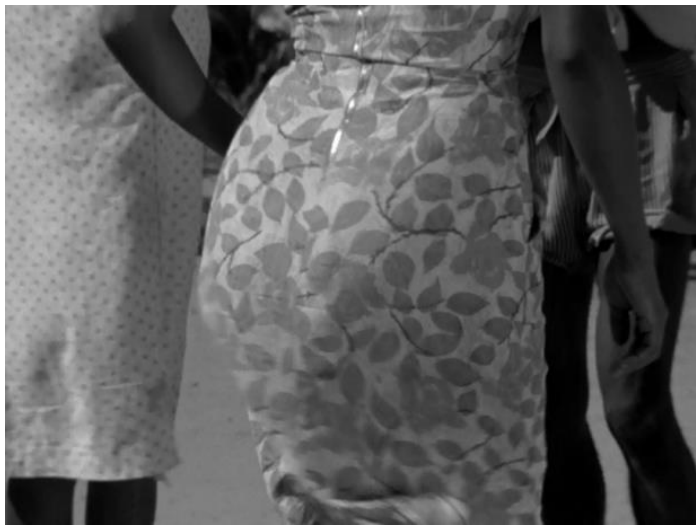

2 - Enquadramento sobre os quadris de uma jovem que está sambando. 


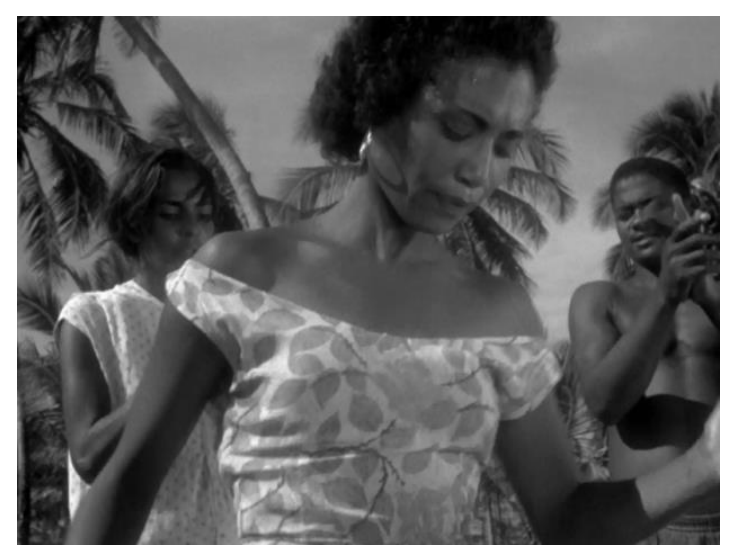

3 - A jovem vem para o centro da roda de samba.

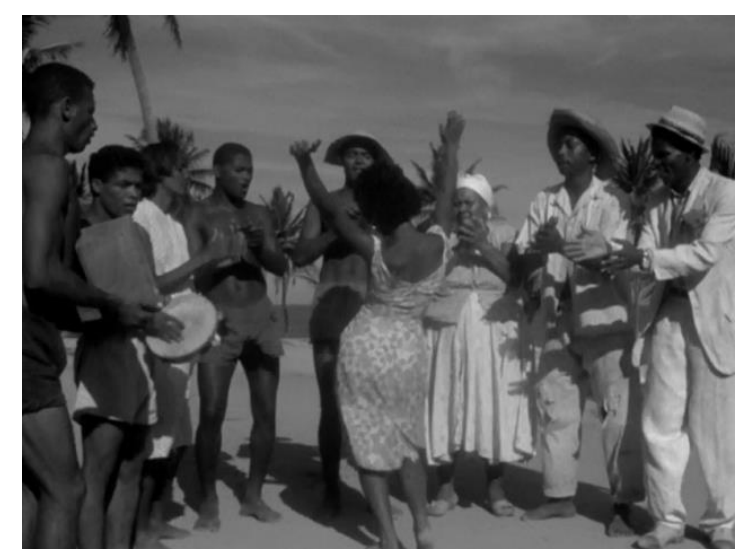

4 - A jovem de costas no centro da roda (dará a umbigada em Aruan).

b) Planos 13 e 14: a justaposição de contre-plongée e plongée sobre Cota cria um jogo de ênfases em torno do corpo da personagem. São salientadas formas estereotipadamente associadas à eroticidade da mulher negra - seios, quadris, nádegas.

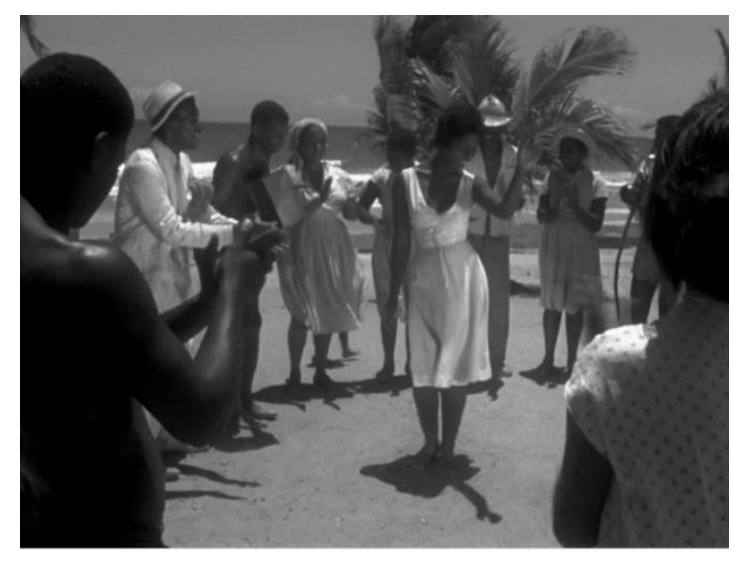

1 - Cota vem para o centro da roda.

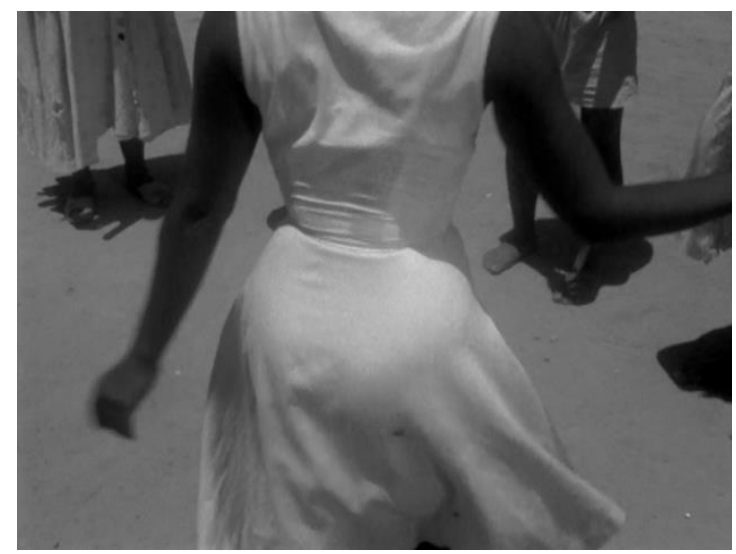

3 - Plongée sobre os quadris sambando.

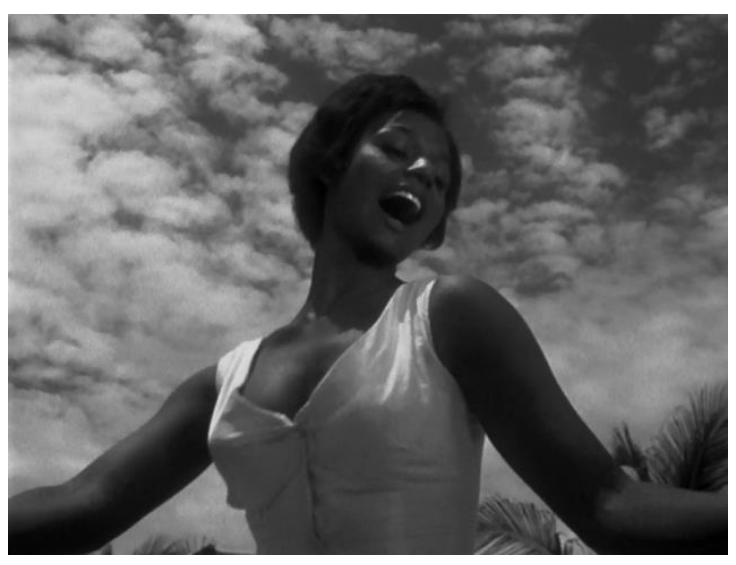

2 - Contre-plongée.

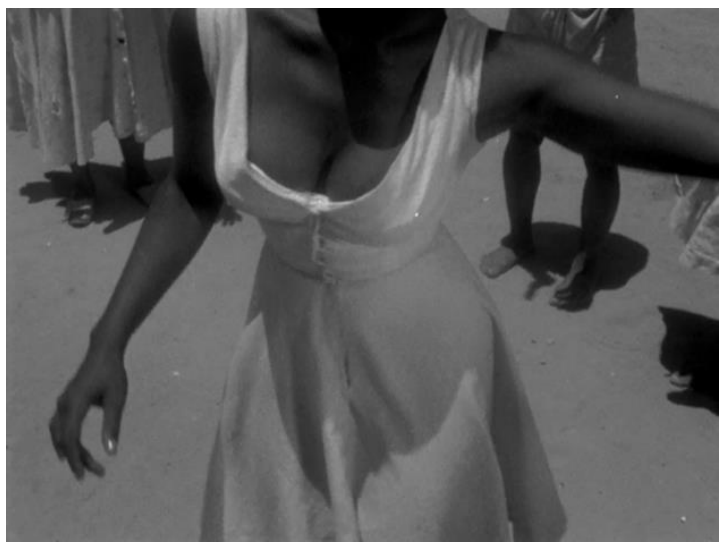

4 - Mesmo plano, Cota se vira, os seios em destaque, a cabeça e a expressão facial são dispensadas pelo enquadramento. 
Esse segundo conjunto acompanha uma mudança no tema do samba, colocando ainda mais em evidência o transbordamento do erotismo: "Que mulata bela / Ó que natureza / Se eu me casasse / Era uma beleza / Torno a repetir meu amor / Ai ai ai ". A combinação entre posicionamento de câmera e trilha sonora tornam a personagem não mais uma figura individualizada mas uma espécie de alegoria erógena baseada em uma série de clichês raciais.

Em toda a sequência do samba-de-roda os corpos masculinos são enquadrados mais à distância, com mais inteireza (planos gerais, médios, americanos), desprovidos de carga sexual ou ênfase às suas "sinuosidades", a não ser por uma curiosa exceção que merece análise por refletir um dado histórico-antropológico do samba-de-roda. Conforme mencionamos em análise anterior, o samba-de-roda, sendo uma vertente predominantemente modal da música de extração popular, tem caráter reiterativo. A mesma lógica se transfere para os movimentos coreográficos que, associados a temas conhecidos pelos praticantes do samba, compõem uma espécie de repertório coreográfico comum ligado a cantos recorrentes. Risério nos informa a propósito de uma dessas variantes estilísticas:

O samba-de-roda é intensamente sensual. Não só no ritmo e na dança, como também nos textos cheios de alusões e insinuações sexuais. "Ô tira a mão da flô, ô Fulô" - cantam os negromestiços da Cidade da Bahia e de todo o Recôncavo. "Flô" aqui significa "xota". E o canto é acompanhado por uma coreografia especial: as mulheres dançam com uma mão sobre a xota e a outra tapando o cu. ${ }^{141}$

Essa modalidade coreográfica figura em Barravento, no plano 6 da sequência em questão, mas contrariamente ao que propõe Risério, é performada por um homem, João: 


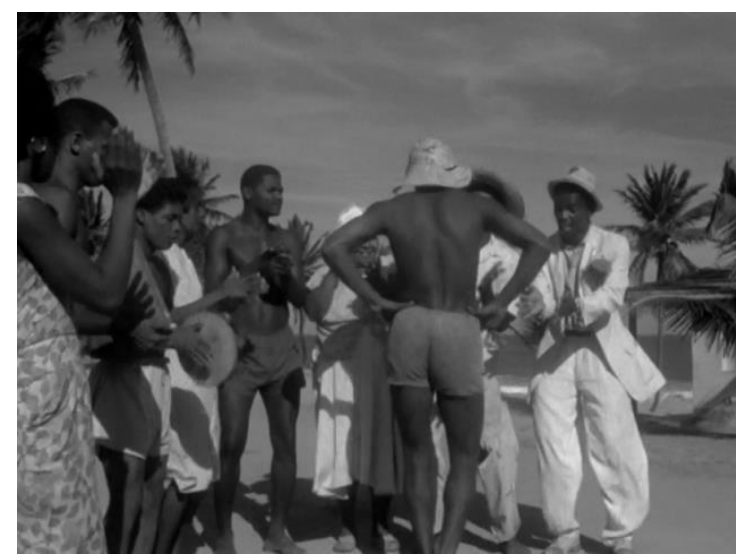

1 - Aruan entra no centro da roda e simula movimentos coreográficos "femininos" ao chamado do cantador. Ele dá a umbigada para João.

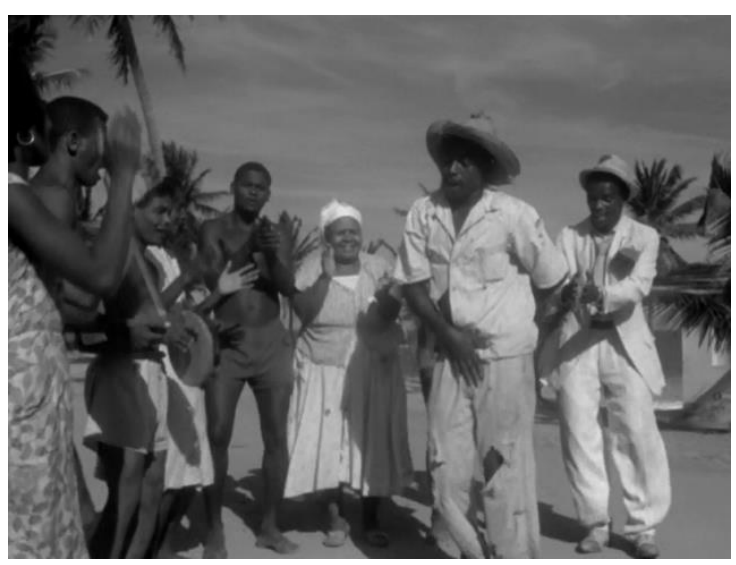

2 - João vem para o centro da roda coreografando com uma mão na virilha e outra na nádega.

A "inversão" de caracteres de gênero dentro de um contexto, do samba-de-roda, onde as figuras femininas e masculinas são tão tradicionalmente binárias não é arbitrária, mas conduzida pela letra que o cantador entoa (os segundos versos são sempre do coro):

Oh, quem bate em pandeiro é homem

Olô, Bahia

Quem bate palma é mulher

Olô, Bahia

Mas olha a flor da mangueira

Olô, Bahia

Mas olha a flor que mais cheira

Olô, Bahia

O instante que marca a "inversão da performance de gênero" nos trejeitos de Aruan é aquele em que o cantador diz "quem bate palma é mulher". Por sua vez, João performa com a mão na virilha quando a letra evoca "a flor da mangueira"/ "a flor que mais cheira", o que faz pensar na indicação de Risério da imagem da flor como alusão metafórica à vagina. Seus movimentos de quadril também se assemelham àqueles atribuídos às mulheres no samba. O divertimento revela uma dimensão lúdico-satírica do samba-de-roda. É possível que os participantes Aruan e João tenham se umbigado como forma de provocação e zombaria entre amigos, convocando-se mutuamente para uma brincadeira farsesca motivada pelo canto. Entretanto, o "disfarce do feminino" nesse caso 
não desmonta o binarismo rígido dessa estrutura comunitária tradicional, pelo contrário: a comicidade entre coreografia e letra cria um momento paródico que, pela inversão, reafirma/repõe as funções de gênero dentro daquela lógica social - é engraçado porque Aruan está imitando uma mulher, é estranho porque Aruan está imitando uma mulher, é engraçado porque é estranho.

Tais marcações são particularmente eloquentes dentro deste enredo, onde estão todo o tempo vibrando, mais ou menos simbolicamente, tensões de ordem sexual ligadas à representação da religiosidade iorubá: entre virilidade e virgindade, contenção e liberação, tabu e profanação - vide a análise de Ismail Xavier da sequência do barravento, em que um coqueiro passa a ser, no plano metafórico, uma extensão fálica do Aruan desvirginado. ${ }^{142}$

O próprio Glauber Rocha reitera a centralidade da função sexual em Barravento na célebre carta a Paulo Emílio Sales Gomes, escrita durante as filmagens, em novembro de 1960:

Ninguém age na miserável aldeia isolada, pois confiam na virgindade do jovem. [...]

Estou usando atores negros, fabulosos, vivos, flexíveis, quentes e cheios de violência plástica \& sensualismo [...].

Como Vadim, Malle e Bolognini, fiz do sexo um tema importante dentro do tema geral e espero, dentro de minhas modestas possibilidades de "nouvelle vague caipira" acrescentar alguma coisa na lista quando em um longo TRAV. uma negra fabulosa se despe e toma Aruan pelos flancos quebrando a virgindade do herói. Penso que será o primeiro herói deflorado do cinema. Você conhece algum outro? ${ }^{143}$

Glauber sintetiza o nó da trama nos termos de "virgindade" e "defloração". A tomada de consciência social do herói é análoga à defloração - que nos termos de Glauber, produz um sujeito revolucionário - ao passo que a castidade corresponde ao conformismo ingênuo e fatalista. Além disso, observe-se como Glauber sujeita o

142 XAVIER, Ismail. Sertão Mar: Glauber Rocha e a estética da fome. São Paulo: Duas Cidades; Editora 34, 2019, p.43

143 ROCHA, Glauber. Cartas ao Mundo (org. Ivana Bentes). São Paulo: Companhia das Letras, 1997. p.126-128. 
indivíduo negro a um "eu" criador prepotente e externo ("estou usando atores negros") e o grau de idealização estereotípica, evidente no uso do adjetivo "fabuloso" que se repete tanto na descrição dos corpos negros quanto de Cota.

O discurso naturaliza uma série de associações ao corpo negro em uma gradação reificante: atores negros, logo corpos proeminentes, logo violentos, logo sensuais. E no fim, a estetização desses corpos resvala quase que naturalmente na função sexual da mulher negra. $\mathrm{O}$ diretor apresenta como novidadeira a preponderância feminina no processo de sedução, a defloração do homem. O que coloca no centro da problemática a personagem Cota com toda a sua carga hiper-sexualizada (a começar por esse nome, talvez a contração de "cocota", que associa beleza física e erotismo aflorado). ${ }^{144}$

Muito se disse na crítica sobre o caráter marginal e ambíguo da ação de Firmino dentro do coletivo da aldeia de pescadores, mas há uma polivalência equiparável em Cota, como uma consciência dissonante no uníssono da vida comunitária, solitária em grande medida, malquista e, por fim, proscrita. Cota, como Firmino, tem um pé na dimensão material da existência e outro, no trágico-mítico. Vejamos de que forma a complexidade de Cota se evidencia em três de suas falas:

Cota: Não meto minha mão no fogo. Fiz meu santo e respeito o dos outro. O de Aruan então... Se ele gostasse de mulher talvez eu não andasse tão jogada fora.

(Firmino lhe dá um tapa)

Olha velho, eu não dependo de nada na vida. Não tem gente da cidade que passe por aqui sem baixar os beiço. Eu me viro a hora que bem quero. A carne é minha e quem faz o preço sou eu.

No excerto acima, Cota reage às profanações de Firmino contra Aruan, e demonstra uma consciência respeitosa dos preceitos da religião iorubá. A feitura do santo representa o ápice da consagração dentro da doutrina candomblezeira: "o controle da vida mística, a associação do indivíduo com seu Orixá, a incorporação de um novo membro

\footnotetext{
144 Uma outra hipótese (a desenvolver) para o nome de Cota: no candomblé de Nação Angola, aquele de matriz banto, cuja língua litúrgica é o quimbundo, a Kota é uma sacerdotisa cuidadora das divindades (Nkisis), mais ou menos como uma ekedi nos candomblés Ketu e Jeje. Trata-se de uma facilitadora, um tipo de mensageira nos trâmites entre o divino e o humano. É um posto prestigioso que só pode ser ocupado por mulheres.
} 
na confraria religiosa, a morte e a ressurreição do candidato." ${ }^{145}$ Nesse quesito, da manutenção dos preceitos religiosos, a jovem é um indivíduo ligado harmonicamente ao seu conjunto social e cultural, de modo que, ao menos até a chegada de Firmino na aldeia, sua perspectiva espiritual era sobretudo positiva e alinhada aos valores tradicionais. Ainda que já demonstre um interesse afetivo em Aruan, a barreira auto-imposta é a religião.

O mesmíssimo trecho, entretanto, apresenta uma segunda natureza, contraditória, mais marginal e reativa, esta sim totalmente diversa da comportada mulher praieira caymmiana. Trata-se da autoconsciência do corpo e liberalidade sexual. Se Firmino se coloca como um indivíduo politicamente consciente e avesso à repressão dos valores tradicionais, Cota manifesta uma força simbolicamente descompressiva da sexualidade feminina em um ambiente moralmente castrador e estreito.

Em sua consciência, seu corpo não é totalmente sujeito à fatalidade do destino ou extensão da paisagem, é seu instrumento de imposição e um domínio de poder. Ela parece capaz de subjugar a ordem externa pelo conhecimento de sua sexualidade, à revelia de interesses momentâneos, sem, contudo, refletir uma vontade política ou revolucionária consciente. A frase "a carne é minha e quem faz o preço sou eu" indica por um lado a afirmação da vontade individual da personagem, por outro, expõe o corpo como meio de exploração econômica em potencial, acusa a prostituição e revela em Cota uma matriz muito mais urbana do que propriamente praieira ou provinciana.

Eu bem disse, meu bem, serenou

Que não fosse pro mar, serená.

Você foi não voltou, serenou

Que me importa que vá, serenou, serená.

O trecho acima é uma pequena canção entoada por Cota. Nesta sequência, Aruan decide passar a noite no mar para consagrar seu santo e reacender a coragem dos pescadores, provando seus poderes junto a Iemanjá. Há um enquadramento em primeiro plano sobre Cota, deitada na rede, cantarolando languidamente em sua varanda. A princípio, entende-se que está melancólica pela partida de Aruan, e o estribilho sublinha

145 BASTIDE, Roger. O Candomblé da Bahia - Rito Nagô. Trad. Maria Isaura Pereira de Queiroz. São Paulo: Companhia Editorial Nacional, 1961. p.41. 
o afeto contrariado, a angústia, o despeito pela ausência. Os sentimentos nutridos pelo jovem pescador, antes uma mera insinuação, são reafirmados nesse plano.

Com relação à canção, ao que tudo indica, trata-se de um tradicional estribilho praieiro. Há registros de uma gravação dessa estrofe, com ligeira variação, em um dos volumes da série de discos Viva Bahia!, que se originou do espetáculo de mesmo nome, encenado no Teatro Castro Alves de Salvador em 1968. O projeto de caráter documental encabeçado pela etnomusicóloga Emília Biancardi Ferreira procurou registrar um conjunto de manifestações musicais da cultura popular do Recôncavo, dentre as quais o candomblé, a capoeira, o samba-de-roda e, evidentemente, os cantos praieiros da pesca. Há um segundo registro, de viés mais comercial, datado de 1971, interpretado por Clara Nunes em seu quarto álbum de estúdio, sob o título revelador de "Puxada da rede de xaréu”. É um álbum que procura raízes na cultura afro-baiana como indicam os títulos "Aruandê... Aruanda", "Ê Baiana", "Misticismo da África ao Brasil".

Conforme afirmamos em outros momentos destas análises, uma das particularidades de Barravento, com relação à produção fílmica contemporânea a ele, é a ausência premeditada de uma trilha sonora comentativa. A canção, como gênero, é totalmente ausente no plano extradiegético mas figura em dois momentos muito pontuais da trama, pelas vozes de Firmino e Cota, uma escolha que evidencia a busca de efeitos precisos.

Na citação acima, a canção intradiegética de Cota vibra dentro do conjunto como mais um dos elementos brechtianos de Barravento. Por oposição à música comentativa, ela não vem apenas dar ênfase à carga emocional da sequência para amplificar a imersão na melancolia de Cota. Por um lado, sendo uma canção praieira, o momento musical revela uma busca de verossimilhança antropológica ao enraizar o substrato cultural da personagem mas, por outro, nas palavras de Rosenfeld sobre o teatro épico, entra em "atrito com outros elementos do conjunto". ${ }^{146}$ Como situá-lo e que tipo de controvérsia está em jogo?

O estribilho de Cota está emoldurado por uma série de planos aparentemente desconexos, alusivos à passagem do tempo e à vida cotidiana. Trata-se de um dos blocos mais heterogêneos em termos de linguagem fílmica, alternando cenas de caráter mais ou menos documental, de pesca e candomblé, com momentos narrativos nos quais

146 ROSENFELD, Anatol. Brecht e o teatro épico (org. Nanci Fernandes). São Paulo: Perspectiva, 2012, p. 125 . 
personagens mais velhas contam histórias do povoado, revelando pouco a pouco as origens e o destino de Aruan e Naína, na medida em que respondem às suas indagações. São fragmentos que se situam entre a resolução de Aruan e seu retorno épico do mar.

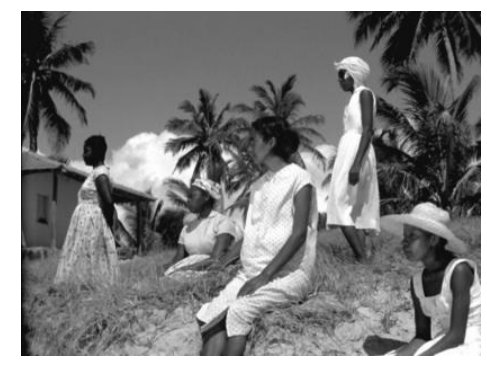

1 - As mulheres aguardam na praia.

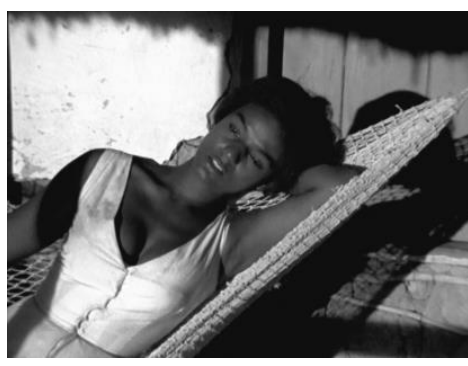

2 - Cota canta seu estribilho

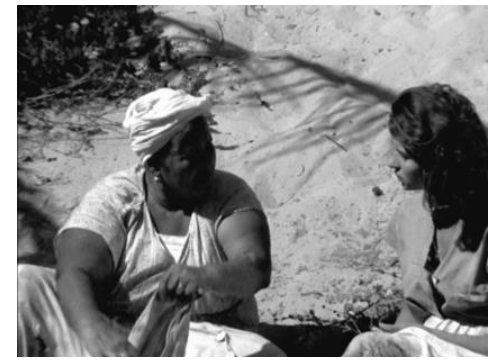

3 - "Isabel era sua mãe. Aqui ninguém gostava dela".

Nesse miolo, observe-se acima como os planos 1 e 2 se complementam e opõem estruturalmente: no primeiro, o panorama das esposas e mães anônimas (no centro Rosa, mulher de Chico, grávida) representa a espera resignada da mulher praieira, aquela retratada por Caymmi no seu cancioneiro - o contracampo evidente são o mar e os pescadores. Elas estão imóveis quase como os coqueiros da paisagem ao fundo, e se integram umas às outras por um silêncio submisso, nenhuma se destaca. No segundo plano, Cota, sozinha, domina a cena. Ao invés da atitude tácita e conformada das conterrâneas, ela canta sua melancolia e seu ressentimento. A ausência de explicitação de um contracampo nos faz pensar que olha muito mais para dentro de si do que para o horizonte oceânico, portanto muito menos movida pela tragédia coletiva do que pela experiência de sua subjetividade. Mergulhada no seu sentimento, ela vai e vem na rede. Tanto o balançar quanto a estrutura cíclica do estribilho parecem imitar o movimento da maré e o ciclo da vida praieira.

Assim, o encadeamento de 1 para 2 explicita o contraste entre a homogeneidade da vivência coletiva e a experiência individual, aprofundando o isolamento de Cota, ainda que a canção revele o seu pertencimento ao repertório cultural comum do mundo praieiro.

O terceiro plano vem consolidar essa construção de sentido. Nele, a Dona Zezé revela para Naína o que até então estava subentendido, que sua mãe era a finada Isabel de que o povo falava, malquista no vilarejo por seduzir o antigo preferido de Iemanjá, Joaquim, castigada com a loucura e uma morte trágica. A soma dos planos nos informa: Cota é a atualização, nessa geração, da Isabel do passado. Para tornar o vínculo ainda 
mais evidente: a terceira cena se desenrola às margens da sinistra Lagoa de Abaeté (onde as lavadeiras de Itapuã, temerosas, batem suas roupas, como na canção praieira de Dorival Caymmi), justamente o local onde Cota morrerá.

A repetição do ciclo trágico da mulher que se apaixona pelo homem proibido dá uma dimensão cósmica à morte de Cota. No roteiro, há algumas variações da sequência final dessa personagem, mais ou menos investidas de caráter místico. Embora a cena que conhecemos não tenha falas, a versão inicial previa uma imprecação ("Firmino, você me meteu no Inferno"), pouco antes do afogamento. Em outra versão, um tanto caricaturesca, a mão de Iemanjá persegue a jovem que corre alucinadamente para a morte.

A dimensão trágica que ganha a temática do tabu amoroso dentro de uma comunidade tradicional gerou entre críticos de primeira hora, como Alex Viany e Orlando Senna, aproximações com o clássico Tabu (1931), de F. W. Murnau e Flaherty. Com a diferença fundamental do conteúdo político, do elemento brechtiano, que devolve materialidade à composição das personagens. O sacrifício de que Glauber fala na entrevista para Ciment tem uma inflexão política por conta, ao nosso ver, do conteúdo histórico que vem à tona.

As citações 1 e 2 demonstraram que a problemática da inserção de Cota na comunidade implica, por um lado, uma série de elementos consoantes ao seu entorno, como seu preceito religioso e seu repertório cultural e, por outro, elementos divergentes, como a expressão libertária de sua sexualidade, a declarada emancipação moral no uso de seu corpo, os momentos de vivência subjetiva, mas também a sua realidade material e econômica, que passamos a analisar:

Firmino: [...] Se as coisas fossem diferente até que eu me arrumava. Cota: Ainda não fez porque não quer. A renda num dá?

Firmino: A renda mal serve pra ter uns pano decente em cima do corpo. Estou sem oportunidade, como diz um amigo. A ficha na polícia anda muito descarregada. E agora inventaram até uma palavra nova: "elemento subversivo".

Cota: Pelo nome parece coisa importante. É por isso que cê não se resolve? Se for por causa de grana, não tenha medo. Eu sou até rica, com as duas jangadas que o velho deixou pra mim. O negócio dá pra gente viver junto. Por que que você não endireita o caminho? Não vem viver como os outros. 
Firmino: Eu, pescador? Isso é vida de índio. Isso aqui não é África, é Brasil. Cota, no fundo meu coração presta e muito. Ando com você porque seu jeito é de quem não se abaixa. Aruan também não quer se abaixar mas o Mestre domina. Nessa situação vive o povo. Meu pessoal lá da cidade sabe que as coisa vão melhorar. Foi por isso que eu cortei a rede. A barriga precisa doer mesmo, quando tiver uma ferida bem grande, então todo mundo grita de vez. Pra mim, Princesa Isabel é ilusão.

Cota: Agora me lembrei do homem que um dia me convidou pra trabalhar na cidade. $\mathrm{O}$ serviço era na cama, não liguei nada e um dia o camarada abriu a boca e falou que me amava. Mas cadê coragem pra casar? Pra ser cachorro de dia e mulher de noite prefiro comer peixe aqui mesmo. Eu sei que devia ir embora, mas cadê coragem pra deixar a terra? Firmino, você cortou a rede e vai ser uma desgraça!

Firmino: Meu sofrimento ninguém vê, sou diplomado em matéria de sofrer. Meu sofrimento ninguém vê...

O diálogo acima se desenrola logo após a segunda arrancada de Firmino: como o despacho não funciona contra Aruan, ele decide retalhar a rede de pesca. É um momento de rara vulnerabilidade no discurso do malandro, que revela a Cota a sua verdadeira condição material e social na cidade - pária, paupérrimo, visado pela polícia. Por sua vez, Cota se define por um horizonte econômico muito distinto e mais amplo que o de seus conterrâneos. Isto é, a lei de extrema exploração econômica que oprime os demais pescadores não faz pressão sobre ela. Cota é emancipada, herdeira, proprietária de meios de produção, e goza de uma relativa riqueza que lhe proporcionaria alguns acessos, inclusive à cidade.

De modo que, dentro do estreito jogo econômico que opõe pescadores e o proprietário das redes, Cota conta com dois trunfos: as jangadas e o corpo. No excerto acima, mais uma vez revela-se que ela tenha disposto de seu corpo em troca de ganho (“Agora me lembrei do homem que um dia me levou pra trabalhar na cidade. O serviço era na cama [...]"). As jangadas e o corpo passam a representar dois âmbitos de natureza econômica e espacial que se cruzam através da personagem. Se as jangadas aludem à realidade extrativista primária do mundo praieiro, a província, o corpo disposto para a prostituição faz pensar, ao menos no contexto do cinema baiano desta época, impregnado de um forte espírito urbano, no lumpen citadino, na marginalidade da capital. Portanto, 
na Cota de Barravento cruzam-se as duas matrizes de representação da mulher negra de que nos falava Caymmi: a da canção praieira e a do samba urbano.

Se a ambiguidade de Firmino é condensada na figura marginal do malandro urbano, Cota, por sua vez, incorpora o correspondente feminino: a liberalidade do corpo e a autoconsciência lhe proporcionam um horizonte de ação que cobre tanto o mundo provinciano quanto a cidade. Apesar disso, Barravento dá protagonismo aos caracteres masculinos como figuras do êxodo, possíveis condutores da ação coletiva.

Dentro do processo histórico de metropolização dos espaços e aglutinamento da província pela lógica de exploração urbana, Cota é, não uma figura do êxodo, mas do exílio. Devendo "optar" entre a marginalidade urbana que a submete à exploração do corpo e a marginalidade provinciana, alheia à restrita moral praieira, se decide pela última. $\mathrm{O}$ gargalo do enredo para essa personagem é a manipulação masculina que lhe impõe o sacrifício e a loucura - Glauber dirá naquela citação inicial que ela é sacrificada para o nascimento de um homem político. Isso porque ela ainda está profundamente ligada a uma matriz narrativa que não dá centralidade e autonomia ao indivíduo feminino negro. A supererotização do seu corpo é, em última instância, a estetização de uma lógica de exclusão social, porque idealiza e acomoda os corpos negros na extremidade do processo econômico, e de forma mais acentuada para a mulher negra. 


\section{Considerações finais}

Estudar o primeiro longa-metragem de Glauber Rocha é confrontar-se com o termo "complexidade" em diversos níveis. Primeiramente, uma complexidade de produção, por conta das idas e vindas que envolveram o processo de feitura da obra, desde o argumento de Luiz Paulino dos Santos, passando pelo roteiro de Glauber Rocha e José Telles Magalhães, até uma reformulação final, mais próxima do filme que conhecemos. Essa última versão é fruto de uma mudança radical de perspectiva a partir da "descoberta" da miséria dos pescadores de xaréu no litoral não-urbanizado da Bahia, até então ignorada pelo jovem diretor.

A essa altura, Glauber Rocha vinha se impondo como um crítico entusiástico de cinema e literatura, muito atuante no ambiente intelectual neocosmopolita que orbitava em torno da recém criada Universidade de Salvador (1954). A capital baiana, embora sem o mesmo vigor industrial do Sudeste, estava em franca expansão demográfica, seguindo à sua maneira a marcha do desenvolvimentismo da República Populista, enquanto no plano da cultura acadêmica os quadros docentes da universidade eram ocupados por representantes da neovanguarda europeia: dentre os quais, Lina Bo Bardi, Koellreutter, Yanka Rudzka.

Os dois fenômenos são intelectualmente instigantes para o crítico que logo se converte em diretor de cinema: o aprofundamento de clivagens sociais históricas do Brasil em meio ao surto urbano e a absorção de concepções estéticas terceiro-mundistas por parte dos artistas que orientam sua formação.

Daí decorre uma segunda complexidade de Barravento: através de sua obra, Glauber Rocha entra em debate com um establishment da cultura brasileira que vinha se sedimentando desde os anos 1930 através da literatura regionalista, e mais especificamente, com uma certa representação das populações negras que se consagrara nos romances de Jorge Amado. Os ritos do candomblé, a performance da capoeira, o samba de roda, a Itapuã bucólica dos coqueiros e o mar caymmiano - esses signos que podem ser sintetizados como a terra, a tradição e a expressão estética da população negra, mitificados tanto pela literatura de Jorge Amado quanto por parte da produção documental de Alexandre Robatto Filho, passam a ser colocados em questão por Glauber, tendo em vista a violência do processo de metropolização da Bahia e do Brasil.

Com a necessidade de reformulação crítica dessa representação canônica que erotiza e sublima os corpos negros mas minimiza as tensões sociais que os oprimem, seu 
cinema vai em busca de uma outra verdade. E surge uma terceira complexidade de Barravento: o processo de criação de uma nova linguagem fílmica se impõe, a fragmentação da linha narrativa do cinema comercial em nome de uma forma dialética, muito inspirada na teoria do teatro épico de Bertolt Brecht, rompendo o cerco encantatório das formas da cultura popular, mas também de suas representações literárias ou eruditas. Isso tudo, por parte de um cineasta estreante, que estava testando o artifício da montagem, a movimentação e o posicionamento de câmera, em suma, começando a se apropriar dos meios de expressão e da técnica cinematográfica.

O resultado dessa experiência desemboca em uma última complexidade, apontada pelo crítico Ismail Xavier: ${ }^{147}$ é uma obra ambígua, que se por um lado encena um discurso frontal contra a alienação religiosa, por outro, na interação entre os elementos estruturais (o som, a imagem, a montagem), reafirma uma interpretação anímica do microcosmo praieiro. Isso significa que, em alguma medida, há uma força e autonomia estética no fenômeno social, na cultura negra candomblezeira, que se impõe ou se funde com o discurso revolucionário.

Vistas de perto, enquanto integrantes dessa estrutura fragmentada que é a linguagem do filme mas também, em alguma medida, como uma evidência das reformulações do enredo, as personagens de Barravento prismam a ambiguidade do conjunto. Repletas de divergências e convergências tanto internas como de umas com as outras, com seus ciclos de despertencimento, Firmino, Aruan, Naína e Cota transitam entre o dentro e o fora dos sistemas tradicionais de trabalho, da religião e da moral, tendo como uma possibilidade mais ou menos palpável a cidade.

Barravento é o único filme ligado ao Ciclo Baiano do Cinema ${ }^{148}$ a deslocar o núcleo da ação do centro urbano para um espaço periférico provinciano, no caso Itapuã. Ao fazê-lo, o longa-metragem se torna um filme que aborda o êxodo em sentido inverso: em um período de forte metropolização observa-se a crise na província que, alheia ao processo histórico desenvolvimentista, sente os efeitos do acirramento das dinâmicas de exploração, expulsando os indivíduos para a marginalidade das capitais.

147 XAVIER, Ismail. Sertão Mar: Glauber Rocha e a estética da fome. São Paulo: Duas Cidades; Editora 34, 2019

148 Apud CARVALHO, Maria do Socorro Silva. A nova onda baiana: cinema da Bahia (19581962). Salvador: EDUFBA, 2003. 
A Itapuã de Glauber Rocha é a forma agônica do paraíso utópico caymmiano, o pescador é esvaziado de seu sistema de valores e compelido para a capital em busca de aquisição de bens, mas torna-se lumpen, vivenciando a marginalidade e o anonimato sem o pano de fundo fabular do cais de Jorge Amado. O ciclo aberto por Firmino se perpetua em Aruan. A Itapuã de Glauber Rocha é um microcosmo cujo horizonte são as contradições internas do Brasil: a complementaridade entre o progresso econômico e o subdesenvolvimento, a coexistência tensa entre um espírito cosmopolita irrequieto que quer crer em uma perspectiva de futuro universalizante e a força das formas seculares da cultura local, a dinamização dos mecanismos de exploração e a permanência dos meios de produção arcaicos da província. 


\section{Referências bibliográficas}

\section{Livros, artigos, teses}

AMADO, Jorge. Mar morto. Rio de Janeiro: Record, 63ª ed., 1990.

BANDEIRA, Julio e LAGO, Pedro Corrêa do. Debret e o Brasil: obra completa, 18161831. Rio de Janeiro: Capivara, 2017.

BASTIDE, Roger. O candomblé da Bahia - rito Nagô. Trad. Maria Isaura Pereira de Queiroz. São Paulo: Companhia Editorial Nacional, 1961.

BENISTE, José. Òrun Àyié: o encontro de dois mundos: o sistema de relacionamento nagô-yorubá entre o céu e a Terra. Rio de Janeiro: Bertrand Brasil, 1997.

BENJAMIN, Walter. "Que é o teatro épico? Um estudo sobre Brecht." in Magia e técnica, arte e política: ensaios sobre literatura e história da cultura. Trad. Sergio Paulo Rouanet. São Paulo: Brasiliense, 1994.

BERNARDET, Jean-Claude. Brasil em tempo de cinema. Rio de Janeiro, Civilização Brasileira, 1967.

BOSI, Alfredo. História concisa da literatura brasileira. São Paulo: Cultrix, 2006.

BRAGA, Júlio. A pesca do xaréu: folclore e compromisso religioso. Afro-Ásia (UFBA), Salvador: CEAO/UFBA, 1970, v. 10.

BRECHT, Bertolt. "Ópera dos três vinténs" in Bertolt Brecht. Teatro Completo. Trad. Wolfgang Bader, Marcos Roma Santa, Wira Selanski. Rio de Janeiro: Paz e Terra, 1988, v.3.

CANDIDO, Antonio. "Dialética da malandragem" in O Discurso e a Cidade. São Paulo: Duas cidades, 1993. 
CASCUDO, Luís da Câmara. Dicionário do folclore brasileiro. São Paulo: Global, 2012.

CARVALHO, Maria do Socorro Silva. A nova onda baiana: cinema da Bahia (19581962). Salvador: EDUFBA, 2003.

ESCOREL, Eduardo. "Cinema: arte profana - Glauber Rocha antes de Deus e o Diabo" in Novos Estudos Cebrap, n 39, julho 1994, p. 209-221.

. "Glauber Rocha - A estrela parabólica" in Adivinhadores da água - pensando no cinema brasileiro. São Paulo: Cosac Naify, 2005, p. 55-84.

FANON, Frantz. Os condenados da Terra. Trad. José Laurêncio de Melo. Rio de Janeiro: Civilização Brasileira, 1968.

GASPAR, Eneida (org.). Cantigas de umbanda e de candomblé: pontos cantados e riscados de orixás, caboclos, pretos-velhos e outras entidades. Rio de Janeiro: Pallas Editora, 2008.

GATTI, José. Barravento: a estreia de Glauber. Florianópolis: Ed. da UFSC, 1987.

GOMES, Paulo Emílio Salles. "Perfis Baianos" in Crítica de cinema no suplemento literário. Rio de Janeiro: Paz e Terra, 1981, v.2.

GUIMARÃES, Antonio Sérgio Alfredo. “A recepção de Fanon e a identidade negra.” in Novos Estudos Cebrap, Brasil, n. 81, p. 99-114, julho de 2008.

OTSUKA, Edu. "Espírito Rixoso: para uma reinterpretação das Memórias de um sargento de milícias." in Revista do Instituto de Estudos Brasileiros, Brasil, n. 44, p. 105124, fev. 2007.

NUNES, Raquel Pereira Alberto. “O Barravento de Luiz Paulino dos Santos”. in Revista Brasileira de História das Religiões, Brasil, v. II, p. 131-153, 2009. 
IPHAN. Samba de roda do Recôncavo Baiano. Dossiê IPHAN 4: Ministério da Cultura, 2007.

JAMESON, Frederic. "Periodizando os anos 1960" in HOLLANDA, Heloísa Buarque de. (org). Pós-modernismo e política. Trad. César Brites e Maria Luiza Borges. Rio de Janeiro: Rocco, 1992.

MEDEIROS, José. Candomblé. São Paulo: Instituto Moreira Salles, 2009.

PRANDI, Reginaldo. Mitologia dos Orixás. São Paulo: Companhia das Letras, 2001.

PRUDENTE, Celso. Barravento: o negro como possível referencial estético do Cinema Novo de Glauber Rocha. São Paulo: Editora Nacional, 1995.

REBECHI JUNIOR, Arlindo. Glauber Rocha, ensaísta do Brasil. Tese (Doutorado em Literatura Brasileira) - Faculdade de Filosofia, Letras e Ciências Humanas, Universidade de São Paulo, São Paulo, 2011.

. "Glauber Rocha e a crítica de cinema no Diário de Notícias: periferia e resistência." in Contemporânea: Revista de Comunicação e Cultura, Brasil, v.11, n.03, p.522-534, dez. 2013.

RISÉRIO, Antonio. Avant-garde na Bahia. São Paulo: Instituto Lina Bo e P.M. Bardi, 1995.

Caymmi: uma utopia de lugar. São Paulo: Perspectiva, 1993.

(Debates; v.253)

A utopia brasileira e os movimentos negros. São Paulo: Editora 34, 2012.

ROCHA, Glauber. Cartas ao mundo (org. Ivana Bentes). São Paulo: Companhia das Letras, 1997. 
Revisão crítica do cinema brasileiro. São Paulo: Cosac \& Naify, 2003.

. Revolução do Cinema Novo. São Paulo, Cosac \& Naify, 2004.

. Roteiros do Terceyro Mundo (org. Orlando Senna). Rio de Janeiro:

Alhambra/Embrafilme, 1985.

ROSENFELD, Anatol. Brecht e o teatro épico (org. Nanci Fernandes). São Paulo: Perspectiva, 2012.

SANTOS, Milton. O centro da cidade de Salvador: estudo de geografia urbana. São Paulo: Editora da Universidade de São Paulo; Salvador: EDUFBA, 2008.

A cidade nos países subdesenvolvidos. Rio de janeiro: Ed. Civilização

Brasileira, 1965.

SCHWARZ, Roberto. "Pressuspostos, salvo engano, da Dialética da Malandragem" in Que horas são? - ensaios. São Paulo: Companhia das Letras, 1987, pp. 129-155.

. "Fim de século" in Sequências brasileiras: ensaios. São Paulo:

Companhia das Letras, 1999, pp.155-162.

SILVA, Humberto Pereira da. Glauber Rocha: Cinema, Estética e Revolução. São Paulo: Paco Editorial, 2016.

SILVA, Vagner Gonçalves da. "Exu do Brasil: tropos de uma identidade afro-brasileira nos trópicos". Revista De Antropologia, Brasil, n. 55, p.1085-1114, jul. 2013.

STAM, Robert. Multiculturalismo tropical, uma História Comparativa da raça na cultura e no cinema brasileiros. Trad. Fernando S. Vugman. São Paulo: Edusp, 2008.

TACCA, Fernando Cury. Imagens do sagrado: entre Paris Match e O Cruzeiro. Campinas: Ed. da Unicamp/Imprensa Oficial do Estado de São Paulo, 2009. 
TAVARES, Odorico. Bahia: imagens da terra e do povo. Rio de Janeiro: Civilização Brasileira, 1964.

VERGER, Jean-Pierre. Retratos da Bahia: 1946-1952. Salvador: Corrupio, 2002.

Orixás: deuses iorubás na África e no Novo Mundo. (trad. Maria Aparecida de Nóbrega). Salvador: Corrupio, 2002.

XAVIER, Ismail. Sertão mar: Glauber Rocha e a estética da fome. São Paulo: Duas Cidades; Editora 34, 2019.

\section{Periódicos:}

"Barravento exportará os encantos da Bahia para as telas do mundo". Jornal da Bahia, Salvador (BA), 10 março 1959.

“Barravento". Visão, Salvador (BA), 07 dezembro 1960.

"Barravento" chega ao fim: cresce o cinema na Bahia. Diário de Notícias de Salvador, Salvador (BA), 18 e 19 dezembro 1960, $3^{\circ}$ Caderno.

MACIEL, Luiz Carlos. “Contribuição à sua análise”, Diário de Notícias, Salvador (BA), 03 junho 1962, Suplemento.

PORTELA, Geraldo. "Um gole de política”, Diário de Notícias, Salvador (BA), 03 junho 1962, Suplemento.

ROCHA, Glauber, em Walter Lima Júnior, "Barravento no cinema brasileiro". Correio da Manhã, Rio de Janeiro (RJ), 17 abril 1962.

ROCHA, Glauber. "Experiência Barravento: confissão sem moldura". Diário de Notícias de Salvador, Salvador (BA), 25-26 dezembro 1960. 
SENNA, Orlando. "Em busca do ritmo - I”, Diário de Notícia, Salvador (BA), 03 junho 1962, Suplemento.

. "Barravento". Diário da Noite, (BA), 28 maio 1962, Show Business.

VIANY, Alex. "Um problema de comunicação", Diário de Notícias, Salvador (BA), 03 junho 1962, Suplemento.

\section{Filmes:}

BARRAVENTO. Direção: Glauber Rocha. Bahia: Iglu Filmes, 1961. 2 DVD (80 min.), p\&b.

BAHIA de Todos os Santos. Direção: Trigueirinho Neto. Bahia: Ubayara Filme, 1960. 1 Filme (102 min.), p\&b.

DEUS e o diabo na terra do Sol. Direção: Glauber Rocha. Rio de Janeiro: Copacabana Filmes, 1964. 1 Filme (120 min.), p\&b.

ENTRE o mar e o tendal. Direção: Alexandre Robatto Filho. Bahia: Diretoria do Arquivo e Divulgação e Estatística, 1953. 1 curta metragem documentário (22 min.), p\&b.

XARÉU. Direção: Alexandre Robatto Filho. Bahia: 1954. 1 curta metragem documentário (8 min.), p\&b.

VADIAÇÃO. Direção: Alexandre Robatto Filho. Bahia: 1954. 1 curta metragem documentário (8 min.), p\&b.

Disponível em: https://www.youtube.com/watch?v=zYH7WDoUdOE e https://www.youtube.com/watch?v=ObGj2e2bsAc. Acesso em 17 julho 2020.

OS FILMES que eu não fiz: Alexandre Robatto Filho, Pioneiro do Cinema na Bahia. Direção: Petrus Pires. Bahia: Estúdio Sonia Robatto e Iglu Filmes, 2012. 1 curta metragem (26 min.), colorido. 
Disponível em: https://www.youtube.com/watch?v=_S8ifaFe9yE. Acesso 17 de julho 2020. 